WOLF EJZENBERG

\title{
Desarmamento Nuclear
}

Dissertação apresentada à Banca Examinadora do Programa de Pós-Graduação em Direito, da Faculdade de Direito da Universidade de São Paulo, como exigência parcial para obtenção do título de Mestre em Direito, na área de concentração de Direito Internacional, sob a orientação do Professor Associado Dr. Geraldo Miniuci Ferreira Junior.

Versão corrigida em 18/05/2015. A versão original, em formato eletrônico (PDF), encontra-se disponível na CPG da Unidade, para ser encaminhada ao Serviço de Biblioteca e Documentação da Faculdade de Direito da USP.

UNIVERSIDADE DE SÃO PAULO

FACULDADE DE DIREITO

São Paulo - SP

2015 
Nome: EJZENBERG, Wolf

Título: Desarmamento nuclear

Dissertação apresentada à Faculdade de Direito da Universidade de São Paulo para a obtenção do título de Mestre em Direito.

Aprovado em:

Banca examinadora

Prof. Dr.

Instituição:

Julgamento: Assinatura

Prof. Dr. Instituição:

Julgamento: Assinatura:

Prof. Dr. Instituição:

Julgamento: Assinatura: 
Para o meu Amor 


\section{AGRADECIMENTOS}

A elaboração deste trabalho apenas se tornou possível depois de um primeiro ato de confiança, por parte do Professor Geraldo Miniuci Ferreira Junior, que ao me aceitar como orientando propiciou uma das experiências mais intensas da minha vida, que acabou se refletindo de modo muito importante em diversos aspectos pessoais, razão pela qual a ele dedico esse primeiro agradecimento.

Essa oportunidade, entretanto, nunca teria sido viável sem a parceria da minha esposa, eterna namorada, Andréa, que me incentivou a enfrentar essa empreitada e, mais importante, compartilhou as alegrias, ansiedades, incertezas, angústias, epifanias e uma série de outras sensações vividas ao longo desse período, sempre repetindo uma certeza que possuía sobre a conclusão do trabalho, especialmente nos meus momentos de questionamento e dúvidas, impedindo que prevalecessem. Por esse apoio, e por sua compreensão no sacrifício de planos igualmente importantes para nós, e, de horas, dias, finais de semana, feriados e viagens que não aconteceram para possibilitar a pesquisa, agradeço imensamente, algo que espero poder retribuir na mesma moeda.

De fundamental importância foi também o apoio incondicional de meus pais, Helena e Sergio, a quem agradeço profundamente pela torcida irrestrita, e por terem propiciado todo um caminho de anos até esse momento. Especialmente, sou muito grato pelo carinho sempre reconfortante das horas difíceis. Exemplos de pais a serem seguidos.

Nesse grupo de torcedores entusiastas, agradeço aos meus irmãos Fernanda, Renata, Diogo e Bruno, que constantemente me ajudavam a reunir forças adicionais, fosse em conversas para relaxar, ou em cervejinhas terapêuticas essenciais nesse processo todo. Não poderia deixar de incluir aqui meu sobrinho Rafael, que ainda nem sabe como suas risadas foram importantes para desanuviar o espírito em momentos de cansaço.

Agradeço ainda a torcida intensa dos meus sogros, Felícia e Nilson, e da Carine e do Guilherme, tantas vezes ouvindo 'nãos' para convites de jantares e saraus, os quais eram sempre respondidos com compreensão e tolerância. 
Devo um agradecimento especial ao Professor Masato Ninomiya, cujo enorme respeito que possui no país e no Japão viabilizou minha participação no programa de verão na Universidade de Hiroshima, em 2013, oportunidade ímpar de visitar lugares e conhecer pessoas que testemunharam o ataque nuclear, reforçando a convicção do acerto sobre o tema escolhido para a pesquisa.

Não poderia deixar de agradecer ao Ernesto Tzirulnik, pela amizade, pelo incentivo constante para me aprimorar, e, mais importante, pela tolerância e compreensão com ausências temporárias, apoio fundamental para que pudesse conciliar a pesquisa com os afazeres da advocacia. Sem esse suporte, esse caminho não teria sido percorrido.

De todos os amigos, sem dúvida alguma aquele que teve papel essencial para a elaboração deste trabalho foi o Paulo Piza, mentor e colaborador intenso, pacientemente discutindo e rediscutindo ideias, indicando e presenteando livros importantes, sempre se dispondo a reuniões, mesmo em feriados e finais de semana. Esse tipo de ajuda voluntária, desprendida, e tão fundamental, é difícil, se não impossível, de retribuir.

Aos meus amigos do escritório, agradeço pela tranquilidade que me passaram ao compreenderem meus afastamentos, e, mesmo assoberbados, seguirem me incentivando. A amizade de todos é impagável. Agradeço a todos eles, Maurício Silveira, Carlos Leal, Tiago Moraes Gonçalves, Jéssica Bastos, Léa Vidigal, Oberdan, Jacileide, Raimunda, Ana Luisa, Daniela, Gabriela e Miriam.

Não poderia deixar de registrar o agradecimento a alguns amigos tão importantes na minha vida, tempero que torna tudo mais agradável, como a galera da IGESP, a Dada, o Guga, o André, o Zé Luis, o Weisz e a Selma. A todos, um abraço do amigo ausente.

Devo ainda reconhecer a importantíssima ajuda da Rosie, da Ieda e do Roberto na reta final, sem a qual seria muito difícil concluir o trabalho.

Por fim, devo um agradecimento a todos da equipe de Judô da Hebraica, na pessoa de meu Sensei Edison Minakawa, por terem propiciado meio tão importante para manter a sanidade durante os últimos meses da pesquisa. 
"REST IN PEACE, FOR WE SHALL NOT REPEAT THE EVIL"

Tadayoshi Saika 


\section{RESUMO}

EJZENBERG, W. Desarmamento nuclear. 2015. 289 f. Dissertação (Mestrado) Faculdade de Direito, Universidade de São Paulo, São Paulo, 2015.

Esta dissertação aborda o tema do desarmamento nuclear, numa tentativa de compreender a dinâmica pela qual o desarmamento se opera em nível internacional. A limitação à questão nuclear permite descrever o aparato jurídico-institucional existente para obter o abandono das armas nucleares e, ao mesmo tempo, identificar quais são e como se manifestam os obstáculos para sua concretização. A pesquisa toma como referência inicial o ensaio À Paz Perpétua, de Immanuel Kant, especialmente por suas proposições para sobrepor imperfeições da realidade atual por meio de uma evolução pautada pela razão e pela moral. No projeto kantiano, o filósofo acaba concebendo bases que podem ser úteis como referência para o fortalecimento gradual do desarmamento nuclear. A pesquisa contextualiza, assim, o surgimento das armas nucleares e a evolução da era nuclear, procurando identificar em que medida sua existência é contrária a um convívio harmonioso internacionalmente. Por se tratar de um trabalho jurídico, a parte central da dissertação é composta por detalhada análise dos tratados, convenções, organismos, resoluções e decisões judiciais internacionais relacionados ao controle e tentativa de banimento das armas nucleares. A avaliação crítica desses mecanismos jurídicos permite verificar um processo de evolução gradual, semelhante à que é concebida no ensaio de Kant para a obtenção da Paz Perpétua. Assim, apesar de representarem passos concretos rumo à meta do desarmamento nuclear, sendo interessante verificar como esses passos se retroalimentam fomentando bases mais sólidas para a busca desse fim, eles ainda são marcados por graves imperfeições e fragilidades. Com o intuito de compreender mais adequadamente os obstáculos enfrentados para o aprimoramento e pleno funcionamento do aparato jurídico desenvolvido em torno dessa problemática, a pesquisa é complementada pela análise de questões atinentes às Relações Internacionais, por meio da utilização de diversas referências bibliográficas e análise de contextos políticos específicos, possibilitando melhor compreensão de como os elementos políticos interferem para a plena consecução das normas estabelecidas internacionalmente. Essa compreensão é essencial para possibilitar passos adicionais na busca do banimento completo das armas nucleares.

Palavras-chave: Desarmamento nuclear. Kant. Direito Internacional. Relações Internacionais. 


\begin{abstract}
EJZENBERG, W. Nuclear Disarmament. 2015. 289 f. Dissertação (Mestrado) Faculdade de Direito, Universidade de São Paulo, São Paulo, 2015.

This dissertation discusses nuclear disarmament in an attempt to understand the dynamics by which it operates internationally. Limiting its scope to the nuclear issue makes it possible to describe the existing legal and institutional apparatus required to forgo nuclear weapons and, at the same time, identify what are and how behave the obstacles posed against its accomplishment. The research uses as its initial reference Immanuel Kant's essay Perpetual Peace, particularly its propositions about overcome shortcomings of the present by means of an evolution guided by morals and reason. Kant establishes foundations that can be useful to gradually strengthen the means to bring about full nuclear disarmament. Thus, this research contextualizes the emergence of nuclear weapons and the ascent of the nuclear age, seeking to assess to what extent these weapons are deleterious to a peaceful international environment. The central part of the dissertation is a detailed evaluation of the international treaties, conventions, organisms, resolutions and judicial decisions related to nuclear non-proliferation and disarmament, which allows to verify a gradual evolution similar to the one conceived by Kant in order to obtain Perpetual Peace. Despite these developments can be interpreted as concrete steps towards the nuclear disarmament goal, they are still imperfect and fragile. Aiming to understand properly what are the obstacles against theirs full effectiveness, it was also developed an analysis regarding international relations and politics, basing upon relevant authors and specific political backgrounds, allowing a better comprehension of the interferences presented against the total accomplishment of the international norms. This understanding is essential to allow additional steps in pursuit of the complete proscription of nuclear weapons.
\end{abstract}

Keywords: Nuclear disarmament. Kant. International Law. International Relations. 


\section{SUMÁRIO}

\section{Introdução $\cdot 10$}

Parte I: Projeto kantiano À Paz Perpétua como baliza referencial do desarmamento nuclear $\cdot 23$

Capítulo 1. À Paz Perpétua e o desarmamento nuclear · 24

Capítulo 2. Atual estágio da questão nuclear para fins bélicos · 40

Capítulo 3. Utilidade do projeto À Paz Perpétua como elemento para descrever o desarmamento nuclear · 66

Parte II: Análise crítica dos elementos que compõem o regime de não proliferação e desarmamento nuclear $\cdot 83$

Capítulo 1. O início da era nuclear $\cdot 84$

Capítulo 2. O Tratado de Não Proliferação de Armas Nucleares · 101

Capítulo 3. Os dois outros pilares - a AIEA e o Conselho de Segurança da ONU · 127

Capítulo 4. As zonas livres de armas nucleares · 143

Capítulo 5. Elementos complementares $\cdot 154$

Parte III: As armas nucleares à luz dos princípios e normas aplicáveis aos conflitos armados - precedente jurisprudencial $\cdot 184$

Capítulo 1. Desenvolvimento das normas aplicáveis aos conflitos armados - evolução racional para a pacificação $\cdot 185$

Capítulo 2. Análise crítica da opinião consultiva da Corte Internacional de Justiça, de 1996, sobre a ilegalidade do uso ou da ameaça do uso de armas nucleares · 206

\section{Parte IV: Desarmamento dificultado pela política internacional $\cdot 226$}

Capítulo 1. O comportamento da principal potência como principal obstáculo $\cdot 227$

Conclusão $\cdot 253$

Referências $\cdot 266$ 


\begin{abstract}
"Se existisse ao menos um ensinamento em que pudéssemos acreditar! Todas as coisas se contradizem, passam umas ao lado das outras sem se tocar, e em parte alguma existe a certeza. A tudo se pode conferir um dado significado ou o significado contrário. Podemos apresentar a história universal como um processo de evolução e progresso, e considerá-la ao mesmo tempo decadência e absurdo. Não existirá a verdade?"
\end{abstract}

Hermann Hesse ${ }^{1}$

\title{
INTRODUÇÃO
}

A indagação do personagem criado por Herman Hesse diante das dúvidas sobre como compreender a história universal acaba ilustrando fielmente questões que se levantam contra o ideal kantiano manifestado no projeto À Paz Perpétua ${ }^{2}$.

Kant propôs a construção de um ideal pautada por um processo histórico evolutivo permeado pela razão, culminando na preponderância da moral como valor, que conduziria o direito e a política para a consolidação das bases sobre as quais se poderia estabelecer a paz perpétua. Contra essa concepção há uma série de críticos que, ao testemunharem atrocidades e retrocessos em eventos como as guerras mundiais ou, mais recentemente, os conflitos étnicos na África e nos Balcãs, veem apenas a frustração da ideia de uma evolução.

Essa crítica, contudo, desconsidera que Kant não ignora as vicissitudes da História, marcada por esse tipo de acontecimentos que realmente não inspiram confiança numa evolução. É por essa razão que o filósofo não propõe uma obra feita, mas as pedras fundamentais sobre as quais seria possível construí-la. Do mesmo modo, essa crítica ignora

\footnotetext{
1 HESSE, Hermann. O jogo das contas de vidro. Tradução de L. A. Viotti e F. V. de Souza. 14. ed. São Paulo: Record, 2003, p. 85.

2 KANT, Immanuel. À Paz Perpétua. Tradução de M. A. Zingano. São Paulo: L\&PM Editores, 1989.
} 
que, segundo a teoria do próprio filósofo, se não houvesse nenhuma evolução por se verificar, nenhum amadurecimento do direito internacional e das relações internacionais, haveria uma sociedade estática, anti-histórica: “A própria natureza do homem e da sociedade faz com que, na verdade, a busca do fim e da perfeição só possa ser indefinida e imperfeita. Uma humanidade virtuosa seria estática, propriamente anti-histórica.”3

O próprio Direito Internacional é, de maneira similar, também confrontado com questionamentos e críticas sobre sua efetividade e, como consequência, sobre sua própria existência e validade ${ }^{4}$. Esse ceticismo decorre da compreensão de que não basta às normas serem existentes e válidas num dado ordenamento caso desprovidas de efetividade, circunstância que impediria a consecução do fim a que são destinadas ${ }^{5}$.

Aqueles que se alinham a esses questionamentos argumentam que, por carecer de organismos supranacionais dotados de poderes suficientes para a imposição de sanções contra aqueles que descumprem as normas internacionais, o Direito Internacional é muito mais um instrumento a ser utilizado no tabuleiro da política internacional do que um ramo jurídico propriamente dito ${ }^{6}$.

Cassese, apesar de não concordar, reconhece essas críticas sobre as fragilidades do Direito Internacional, muitas vezes submetido ao jogo político das relações de poder, afirmando que

\begin{abstract}
as técnicas internacionais para induzir observância ao direito internacional, assim como para a aplicação de sanções, são fracas e rudimentares. Segue daí que se um Estado que desrespeite uma norma internacional é poderoso ou protegido por um país poderoso, ele pode muito facilmente estar certo da impunidade ${ }^{7}$.
\end{abstract}

3 MELLO, Sérgio Vieira de. História filosófica e História real: atualidade do pensamento político de Kant. In: MARCOVITCH, Jacques (Org.). Sérgio Vieira de Mello - pensamento e obra. São Paulo: Edusp / Saraiva, 2004, p. 43.

4 AKEHURST, Michael. Introdução ao Direito internacional. Tradução de F. Ruivo. Coimbra: Almedina, 1985, p. 1-6. Referido autor não comunga dessas críticas contra o Direito Internacional, mas expõe, de uma maneira interessante e objetiva, as razões que permitem afastá-las.

5 Conferir REALE, Miguel. Lições preliminares de Direito. 24. ed.. São Paulo: Saraiva, 1999, p. 112: "Aqui fazemos uma pergunta: basta a validade técnico-jurídica para que a norma cumpra a sua finalidade?".

6 DUPUY, René-Jean. O Direito internacional. Tradução de Clotilde Cruz. Coimbra: Almedina, 1993, p. 6. 7 CASSESE, Antonio. International Law in a Divided World. Oxford: Oxford University, 1986, p. 16. Ver ainda BYERS, Michael. A lei da guerra - direito internacional e conflito armado. Rio de Janeiro: Record, 
Essa concepção decorre da aceitação da prática entre os Estados de privilegiar as relações de poder $^{8}$ com enfoque na "política internacional, distinto daquele que se nos depara em direito internacional, pois se neste tem ênfase o aspecto humanitário, naquele domina o pragmatismo, o realismo (Realpolitik)" ${ }^{9}$.

O resultado dessa concepção, segundo Amaral Junior ${ }^{10}$, impede que as regras do direito internacional sejam dotadas de coerência e consistência em relação ao seu cumprimento, sujeitando-se às conveniências dos Estados de respeitarem ou denunciarem quaisquer tratados internacionais:

Os Estados podem perseguir quaisquer fins, independentemente de restrições morais e jurídicas, que só atuam no plano doméstico. O seu comportamento é ditado por razões de conveniência e oportunidade, de tal sorte que os acordos devem ser mantidos sempre que forem úteis ou convenientes e rompidos quando contrariarem o interesse das partes.

Partindo-se dessa premissa, a lógica jurídica acabava se relativizando em meio aos processos de tomada de decisão dos Estados, invariavelmente avaliados em termos estratégicos políticos ${ }^{11}$.

Dessa forma, embora sem implicar necessariamente o descumprimento de normas, acabava sendo evidenciada a fragilidade mesmo dos mais complexos e elaborados institutos jurídicos que, num primeiro momento, haviam sido celebrados como importantes conquistas para a consolidação de uma efetiva ordem internacional supranacional, como prova a inércia do Conselho de Segurança da ONU em função da bipolaridade entre os EUA e a ex-URSS durante a Guerra Fria:

Até que o Iraque invadisse o Kuwait, o Conselho de Segurança exerceu de maneira restrita sua autoridade prevista no Capítulo VII. Na realidade,

2007, p. 192, e DALLARI, Dalmo de Abreu. Elementos de Teoria geral do Estado. 20. ed.. São Paulo: Saraiva, 1998, p. 264: “a regulação jurídica seria apenas aparente, pois os Estados mais fortes dispõem de meios para modificar o direito quando isso lhes convêm".

8 A respeito da concepção das relações de poder, conferir WIGHT, Martin. A política do poder. Tradução de C. S. Duarte. Brasília: Editora UnB, 1985, p. 20.

9 ACCIOLY, Hildebrando; NASCIMENTO E SILVA, Geraldo E. do; CASELLA, Paulo Borba. Manual de Direito Internacional Público. 16. ed. São Paulo: Saraiva, 2008, p. 815.

10 AMARAL JUNIOR, Alberto do. O direito de assistência humanitária. São Paulo: Renovar, 2003, p. 10.

11 GONÇALVES, Alcindo; FONTOURA COSTA, José Augusto. Governança global e regimes internacionais. São Paulo: Almedina, 2011, p. 161. 
apenas num único caso, envolvendo a Coreia, o Conselho efetivamente adotou ações concretas contra sua agressão, e isso apenas foi possível devido à fortuita circunstância de o representante soviético ter se retirado previamente em protesto contra a decisão do Conselho de considerar a China Nacionalista (anticomunista) como a legítima representante chinesa no Conselho ${ }^{12}$.

Essa concepção do Direito Internacional era vítima de uma construção fundamentada sobre a ideia da ilimitada soberania dos Estados, que se colocava como um obstáculo quase intransponível para que o Direito pudesse exercer papel prescritivo contra uma realidade marcada apenas por teorias que descreviam e justificavam as relações políticas.

Tal percepção, contudo, não poderia ser interpretada de modo a impedir um processo contínuo de tentativas de aprimoramento não apenas normativo e institucional, mas, sobretudo, principiológico e conceitual, para a afirmação do Direito Internacional.

A alternativa seria a resignação com o que representaria um caráter estático e antihistórico da humanidade referido mais acima, com a solidificação de dados perenizando problemas que, necessariamente, devem ser enfrentados e resolvidos por meio de uma elaboração continuada.

A partir das Guerras Mundiais do século XX, pode-se considerar que houve uma guinada dessa realidade, a qual o já citado Cassese descreve por suas importantes inovações, que tendiam a moldar as regras internacionais e os sistemas legais domésticos, tais como a criação de instituições globais, a reivindicação de maior respeito aos sujeitos de direito internacional, as severas restrições ao uso da força e o crescente movimento de defesa dos direitos humanos ${ }^{13}$.

Ainda segundo o autor, essa mudança demanda grande atenção para que as regras jurídicas fomentadas num momento mais auspicioso para pretensões elevadas não se tornem letra morta. Ele identifica importante foco de tensão que se verifica plenamente na atualidade:

12 MURPHY, John F. Force and Arms. In: SCHACHTER, Oscar; JOYNER, Christopher. C. (Eds.). United Nations Legal Order. Cambridge: American Society of International Law, 1995, p. 279. v. 1. Tradução livre do original em inglês.

13 CASSESE, Antonio. International Law in a Divided World. Oxford: Oxford University, 1986, p. 400. 
Assim como uma macieira não se torna uma figueira apenas porque alguém colocou uma placa sobre ela determinando essa mudança, as relações sociais efetivas entre os Estados não se alterarão simplesmente por uma reclassificação formal. $\mathrm{O}$ direito internacional tradicional constituiu "realisticamente" um corpo de regras legais, refletindo o modo pelo qual as potências se relacionavam. [...] Com a mudança para o "modelo da Carta [das Nações Unidas]", a distância entre a real posição dos Estados na comunidade mundial e as demandas da maioria frágil se materializou de maneira muito acentuada. [...] A lei se tornou mais idealista e menos realista ${ }^{14}$.

Essa alteração foi significativa e rompeu com uma concepção clássica do Direito Internacional, que poderia ser considerada imutável porque qualquer alteração implicaria uma revisão de conceitos basilares, como o da soberania irrestrita. A irresignação com uma realidade inaceitável, cuja falência já havia sido colocada à prova nos dois conflitos mundiais, impunha a defesa de mudanças com características idealistas, ou mesmo utópicas, indispensáveis para o amadurecimento e evolução das normas e instituições internacionais. Somente

a partir de patamares mais ou menos consistentes de implantação dos princípios, normas e instituições internacionais e operacionalidade funcional destes, pode-se acrescentar a busca, a dimensão utópica, almejando o progresso e a melhoria dessa "realidade" que exista, nem sempre seja desejável, por anseio ou projeto, que mesmo que não exista (ou nem sequer possa existir), ao menos é desejável e digno de se buscar como propósito ${ }^{15}$.

De acordo com essas mudanças, pode-se afirmar que houve, especialmente na segunda metade do século XX, crescente evolução do Direito Internacional tanto em termos horizontais, ou seja, com uma ampliação dos Estados que se sujeitavam a ele e suas principais iniciativas normativas e institucionais, quanto verticais, a partir de temas regulados e mecanismos institucionais para sua implantação e aplicação de sanções em caso de descumprimento. Trata-se de uma virada notável porque, "na medida em que se

14 CASSESE, Antonio. International Law in a Divided World. Oxford: Oxford University, 1986, p. 400.

15 ACCIOLY, Hildebrando; NASCIMENTO E SILVA, Geraldo E. do; CASELLA, Paulo Borba. Manual de Direito Internacional Público. 16. ed. São Paulo: Saraiva, 2008, p. 881-882. 
reconheceu a sujeição às normas, fortalecendo-se o Direito, esvaiu-se a consistência conceitual da soberania como um poder absoluto, que não reconheceria limites" ${ }^{16}$.

Esse contexto foi marcado pela identificação de uma nova necessidade premente de mudanças posta para os Estados, a do desarmamento internacional, que se tornou preocupação de primeira ordem diante do temor causado pelo testemunho dos ataques atômicos contra Hiroshima e Nagasaki. As armas nucleares subverteram os princípios jurídicos aplicáveis à guerra clássica ao revelarem que os conflitos, a partir dali, facilmente atingiriam pessoas não envolvidas por eles ${ }^{17}$, tendo seu uso tornado a questão de como se imporem restrições aos meios de se fazer guerra, tema tratado de modo incipiente no foro internacional desde o século XIX ${ }^{18}$, uma preocupação central ${ }^{19}$.

Contudo, apesar do reconhecimento da terrível ameaça decorrente das armas nucleares, a luta contra elas inseriu-se no contexto complexo da relação de tensão entre o Direito Internacional Contemporâneo, que tende a submeter os Estados a um regime jurídico gradativamente mais propositivo e efetivo, e as heranças do período clássico em que prevaleciam os interesses individuais das nações mais poderosas.

Mesmo com as notáveis evoluções instituídas com o modelo da Carta de São Francisco, o modelo antigo remanesceu porque o novo não conseguiu suplantá-lo integralmente, pela simples razão de que o sistema internacional ainda permaneceu assente principalmente sobre Estados nacionais. O novo padrão foi sobreposto a essa realidade, o que explica a permanência de tantos traços do período anterior, "relíquias de uma era que em diversas ocasiões ressurgem e demonstram sua força poderosa" 20.

A dicotomia entre os dois padrões do Direito Internacional identificados por Cassese representa um enorme obstáculo para a obtenção do ideal do desarmamento, uma vez que o peso atribuído ao poderio bélico dos Estados como elemento de afirmação e respeito internacional talvez represente uma das características mais marcantes das "relíquias de uma era passada", que, ao ser confrontada, reage e demonstra sua força quando se

16 SALIBA, Aziz Tuffi. Conselho de Segurança da ONU - sanções e limites jurídicos. Curitiba: Juruá, 2008, p. 98.

17 MEIRA MATTOS, Adherbal. Direito internacional público. Rio de Janeiro: Renovar, 1996, p. 461.

18 Uma breve contextualização dessa evolução do direito aplicável aos conflitos armados será exposta no capítulo 1, da terceira parte deste trabalho.

19 CASSESE, Antonio. International Law in a Divided World. Oxford: Oxford University, 1986, p. 64.

20 Ibidem, p. 400-407. 
impedem aprovações de normas mais amplas, ou mesmo quando se verifica contumaz desrespeito a normas aprovadas.

Nesse sentido, para se enfrentarem esses obstáculos, a construção do desarmamento internacional poderia ser inserta como "ideia reguladora", o desarmamento como meio de construção de uma realidade em que esse comportamento pautado por jogos de interesses seria gradativamente substituído pelas bases para se alcançar a paz, um fio condutor para se atingir uma realidade futura idealizada, uma utopia balizadora da conduta moral e política dos Estados.

Pensando-se em uma "ideia reguladora" ${ }^{21}$ que paute as condutas humanas, um caminho de construção, é possível verificar conexões entre o desarmamento internacional e conceitos e propostas relevantes do projeto de Kant para a paz perpétua, que pode ser útil ao fornecer elementos significativos para se pensar um sistema específico do Direito Internacional do Desarmamento ${ }^{22}$. No seu ideal pela busca de uma ordem cosmopolita, que se coloca como uma terceira dimensão do arranjo jurídico, ao lado do direito interno e do direito internacional, por ele denominado direito das gentes, Kant acaba desenvolvendo o que poderia oferecer as bases a serem utilizadas para a construção de um Direito Internacional do Desarmamento, como será observado na primeira parte desta dissertação.

Conforme Casella $^{23}$, a referência à visão kantiana não é vazia; eventuais contratempos em sua implantação não invalidam seu quadro conceitual, sendo que o ideal que defende, mesmo que ainda não na prática, deve ser mantido ao menos como um

21 ARENDT, Hannah. Lições sobre a filosofia política de Kant. Tradução de André Duarte de Macedo. Rio de Janeiro: Relume-Dumará, 1993, p. 96: "É em virtude dessa ideia da humanidade presente em cada ser humano único que os homens são humanos, e podem ser chamados de civilizados ou humanos à medida que essa ideia torna-se o princípio não apenas de seus juízos, mas de suas ações. [...] O imperativo categórico da ação, por assim dizer, poderia ser desse modo enunciado: aja sempre de acordo com a máxima através da qual esse pacto original possa atualizar-se em uma lei geral. É desse ponto de vista, e não apenas do amor à paz, que o tratado À paz perpétua foi escrito". Sempre importante lembrar a demonstração na obra de Celso Lafer, A reconstrução dos direitos humanos - um diálogo com o pensamento de Hannah Arendt (São Paulo: Companhia das Letras, 1988), de como o pensamento de Arendt foi influenciado por Kant.

22 Por não se tratar da finalidade do presente trabalho, não se irá aqui aprofundar qualquer estudo sobre sistemas, até que ponto é possível compreendê-los como tais, suas características e traços distintivos. Para um aprofundamento no tema, contudo, conferir LOSANO, Mario G. Sistema e estrutura no Direito. Tradução de C. A. Dastoli. São Paulo: Martins Fontes, 2008.

23 CASELLA, Paulo Borba. Pax perpetua - a Review of the Concept from the Perspective of Economic Integration. In: CASELLA, Paulo Borba (Coord.). Dimensão internacional do Direito - Estudos em homenagem a G. E. do Nascimento e Silva. São Paulo: LTr, 2000, p. 72-74, tradução livre do original em inglês. 
parâmetro, já que "o desastre deve ser experimentado para propiciar que seu oposto seja avaliado e defendido".

Não se desconhecem as inúmeras críticas que o projeto kantiano sofreu por seu viés idealista, utópico, considerado até irrealizável ${ }^{24}$, sendo notável verificar que, mesmo nesse aspecto, verificam-se semelhanças com o ideal do desarmamento. Também no que toca ao desarmamento, as mesmas críticas sobre ser irrealizável, ou possuir pretensão quimérica, são recorrentes: "A luta pelo desarmamento e controle de armas no âmbito internacional é quase sempre a história de fracassos ou, quando muito, de meias vitórias ${ }^{25}$."

Apesar dessas críticas, contudo, não se pode ignorar sua atualidade e, mais ainda, sua extrema relevância. As dificuldades inerentes ao desarmamento, desse modo, não podem determinar seu abandono, sob pena de se cristalizar uma realidade que não permite ser considerada adequada a um convívio internacional harmonioso e pacífico.

Tanto é assim que, a despeito dessas características que polemizam o tema, há dados concretos que levam a reconhecer no desarmamento elementos efetivos de normatização e institucionalização internacional, com mecanismos próprios de implantação e efeito vinculante, que, por sua vez, acabam servindo de base para a elaboração de novas iniciativas, aprimorando o aparato normativo-institucional do desarmamento e encetando uma gradativa mobilização internacional que elenca valores e objetivos a serem atingidos.

Esta dissertação lida com o tema do desarmamento, limitando-se ao subcampo do desarmamento nuclear, já que o objetivo principal da pesquisa é compreender a dinâmica em que se verifica o desarmamento internacional. Assim, ao circunscrever a análise à questão nuclear, torna-se mais palpável a tentativa de descrição de qual é o aparato atualmente existente para sustentar e defender a luta pelo abandono desse tipo de armamento e, mais importante, a tentativa de identificar quais são os obstáculos que impedem sua concretização e como eles se manifestam.

Ao lado dessas questões metodológicas, o corte temático é essencial para que não se perca de vista a finalidade da pesquisa e se evite que esta se converta num tratado sobre o

24 LOSANO, Mario G. Sistema e estrutura no Direito. Tradução de C.A. Dastoli. São Paulo: Martins Fontes, 2008, p.149: "Enquanto Kant reconhece à paz perpétua o valor de fim a que se deve tender, mesmo que irrealizável, Hegel a rejeita, decididamente, porque ela está fundada na vontade de cada Estado e, portanto, é acidental e imprevisível".

25 MELLO, Celso D. de Albuquerque. Curso de Direito Internacional Público. 15. ed. São Paulo: Renovar, 2004, p. 1479. v.2. 
desarmamento, o que não constitui sua proposta inicial. Aliás, o Direito Internacional do Desarmamento já foi ampla e detalhadamente mapeado por R. F. More, em sua tese de doutorado publicada sob o nome Direito Internacional do Desarmamento: O Estado, a ONU e a Paz, a qual será utilizada em passagens importantes deste trabalho.

Além disso, a questão nuclear permite identificar aspectos muito interessantes para as discussões que se propõem na presente pesquisa, já que a imensa capacidade destrutiva das armas atômicas evoca verdadeira consternação internacional, que, com base numa leitura racional do risco que elas representam, propulsionou a construção de um verdadeiro microssistema normativo e institucional específico composto por diversos tratados multilaterais, organismos internacionais, acordos bilaterais, resoluções dos principais órgãos da ONU, convenções etc., permitindo, assim, um campo mais vasto para a avaliação da dinâmica sobre a questão do desarmamento nuclear.

Do mesmo modo, as armas nucleares permitem considerar exemplos mais concretos da relação de tensão existente entre o Direito Internacional e as Relações Internacionais, considerando que, pelo relevante peso a elas atribuído na definição de políticas e estratégias nacionais de defesa, tratar de seu banimento representa abalar significativamente pilares sobre os quais se assenta a política internacional desde o fim da Segunda Guerra Mundial.

O imenso poderio militar dos detentores de tais armamentos, e a preponderância que possuem perante os demais Estados, permite que as potências nucleares adotem posturas ambíguas, contraditórias, às vezes, reconhecendo sua ameaça e apoiando retoricamente seu banimento, mas havendo grande hesitação para abandoná-las efetivamente. A questão da política do poder, neste particular, assume papel peculiar que rivaliza com os ideais, universalmente reconhecidos, que impõem objetivos como o da não proliferação de armas e do completo desarmamento:

Para qualquer potência, a principal consideração a fazer a respeito das propostas de desarmamento é o efeito que estas últimas terão sobre a relação de poder. Talvez seja verdade que as potências satisfeitas serão favoráveis a uma limitação das armas, uma vez que isto congelaria um equilíbrio de poder que as favorece. Dessa forma, a Grã-Bretanha manifestou-se favoravelmente a uma limitação das armas na Conferência de Haia de 1907, pois isso teria o efeito de confirmar sua preponderância naval e afastar a ameaça de competição por parte da Alemanha; e os 
Estados Unidos, por sua vez, apresentaram o plano Baruch, que teria confirmado sua supremacia atômica, além de afastar a ameaça representada pela competição russa nessa área. Dessa mesma maneira, as potências insatisfeitas resistem à limitação de armamentos, que dificultaria suas tentativas de alterarem o equilíbrio do poder em seu favor e consequentemente melhorar sua posição relativa. ${ }^{26}$

Há, do mesmo modo, a utilização política da questão nuclear, não necessariamente para se buscar uma afirmação internacional, ou um reconhecimento de poderio que acaba dissuadindo eventuais adversários a adotarem posturas mais radicais uns contra os outros, mas, diversamente, para que se postule uma ajuda internacional como barganha política, como verificado no comportamento norte-coreano que antecedeu seu rompimento mais radical com o regime de não proliferação nuclear:

Outra interpretação do mesmo comportamento é que ele permite uma estratégia de "compensação pela crise", tentando obter o máximo benefício material por meio da confrontação diplomática. Desse ponto de vista, os movimentos que antecederam o acordo - as ameaças de retirada do TNP, o desrespeito às obrigações de salvaguarda etc. - propiciaram um estrondoso sucesso: dois reatores de água leve por um preço de US\$ 5 bilhões e derivados de petróleo além da normalização com os EUA denotam um tratamento muito positivo que ultrapassa qualquer outro exemplo de tratamento diferenciado no campo do controle de armas ${ }^{27}$.

Dessas breves considerações já se vislumbra o rico contexto para se explorar a questão do desarmamento nuclear, partindo do ideal kantiano para sua conformação e desenvolvimento, cujo processo evolutivo é marcado por inúmeros percalços e limites de ordem política e pragmática, permitindo, assim, identificar a interação complexa entre o direito internacional e os obstáculos impostos pela política do poder nas relações internacionais.

Esse traço, aliás, reforça a identificação de tal construção com aquela descrita para a obtenção da paz perpétua.

26 WIGHT, Martin. A política do poder. Tradução de Carlos Sérgio Duarte. Brasília: Editora UnB, 1985, p. 169-170.

27 LODGAARD, Sverre. Proliferation: Relevant Factors. In: Curbing the Spread of Nuclear Weapons - an Informal Panel Discussion on the Occasion of the 20th Anniversary of the Vienna International Centre. Outubro 1999. Disponível em: <http://www.iaea.org/newscenter/focus/npt/curbing spread nuclear_weapons.pdf>. Acesso em: 20 jun. 2013, tradução livre do original em inglês. 
Assim, a pesquisa parte de Kant, pois, muito provavelmente, ele tenha sido o autor que, numa etapa importante do desenvolvimento do direito internacional, tratou do tema da pacificação internacional, muito próximo ao do desarmamento, de maneira mais aprofundada e corajosa, especialmente se relembrarmos o contexto político da época, em que a Europa constituía um cenário para inúmeros conflitos intermitentes ${ }^{28}$.

Entretanto, é importante ressalvar que a presente pesquisa não utilizará o projeto kantiano sob um prisma dogmático, nem tampouco terá a pretensão de desenvolver sua avaliação de como e em que medida o ensaio À Paz Perpétua pode ser atualmente verificado na prática, temas que escapam ao objeto da análise ora proposta ${ }^{29}$.

É indispensável ter em mente também que não se está aqui propondo um esgotamento completo do projeto de Kant sobre a paz perpétua como fundamento do desarmamento, mas, especificamente, a avaliação de que em que medida seria possível verificar nele a proposição de uma ideia reguladora cuja busca propicia a pavimentação de um caminho de evolução e construção internacional, "um novo caminho que os Estados poderão adotar um dia, mesmo que, passo a passo, num processo que demandará anos até que seja concluído" ${ }^{30}$. Nessa construção é que se tentará inserir o desarmamento internacional, ora analisado estritamente em relação às armas nucleares.

Nesse sentido, questões relevantes do projeto cosmopolita como a do republicanismo, do federalismo, ou mesmo da publicidade dos atos governamentais não terão uma análise exauriente, ainda que sejam eventualmente retomadas de modo pontual ao longo do trabalho.

O trabalho, então, terá sua primeira parte destinada à questão da avaliação da possibilidade de se relacionar o projeto kantiano À Paz Perpétua com o desarmamento nuclear, sob o prisma resumido nessa introdução, na tentativa de identificar como esse

28 É interessante notar que a proposição de Kant não era marcada por uma crença inquebrantável de que a humanidade caminhava para a paz. Ele não teria determinado a inevitabilidade da paz perpétua, mas apenas afirmado que essa condição não era impensável. Cf. WALTZ, Kenneth N. O homem, o estado e a guerra. Tradução de Adail Ubirajara Sobral. São Paulo: Martins Fontes, 2004, p. 204.

29 Ver HABERMAS, Jürgen. Kant's Idea of Perpetual Peace: At Two Hundred Years' Historical Remove. In: __. The Inclusion of the Other - Studies in Political Theory. Editado por C. Cronin. Massachussets: MIT Press, 1998.

30 CASSESE, Antonio. International Law in a Divided World. Oxford: Oxford University, 1986, p. 400407. 
projeto pode servir de paralelo balizador para a construção do desarmamento nuclear, com as ressalvas e limitações temáticas já antecipadas.

A seguir, a segunda parte do trabalho lançará as bases efetivas para a avaliação concreta do tema do desarmamento nuclear, contendo descrição analítica dos principais mecanismos institucionais, normativos e para-institucionais desenvolvidos em prol do desarmamento nuclear. Essa parte destina-se à análise das principais conquistas internacionais, como elas foram obtidas, eventuais ambiguidades e a utilização oportunista que delas se fez, bem como a maneira como elas se relacionam e se retroalimentam etc.

Devido à existência de múltiplos instrumentos desenvolvidos para o desarmamento nuclear, essa parte foi subdividida em cinco capítulos de modo a propiciar uma análise mais cuidadosa de cada um desses instrumentos e suas peculiaridades: (i) contextualização histórica de como surgiu e se desenvolveu a era nuclear para se compreenderem as principais características do tratamento internacional dado ao tema, (ii) o Tratado de Não Proliferação Nuclear, (iii) a Agência Internacional de Energia Atômica e a atuação do Conselho de Segurança da ONU, (iv) as zonas livres de armas nucleares e (v) demais iniciativas complementares como projetos de tratados, resoluções e, inclusive, medidas voluntárias não submetidas a um regime institucional ou normativo formalmente organizado.

A terceira parte da pesquisa destina-se à avaliação da relação entre os princípios do direito internacional aplicado aos conflitos armados, consagrados internacionalmente desde meados do século XIX, e as armas nucleares, analisando em que medida eventuais incompatibilidades permitem ou não afirmar a ilegalidade das armas nucleares.

Para tanto, além da análise desses princípios, desenvolvida no primeiro capítulo dessa terceira parte do trabalho, no segundo capítulo será analisado seu teste valorativo concreto, que foi realizado por ocasião da prolação da Opinião Consultiva da Corte Internacional de Justiça, em 1996, sobre a legalidade do uso ou da ameaça de uso das armas nucleares.

A partir dessa experiência da Corte Internacional de Justiça, e das ponderações críticas feitas a ela, especialmente de ordem política, como se verá no capítulo em questão, serão propiciadas as bases para a quarta e última parte da pesquisa, que contém uma análise do comportamento dos Estados em relação ao funcionamento do aparato que 
sustenta atualmente o desarmamento nuclear. Nessa parte, os aspectos políticos acirrados depois do fim da Guerra Fria constituirão o cerne das preocupações, como o terrorismo internacional, a ameaça de novos países proliferadores de armas nucleares e o alargamento do direito à autodefesa pelos ataques preventivos contra eles.

Todas essas questões políticas, como será observado, interagem de maneira umbilicalmente essencial para o funcionamento de todo o aparato institucional e normativo desenvolvido sobre o desarmamento nuclear, à medida que representam incentivos ou desestímulos ao apoio internacional e, portanto, à sua eficácia.

Espera-se, ao longo do caminho traçado em linhas gerais, compreender se é possível considerar o desarmamento nuclear como uma meta reguladora, cuja observância pode representar pequenas conquistas numa escala evolutiva e, do mesmo modo, acusar quais são os obstáculos para sua concretização. 
PARTE I

\section{PROJETO KANTIANO PARA A PAZ PERPÉTUA COMO BALIZA REFERENCIAL DO DESARMAMENTO NUCLEAR}




\section{1 À PAZ PERPÉTUA E O DESARMAMENTO NUCLEAR}

Muito já se escreveu sobre o papel das normas desenvolvidas para regulamentar a guerra como um elemento catalisador no desenvolvimento do Direito Internacional ${ }^{1}$.

Swinaerski, por exemplo, ao reconhecer que os primeiros contatos mesmo entre grupos sociais e comunidades que ainda não podiam ser classificadas como Estados modernos já se pautavam, sobretudo, em relações conflituosas, situa o direito consuetudinário da guerra na própria gênese do desenvolvimento do Direito Internacional Público. Não deixa de ser interessante sua conclusão no sentido de que:

as regras consuetudinárias do direito da guerra, tendo surgido quase no início das relações entre as comunidades, apresentam em todas as partes um conteúdo idêntico e finalidades análogas. Este surgir espontâneo nas diferentes civilizações - que não dispunham então de meios para comunicar-se entre si - é um acontecimento importante; é a prova de que a necessidade da existência de normas no caso de um conflito armado fazia-se sentir de igual maneira em civilizações muito diferentes. ${ }^{2}$

Seria limitada, contudo, a visão do Direito Internacional apenas como fruto do desenvolvimento de normas criadas para conter e regulamentar conflitos. Importante exemplo de que essa visão seria demasiadamente estreita encontra-se em Cícero, que, concebendo uma civitas maxima, já na antiguidade defendia que os ideais de convívio harmonioso e pacífico constituíam deveres justos.

1 ACCIOLY, Hildebrando; NASCIMENTO E SILVA, Geraldo E. do; CASELLA, Paulo Borba. Manual de Direito Internacional Público. 16. ed. São Paulo: Saraiva, 2008, p. 813: "as fontes das leis da guerra correspondem às do direito internacional em geral"; ALVES PEREIRA, Antonio Celso. O recurso à força pelos Estados e a legítima defesa no direito internacional contemporâneo. In: MENEZES DIREITO, Carlos Alberto; CANÇADO TRINDADE, Antonio Augusto; ALVES PEREIRA, Antonio Celso (Orgs.). Novas Perspectivas do Direito Internacional Contemporâneo - Estudos em homenagem ao Professor Celso D. de Albuquerque Mello. São Paulo: Renovar, 2008, p. 3: "O Direito Internacional clássico nasceu influenciado pela consolidação do processo de secularização do Estado, como um direito da guerra."; HENCKAERTS, Jean-Marie; DOSWALD-BECK, Louise. Customary International Humanitarian Law. New York: Cambridge University Press / International Committee of The Red Cross, 2005, p. XXXI: "International humanitarian law has its origins in the customary practices of armies as they developed over the ages and on all continents."

2 SWINAERSKI, Cristophe. O direito internacional humanitário como sistema de proteção internacional da pessoa humana. In: VIEIRA, Oscar Vilhena (Coord.). Direitos Humanos - Estado de direito e a construção da paz. São Paulo: Quartier Latin, 2005, p. 161. 
É interessante notar, por exemplo, a maneira pela qual o filósofo romano concebia como dever, a ser zelado pela justiça, a conduta de ajuda mútua entre os homens, indistintamente ${ }^{3}$.

Observa-se que as questões atinentes tanto ao direito à guerra quanto ao direito da guerra, apesar de muito relevantes, não constituem o único elemento que estimulou o desenvolvimento do Direito Internacional. Ao mesmo tempo em que guerreavam nos primórdios, e continuam guerreando ainda hoje, povos, nações e Estados relacionavam-se e seguem se relacionando também por inúmeras outras razões, ideológicas, comerciais, econômicas, culturais etc.

Feita a ressalva, ainda assim permanece válida a percepção de que a disputa e o conflito com outros povos foi e segue sendo uma marca constante da História e do desenvolvimento do Direito Internacional.

Essa relação conflituosa advinha, inicialmente, da simples competição por vantagens que repercutiriam em favor de cada povo, fossem elas naturais - como o acesso a fontes de água ou a solos férteis, num primeiro momento -, fossem representadas por bens e artifícios criados pelo homem, tais como plantações, reservas, açudes e fortificações.

A inerente disputa por poder e segurança entre os povos, que se conecta a essa interação competitiva, permite compreender por que é tão recorrente a questão da guerra no Direito Internacional, tendo se verificado detalhadamente desde seu período clássico, conforme o destaque que Marotta Rangel efetuou ao prefaciar a edição brasileira da obra de Vattel: "Refere-se o terceiro livro a questões integrantes do jus belli que até Vattel, e mesmo depois dele, ocupavam a maior parte da temática do direito das gentes". 4

Esse dado da realidade potencialmente conflituosa entre os Estados assumiu maior relevância à medida que se ampliava o potencial destrutivo dos meios de se fazer a guerra.

3 CÍCERO. Dos deveres. Tradução de A. Marins. São Paulo: Martin Claret, 2002, p. 37: “O primeiro dever imposto à justiça é não fazer mal a ninguém, a menos que se tenha de rebater um insulto; o segundo é empregar em comum os bens de comunhão e tratar como próprios apenas os que nos pertencem. [...] Segundo os estoicos, todos os produtos da terra se reservam aos usos dos homens, e os próprios homens são criados por seus semelhantes, a fim de que possam se ajudar uns aos outros; devemos, por isso, adotar por guia a natureza, colocando nossas faculdades a serviço de um comércio mútuo de boa vontade, empenhados tanto em dar como em receber, aplicando nossos talentos, nossa indústria, em garantir os laços sociais".

4 RANGEL, Vicente Marotta. Prefácio à edição brasileira. In: VATTEL, Emmer de. O Direito das Gentes. Brasília: Universidade de Brasília, 2004, p. LXII-LXIII. 
Os esforços internacionais nesse sentido, inicialmente de modo incipiente a partir da segunda metade do século XIX, e, com mais ênfase, ao longo do século XX, representam o que se afirma aqui, conforme será abordado no capítulo 1, da terceira parte deste trabalho.

Assim como houve o aprimoramento de normas que fundaram as bases sociais necessárias para se transcender o estado de natureza em que viviam os homens, então constantemente ameaçados uns pelos outros ${ }^{5}$, em âmbito internacional verificou-se a mesma necessidade entre os Estados.

É interessante a descrição de Bobbio sobre a linearidade que deve haver nesse processo evolutivo da superação do estado de natureza, ultrapassando o nível doméstico até se espraiar para a esfera internacional:

A constituição do estado civil resolve o problema das relações entre os indivíduos no estado de natureza. Esse evento constituiu o triunfo do direito sobre o estado não-jurídico, ou somente provisoriamente jurídico. Mas, com a constituição do Estado, ou seja, com a supressão do estado natural entre os indivíduos, o triunfo do direito não é ainda completo. Aquele mesmo estado de natureza que estava em vigor antes da constituição do Estado entre os indivíduos, continua vigendo nas relações entre os Estados. O triunfo do direito na sociedade humana não será completo enquanto não for instaurado um estado jurídico civil e nãonatural também entre os Estados ${ }^{6}$.

Especialmente depois dos devastadores conflitos mundiais deflagrados durante o século XX, a necessidade do desenvolvimento de um estado jurídico civil entre os Estados tornou-se mais premente.

Como resultante desse contexto, pode-se mencionar a crescente diversificação e aprimoramento de normas internacionais que limitam o modo pelo qual os Estados podem fazer a guerra. Ainda mais importante, verificou-se também a sedimentação da paz como um ideal a ser defendido e buscado pelos Estados e demais atores da sociedade internacional.

5 É interessante notar a observação de Rousseau sobre o aspecto de que, no estado de natureza, não haveria uma propensão inata ao homem para guerrear contra seus semelhantes: ROUSSEAU, Jean-Jacques. O Estado de Guerra nascido no Estado Social. In: . Rousseau e as relações internacionais. Tradução de Sérgio Bath. São Paulo: Imprensa Oficial do Estado, 2003, p. 49-53.

6 BOBBIO, Norberto. Direito e Estado no pensamento de Emanuel Kant. Tradução de Alfredo Fait. 3. ed. Brasília: UnB, 1995, p. 153. 
Não se trata meramente de um posicionamento ideológico, mas de uma constatação de um dos reflexos decorrentes do instinto básico de sobrevivência em relação à destruição potencialmente ampliada da guerra.

Hannah Arendt, discorrendo sobre o posicionamento kantiano acerca do mecanismo de evolução histórica da razão humana, chega a afirmar que "a guerra traz o progresso [...]. E a guerra traz mesmo o progresso rumo à paz: a guerra é tão terrível que, quanto mais terrível ela se torna, mais é provável que os homens venham a ser razoáveis e trabalhem tendo em vista acordos internacionais que os conduzam eventualmente à paz" 7 .

Identificando concretamente o que fora antevisto na proposição kantiana, e bem retomado na leitura de Arendt, Habermas descreve sucintamente os avanços gerados pela terrível experiência da guerra total que marcou o século XX:

Atrás do véu da Guerra total instigada por Hitler, o colapso da civilização foi tão completo que disseminou um movimento de ruptura mundial e facilitou a transição do direito internacional para o direito cosmopolita. Primeiramente, a proscrição da guerra, já proclamada pelo Pacto BriandKellog de 1928, foi traduzida em ofensas criminais passíveis de punição pelos tribunais militares de Nuremberg e Tóquio. Tais ofensas não são mais limitadas a crimes cometidos durante a guerra, mas incriminam a própria guerra como um crime. [...] Em segundo lugar, o direito criminal foi ampliado para incluir 'crimes contra a humanidade', crimes cometidos em cumprimento de instruções de órgãos oficiais estatais e com apoio de extensos membros e escalões da administração pública. Com essas duas inovações, os Estados como sujeitos do Direito Internacional pela primeira vez abandonam a presunção geral de inocência de um suposto estado de natureza. ${ }^{8}$

7 ARENDT, Hannah. Lições sobre a filosofia política de Kant. Tradução de André Duarte de Macedo. Rio de Janeiro: Relume-Dumará, 1993, p. 71.

8 HABERMAS, Jürgen. Kant's Idea of Perpetual Peace: At Two Hundred Years' Historical Remove. In: . The Inclusion of the Other - Studies in Political Theory. Cambridge: MIT Press, 1998, p. 178, tradução adaptada nossa do original seguinte: "Behind the veil of the total war instigated by Hitler, the breakdown of civilization was so complete that it unleashed a worldwide upheaval and facilitated the transition from international law to cosmopolitan law. First, the outlawing of war already proclaimed by the Briand-Kellogg Pact of 1928 was translated into punishable criminal offenses by the Nuremberg and Tokyo military tribunals. These offenses are no longer limited to crimes committed during war, but incriminate war itself as a crime. [...] Second, criminal law was extended to include 'crimes against humanity', crimes carried out under the instructions of state organs and with the assistance of countless members of organizations, functionaries, civil servants, businessmen, and private individuals. With these two innovations, the states as subjects of international law for the first time lost the general presumption of innocence of an assumed state of nature". Ver ainda TRUYOL Y SERRA, Antonio. La sociedad internacional. Madri: Alianza Editorial, 1994, p. 83. 
Muitas conquistas foram obtidas nesse processo, em especial mediante o estabelecimento do sistema onusiano, que, para muitos autores, representa um conjunto de valores que constituem verdadeira subversão dos pilares do período clássico do Direito Internacional.

É bastante eloquente, neste particular, a constatação deque, a partir do término da Segunda Guerra Mundial, o direito de recorrer à guerra deixou de ser uma prerrogativa reservada aos Estados, deslocando-se exclusivamente à esfera de atuação da ONU ${ }^{9}$.

Cassese, reforçando a percepção dessas mudanças intensas, reconhece a construção de um novo sistema jurídico internacional muito mais evoluído do que o prevalecente até então, que era maculado por intenso realismo, mero reflexo do arranjo de poderes de acordo com o domínio das principais nações, que moldavam o arranjo instrumental jurídico do modo que lhes fosse mais conveniente ${ }^{10}$.

Segundo o autor, apesar da dificuldade de o novo sistema se sobrepor aos dogmas cristalizados até principalmente a Segunda Grande Guerra, essa guinada fez-se sentir pela crescente influência que o Direito Internacional passa a exercer com mais eficácia sobre o direito doméstico, pela consolidação das normas que determinam restrições severas ao uso da força, pelo reconhecimento de que atores não estatais também deveriam ser considerados como sujeitos de direito no plano internacional, pela crescente defesa internacional dos direitos humanos etc.

Mesmo que existam críticas pertinentes contra falhas e imperfeições dessa nova realidade, não se pode ignorar o enorme avanço representado pelas previsões da Carta de São Francisco na estruturação de uma realidade cada vez mais pacífica.

Ainda segundo Cassese, nesse sentido, o Direito Internacional tende a abandonar seu viés mais realista, que até então apenas refletia em normas as relações de poder existentes como meio de assegurar sua eficácia, tornando-se cada vez mais idealista ${ }^{11}$.

9 MELlo, Celso D. de Albuquerque. Curso de Direito Internacional Público. 15. ed. São Paulo: Renovar, 2004, p. 1504. v. 2. Caberia uma menção, como referência histórica, ao Tratado Brian-Kellogg, de 1928, que declarou a renúncia à guerra, porque não havia uma necessária formalização sobre qual seria o detentor do monopólio da força para apresentar reação em caso de perturbação e conflitos internacionais.

10 CASSESE, Antonio. International Law in a Divided World. Oxford: Oxford University, 1986, p. 400.

11 Ibidem. 
Fonseca Jr. aborda essa questão com franqueza, assumindo a existência de imperfeições no sistema onusiano, mas reafirmando que não são suficientes para apagar os avanços com ele obtidos $^{12}$ :

\begin{abstract}
Afinal, tanto a Liga quanto a ONU foram criadas, depois de guerras terríveis, para que, com mecanismos e instrumentos sólidos, as soluções pacíficas prevalecessem. Infelizmente, as instituições, ainda que tivessem sucesso relativo, não foram sempre capazes de cumprir seus ideais. Mas deram passos para aperfeiçoar o relacionamento entre os Estados.
\end{abstract}

Acompanhando essas conquistas, um outro foco que passou a ganhar cada vez mais atenção para a construção da paz nessa nova etapa do Direito Internacional foi o desarmamento.

Com efeito, dada a relevância que a questão da guerra possui para as relações entre os Estados, um meio eficaz de contê-la é justamente o controle, ou mesmo o banimento, como meta maior, das armas, o principal instrumento historicamente utilizado pelos Estados para a "imposição de sua segurança institucional" 13 .

É oportuna a lembrança trazida por Wight ${ }^{14}$, neste particular, da fala de Bismarck: “as grandes questões de nossa época não serão solucionadas por resoluções e votos majoritários - este foi o erro dos homens de 1848 e 1849 - mas a sangue e ferro".

Neste sentido, ao se propor a limitar, conter ou proscrever os instrumentos da guerra, o desarmamento seria o reflexo da busca pela paz internacional como um ideal balizador, um valor superior a ser buscado. Observa-se, aí, o papel estruturante do valor da paz, propiciando a edificação cada vez mais sólida de uma realidade pacífica por meio do desenvolvimento e fortalecimento do desarmamento internacional ${ }^{15}$.

12 FONSECA Jr., Gelson. As múltiplas dimensões do pensamento de Rousseau. (Primeira parte do Prefácio). In: ROUSSEAU, Jean-Jacques. Rousseau e as relações internacionais. São Paulo: Imprensa Oficial do Estado, 2003, p. XXXV.

13 MORE, Rodrigo Fernandes. O desarmamento no sistema de segurança coletiva da ONU. 2005. Tese (Doutorado) - Faculdade de Direito, Universidade de São Paulo, São Paulo, 2002, p. 16: "Naturalmente, não há como dissociar as armas da guerra, ou mais modernamente dos conflitos armados".

14 WIGHT, Martin. A política do poder. Tradução de C. S. Duarte. Brasília: Editora UnB, 1985, p. 18.

15 Interessante e pertinente descrição das distintas facetas da "paz", incluindo-se seu papel estruturante, encontra-se na dissertação de mestrado do já citado Rodrigo Fernandes More, intitulada Fundamentos das operações de paz das Nações Unidas e a questão de Timor Leste. Faculdade de Direito, Universidade de São Paulo, São Paulo, 2002. 
Lafer $^{16}$ resume bem esse papel do desarmamento ao descrevê-lo como "pacificismo instrumental, que busca reduzir os riscos de guerra eliminando ou controlando os seus meios, que são os armamentos".

Ocorre que o desarmamento internacional, exatamente por atacar o principal meio utilizado pelos Estados para "imporem sua segurança institucional", acaba se tornando profundamente polêmico e, por isso mesmo, duramente questionado, uma vez que "desafia muitos dos fundamentos legais e políticos da segurança interna dos Estados e do principal elemento de dissuasão nas Relações Internacionais" ${ }^{17}$.

Por esse motivo é que muitos críticos do desarmamento enxergam apenas as limitações e obstáculos impostos pela política de poder que marca a conduta dos Estados, avessos a abdicarem de posições vantajosas atribuídas pelas armas no tabuleiro das relações internacionais.

Em certa medida, a crítica é pertinente porque, a rigor, são vagarosos os avanços na temática do desarmamento internacional e, ainda assim, suas conquistas muitas vezes são explicadas apenas por atenderem a interesses inconfessados dos Estados, não pelo reconhecimento dos valores maiores a serem buscados.

Wight $^{18}$ resume bem essa instrumentalização do discurso politicamente correto do desarmamento para escamotear interesses políticos individuais, quando menciona que

16 LAFER, Celso. Comércio, desarmamento e direitos humanos - reflexões sobre uma experiência diplomática. 2. ed. São Paulo: Paz e Terra, 2006, p. 117. Ainda do mesmo autor, ver Paradoxos e possibilidades. Rio de Janeiro: Nova Fronteira, 1982, p. 86.

17 MORE, Rodrigo Fernandes. O desarmamento no sistema de segurança coletiva da ONU. 2005. Tese (Doutorado) - Faculdade de Direito, Universidade de São Paulo, São Paulo, 2002, p. 16. Interessante a ressalva que Hedley Bull (A sociedade anárquica. Tradução de Sérgio Bath. São Paulo: Universidade de Brasília, 2002, p. 266) faz sobre a circunstância de o potencial bélico não se limitar apenas aos armamentos de uma nação, mas também residir em todo o complexo dos recursos econômicos, tecnológicos e demográficos, sua posição estratégica, liderança política, engenho e experiência militares, moral nacional etc. Nesse sentido, vale adicionar o reconhecimento de John Foster Dulles sobre a relevância do poderio industrial norte-americano ter atuado tanto como força de dissuasão contra a guerra total, quanto como meio de vencê-la. Cf. GADDIS, John Lewis. The Unexpected John Foster Dulles: Nuclear Weapons, Communism and the Russians. In: IMMERMAN, Richard H. John Foster Dulles and the Diplomacy of the Cold War. New Jersey: Princeton University, 1990, p. 55, conforme o original em inglês: "In the end, Dulles concluded, the only real solution for the problem of expanding Soviet nuclear capabilities might be nuclear abolition. [...] it could be argued that atomic weapons are the only ones by which the U.S. can be virtually destroyed through a sudden attack, and if this danger of destruction should be removed by eliminating nuclear weapons this would help the U. S. by enabling retention intact of our industrial power which has acted both as deterrent against total war and as a principal means of winning a war".

18 WIGHT, M. A política do poder. Tradução de C. S. Duarte. Brasília: Editora Universidade de Brasília, 1985, p. 169-170. Vale notar o exemplo dado pela postura da Grã-Bretanha na Conferência de Haia de 
"para qualquer potência, a principal consideração a fazer a respeito das propostas de desarmamento é o efeito que estas últimas terão sobre a relação de poder”. Desse modo, o apoio para as questões do desarmamento é intensificado por Estados que as identifiquem como meio de congelar o "equilíbrio de poder que as favorece".

Essas dificuldades permitem, de fato, verificar um viés bastante idealista no desarmamento. Segundo More, "o desarmamento geral e completo é um objetivo de inspiração kantiana do sistema de Estados, perseguido por meio de tratados parciais que cuidam, cada um de forma especial, de uma categoria ou de classe de armas distintas"19.

Entretanto, especialmente a partir dos últimos atos da Segunda Guerra Mundial, quando o mundo deparou-se pela primeira vez com sua possível destruição completa, a problemática do desarmamento internacional assumiu um papel destacado na agenda da preocupação dos Estados em busca de uma realidade aceitável:

O uso da bomba atômica iniciou uma nova era: o uso da energia atômica e nuclear para propósitos bélicos significando que os Estados eram capazes de aniquilarem o planeta inteiro ou grandes porções dele. A questão de como estabelecer restrições aos meios de destruição, que foi tratada pela comunidade internacional desde meados do século XIX, tornava-se uma questão central. ${ }^{20}$

Se em sua concepção genérica o desarmamento internacional já poderia ser considerado um elemento de inspiração kantiana, idealista por natureza, no que concerne ao desarmamento nuclear especificamente considerado, essa aproximação com os ideais do filósofo alemão é ainda mais evidente.

1907, que se manifestou favoravelmente a uma limitação das armas, pois confirmaria sua preponderância naval contra as ameaças de competição por parte da Alemanha.

19 MORE, Rodrigo Fernandes. O desarmamento no sistema de segurança coletiva da ONU. 2005. Tese (Doutorado) - Faculdade de Direito, Universidade de São Paulo, São Paulo, 2002, p. 19.

20 CASSESE, Antonio. International Law in a Divided World. Oxford: Oxford University, 1986, p. 64. Tradução livre do original: "The dropping of the atomic bomb began a new era: the use of atomic and nuclear energy for warlike purposes meant that States were now capable of annihilating the entire planet or huge portions of it. The question of how to place restraints on the use of means of destruction, which had exercised the international community since at least the middle of the nineteenth century, now became the central issue". 
Seu inaceitável potencial destrutivo ${ }^{21}$, incomparável ao de qualquer outra arma convencional, necessariamente situa tais armas em polo diametralmente oposto àquele que se espera como sendo o resultante de uma evolução histórica da humanidade pautada pela razão.

Novamente é útil mencionar a leitura de Arendt sobre os escritos políticos de Kant, quando se refere a um “'grande propósito da natureza' trabalhando por trás dos homens que agem. De outro modo, a raça de demônios destruir-se-ia a si mesma (em Kant, o mal geralmente é autodestrutivo). A Natureza quer a preservação da espécie, e tudo o que ela exige de seus filhos é que se auto preservem e usem a cabeça" ${ }^{22}$.

Trazendo essa referência para a questão das armas nucleares, o salto tecnológico demonstrado pela conquista da energia atômica em sua faceta mais perigosa deveria, necessariamente, ser acompanhado também por um salto qualitativo no estabelecimento de normas que impedissem os Estados de desenvolverem políticas de defesa nacionais vislumbrando a posse e o uso de tais armas, conforme bem resumido por Einstein ${ }^{23}$ :

\begin{abstract}
A potência desencadeada do átomo mudou tudo, salvo nossos modos de pensar, e deslizamos assim para uma catástrofe sem precedente. Uma nova maneira de pensar é essencial se a humanidade deve sobreviver. Desviar essa ameaça tornou-se o mais urgente problema de nossa época.
\end{abstract}

Nesse exato sentido, muito valiosa a síntese de Shinso Hamai, funcionário da administração pública de Hiroshima à época do ataque nuclear contra Hiroshima, e prefeito da cidade em mandatos sucessivos entre 1947 e 1967, em discurso proferido por ocasião da cerimônia de celebração do segundo aniversário do lançamento da bomba: "Essa arma

21 ZUCKERMAN, Solly. Nuclear Illusion and Reality. New York: The Viking, 1982, p. 15, tradução livre: "A diferença vital entre as armas convencionais e as nucleares é a de que enquanto para quaisquer propósitos existe um limite da quantidade de destruição que pode ser causada pela explosão de uma bomba convencional, não há limites para a destruição causada por uma ogiva nuclear".

22 ARENDT, Hannah. Lições sobre a filosofia política de Kant. Tradução de André Duarte de Macedo. Rio de Janeiro: Relume-Dumará, 1993, p. 27.

23 ANGELOPOULOS, Angelos. O átomo unirá o mundo. Tradução de Raul Lima. Rio de Janeiro: Edições Financeiras, 1956, p. 73, apud ABRANCHES, C. A. Dunshee de. Proscrição das armas nucleares. São Paulo: Freitas Bastos, 1964, p. 100-101. 
terrível trouxe uma 'revolução do pensamento', que nos convenceu da necessidade e do valor da paz eterna." 24

Assim, com respeito às armas de destruição em massa, notadamente as armas nucleares, tanto é possível respeitar essa revolução do pensamento para vislumbrar um futuro desejável, e lutar por sua obtenção, quanto lidar com as bases do mundo real e aceitar a sina que este propiciar em alguns anos ou décadas ${ }^{25}$.

Não parece haver dúvida sobre qual o rumo a se trilhar caso o problema seja situado entre se optar por um tratamento desse tema de acordo com uma concepção jurídica ou meramente político-descritiva desse tema tão relevante para o direito internacional e para as relações internacionais. Como ensina Casella ${ }^{26}$,

enquanto o direito internacional tem de preservar determinados fins e determinados princípios, mesmo quando falhe em lhes assegurar a efetividade e a aplicação corrente, as relações internacionais, tautologicamente, são essencialmente relacionais: se fundam e se desenvolvem mediante consenso, mediante composição de interesses, guiadas pela prudência, enquanto ensinamento prático, decorrente do senso comum, da experiência e das lições da história: não contêm nem trazem valores intrínsecos, ou conteúdos precisos [...] não são idealistas, são pragmáticas.

Essas lições assemelham-se à resposta de Rousseau à indagação lançada por ele próprio, relativa à importância de se considerarem à luz da Justiça os erros humanos ou a sua barbárie:

Ora, devemos procurar não o que tem sido feito, mas o que deve ser feito, ignorando as autoridades malignas e mercenárias que terminam escravizando os homens, tornando-os maus e terríveis. ${ }^{27}$

24 HAMAI, Shinso. A-Bomb Mayor - Warnings and Hope from Hiroshima. Tradução de Elizabeth W. Baldwin. Hiroshima: Toppan, 2010, p. 97, tradução do original: "This horrible weapon brought about a 'Revolution of Thought', which has convinced us of the necessity and the value of eternal Peace".

25 THAKUR, Ramesh. Working for a Safer World. In: War in Our Time - Reflections on Iraq, Terrorism and Weapons of Mass Destruction. Tokyo: United Nations University, 2007, p. 32.

26 CASELLA, Paulo Borba. Fundamentos do direito internacional pós-moderno. São Paulo: Quartier Latin, 2008, p. 933-934.

${ }^{27}$ ROUSSEAU, Jean-Jacques. Fragmentos sobre a guerra. In: Rousseau e as relações internacionais. Tradução de Sérgio Bath. São Paulo: Imprensa Oficial do Estado, 2003, p. 66. 
Desse modo, pelo comportamento alinhado a valores superiores, o que deve ser feito, é que se estarão lançando as bases de uma construção, não uma mera repetição das mazelas e imperfeições do presente que ainda impedem falar-se na possibilidade concreta de um desarmamento nuclear completo e uma paz perene.

Não se ignora que há toda uma série de obstáculos a serem vencidos na construção dessa realidade idealizada.

Mas, segundo o próprio Kant, "se há ao mesmo tempo uma esperança fundada de tornar efetivo o estado de um direito público, então a paz perpétua, que sucede os até aqui falsamente assim denominados tratados de paz não é uma ideia vazia, mas uma tarefa que, solucionada pouco a pouco, aproxima-se continuamente de seu fim" 28 .

Sergio Vieira de Mello, revisitando especificamente o ensaio À Paz Perpétua, destacou essa dinâmica, ainda que possivelmente lenta e imperfeita, de construção do direito internacional rumo a uma conformação das bases que propiciarão uma paz universal e duradoura:

Com a irracionalidade como pano de fundo, a escolha, a codificação de certas normas fundamentais e a adesão a estas constituem a inauguração de um caminhar bastante longo e complexo que pode conduzir à construção de uma paz universal e duradoura. ${ }^{29}$

Para essa codificação, haveria, então, uma convergência dos Estados, que, observando as barbáries e os excessos surgidos em meio a uma realidade permeada por unilateralismos e discursos de desconfiança e de segurança nacional, optariam por trilhar o caminho, mesmo longo e difícil, rumo a uma paz universal e duradoura.

Trata-se de passos na direção de um possível ideal proposto no projeto kantiano da paz perpétua, com a humanidade extraindo da realidade lições propiciando uma evolução histórica pautada pela racionalidade.

28 KANT, I. À paz perpétua. Tradução de M. A. Zingano. São Paulo: L\&PM Editores, 1989, p. 80.

29 MELLO, S. V. de. História filosófica e História real: atualidade do pensamento político de Kant. In: MARCOVITCH, J. (Org.). Sérgio Vieira de Mello - pensamento e obra. São Paulo: Edusp / Saraiva, 2004, p. 38. 
Ainda segundo Vieira de Mello, haveria uma extração das "lições da brutalidade que caracteriza as relações interestatais para salientar que a razão poderia ter evitado uma tão longa e triste experiência aos povos e Estados, indicando-lhes a única saída concebível" 30 .

Extraindo das armas nucleares sua natureza brutal, indicando a única saída concebível, Abranches, em valioso estudo sobre a proscrição das armas nucleares desenvolvido ainda em 1964, já propunha que o cotejo analítico entre as nefastas consequências das armas nucleares viria a produzir, paradoxalmente, um efeito benéfico.

Segundo o autor, as nefastas consequências do uso das armas atômicas teriam criado dilema que apenas se resolveria pela solução de sobrevivência, determinando a relativização da ideia da soberania absoluta rumo a uma idealizada internacionalização do poder militar. Na sequência, atribui às armas nucleares papel de aceleradoras da modificação progressiva do conceito da soberania irrestrita, considerado falso pelo autor ${ }^{31}$. Essas percepções assemelham-se ao modo como Kant, no ensaio À Paz Perpétua, aborda a guerra como elemento que motiva evolução para um patamar superior das relações internacionais, podendo, então, ser verificada a possibilidade de servir como um balizador referencial para a construção e o desenvolvimento do desarmamento nuclear, já que, como se pode observar, segundo a análise de Abranches, seria necessário buscar a internacionalização do poder militar para atingir aquele objetivo. A internacionalização, nesse sentido, converge para a consolidação de bases de uma realidade cosmopolita, estágio final distante do desenvolvimento rumo à paz perpétua.

Faz-se necessário, assim como também foi afirmado por Kant, o reconhecimento de que para a consecução tanto de uma paz perene, quanto do completo desarmamento nuclear, inúmeros paradigmas devem ser superados, o que deverá ocorrer por meio de conquistas e avanços gradativos.

30 MELLO, Sérgio Vieira de. História filosófica e História real: atualidade do pensamento político de Kant. In: MARCOVITCH, J. (Org.). Sérgio Vieira de Mello - pensamento e obra. São Paulo: Edusp/Saraiva, 2004, p. 45

31 ABRANCHES, C. A. Dunshee de. Proscrição das armas nucleares. São Paulo: Freitas Bastos, 1964, p. 172-174. O questionamento do conceito de soberania consolidado no período clássico é tema recorrente, valendo mencionar novamente Celso Lafer (Comércio, desarmamento e direitos humanos - reflexões sobre uma experiência diplomática. 2. ed. São Paulo: Paz e Terra, 2006, p. 26-27.): “A característica do " "novo" Direito Internacional Público, que começa a surgir a partir do século XIX, como lembra Wolfgang Friedmann, é, em contraste, o gradual aparecimento de normas de mútua colaboração. Estas provêm das exigências de cooperação entre os Estados, as quais, por seu turno, constituem uma consequência da distância que começa a aflorar entre o pressuposto da plenitude irrestrita da " "soberania jurídica" e as possibilidades mais circunscritas da " "soberania operacional"”. 
A título de ilustração, vale destacar o famoso discurso de Eisenhower proferido em 1953, por ocasião da 470 Reunião Plenária da Assembleia Geral da ONU, quando lançou a iniciativa "Atoms for Peace", cuja proposta era buscar uma forma eficaz de evitar a proliferação nuclear, problema que deveria ser enfrentado pelo desarmamento dos países que detinham armas nucleares e a criação de um órgão supranacional de controle do material nuclear dos arsenais ${ }^{32}$.

A proposta, como é sabido, não se concretizou em sua plenitude, mas foi extremamente bem sucedida ao lograr o efeito positivo de fomentar as bases de discussão que culminaram na criação da Agência Internacional de Energia Atômica ${ }^{33}$, um dos principais organismos que atuam em prol do desarmamento nuclear, como será melhor descrito no capítulo 1 , da segunda parte deste trabalho.

Esse exemplo demonstra que, apesar de os diversos esforços no sentido do desarmamento nuclear terem "esbarrado na falta de vontade política de assegurar o cumprimento de tratados ou na recusa de permitir inspeção internacional eficaz" ${ }^{34}$, ainda assim as iniciativas em sua obtenção acabam determinando um avanço concreto de normas e instituições que o aproximam da realidade.

Por essa razão é que o ceticismo em relação ao desarmamento nuclear não pode prevalecer, sob pena de se jogarem por terra quaisquer possibilidades, mesmo mínimas, de suplantar uma realidade que já deu mostrar mais do que suficientes de que não atende a ideais mais elevados pautados pela racionalidade. Oportuna, novamente, a lição de Abranches:

não se justifica o pessimismo de alguns internacionalistas. O papel destes é preparar terreno, apontar rumos, ampliar os institutos vigentes e, se necessário, criar novos, de modo que, quando o estado das relações internacionais o permita, os instrumentos da proscrição estejam ao

32 SAMPAIO, Maria Feliciana Nunes Ortigão de. O Tratado de Proibição Completa dos Testes Nucleares $(C T B T)$ : Perspectivas para sua entrada em vigor e para a atuação diplomática brasileira. Brasília: Alexandre de Gusmão, 2012, p. 37.

33 IAEA (International Atomic Energy Agency). About us. Atoms for Peace. Disponível em: https://www.iaea.org/about. Acesso em: 13 dez. 2014.

34 ACCIOLY, Hildebrando; NASCIMENTO E SILVA, Geraldo E. do; CASELLA, Paulo Borba. Manual de Direito Internacional Público. 16. ed. São Paulo: Saraiva, 2008, p. 852. 
alcance dos estadistas, diplomatas e administradores, para a oportuna utilização. ${ }^{35}$

Vê-se, portanto, a similitude entre o ideal da paz perpétua e o desarmamento nuclear, porque, ainda que aquele seja considerado utópico pelos dados presentes da realidade, isso não impede que seja tomado como ideal a ser buscado, "tarefa que, solucionada pouco a pouco, aproxima-se continuamente de seu fim"36.

Além disso, é útil se valer do projeto kantiano para analisar o desarmamento nuclear porque há proposições práticas do filósofo alemão que se aplicam de modo bastante interessante em relação ao tema.

Nos comentários que formulou sobre os artigos preliminares do ensaio $\grave{A} P a z$ Perpétua, Soraya Nour destaca, na crítica aos exércitos permanentes, os elevados custos de sua manutenção, assim como o efeito desagregador que possuem, já que apenas sua existência, mesmo em tempos de paz, incita a insegurança e a desconfiança recíproca. A autora situa ainda essa crítica aos exércitos permanentes como a raiz da corrida armamentista experimentada no mundo contemporâneo ${ }^{37}$ :

O terceiro artigo preliminar critica a manutenção de exércitos permanentes. [...] O exército permanente de Friedrich II dispunha de 230 mil homens, em uma população de seis milhões de habitantes. Nos tempos de paz, 70 a $80 \%$ dos rendimentos do Estado eram destinados à manutenção do exército; nos tempos de guerra, no mínimo $90 \%$, onerando a população camponesa com altos impostos. [...] $\mathrm{O}$ argumento inicial de Kant é considerado a primeira descrição estrutural moderna da dinâmica própria da espiral armamentista: o Estado que se arma excessivamente para a guerra incita os outros Estados a quererem se armar mais ainda, num processo infinito.

Nesse pequeno trecho verificam-se temas recorrentemente analisados em relação ao desarmamento nuclear: elevadíssimos custos de desenvolvimento e manutenção de

35 ABRANCHES, C. A. Dunshee de. Proscrição das armas nucleares. São Paulo: Freitas Bastos, 1964, p. 169-170.

36 KANT, I. À paz perpétua. Tradução de M. A. Zingano. São Paulo: L\&PM Editores, 1989, p. 80.

37 NOUR, Soraya. À paz perpétua de Kant - filosofia do direito internacional e das relações internacionais. São Paulo: Martins Fontes, 2013, p. 31-32. 
$\operatorname{arsenais}^{38}$, desconfiança e desagregação gerada pela aquisição e manutenção de tais $\operatorname{armas}^{39}$, corrida armamentista ${ }^{40}$, por exemplo.

Observa-se a rica possibilidade de se se valer do projeto lançado por Kant. Além de fornecer uma ideia reguladora geral para a construção do desarmamento nuclear, permite que dele se extraiam lições conexas ao que já se verifica nas iniciativas em prol desse desarmamento, ou lições potenciais.

É o que será abordado nos tópicos seguintes, num primeiro momento analisando a validade de se utilizar a proposta kantiana para tal finalidade, para, na sequência, avaliar experiências concretas da construção do desarmamento nuclear sob seu prisma.

Antes de se enfrentar a questão da validade da utilização do projeto kantiano $\grave{A} P a z$ Perpétua como referência para a construção do desarmamento nuclear, são necessárias breves considerações sobre questões atuais que marcam essa problemática, no direito e nas relações internacionais.

A ponderação acerca do estágio atual do aparato internacional relacionado ao desarmamento nuclear é necessária para avaliar se aquele é compatível com valores sobre os quais deve ser erigida uma sociedade pacífica e harmoniosa. Caso negativa a resposta, aí sim terá pertinência analisarmos possíveis ganhos que adviriam do uso do projeto kantiano como referência maior para sua construção efetiva.

38 BANDEIRA, Luiz Alberto Moniz. A segunda guerra fria. Rio de Janeiro: Civilização Brasileira, 2013, p. 163: "Um estudo realizado no Brooking Institute, de Washington, estimou que os custos em armamentos nucleares, desde a Segunda Guerra Mundial até 2007, foram da ordem de US\$ 7,2 trilhões".

39 ZUCKERMAN, Solly. Nuclear Illusion and Reality. New York: The Viking, 1982, p. 129, tradução livre do original: "Os líderes mundiais declararam que querem ver o fim da corrida armamentista nuclear. Isso não aconteceu devido ao fato de que a liderança dos EUA e da URSS é temerosa em tomar qualquer ação porque seus cientistas de defesa e especialistas em 'inteligência' que constituem o coração de tal corrida sempre são capazes de gerar alarmismo sobre o que o outro lado está fazendo, ou pode estar fazendo".

40 OTT, David H. Public International Law in the Modern World. Londres: Pitman, 1987, p. 328, tradução livre do original: "Esse comprometimento [com a obrigação de se desarmarem] dos Estados nucleares ainda não foi cumprido e essa falha proveu um exemplo negativo para certos países que se regozijam nessa desculpa para não assinarem o tratado [TNP] e se movem aberta ou secretamente em direção ao desenvolvimento de suas próprias armas nucleares". Ver também LAFER, Celso. Comércio, desarmamento e direitos humanos - reflexões sobre uma experiência diplomática. 2. ed. São Paulo: Paz e Terra, 2006, p. 131: “Além disso, as implicações do novo status indiano e paquistanês podem e já estariam extrapolando a região e influindo em outra zona de tensão: o Oriente Médio. O recente teste pelo Irã de míssil de longo alcance passa a ser visto nesse novo contexto, e influi também nos cálculos de risco de Israel, uma vez que sua alçada de voo incluiria Tel Aviv, e sem dúvida nos da Turquia, rival regional do Irã na projeção de influência no ex-império soviético da Ásia Central". 
Sem essa resposta, partir-se-ia de uma mera presunção sobre haver ou não tal compatibilização, comprometendo qualquer objetividade deste trabalho ${ }^{41}$

41 Muito oportuno o alerta dado pelo pensador Bertrand Russel, ele próprio um ativista antinuclear, acerca da necessidade de se buscar quais são os fatos atinentes ao tema de estudo para não comprometê-lo com subjetividade excessiva. BERTRAND RUSSELL'S Message to the Future. BBC Face-to-Face 1959. Enviado em 5 out. 2010. Disponível em: https://www.youtube.com/watch?v=O8h-xEuLfm8. Acesso em: 13 dez. 2014. 


\section{ATUAL ESTÁGIO DA QUESTÃo NUCLEAR PARA FINS BÉLICOS - REALIDADE A SER SUPERADA?}

\subsection{Impacto inicial causado pelo advento das armas nucleares - dissuasão nuclear}

Como foi antecipado ao fim do tópico anterior, antes de se buscarem referências em À Paz Perpétua para a concretização do desarmamento nuclear, faremos uma breve consideração de fatos relativos à questão nuclear para identificar se, atualmente, ela atende ou não aos requisitos necessários para se erigir uma realidade pacífica.

É importante ressalvar que essa contextualização será bastante breve, já que, mais à frente, haverá uma descrição detalhada sobre a evolução histórica do surgimento e estabelecimento das armas nucleares como elementos distintivos do poderio bélico internacional, da corrida armamentista e do desenvolvimento normativo e institucional para se lidar com as armas atômicas.

Por ora, buscaremos apenas compreender em linhas gerais qual é o estado atual do desarmamento nuclear, para verificar se ele atende às exigências de uma sociedade apta à convivência em harmonia pacífica.

Um primeiro fator a se considerar para iniciar essas considerações envolve a unicidade das armas nucleares em relação ao seu potencial destrutivo, e como esse traço distintivo subverteu completamente as bases em que estavam assentadas as estratégias de defesa dos Estados.

O ineditismo do terror liberado com a explosão atômica era tal que não pode sequer ser compreendido pelas vítimas que conseguiram sobreviver ao ataque do dia 06/08/1945. É eloquente o relato de um sobrevivente, demonstrando a ignorância do que havia ocorrido:

A prefeitura e a polícia estavam denominando-a de 'bomba especial'. [...] Então, o Quartel General Imperial anunciou, posteriormente, que se tratava de um novo tipo de bomba. Nós já sabíamos que não era uma detonação ordinária. Apenas depois de três ou quatro dias é que eu escutei pela primeira vez as palavras 'bomba atômica' de um repórter' ${ }^{1}$.

HAMAI, Shinso. A-Bomb Mayor - Warnings and Hope from Hiroshima. Tradução de Elizabeth W. Baldwin. Hiroshima: Toppan, 2010, p. 47, tradução livre do original: "The prefecture and the police were calling it a 'special bomb'. [...] Then Imperial Headquarters later announced that it was a 'new type of 
De fato, iniciava-se, a partir daquele momento, uma nova era nas relações internacionais, uma vez que o novo tipo de armamento atribuía a seu detentor uma superioridade bélica e estratégica inigualável.

O já citado Abranches ${ }^{2}$ identifica com precisão essa ruptura gerada pela conquista da energia nuclear no ramo militar, quando afirma que "todas as armas novas repercutiram sobre o uso da força nas épocas em que apareceram, mas nenhuma era de molde a gerar uma situação antes inexistente: a certeza de que o gênero humano dispunha agora do poder de autodestruição".

Segundo Wight, rapidamente se pode afirmar que se tratava da arma absoluta ${ }^{3}$, dada a vantagem estratégica que representava.

Por essas razões é que se pode afirmar que a descoberta tecnológica do controle da energia nuclear para fins bélicos tornou, imediatamente, obsoleta a realidade até então conhecida.

Seu uso "modificou a evolução previsível do Direito Internacional e subverteu quase todos os princípios em que os Estados baseavam suas relações exteriores. [...] tornou obsoletos, de um só golpe, os conceitos dominantes em matéria de estratégia, de meios para causar danos ao inimigo, de represália, de limites de ação dos beligerantes, de uso lícito da força, de defesa nacional, de soberania dos Estados, de segurança coletiva, de desarmamento e de organização internacional" 4 . Exatamente por conta disso é que o desarmamento nuclear constitui tema tão controvertido, sendo praticamente impossível distinguir os aspectos políticos e jurídicos afetados por ele ${ }^{5}$.

Essa complexidade fica evidente porque, a despeito da destrutividade incontrolada que as armas nucleares causam, elemento que torna difícil legitimar juridicamente sua posse e uso, politicamente assumiram papel preponderante na definição estratégica das políticas de segurança dos Estados.

bomb'. We already knew it was no ordinary detonation. It was three or four days later that I first heard the words 'atomic bomb' from a newspaper reporter".

2 ABRANCHES, C. A. Dunshee de. Proscrição das armas nucleares. São Paulo: Freitas Bastos, 1964, p. 15.

3 WIGHT, M. A política do poder. Tradução de C. S. Duarte. Brasília: Editora Universidade de Brasília, 1985, p. 200. ABRANCHES, op. cit. p. 13.

Ibidem, p. 17. 
Ao serem assim avaliadas, como descreve Lafer', "sua retenção pelos Estados que as detêm segue dependendo, em última instância, do papel que estes a elas conferem em seus cálculos de segurança", papel tão decisivo que, mesmo depois do confronto bipolar cuja principal característica, como se verá, era a ameaça recíproca de destruição entre os EUA e a URSS, "as potências não se mostram dispostas a de fato desvalorizar o papel das armas nucleares em suas doutrinas".

O apelo do status político diferenciado atribuído pela detenção de arsenais nucleares, mesmo diminutos quando comparados com os obtidos pelas principais potências mundiais, acaba sendo um elemento incentivador para que demais Estados venham a flertar com o desenvolvimento de armas nucleares para si próprios.

Como exemplo mais recente, é comum verificar a iniciativa norte-coreana neste particular. Não apenas porque sua retórica e prática política em relação à questão nuclear têm visado especialmente à sua consolidação como poder regional frente à China e ao Japão, para não mencionar a vizinha do sul, mas, ainda, pelo poder de barganha internacional que angariou ao se retirar do Tratado de Não-Proliferação e assumir abertamente o desenvolvimento de um programa nuclear bélico:

Sem capacidade nuclear, a Coreia do Norte é um estado isolado com uma economia falida que não receberia nenhum respeito internacional. Mas, como uma provável potência nuclear, o país tem jogado 'pôquer nuclear' com uma coalisão de cinco nações que tentam desarmar seu programa por meios pacíficos: os EUA, Rússia, Japão, China e Coreia do Sul? .

É interessante notar, contudo, como os papéis se alternam nesse tipo de discussão, já que, décadas atrás, Estados internacionalmente reconhecidos como potências, como a

6 LAFER, Celso. Comércio, desarmamento e direitos humanos - reflexões sobre uma experiência diplomática. 2. ed. São Paulo: Paz e Terra, 2006, p. 129.

7 CIMBALA, Stephen J. Nuclear Weapons and Cooperative Security in the 21st Century - The New Disorder. New York: Routledge, 2010, p. 117, tradução livre do original: "Without a nuclear capability, North Korea is a politically isolated outlaw state with a bankrupt economy that would receive almost no international respect. But as an apparent nuclear power, North Korea has played nuclear poker with a five-nation coalition attempting to disarm its program by peaceful means: the U.S., Russia, Japan, China and South Korea". 
Inglaterra, identificando que se não adquirissem o controle de arsenais nucleares teriam ameaçado tal reconhecimento, buscaram igualmente seu desenvolvimento ${ }^{8}$.

Vê-se claramente que, para fins políticos, a justificação para a aquisição de armas nucleares é plenamente compreensível. Contudo, a questão torna-se controvertida, ao ponto de constituir impasse que já dura décadas, quando se tenta obter a mesma justificação sob o prisma jurídico.

Diversos princípios consagrados no Direito Internacional, especificamente no que concerne às normas que regulam os conflitos armados, evidenciam a questionável legalidade dos armamentos nucleares, sendo suficiente, nesse momento, apenas se referir à incapacidade de seus efeitos de atenderem à necessária discriminação entre combatentes e não combatentes; ao banimento de meios que causem sofrimento desnecessário; à dificuldade de garantir que países neutros não serão afetados pelos efeitos dos danos ambientais indiscriminados causados pela radiação liberada pelo seu uso ${ }^{9}$.

Para contornar esses obstáculos, é comum o os Estados nucleares defenderem-se alegando que, mesmo se o uso de tais armas fosse proibido, essa vedação não se estenderia à sua posse e alocação como uma estratégia política para coibir possíveis adversários.

Trata-se de uma das facetas da dissuasão nuclear, ou seja, "a habilidade de um Estado instilar em outros um complexo de inferioridade tamanho que estes acreditem que o primeiro é invencível. Debilitar psicologicamente um adversário é um meio seguro de prevenir que lance um ataque" ${ }^{10}$.

Ainda assim, permanece altamente questionável o argumento, como se verá em detalhe no segundo capítulo da terceira parte da dissertação, quando se analisará a Opinião Consultiva da Corte Internacional de Justiça sobre a legalidade do uso ou da ameaça de uso das armas nucleares, de 1996.

OTT, David H. Public International Law in the Modern World. Londres: Pitman, 1987, p. 326.

A análise sobre a licitude das armas nucleares será desenvolvida na terceira parte deste trabalho.

10 LOUKA, Ellie. Nuclear Weapons, Justice and the Law. Cheltenham: Edward Elgar, 2011, p. 4, tradução do original: The ability of a state to instill in others a complex of inferiority so that they believe that this state is undefeatable is the essence of deterrence. Psychologically debilitating an adversary is a sure way to prevent it from launching an attack". Existem diversas acepções para definir a dissuasão, todas com significados que, em relação aos efeitos práticos, são muito similares. Ver CIMBALA, Stephen J. Nuclear Weapons and Cooperative Security in the 21st Century - The New Disorder. New York: Routledge, 2010, p. 33-35. 
Vale antecipar, para avançarmos na presente avaliação do estado atual da questão nuclear, que, segundo $\mathrm{Ott}^{11}$, se trata de comportamento ilegal, porque mesmo "sem considerar se essa ameaça constitui uma violação do Artigo 2(4) da Carta da ONU, a dissuasão demanda, para ser crível, uma prontidão na possibilidade do uso dessas armas. Isso implica uma predisposição no lançamento de destruição em massa para prevenir a vitória do inimigo, enquanto as regulações de Haia não permitem que se recorra a qualquer meio de atacar o inimigo, ou seja, há circunstâncias em que um Estado deve estar preparado para aceitar a derrota no lugar de utilizar armamentos proibidos".

A polêmica em torno da dissuasão é ainda maior quando se refere à confrontação entre países ou blocos de países submetidos a alianças de segurança rivais, ambos os quais detentores de poderio nuclear bélico.

Com efeito, ao lado dos questionamentos decorrentes de aspectos jurídicos rapidamente antecipados nos parágrafos anteriores, nesse contexto, mesmo a justificação política assente na dissuasão torna-se questionável, uma vez que a mera posse de bombas nucleares como ameaça ou retórica política deixa de se prestar à garantia de uma mínima estabilidade, mas, diferentemente, torna-se um elemento altamente perturbador.

Essa realidade começou a se sedimentar quando, em 1949, a URSS realizou sua primeira explosão nuclear e se tornou a primeira a rivalizar com os EUA na questão nuclear. Aliada à disputa ideológica entre os dois, quase imediatamente uma corrida armamentista foi disparada em busca de hegemonia e contenção da ameaça representada pelo inimigo.

A partir desse momento, não tardou a se consolidar o conceito de dissuasão mútua: uma vez que nenhum dos lados saberia se o outro efetuaria um primeiro ataque nuclear, fazia-se necessário o desenvolvimento de meios eficazes e invulneráveis de retaliação ${ }^{12}$.

Ao constatar a mudança representada pela disputa equilibrada, e não mais pela preponderância estratégica em relação a Estados não nucleares, Bull ${ }^{13}$ identifica essa situação distinta não mais como dissuasão, mas como contenção nuclear recíproca.

11 OTT, David H. Public International Law in the Modern World. Londres: Pitman, 1987, p. 326. Tradução nossa do fragmento citado.

12 ZUCKERMAN, Solly. Nuclear Illusion and Reality. New York: The Viking, 1982, p. 44. 
Por seu ineditismo para definir as políticas estratégicas nas relações internacionais, esse conceito se assentava, de modo temerário, em experiências de conflitos anteriores cuja validade, na lida com essa nova realidade, não poderia ser assumida com segurança ${ }^{14}$.

O termo oficial para descrever essa nova doutrina estratégica foi cunhado por John Foster Dulles, em 1954, enquanto era o Secretário de Estado norte-americano, como "retaliação massiva, ou seja, [...] em ordem de dissuadir ou conter uma agressão, os Estados Unidos iriam 'depender primordialmente de sua imensa capacidade de retaliação instantânea pelos meios e nos alvos de sua própria escolha"” 15.

Rapidamente, essa política incentivou recíproca similar pelo lado soviético, determinando que as forças reunidas por cada um transformasse a guerra nuclear num ato de autodestruição ${ }^{16}$, estabelecendo verdadeiro impasse, também classificado como equilíbrio do terror que, longe de estabilizar as relações internacionais, transformou o período conhecido como a Guerra Fria num verdadeiro pesadelo constante, com a humanidade convivendo com a sempre presente ameaça de um iminente holocausto nuclear.

Esse elemento desestabilizador era fundado exclusivamente nas disputas de poder entre os dois blocos antagônicos, sem qualquer base moral ou jurídica ${ }^{17}$.

A partir do momento em que houve a consolidação de arsenais nucleares de tamanho considerável sob o controle de cada uma das potências rivais, elas pretenderam perenizar suas respectivas hegemonias, apenas confrontadas uma pela outra, lançando as bases, na década de 1960, do que veio a ser o Tratado de Não-Proliferação Nuclear (TNP), assinado em 1968 e que entrou em vigor em $1970^{18}$.

13 BULL, Hedley. A sociedade anárquica. Tradução de Sérgio Bath. São Paulo: Universidade de Brasília, 2002, p. 136.

14 STODDART, Kristan. Losing an Empire and Finding a Role - Britain, the USA, NATO and Nuclear Weapons, 1964-70. Hampshire: Palgrave Macmillan, 2012, p. 9.

15 ZUCKERMAN, Solly. Nuclear Illusion and Reality. New York: The Viking, 1982, p. 43.

16 BUNDY, Mcgeorge; CROWE JR., William J.; DRELL, Sidney D. Reducing Nuclear Danger - The Road Away from the Brink. New York: Council on foreign Relations Press, 1993, p. 16.

17 ABRANCHES, C. A. Dunshee de. Proscrição das armas nucleares. São Paulo: Freitas Bastos, 1964, p. 168-169.

${ }^{18}$ O Tratado atualmente conta com 93 signatários e 190 Estados partes: UNODA (United Nations Office for disarmament affairs). Treaty on the Non-Proliferation of Nuclear Weapons. Opened for signature at London, Moscow and Washington: 1 July 1968. Disponível em: http://disarmament.un.org/treaties/t/npt. Acesso em: 9 dez. 2014. 
Segundo Miniuci ${ }^{19}$, o TNP decorreu dessa nova concepção de poder, que implicava a necessidade de evitar sua propagação para consolidá-lo. Assim, era preciso rígido controle na transferência de conhecimentos e de materiais, sob pena de colocar-se em risco o status quo.

Certamente, seja por sua nomenclatura, ou até mesmo por previsões específicas, como a constante do art. VI, que determina a obrigação das nações nucleares de negociarem os termos para o desarmamento nuclear completo, o TNP foi divulgado como uma conquista na defesa dos interesses da humanidade.

Não é por outra razão que há quem reconheça que ele tenha desempenhado "função relevante pelo desarmamento, por ter resultado da constatação de que, sem a imposição de limites, a própria humanidade estaria em sério risco de ser eliminada da face da Terra" ${ }^{20}$.

Mesmo que se enxergue esse lado "positivo", uma marca inegável do TNP é seu viés discriminatório e o modo pelo qual se prestou à perpetuação da vantagem militar das cinco nações nucleares ${ }^{21}$.

Ainda assim, conforme será analisado no capítulo 2, da segunda parte deste trabalho, mesmo que seu objetivo inicial fosse escuso, no sentido de atender a metas políticas egoístas, tratou-se de uma evolução muito significativa, à medida que, mesmo imprecisa e vaga, a previsão da obrigação de as nações nucleares buscarem o desarmamento constitui uma verdadeira conquista, já que é utilizada como instrumento de pressão cada vez mais efetivo e concreto para que as cinco nações reconhecidamente nucleares atendam aos anseios dos países não detentores de armas atômicas.

Independente dessa questão que será retomada com o vagar necessário mais à frente, o fato é que estes são os traços centrais da política nuclear sedimentada ao longo do período da Guerra Fria: a dissuasão nuclear pela ameaça de destruição mútua, e o congelamento do poderio nuclear bélico entre poucos atores.

19 FERREIRA JÚNIOR, Geraldo Miniuci. O acordo nuclear Brasil-Alemanha. In: DANESE, Sergio França (Org.). Ensaios de História diplomática do Brasil. Brasília: Fundação Alexandre de Gusmão, 1989, p. 154. (Cadernos do IPRI, n. 2.)

20 MAGAlHÃES, José Carlos de. Uma introdução. In: MERCADANTE, Araminta de Azevedo; MAGAlHÃES, José Carlos de (Coord.). Solução e prevenção de litígios internacionais. São Paulo: NECIN - Projeto CAPES, 1998, p. 12.

21 RAMINA, Larissa; CUNHA FILHO, Valter Fernandes da. Segurança internacional. Curitiba: Juruá, 2013, p. 166. 


\subsection{Análise da dissuasão como elemento de construção}

A fragilidade das bases dessa política de segurança internacional era tamanha, que inúmeros indivíduos que assumiram cargos políticos ao longo daquele período tornaram-se grandes críticos de sua eficácia. Ao identificarem que, na realidade, possuir o arranjo político-institucional era perigoso por conta do efeito reverso de colocar o mundo à mercê de um jogo precário de disputa hegemônica, esses indivíduos passaram a criticar fortemente suas bases.

Robert Mcnamara, que foi Secretário de Defesa dos presidentes John F. Kennedy e Lyndon B. Johnson, neste particular, contrariando o argumento de que a ameaça de destruição recíproca possuía efeito dissuasivo em relação a agressões por meios convencionais, destacava o alto custo dessa estratégia - o inaceitável risco de um conflito nuclear $^{22}$. Segundo o ex-Secretário, esse risco torna-se inaceitável quando se analisa a precariedade das bases efetivas em que se assenta o equilíbrio do terror.

Como foi bem descrito por Abranches ${ }^{23}$, para que seja efetiva a prontidão de uma retaliação massiva, as decisões devem ser rápidas, quase que automáticas, "tomadas com base em elementos de informação fornecidos por engenhos automáticos, que nem sempre permitem recorrer a outros meios de esclarecimento, em caso de dúvida. Uma falha do radar, um erro de interpretação, uma súbita moléstia mental de um dos ocupantes de postos de comando, um defeito no sistema de comunicações, qualquer dessas hipóteses poderia vir a ser responsável pelo desencadeamento de uma hecatombe nuclear acidental".

Não fossem apenas essas possíveis falhas de consequências catastróficas, deve-se ainda destacar a enorme ameaça representada por falhas nos serviços de inteligência e informação. Ao informar equivocada ou incompletamente os responsáveis pela decisão de avançar com retaliação ao que se imagina um ataque, convencional ou nuclear, coloca-se em xeque toda a legitimidade do discurso sobre a posse das armas nucleares como meio de evitar conflitos.

Tome-se, apenas a título de ilustração, a Crise dos Mísseis, talvez um dos momentos mais perigosos em relação a uma escalada nuclear entre americanos e soviéticos:

22 McNAMARA, Robert S. In Retrospect - The Tragedy and Lessons of Vietnam. New York: Times Books, 1995, p. 343.

23 ABRANCHES, C. A. Dunshee de. Dunshee de. Proscrição das armas nucleares. São Paulo: Freitas Bastos, 1964, p. 137. 
Nós sabemos hoje, com base em consideráveis pesquisas americanas e russas, que os líderes políticos e militares que participaram na crise foram atormentados por percepções distorcidas e informações falhas, presunções infundadas, inteligência equivocada ou faltante, e atributos de personalidade dos tomadores de decisão que não contribuíam em nada para uma avaliação acurada ou uma tomada de decisão racional. ${ }^{24}$

É interessante, nesse sentido, a confissão do próprio McNamara:

Fomos informados pelo então equivalente ao Chefe de Estado Maior do Pacto de Varsóvia, General Anatoly Gribkov, que, em 1962, as forças soviéticas em Cuba possuíam não apenas ogivas nucleares instaladas em mísseis de médio alcance, mas também bombas e armas nucleares táticas. As armas táticas ${ }^{25}$ destinavam-se às forças de invasão americanas. $\mathrm{Na}$ época, a CIA afirmava que não havia ogivas nucleares na ilha. ${ }^{26}$

A gravidade dessa falha era terrível, uma vez que, mesmo que as forças americanas não estivessem equipadas com armas nucleares táticas, que haviam sido proibidas pelo próprio presidente, obviamente se houvesse um ataque nuclear contra as tropas americanas, os Estados Unidos responderiam na mesma medida, o que resultaria num sério desastre:

24 CIMBALA, Stephen J. Nuclear Weapons and Cooperative Security in the 21st Century - The New Disorder. New York: Routledge, 2010, p. 4, tradução do original: "The American and Soviet experiences during the Cold War are less encouraging in this regard than one might suppose. Take the avatar of Cold War confrontations: the Cuban missile Crisis. We know now, on the basis of considerable research by Americans and Russians, that the political and military leaders who participated in the crisis were bedeviled by misperceptions and misinformation, faulty assumptions, erroneous or missing intelligence, and personality attributes of decision makers that were noncontributory to accurate assessment or rational decision making".

25 As armas nucleares podem ser simploriamente distinguidas entre armas estratégicas e armas táticas. As primeiras representam aquelas com poder elevado de destruição, os instrumentos para a política de dissuasão nuclear destruidoramente recíproca, geralmente lançadas por mísseis balísticos intercontinentais, aviões e submarinos. As outras possuem menos potencial destrutivo, são menores, e de mais fácil logística de transporte e uso, geralmente pensadas para utilização em conflitos localizados, disparadas no próprio campo de batalha. Para uma descrição sucinta, cf. MORE, Rodrigo Fernandes. O desarmamento no sistema de segurança coletiva da ONU. 2005. Tese (Doutorado) - Faculdade de Direito, Universidade de São Paulo, São Paulo, 2002, p.169.

26 McNAMARA, Robert S. In Retrospect - The Tragedy and Lessons of Vietnam. New York: Times Books, 1995, p. 341, tradução livre do original: "We were told by the former Warsaw Pact chief of staff, Gen. Anatoly Gribkov, that in 1962 Soviet forces in Cuba possessed not only nuclear warheads for the intermediate-range missiles but nuclear bombs and tactical nuclear warheads as well. The tactical warheads were to be used against U.S. invasion forces. At the time, as I mentioned, the CIA was reporting no warheads on the island". 
"Não apenas nossas perdas em Cuba seriam devastadoras, e a ilha destruída, mas haveria ainda um elevadíssimo risco de confronto nuclear muito além de Cuba." ${ }^{27}$

Bull resume bem estas falhas que corroem a validade do argumento da ameaça de destruição recíproca como um elemento sólido, estável e pacífico para o estabelecimento das relações internacionais envolvendo as armas nucleares: vulnerável por questões tecnológicas e políticas; precário por acidente ou erro de cálculo, que são inevitáveis; ineficaz diante de guerras já deflagradas; apesar de a irracionalidade ser rara, não impede que um líder aja sabendo das consequências da retaliação; e não incrementa a segurança o mundo sem armas nucleares é mais seguro, ainda que aumente a possibilidade da ocorrência de guerras (potencialmente menos catastróficas) ${ }^{28}$.

É emblemático o posicionamento sobre a dissuasão nuclear refletido pelo Comitê de Segurança Internacional e Controle de Armamentos da Academia Nacional de Ciências dos EUA, em estudo estratégico divulgado em 1991. Ainda que tenha sido publicado em contexto marcado por extremo otimismo devido à desconstituição da União Soviética e o fim da Guerra Fria, não deixa de ser relevante o reconhecimento de que "em qualquer nível de força, o sucesso da dissuasão nunca pode ser plenamente assegurado. Essa é uma razão para a limitação do número de armas nucleares no mundo, limitando, assim, o pior cenário em caso da falência completa da dissuasão" 29.

Reforçando o quanto aqui se afirma sobre as críticas contra o risco imposto pelas armas nucleares, inclusive questionando sua própria utilidade prática em situações de conflito, há inúmeros outros exemplos igualmente simbólicos.

Solly Zuckerman, conselheiro científico do império britânico, em obra intitulada Ilusão e Realidade Nuclear, sintetiza esse entendimento contrário às armas nucleares, citando um diretor de pesquisa e engenharia de defesa do Pentágono:

27 McNAMARA, Robert S. In Retrospect - The Tragedy and Lessons of Vietnam. New York: Times Books, 1995, p. 341-342. Em artigo publicado no Estado de S. Paulo, Michael Dobbs afirma que o presidente parecia um cego tropeçando na escuridão, mal sabendo o que ocorria em torno dele (Como parar uma guerra nuclear. São Paulo, 11 abr. 2013. Caderno A, p. 14.).

28 BULL, Hedley. A sociedade anárquica. Tradução de Sérgio Bath. São Paulo: Universidade de Brasília, 2002, p. 144-146.

29 Committee on International Security and Arms Control - National Academy of Sciences. The Future of the U.S. - Soviet Nuclear Relationship. Washington: National Academy, 1991, p. 16, tradução livre do original: "at any level of force, the success of deterrence can never be fully assured. This is one reason for limiting the world's inventory of nuclear weapons, thus limiting the worst case consequences of the complete failure of deterrence". 
Aqueles que serviram como oficiais civis no Departamento de Defesa em qualquer nível por indicação presidencial [...] reconheceram a severa limitação da utilidade do poder militar, e os grandes riscos associados ao seu uso, assim como a triste necessidade de sua posse [...] quanto mais elevada fosse sua posição e, portanto, sua responsabilidade, mais eles chegaram à conclusão de que devemos procurar uma segurança nacional por outros meios além dos estritamente militares [...] urgentemente. ${ }^{30}$

Zuckerman segue em suas ilustrações destacando o posicionamento similar de Harold Macmillian, primeiro ministro britânico entre 1957 e 1963, assim como o de diversos outros líderes civis e militares ${ }^{31}$. É muito importante o registro que traz também sobre esse pensamento ser igualmente verificado entre os líderes soviéticos, conforme o relato do encontro que teve com o General Mikhail Milshetin, general e porta voz que representou a União Soviética nas negociações para o Tratado de Limitação de Armas Estratégicas (SALT, assinado em $1972^{32}$ ). Nessa ocasião, Zuckerman indagou qual era o posicionamento soviético com respeito à possibilidade real de uso das armas nucleares, ao que o general teria respondido:

O que é ensinado a seus soldados? Que as armas que eles possuem não são boas, que eles devem deixá-las e ir para casa? Os homens no topo da URSS entendem os incríveis perigos assim como os líderes de vocês. Ninguém pode vencer com base nas armas nucleares. [...] Nossa doutrina considera as armas nucleares como algo que nunca deve ser usado ${ }^{33}$.

30 BROWN, Harold. Race to Oblivion. New York: Simon \& Schuster, 1970, apud ZUCKERMAN, Solly. Nuclear Illusion and Reality. New York: The Viking, 1982, p. 120-121, tradução livre do original: "Those who have served as civilian officials in the Department of Defense at the level of Presidential appointment [...] have recognized the severely limited utility of military power, and the great risks in its use, as well as the sad necessity of its possession ... higher their position and, hence, their responsibility, the more they have come to the conclusion that we must seek national security through other than strictly military means $[\ldots]$ and urgently".

31 ZUCKERMAN, Solly. Nuclear Illusion and Reality. New York: The Viking, 1982, p. 44, 70-71.

32 SALT I. Interim agreement between the United States of America and the Union of Soviet Socialist Republics on certain measures with respect to the limitation of strategic offensive arms. May 1972. Disponível em: http://www.nti.org/media/pdfs/aptsaltI.pdf?_=1316712383. Acesso em: 15 dez. 2014.

33 ZUCKERMAN, op. cit., p. 74-75, tradução do original: “'What are your soldiers taught?', he asked, 'that weapons with which they are furnished are no good, and that they should lay down their arms and go home? The men at the top in the USSR understand the incredible dangers just as much as your leaders do. No one can win with nuclear weapons'. In an interview recorded in the New York Times of 28th August 1980, General Milshtein gave the Soviet view as follows: 'We believe that nuclear war will bring no advantage to anyone and may even lead to the end of civilization. And the end of civilization can hardly be called victory. Our doctrine regards nuclear weapons as something that must never be used. 
Poder-se-ia contra-argumentar que esses posicionamentos são limitados porque se referem a planos hipotéticos, e que, em caso de conflitos reais com efetivas chances de derrota, os Estados nucleares não hesitariam em utilizar armas nucleares, especialmente caso estivessem ameaçadas posições geopolíticas estratégicas no contexto do confronto bipolar que marcou a Guerra Fria.

A experiência concreta refuta essa crítica.

Conforme consta de interessante obra que trata da problemática nuclear, publicada em conjunto por Mcgeorge Bundy, assistente especial dos Assuntos de Segurança Nacional de 1961 a 1966; pelo Almirante William J. Crowe Jr., ex-presidente da Junta de Chefes de Estado e responsável pela junta de aconselhamento do presidente sobre Inteligência Estrangeira; e Sidney D. Drell, físico e professor da Universidade de Stanford, antigo conselheiro do governo americano em assuntos técnicos, de segurança nacional, armas e controle:

Todo Estado nuclear já esteve em Guerra, e quase todos foram derrotados, mas nenhum se valeu de armas nucleares. Adicionalmente, não há escola de pensamento, em qualquer estado-nuclear, que defenda que seria melhor utilizar a bomba do que aceitar um resultado não satisfatório. [...] depois de quarenta e oito anos em que ninguém efetuou um ataque com armas nucleares, o mundo possui uma forte tradição em relação ao seu não uso. ${ }^{34}$

Ilustrando concretamente as afirmações dos autores que estiveram "na linha de frente" ao atuarem nos órgãos diretamente relacionados à mobilização do poderio bélico norte-americano, Hobsbawm ${ }^{35}$ elenca três ocasiões em que as potências nucleares não atingiram seus objetivos militares e, ainda assim, não utilizaram armas nucleares: os EUA quando da intervenção na Coreia em 1950; novamente os EUA, no Vietnã; e a URSS, que

34 BUNDY, McGeorge; CROWE JR., William J.; DRELL, Sidney D. Reducing Nuclear Danger - The Road Away from the Brink. New York: Council on foreign Relations Press, 1993, p. 8, tradução livre do original: "Every country with nuclear weapons has been at war, and most of them have been losers at war, but none has resorted to nuclear warheads. Moreover there is no significant school of thought, in any nuclear-weapon state, that argues that it would have been better to use the bomb than to accept this or that unsatisfactory result. [...] After forty-eight years in which no one has attacked anyone with nuclear weapons, the world has a strong tradition for their non-use".

35 HOBSBAWM, Eric. Era dos extremos. 2. ed. Tradução de Marcos Santarrita. São Paulo: Companhia das Letras, 1995, p. 234-235. 
se retirou do Afeganistão em 1998, após oito anos nos quais forneceu ajuda militar ao governo para combater guerrilhas locais.

Ironicamente, conclui o historiador que, "em suma, o material caro e de alta tecnologia da competição das superpotências revelou-se pouco decisivo".

Mesmo que se pretendesse, ainda assim, insistir no argumento da validade da dissuasão, afirmando-se que esses três conflitos não permitiram o uso de armas nucleares porque os alvos estariam protegidos pelo guarda-chuva nuclear do bloco adversário, é muito importante notar que, na questão coreana, o mundo ainda não estava marcado pela equiparação de forças nucleares americanas e soviéticas.

Novamente é incontestável recorrer a quem esteve nos gabinetes, ocupando posições estratégicas sobre o tema. McNamara ${ }^{36}$, nesse sentido, afirma que, apesar de as forças americanas estarem perigosamente ameaçadas durante a Guerra da Coreia por duas vezes, os EUA não utilizaram armas nucleares. Ele lembra que, à época, tanto a Coreia do Norte quanto a China não dispunham de capacidade nuclear, e que a capacidade soviética era desprezível.

Com base nessas constatações é que o autor se posiciona de maneira contundente pela necessidade de se lutar pelo retrocesso a um mundo sem armas nucleares, reconhecendo que a manutenção dos arsenais impõe o risco de seu uso, que não há risco militar que justifique seu uso, e que haveria um crescente apoio político a esse reconhecimento ${ }^{37}$. Ainda mais importante é a conclusão a que ele chega a seguir:

Nosso argumento leva à conclusão de que o uso militar das armas nucleares está limitado apenas à dissuasão para evitar que um oponente as utilize. Portanto, se nosso oponente não possuir armas nucleares, não há necessidade de que nós as possuamos ${ }^{38}$.

Verifica-se, portanto, que a política da dissuasão é refutada pelos próprios indivíduos que a testaram na prática. Exatamente por sua experiência é que, por dedução lógica e pela

36 McNAMARA, Robert S. In Retrospect - The Tragedy and Lessons of Vietnam. New York: Times Books, 1995, p. 342.

37 Ibidem, p. 338.

38 Ibidem, p. 342, tradução livre do original: "Our argument leads to the conclusion that the military use of nuclear weapons is limited to deterring one's opponent from their use. Therefore, if our opponent has no nuclear weapons, there is no need for us to possess them". 
percepção da barbaridade que as armas nucleares representam, eles formularam o conceito central da maneira mais eficaz de lidar com a questão nuclear - não pelo controle de seus possuidores, mas pelo seu completo banimento.

Faltava, contudo, vontade política para que os Estados nucleares abdicassem de seu poderio em prol de uma realidade mais adequada a valores de convivência pacífica. Acreditava-se que essa relutância seria determinada pela bipolaridade que marcara a realidade da Guerra Fria, formalmente finalizada apenas em 1991, e que, numa nova realidade política, não haveria mais a necessidade da posse desses arsenais.

\subsection{Breve otimismo suplantado por novas ameaças}

Esperava-se, especialmente das principais potências nucleares, que, ao passo que findasse aquela rivalidade ideológico-política, haveria uma gradual evolução rumo ao desarmamento nuclear efetivo.

Conforme ficou estampado nas análises publicadas naquele período imediato do pósGuerra Fria, acreditava-se que

ambos os governos teriam muitos ganhos caso lidassem com essa empreitada como uma conquista compartilhada na redução do perigo nuclear. Eles angariariam apoio e reforço internacional caso mantivessem como meta uma prática visível e sustentável de sua própria redução bilateral de armamentos, abertura e cooperação política, elementos indispensáveis para sua participação como líderes - embora nunca os únicos líderes - num esforço mais amplo contra o perigo nuclear. ${ }^{39}$

Segundo o já mencionado estudo publicado pelo Comitê de Segurança Internacional e Controle de Armamentos da Academia Nacional de Ciências dos EUA, “o fim da Guerra

39 BUNDY, Mcgeorge; CROWE JR., William J.; DRELL, Sidney D. Reducing Nuclear Danger - The Road Away from the Brink. New York: Council on foreign Relations Press , 1993, p. 40-41, tradução livre do original: "Both governments will gain from treating this whole enterprise as a shared undertaking in the reduction of nuclear danger. They will be reinforced in this basic approach if they bear in mind that the visible and sustained practice of their own bilateral arms reduction, openness, and political cooperation is indispensable to their effective participation as leaders - though never the only leaders - in the broader international effort against nuclear danger". 
Fria propiciava tanto incentivo quanto oportunidade para se examinar de uma maneira renovada os objetivos da política das armas quanto à missão das armas nucleares" 40 .

Nesse sentido, uma vez que as armas nucleares não possuiriam mais o papel de estabilização ou de instrumentos de apoio para a manutenção do status quo que mantinham durante a Guerra Fria, era esperado das duas principais potências que assumissem o papel condizente de liderar esforços pelo desarmamento para liderar efetivamente o controle da proliferação nuclear ${ }^{41}$.

Esse papel era esperado porque apenas se fossem atingidos os objetivos relacionados ao controle "vertical" das armas nucleares (diminuição dos estoques de ogivas e de suas respectivas forças), as duas nações obteriam credibilidade para liderar outros países nucleares no controle "horizontal" das armas nucleares, ao limitarem sua proliferação ${ }^{42}$.

Não foi essa, contudo, a resultante daquela mudança. Num primeiro momento, simplesmente foram mantidas as posturas previamente estabelecidas, com pequenas sinalizações de reduções bilaterais nada efetivas para uma significativa mudança nas premissas em que estavam fundadas as políticas de segurança internacional:

\begin{abstract}
A essência da relação que marcou o pós-Guerra Fria remanesceu marcada pelo modelo de orientação da dissuasão resumida pela ameaça mútua. Um equilíbrio estável do terror nuclear entre Washington e Rússia eram o objetivo assumido do acordo START. [...] A razão de tanto os EUA quanto a Rússia pretenderem, naquele período, lançar um primeiro ataque nuclear em qualquer alvo, incluindo um ao outro, era um tema que recebia pouquíssima atenção ou reconsideração ${ }^{43}$.
\end{abstract}

Esse comportamento teve o efeito de alimentar um sentimento de insatisfação dos estados não nucleares, que reivindicavam ou o cumprimento da obrigação das potências

40 Committee on International Security and Arms Control - National Academy of Sciences. The Future of the U.S. - Soviet Nuclear Relationship. Washington: National Academy, 1991, p. 15.

41 CIMBALA, Stephen J. Nuclear Weapons and Cooperative Security in the 21st Century - The New Disorder. New York: Routledge, 2010, p. 1.

42 Ibidem, p. 6.

43 Ibidem. p. 35, tradução livre do original: "the essence of that post-Cold War relationship remained locked within a deterrence-oriented model that resembled Cold War redux. A stable balance of nuclear terror between Washington and Moscow was the assumed object of START. [...] Why either America or Russia would launch a nuclear first strike at anyone, including each other, was a subject that received very little exposition or rethinking”. 
nucleares de se desarmarem conforme previsto no art. VI, do TNP, ou o direito de eles virem a desenvolver seus próprios arsenais nucleares.

As esperanças foram completamente perdidas principalmente a partir de 2001, em grande parte pela reação americana aos ataques terroristas de 11 de setembro ${ }^{44}$. A partir daquele momento, a relutância contra a obrigação de assumir efetivamente uma agenda em prol do desarmamento transformou-se num acirramento das estratégias de segurança, especialmente a norte-americana, em relação à política nuclear.

Jayantha Dhanapala, que presidiu a conferência de revisão do TNP de $1995^{45}$, em obra colegiada publicada pela Universidade da ONU, identificou os motivos que determinavam o retorno da questão nuclear para o centro das atenções internacionais. Além do terrorismo, da retomada de investimentos em projetos energéticos focados na matriz nuclear, ele destacava a mudança nas doutrinas nucleares das potências centrais, que passaram a admitir o uso preventivo daquelas armas mesmo contra estados não nucleares: "Essa mudança ocorreu durante a Administração de George W. Bush e foi seguida pelo desenvolvimento de armas nucleares projetadas para uso efetivo no campo de batalha" ${ }^{46}$.

Esse reposicionamento não se resumiu ao alarmismo que marcou a reação imediata dos EUA aos ataques ocorridos em 11 de setembro de2001. Conforme consta do plano de segurança nacional e armas nucleares para o século XXI, publicado pelo Departamento de Defesa em 2008, esse acirramento permaneceu como marca constante dos anos que se seguiram:

As armas nucleares continuam a representar o maior poder de dissuasão que mantém a segurança nacional dos EUA. [...] As armas nucleares dos EUA dissuadem adversários potenciais da ameaça ou do uso de armas de destruição em massa contra os Estados Unidos, suas forças armadas estacionadas em escala global, seus aliados e amigos. Na ausência desse "guarda-chuva" nuclear, alguns aliados não nucleares poderiam sentir a

LOUKA, Ellie. Nuclear Weapons, Justice and the Law. Cheltenham: Edward Elgar, 2011, p. 45.

45 O TNP, sua estrutura, inclusive os mecanismos de revisão, serão objeto de análise no capítulo 2 , da segunda parte deste trabalho.

46 DHANAPALA, Jayantha. Foreword. In: BOULDEN, James; THAKUR, Ramesh Chandra; WEISS, Thomas George (Coords.).The United Nations and Nuclear Orders. Tokyo: United Nations University, 2009 , p. xiv. Ver divulgação do Jornal Nacional sobre planos concretos norte-americanos de utilizar as armas nucleares na "guerra contra o terror", deliberadamente elencando países passíveis de serem atacados nuclearmente. JORNAL NACIONAL: EUA queriam usar armas nucleares em 2002. Jornal (da Rede Globo) de 9 mar. 2002. Enviado em 1 jul. 2011. Disponível em: https://www.youtube.com/watch?v=THm0Pe-Bwjs. Acesso em: 24 nov. 2014. 
necessidade de desenvolver suas próprias capacidades nucleares. [...] A manutenção de um arsenal nuclear seguro, protegido e respeitado e sua infraestrutura de apoio é de importância vital para os interesses norteamericanos. [...] Ainda que não adequados para lidar com todos os desafios do século XXI, as armas nucleares permanecem como elemento essencial na estratégia moderna. [...] Os Estados Unidos precisarão manter sua força nuclear pelo futuro que vislumbramos. [...] Essas características indicam claramente a continuidade da relevância das armas nucleares, e a necessidade de se manter uma capacidade nuclear americana viável muito adiante durante o século XXI. ${ }^{47}$

Comprovando que se tratava de um retrocesso perene à retórica fundada no medo como elemento legitimador da manutenção das armas nucleares ${ }^{48}$, já em 2010, sob a presidência de Barack Obama, notadamente com políticas externas menos belicistas do que as de seu antecessor, foi publicada a Estratégia de Segurança Nacional, com previsões similares 49 .

Essa política nuclear, como já era esperado pelo papel desempenhado pelos EUA nesse tema, acabou sendo refletida pelas demais nações nuclearmente reconhecidas pelo $\mathrm{TNP}^{50}$.

A guinada política que frustrou o otimismo existente no período imediatamente posterior ao término da Guerra Fria refletiu-se diretamente na questão da proliferação nuclear, com os inúmeros efeitos negativos que essa realidade traria para a estabilidade internacional.

Não é possível ignorar que o regime ${ }^{51}$ estabelecido pelo TNP é desigual e discriminatório, ao reservar a alguns poucos Estados prerrogativas quanto à possibilidade

47 U.S.A. Department of Defense and Department of Energy of United States of America. National Security and Nuclear Weapons in the 21st Century. Feb. 2008. Disponível em: http://www.defense.gov/news/nuclearweaponspolicy.pdf. Acesso em: 16 nov. 2014.

$48 \mathrm{Na}$ quarta parte deste trabalho será analisado como o contexto político tem afetado o desarmamento nuclear.

49 U.S.A. Seal of the President of the United States. National Security Strategy. May 2010. Disponível em: http://www.whitehouse.gov/sites/default/files/rss_viewer/national_security_strategy.pdf. Acesso em: 16 nov. 2014.

50 REGEHR, Ernie. The Security Council and Nuclear Development. In: BOULDEN, James; THAKUR, Ramesh Chandra; WEISS, Thomas George (Coords.). The United Nations and Nuclear Orders. Tokyo: United Nations University, 2009, p. 32.

51 Rodrigo Fernandes More traz interessante definição de regime, que utilizaremos para ilustrar o regime estabelecido pelo TNP: "Um regime consiste numa moldura de regras ou expectativas, estabelecidas num acordo formal ou informal, que os Estados criam para regular suas relações numa determinada matéria na ausência de uma autoridade superior. Um regime se estabelece diante dos altos custos para consecução de objetivos, ou porque os Estados percebem vantagens na cooperação sobre interesses comuns, reduzindo 
de possuírem armas nucleares. Assim, a proliferação horizontal, a rigor, poderia ser considerada como um efeito da promoção da justiça internacional, caso essas prerrogativas fossem ampliadas a todos os Estados. Bull encara com franqueza a questão ao afirmar que "no sentido representado pela igualdade com respeito à posse de armas nucleares, a justiça internacional só pode ser alcançada plenamente mediante o completo desarmamento nuclear ou, então, por um sistema que tornasse disponíveis essas armas a todos os estados ou blocos de estados”. O autor, contudo, não advoga a proliferação desenfreada, ressalvando a complexidade dessa "área em que os objetivos da ordem internacional e da justiça internacional entram em conflito ${ }^{52}$.

É pertinente ainda o destaque que dá para a dicotomia existente entre as visões das principais potências e dos países em desenvolvimento, afirmando que enquanto os primeiros preocupam-se primordialmente com a ordem para justificar as suas políticas, os últimos preocupam-se mais com a realização da justiça na comunidade internacional, mesmo a custo da desordem ${ }^{53}$.

Mesmo que com acidez exagerada, a bandeira dos que apontam a injustiça do arranjo internacional em relação à questão nuclear é perfeitamente resumida por Abdul Qadeer Khan, o cientista paquistanês responsável pelo desenvolvimento secreto do programa nuclear daquele país, conforme carta que publicou na Der Spiegel:

quero questionar a atitude dos americanos e dos ingleses. Por acaso esses safados foram designados por Deus como guardiães do mundo com direito a acumular milhares de ogivas nucleares e autorizados por Deus a realizar explosões todos os meses? Nós, se começamos um programa modesto, somos satãs, somos o diabo. ${ }^{54}$

em ambas as situações seus custos operacionais. Um regime não é um sistema decisório, muito embora possa fomentar fóruns formais ou informais de negociação, mas tem como principal objetivo atender aos interesses concretos e primários de segurança interna de seus membros”. MORE, Rodrigo Fernandes. $O$ Desarmamento no sistema de segurança coletiva da ONU. 2005.Tese (Doutorado) - Faculdade de Direito, Universidade de São Paulo, São Paulo, 2002, p. 20.

52 BULL, Hedley. A sociedade anárquica. Tradução de Sérgio Bath. São Paulo: Universidade de Brasília, 2002, p. 273-274.

53 Ibidem, p. 91.

54 LANGEWIESCHE, William. O bazar atômico - a escalada do poderio nuclear. Tradução de José Viegas. São Paulo: Companhia das Letras, 2007, p. 113. 
Apesar de atacar a injustiça existente no regime atual de não proliferação, parece-nos que, segundo as alternativas aventadas por Bull, o espraiamento indiscriminado de arsenais nucleares mundo afora representa o pior cenário.

O efeito seria muito negativo porque, conforme pudemos observar, mesmo quando o jogo de poder marcado pela dissuasão nuclear era praticado por poucos atores, notadamente pelas duas potências hegemônicas, já havia uma série de fatores que indicavam a fragilidade e precariedade da arquitetura que sustentava o equilíbrio.

Transpor essa realidade para um tabuleiro internacional pulverizado representaria enorme risco de falha na lógica da dissuasão, uma vez que

dificilmente se conseguiria repetir o precário equilíbrio então obtido com a estratégia de destruição mutuamente assegurada, porque os novos Estados nuclearmente armados não dispõem da estrutura ou da experiência para evitar erros de julgamento e detonações não autorizadas, sem falar nos sistemas de segurança necessários para garantir a integridade dos arsenais. ${ }^{55}$

Lafer abordou com precisão essa avaliação dos enormes riscos que a ampliação de Estados nucleares traria para o funcionamento da política nuclear fundada na dissuasão, destacando um inaceitável incremento de irracionalidade e imprevisibilidade em sua dinâmica:

O próprio aumento no número de Estados detentores da capacidade nuclear é motivo de preocupação, não apenas pela ampliação física e de facto do clube nuclear, mas também pela introdução de armas nucleares em um novo contexto estratégico, sujeito a uma racionalidade que pode vir a ser distinta daquela que até hoje se aplica às hipóteses de uso dessas armas. No mundo bipolar regido pela dissuasão estratégica, ambos os lados operavam com base no mesmo cálculo de racionalidade - ou irracionalidade. Já num contexto em que os cenários de uso dessas armas tornam-se mais difusos e sujeitos a contingências de conflitos entre

55 SAMPAIO, Maria Feliciana Nunes Ortigão de. O Tratado de Proibição Completa dos Testes Nucleares $(C T B T)$ : Perspectivas para sua entrada em vigor e para a atuação diplomática brasileira. Brasília: Alexandre de Gusmão, 2012, p. 46-47. 
Estados rivais regionais, tal cálculo pode mostrar-se distinto - e mais imprevisível. $^{56}$

É por essas razões que diversos especialistas manifestavam extremo ceticismo em relação ao regime de dissuasão recíproca no novo contexto ${ }^{57}$, havendo inclusive afirmações no sentido de que a probabilidade de uma catástrofe nuclear aumentaria com certeza matemática ${ }^{58}$.

More, na sua já citada tese sobre desarmamento internacional, resume de maneira interessante esse contexto, afirmando que a política da destruição mutuamente assegurada não mais se caracterizaria pelo "equilíbrio do terror", mas por um "desequilíbrio do terror" devido à imprevisibilidade e risco causados seja por novos atores estatais envolvidos considerados proliferadores, seja pela duvidosa garantia de segurança do chamado "guarda-chuva de proteção" do TNP (1968), que jamais foi testada, ou, ainda, pelas ameaças de atores não-estatais, como o terrorismo internacional, este apoiado, omissiva ou comissivamente, por Estados párias. ${ }^{59}$

Essas graves ameaças representadas pela proliferação nuclear é que permitem afirmar que a manutenção do menor número possível de estados nuclearmente armados é um interesse mundialmente compartilhado, e que, mesmo havendo motivos políticos para que as nações busquem desenvolver armas nucleares, ao fim e ao cabo o término da proliferação é o desejo de todos os Estados ${ }^{60}$.

\subsection{Desarmamento como solução - barreiras históricas}

Conforme foi possível depreender da descrição sobre as fragilidades que existem na política da ameaça nuclear recíproca como fundamento de um convívio pacífico, especialmente no cenário ameaçador de aumento da proliferação nuclear horizontal, é

56 LAFER, Celso. Comércio, desarmamento e direitos humanos - reflexões sobre uma experiência diplomática. 2. ed. São Paulo: Paz e Terra, 2006, p. 132. Ver ainda: BULL, Hedley. A sociedade anárquica. Tradução de Sérgio Bath. São Paulo: Universidade de Brasília, 2002, p. 273.

57 CIMBALA, Stephen J. Nuclear Weapons and Cooperative Security in the 21st Century - The New Disorder. New York: Routledge, 2010, p. 11.

58 SCHMIDT, H. Defense or Retaliation. Londres: Oliver and Boyd, 1962, apud ZUCKERMAN, Solly. Nuclear Illusion and Reality. New York: The Viking, 1982, p. 81-82.

59 MORE, Rodrigo Fernandes. O desarmamento no sistema de segurança coletiva da ONU. 2005. Tese (Doutorado) - Faculdade de Direito, Universidade de São Paulo, São Paulo, 2002, p. 31.

60 BUNDY, McGeorge; CROWE JR., William J.; DRELL, Sidney D. Reducing Nuclear Danger: The Road Away from the Brink. New York: Council on foreign Relations Press, 1993, p. 56. 
possível caracterizar "o quadro nuclear internacional como desestimulador para se atingir a harmonia desejável entre todas as nações do mundo" ${ }^{61}$.

Nesse sentido, "no lugar do controle da proliferação das armas atômicas, o melhor seria a proscrição desse tipo de arma, o que dissiparia qualquer dúvida quanto à possibilidade de eclosão de um não-desejado conflito nuclear", ${ }^{\text {, }}$.

Tal é a conclusão porque, apesar do tempo que o processo de abolição das armas nucleares possa levar, sem essa abolição, as avaliações apontam que será impossível evitar

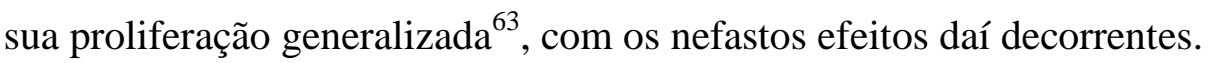

O já citado Vieira de Mello, em sua análise sobre a atualidade das reflexões políticas de Kant, acaba sintetizando bem o quanto aqui se afirma, quando considera

ingênuo pensar que uma determinada sociedade política poderia constituir-se, sobreviver e desenvolver-se dentro de uma sociedade internacional marcada pela insegurança, competição e hostilidade. Não há razão particular na des-razão coletiva. E vice-versa ${ }^{64}$.

Nesse exato sentido, Lafer, reconhecendo as dificuldades e riscos decorrentes de uma realidade em que se deverá conviver por tempo indeterminado com a prática do terror desenvolvida ao longo da Guerra Fria, posiciona-se igualmente pela necessidade de suplantá-la por meio do desarmamento nuclear, "única forma de efetivamente superar o dualismo entre Estados possuidores e não-possuidores de armas nucleares" ${ }^{\text {65 }}$.

Ainda mais marcante é constatar que o próprio John Foster Dulles - que pode ser considerado, como foi observado acima, um dos primeiros idealizadores da política que

61 MAGALHÃES JÚNIOR, Japy Montenegro; MARQUES, Fernando Mário Rodrigues. A proliferação nuclear. Revista de Administração Pública, Rio de Janeiro, v. 12, n. 4 , p.173-197, out./dez.1978. Disponível em: 〈www.spell.org.br/documentos/download/15540〉. Acesso em: 15 nov. 2014, p. 193.

62 Ibidem, p. 174.

63 CIMBALA, Stephen J. Nuclear Weapons and Cooperative Security in the 21st Century - The New Disorder. New York: Routledge, 2010, p. 26. Perspicaz e simples a constatação do mesmo autor quando afirma que( p. 5, tradução livre do original em inglês): "vivemos ainda no mundo de Tucídides em que Estados lutam por medo, honra e interesse. E eles farão o mesmo amanhã - seria melhor, então, que eles lutassem sem armas nucleares à disposição".

64 MELLO, Sérgio Vieira de. História filosófica e História real: atualidade do pensamento político de Kant. In: MARCOVITCH, Jacques (Org.). Sérgio Vieira de Mello - pensamento e obra. São Paulo: Edusp / Saraiva, 2004, p. 45.

65 LAFER, Celso. Comércio, desarmamento e direitos humanos - reflexões sobre uma experiência diplomática. 2. ed. São Paulo: Paz e Terra, 2006, p. 125-126. 
acabou dominando a prática internacional da constante ameaça de destruição nuclear contemplou, anos depois, como uma meta a longo prazo fundada em questões morais e geopolíticas, a abolição geral das armas nucleares ${ }^{66}$.

É nesse contexto que se evidencia a enorme complexidade da questão do desarmamento nuclear, já que toda a base político-institucional das relações internacionais a esse respeito reitera cotidianamente a prática da dissuasão. Tanto é assim que, conforme se verá na terceira parte do trabalho, apesar do intenso e diversificado aparato normativo que trata das armas nucleares, suas limitações, e o controle de sua proliferação, não houve, até hoje, a consagração de uma norma internacional que afirme sua ilegalidade ${ }^{67}$.

Por ora, podemos afirmar que a controvérsia em torno do desarmamento encontra-se no confronto entre a necessidade de se obtê-lo, e a prática internacional consolidada que insiste em refutá-10 ${ }^{68}$.

Justamente por se situar nesse complexo contexto é que é recorrente se referir ao desarmamento nuclear como um tema utópico reservado a idealismos impraticáveis:

Assim, a discussão acadêmica sobre a extensão do artigo VI do TNP (1968), que obrigaria a um desarmamento nuclear geral (de todos os Estados), queda sem sentido prático, ou, numa interpretação realista, torna-se impossível. As armas nucleares representam o máximo em poder destrutivo, portanto o máximo poder militar de dissuasão bilateral (da certeza da destruição mútua), das quais os Estados, de fato, jamais abdicarão sob o simples argumento do risco da aniquilação unilateral. ${ }^{69}$

66 GADDIS, John Lewis. The Unexpected John Foster Dulles: Nuclear Weapons, Communism and the Russians. In: IMMERMAN, Richard H. John Foster Dulles and the Diplomacy of the Cold War. New Jersey: Princeton University, 1990, p. 58.

67 A necessidade ou não de uma consagração por meio de um tratado com essa previsão será objeto de ponderação detalhada quando se avaliar a Opinião Consultiva da Corte Internacional de Justiça sobre a ilegalidade do uso ou da ameaça de uso de armas nucleares, tema do segundo capítulo da terceira parte deste trabalho.

68 BUNDY, Mcgeorge; CROWE JR., William J.; DRELL, Sidney D. Reducing Nuclear Danger - The Road Away from the Brink. New York: Council on Foreign Relations Press, 1993, p. 5-6, tradução livre do original em inglês: "infelizmente, ninguém sabe como abolir as armas nucleares, mas a mudança dramática do quanto necessitamos delas impõe enormes alterações nos limites que podemos aceitar no tocante ao tamanho dos arsenais e ao seu uso, e essa diferença afeta, por sua vez, o que os demais podem decidir".

69 MORE, Rodrigo Fernandes. O desarmamento no sistema de segurança coletiva da ONU. 2005. Tese (Doutorado) - Faculdade de Direito, Universidade de São Paulo, São Paulo, 2002, p. 326-327. 
Contudo, conforme exposto no capítulo anterior, deve-se tentar combater o ceticismo em relação ao desarmamento nuclear, para não comprometer quaisquer possibilidades de se construírem, gradativamente, meios, sejam eles políticos-institucionais, sejam eles jurídicos, que, numa larga escala evolutiva, lançariam as bases necessárias, mesmo mínimas, para suplantar uma realidade que já se provou contrária aos ideais mais elevados pautados pela evolução racional da humanidade.

Não se estão aqui subestimando as dificuldades enfrentadas em torno da questão, nem tampouco há uma presunção desmesurada sobre a possibilidade de se propor como superar os obstáculos à meta do desarmamento. O presente trabalho nem de longe se propõe a apontar qual é a saída para o impasse. Diferentemente, como já foi antecipado, a proposta é de tão somente buscar no projeto kantiano, especificamente no ensaio $\grave{A} P a z$ Perpétua, meios de se oxigenar a análise, evitando o tautologismo que marca as relações internacionais, conforme a boa descrição de Casella ${ }^{70}$.

Caso se optasse pela resignação, não haveria por que avaliar juridicamente a questão do desarmamento nuclear, sua dinâmica, e possíveis meios de se obter sua evolução. Exatamente para evitar essa consolidação e perenização de uma realidade inaceitável, é que se optará pela abordagem do tema pela visada da utopia, no sentido de uma visão de futuro $^{71}$, conforme, aliás, se posiciona Kant em relação ao seu projeto de paz perpétua.

É possível identificar, de antemão, a similitude em relação às críticas enfrentadas tanto pelo projeto kantiano, quanto pelo tema do desarmamento nuclear. Assim como são inúmeros os exemplos que contrariam a possibilidade de se considerar viável haver um banimento de armas atômicas num breve período de tempo, sendo também inúmeras as frustrações das iniciativas em busca desse objetivo, do mesmo modo são verificadas, ao longo da história, barreiras aparentemente intransponíveis para a consolidação de uma realidade pacífica internacional como aquela imaginada por $\mathrm{Kant}^{72}$.

70 CASELLA, Paulo Borba. Fundamentos do Direito internacional pós-moderno. São Paulo: Quartier Latin, 2008, p. 933-934.

71 LAMAZIĖRE, Georges. Desarmamento nuclear e hegemonia - em busca de um novo paradigma. Revista Estudos Avançados, Instituto de Estudos Avançados da Universidade de São Paulo. Disponível em: 〈www.iea.usp.br/artigos〉. Acesso em: 9 dez. 2014, p. 7.

72 CASELLA, Paulo Borba. Pax perpetua - a Review of the Concept from the Perspective of Economic Integration. In: CASELLA, Paulo Borba (Coord.). Dimensão internacional do Direito - Estudos em homenagem a G. E. do Nascimento e Silva. São Paulo: LTr, 2000, p. 71. 
Para lidar com as frustrações em relação aos dois temas, segundo o projeto do filósofo alemão, na síntese de Patrick Riley, é indispensável atribuir à moralidade papel decisivo que, no futuro, acabaria preponderando sobre a política e o direito:

a moralidade constitui o valor supremo, então a política e a justiça pública apenas podem ser consideradas como instrumentos para possibilitar a moralidade. [...] A distinção entre legalidade e moralidade é, certamente, uma das questões mais importantes para Kant. Inobstante, ele almeja que política e moralidade irão, em algum ponto no futuro, aproximar-se. [...] Então, a política não irá mais exigir aquilo que a moral expressamente proíbe ${ }^{73}$.

Não parece aceitável, diante dessa síntese, que, ao se deparar com dados da realidade presente que contrariem esse ideal kantiano, a sociedade ignore por completo a necessidade de tentar pautar o comportamento exatamente pelo referencial do ideal a ser atingido. Honrar essa necessidade é o único meio de evitar que os problemas atuais sejam compreendidos por sua própria existência, ratificando-os e, numa postura conformada, inclusive legitimando-os.

Para evitar essa consequência negativa, que congela a história, impedindo avanços qualitativos, é que se compreende da melhor forma o projeto de Kant. Não como algo a ser defendido como possível atualmente, nem mesmo num longo prazo, mas como marco referencial de uma constante evolução. A paulatina e crescente observância das referências condizentes com a moral permitirá a consecução da realidade utópica da ordem cosmopolítica da Paz Eterna, em que os Estados entrarão voluntariamente em permanente equilíbrio, realidade em que não serão mais exigidos de seus cidadãos que sejam espiões, envenenadores ou traidores ${ }^{74}$.

Transpondo essas premissas para a problemática do desarmamento nuclear, verificarse-ia que os massacres causados pelos ataques nucleares contra Hiroshima e Nagasaki, e a própria ameaça de autodestruição irracional imposta pela política do equilíbrio do terror

73 PATRICK, Riley. Will and Political Legitimacy. Massachusetts: Harvard University, 1982, p. 128-133, tradução livre do original em inglês: "If a good will, or morality, is the only good, then politics and public legal justice can only be instrumental to the possibility of that good will. [...] The distinction between legality and morality is, of course, one of the most important in Kant. Nonetheless, he does seem to hope that politics and morality will, at some point in the future, draw closer together. [...] politics will no longer demand what morality positively forbids".

74 Ibidem, p. 133. 
que marcou o período da Guerra Fria, seriam os dados da experiência concreta que negariam, para os céticos, a validade da proposição do ideal kantiano. Uma vez mais recorremos a Bull para ilustrar as dificuldades inerentes à luta pela obtenção de um efetivo desarmamento nuclear, quando reconhece que o

contexto da ordem internacional é bastante desfavorável aos projetos que pretendem realizar a justiça cosmopolita ou mundial [...]. [por se tratarem de] questões que permanecem sob o controle dos estados e, na ausência de profundas mudanças na sociedade humana, eles não parecem interessados em abrir mão desse controle. ${ }^{75}$

Dessa forma, para enfrentar esse tema de modo minimamente propositivo, não resignado com a realidade da sociedade atual, submetida ao controle dos interesses dos estados, é indispensável que ele seja encarado de modo similar ao modo como é proposta a construção gradativa de uma realidade mais elaborada, conforme a concepção proposta por Kant em seu ensaio À Paz Perpétua.

Apesar da relutância dos detentores desse controle, não se pode ignorar que

a questão nuclear se inscreve, literalmente, como condição de sobrevivência humana e, neste sentido, põe-se o direito internacional pós-moderno para a construção da ordenação humana do mundo. A conscientização da necessidade será indispensável para que as limitações decorrentes da adoção e da implementação do arcabouço institucional e normativo internacional possa se tornar aceitável. ${ }^{76}$

É oportuno destacar a dedicatória de Zuckerman, em seu livro, a Harold Macmillian, primeiro ministro britânico entre os anos de 1957 a $1963^{77}$, citando sua insistência junto ao Presidente Eisenhower para que este concordasse com o banimento completo de testes nucleares, em 1959: "We ought to take risks for so great a prize. We might be blessed by

75 BULL, Hedley. A sociedade anárquica. Tradução de Sérgio Bath. São Paulo: Universidade de Brasília, 2002, p. 102-103.

76 ACCIOLY, Hildebrando; NASCIMENTO E SILVA, Geraldo E. do; CASELLA, Paulo Borba. Manual de Direito Internacional Público. 16. ed. São Paulo: Saraiva, 2008, p. 748. Ver ainda REZEK, Francisco. Direito Internacional Público - curso elementar. 13. ed. São Paulo: Saraiva, 2011, p. 426.

77 GOV.UK. History. Past Prime Ministers. Harold Macmillan. (Written by James Jink.) Disponível em: <https://www.gov.uk/government/history/past-prime-ministers/harold-macmillan> Acesso em: 8 nov. 2014. 
future ages as saviours of mankind, or we might be cursed like the man who made 'il gran rifuto", 78

É, pois, sob esse prisma que se analisará, no capítulo seguinte, em que medida o projeto À Paz Perpétua contribui para uma melhor abordagem do desarmamento nuclear, seja no sentido de uma norma moral que se apresenta como referência idealizada, seja por concretas proposições do ensaio kantiano que possuem interessantes implicações no tocante ao desarmamento.

Faz-se indispensável, antes de qualquer avanço, a precisa ponderação de Casella:

O teste de efetiva implementação, apesar de relevante [...], não deve ser tão inflexivelmente aplicado a conceitos filosóficos com pretensão de regular a prática dos estados [...] Não obstante nós não rebaixamos os padrões - e esperançosamente não deveremos fazê-lo -, ainda que a prática política desenvolva-se de maneira incipiente, consideravelmente abaixo dos padrões desejáveis ${ }^{79}$.

Não se pretenderá identificar, em absoluto, nos dados da atualidade, elementos idênticos aos constantes da proposição kantiana. Contudo, não se deixarão de apreender questões que, com uma aplicação não inflexível dessa teoria, possam ser bem compreendidas.

78 ZUCKERMAN, Solly. Nuclear Illusion and Reality. New York: The Viking, 1982, dedicatória introdutória. Para manter a homenagem, permitimo-nos manter o original, cuja tradução livre é a seguinte: "Nós devemos assumir os riscos por uma compensação tão relevante. Nós devemos ser abençoados pelas gerações futuras como salvadores da humanidade, ou devemos ser amaldiçoados como o homem que fez "il gran rifuto"'.

79 CASELLA, Paulo Borba. Pax perpetua - a Review of the Cconcept from the Perspective of Economic Integration. In: CASELLA, Paulo Borba (Coord.). Dimensão Internacional do Direito - Estudos em homenagem a G. E. do Nascimento e Silva. São Paulo: LTr, 2000, p. 80, tradução livre do original: "the test of effective implementation although relevant [..], should not be too inflexibly applied to philosophical concepts attempting to turn state management practice. [...] Nevertheless we are not - and hopefully should not - drop the standard, although political practice runs unaware, considerably below the desirable standard". 


\section{UTILIDADE DO PROJETO À PAZ PERPÉTUA COMO ELEMENTO PARA DESCREVER O DESARMAMENTO NUCLEAR}

Como foi possível concluir no capítulo anterior, as bases em que se sustenta o tratamento internacional das armas nucleares são muito frágeis no sentido de garantir a convivência pacífica e harmoniosa entre os Estados.

Faz-se necessário, então, pensar em meios de se contrapor a essa realidade, caso se pretenda compreender o Direito Internacional como um meio de modelar a realidade social. Amaral Júnior descreve bem essa função do Direito Internacional que classifica como contemporâneo para lidar com "uma época de conflito generalizado". Para essa finalidade, o autor enxerga nele "um veículo para a busca do universal, suplantando realidade marcada por individualismos exacerbados", referindo-se à concepção da "razão pura kantiana como sua forma de manifestação mais elevada" ${ }^{1}$. Nesse sentido, atribui ao direito internacional contemporâneo a pretensão de

\footnotetext{
modelar a realidade social. Ele abandona o caráter exclusivamente formal que possuía, para converter-se em direito de regulamentação, que define o comportamento dos Estados com vistas à satisfação dos interesses gerais da comunidade internacional em seu conjunto.
}

Entretanto, ainda que se busque no direito internacional esse papel, a problemática em torno do desarmamento nuclear assume contornos bastante complexos porque, como foi observado, o poderio militar, sendo as armas atômicas sua representação mais efetiva, constitui um dos principais, senão o principal, esteios das políticas de afirmação dos Estados, representando papel essencial na política internacional. Daí a enorme relutância dos Estados nuclearmente armados em abdicarem do poderio que lhes atribui a posse de arsenais atômicos, mesmo que frustrando anseios cada vez mais difundidos internacionalmente em torno do banimento daquele tipo de armamento.

AMARAL JÚNIOR, Alberto do. O direito de assistência humanitária. São Paulo: Renovar, 2003, p. 3637. 
Trata-se, contudo, de elemento que, longe de atribuir estabilidade e segurança aos Estados, acaba fomentando o oposto, devido ao dilema da segurança. Em interessante trabalho sobre segurança internacional, há a seguinte descrição desse dilema:

os esforços unilaterais de um Estado para garantir sua própria segurança nacional são interpretados como elevação do nível de ameaça pelos demais Estados, levando estes à adoção de medidas defensivas (concorrentes aos esforços do primeiro Estado) para a sua própria segurança-promove insegurança ${ }^{2}$.

Apesar desse efeito paradoxalmente contrário ao objetivo inicial, ainda assim o militarismo permaneceu como elemento central nas políticas de segurança, especialmente devido à influência da Escola de Estudos Estratégicos, notadamente marcada por pensadores realistas que "reduziam o conceito de segurança ao conceito de poder, quase que exclusivamente militar" 3 .

As profundas influências dessa escola de pensamento podem ser consideradas como uma das principais razões para as fortes críticas que surgem contra proposições sobre a institucionalização de mecanismos pacíficos e desarmamento. Os argumentos nesse sentido repetidamente abordam como inconcebível a renúncia voluntária dos meios de se fazer a guerra ${ }^{4}$.

No tocante às armas nucleares, essa faceta negativista é igualmente verificada em diversos autores que abordam os obstáculos para seu banimento:

Para ser crível a proibição das armas nucleares, ela deveria ser precedida por uma destruição sincronizada de todas elas em todos os Estados nuclearmente armados. Atualmente é difícil conceber isso. [...] Mesmo se os países destruíssem todas suas armas, eles ainda manteriam a

2 RAMINA, Larissa; CUNHA FILHO, Valter Fernandes da. Segurança Internacional. Curitiba: Juruá, 2013, p. 26.

Ibidem., p. 31.

4 CASELlA, Paulo Borba. Pax perpetua - a review of the concept from the perspective of economic integration. In: CASELLA, Paulo Borba (Coord.). Dimensão Internacional do Direito - Estudos em homenagem a G. E. do Nascimento e Silva. São Paulo: LTr, 2000, p. 85. 
capacidade a tecnologia de produzir armas novamente. [...] o terror nuclear sempre estará conoscos.

De fato, o único meio de rivalizar contra essa constatação é por uma quebra de paradigma.

Num primeiro momento, uma abordagem que poderia contribuir para a mudança desse cenário seria não mais considerar a questão bélica como a principal premissa em torno da qual se funda a segurança internacional. Uma possível saída para suplantar o dilema da segurança, no lugar de desencorajar o inimigo por intermédio do desenvolvimento de tecnologia bélica e construção de armas, seria uma ação no sentido oposto. A proposição de "medidas de controle de armas e desarmamento seria uma forma de sinalizar ao inimigo sua disposição para a paz [...] [meio de] construção de um clima de confiança" 6 .

É fato que apenas essa proposição não seria suficiente para efetuar mudanças significativas na questão do desarmamento, sendo lúcida a percepção de Bull de que para sua realização "precisaríamos repensar toda a base das relações entre os estados" 7 . Até hoje em dia, a marca mais frequente dessa base é o realismo, que se reflete na definição de uma agenda política internacional apoiada, quase que exclusivamente, nas políticas de poder.

Como foi descrito por Soraya Nour, com apoio em Morgenthau ${ }^{8}$, o realismo avalia a prudência (aqui compreendida como a medição das consequências de ações políticas) como a suprema virtude da política. A autora diferencia, então, o que seria a ética política da ética em abstrato, que avalia as ações de acordo com a lei moral. Assim, seria necessária

5 LOUKA, Ellie. Nuclear Weapons, justice and the law. Cheltenham: Edward Elgar, 2011, p. 344-345, tradução livre do original: "For the prohibition of nuclear weapons to be credible, it should be preceded by the synchronized destruction of such weapons in all NWS. This is today difficult to fathom. [...] even if countries destroyed all their nuclear weapons, they would still maintain the capability and know-how to produce nuclear weapons again. [...] nuclear terror will always be with us".

6 RAMINA, Larissa; CUNHA FILHO, Valter Fernandes da. Segurança Internacional. Curitiba: Juruá, 2013, p. 48.

7 BULL, Hedley. A sociedade anárquica. Tradução de Sérgio Bath. São Paulo: Universidade de Brasília, 2002, p. 264.

8 MORGENTHAU, Hans J. Politics Among Nations. The struggle for power and Peace (1. ed. 1948). 5th ed. New York: Knopf, 1973, p. 10-11. apud NOUR, Soraya. À Paz Perpétua de Kant-filosofia do direito internacional e das relações internacionais. São Paulo: Martins Fontes, 2013, p. 118. 
uma gradativa transposição da ética política para a ética abstrata como fundamento principal da prática internacional.

A enorme dificuldade de se obter essa transposição já denota o caráter fortemente idealista da consolidação de uma prática internacional que avalie as ações de acordo com a lei moral no que toca ao desarmamento nuclear. É difícil, se não impossível, conceber um abandono do pragmatismo dos Estados possuidores de tais armamentos para, com base na lei moral, abdicarem deles - circunstância que impede vislumbrarmos essa evolução mesmo em longo prazo.

Pois é exatamente neste particular que se torna útil descrever a problemática do desarmamento nuclear à luz do projeto À Paz Perpétua. Como foi reconhecido por Kant no ensaio de 1795, a avaliação da realidade presente permite constatar diversas falhas e desvios contrários à moral. Tais falhas frustram as máximas de uma paz universal duradoura. Justamente para enfrentar com franqueza esses problemas é que se insere o viés utópico do projeto kantiano como baliza reguladora. Assim, ele determina que o comportamento seja avaliado na medida em que se aproxima ou se afasta de uma lei moral que, se observada, propiciará elementos para a construção da realidade pacífica idealizada.

Numa mesma medida, qualquer análise superficial do estado atual do desarmamento nuclear permite verificar suas imperfeições e inadequações ${ }^{9}$. Tamanhos são os problemas que, não raro, essas falhas são consideradas como obstáculos intransponíveis para a concretização de um desarmamento nuclear mundial completo ${ }^{10}$.

Depreende-se daí o viés utópico das propostas relativas ao desarmamento nuclear. Da mesma forma como a utopia é essencial na construção rumo À Paz Perpétua, como elemento regulador, isso também ocorre no que toca ao desarmamento nuclear.

Com efeito, ao se verificarem as fragilidades e inadequações que até hoje impediram sua consecução, mesmo que sejam de difícil superação, as proposições tidas por utópicas

9 Este tema será objeto de análise específica na segunda parte deste trabalho.

10 MORE, Rodrigo Fernandes. O Desarmamento no sistema de segurança coletiva da ONU. 2005.Tese (Doutorado) - Faculdade de Direito, Universidade de São Paulo, São Paulo, 2002, p. 280: "No Capítulo III desta tese consideramos a situação do Estado desarmado e, na análise do Artigo VI do TNP (1968), concluímos que, embora os esforços de desarmamento devam caminhar para a eliminação geral e completa, em especial das ADM (numa perspectiva kantiana), o desarmamento não deixará de ocorrer pela falta de confiança, mais apropriado seria dizer que não ocorrerá pela desconfiança recíproca entre Ocidente e não-Ocidente, como se verifica muito claramente na Conferência sobre Desarmamento". 
apontam qual o rumo a ser tomado, tornando-se, portanto, elemento de extrema utilidade para a superação gradativa desses obstáculos. Isso porque

a utopia não precisa ser a negação da realidade: pode ser o anseio, mais ou menos ordenado, ou desesperado, pelo aperfeiçoamento desta. [...] A expectativa de alcançar nova configuração do sistema internacional pode ser utópica, até poder alcançar, em maior ou menor grau, certo patamar de implementação na realidade. A partir daí terá deixado de ser utópica e passa a ser denominada, quiçá, visionária, idealista, ou avançada, para seu tempo e meio ${ }^{11}$.

Entretanto, é indispensável que se avalie essa realidade utópica em cotejo com elementos do presente, meio de evitar que as ideias propostas atinjam tamanho grau de abstração que as tornem completamente inúteis. Para isso, segundo a análise de Arendt sobre a concepção utópica no projeto do filósofo alemão, é importantíssimo notar que Kant situava seu pensamento utópico de acordo com o dever moral, mas evitando ignorar os dados da experiência concreta. Por isso, colocava-se num plano intermediário, acima da omissão criminosa diante das imperfeições da realidade, mas aquém da vagueza precária de um tolo idealista ${ }^{12}$.

Neste particular torna-se pertinente lembrarmos a ponderação de Wight sobre o realismo não possuir um caráter necessariamente negativo - "tudo depende se significa o abandono de ideais elevados ou de expectativas tolas" ${ }^{13}$.

Para identificar qual categoria aplica-se melhor ao desarmamento nuclear, ideal elevado ou expectativa tola, recorremos ao enfrentamento corajoso de Ramesh Thakur, exVice-Reitor da Universidade da ONU, ao refutar as críticas realistas contra as medidas necessárias para a existência de um mundo livre de armas nucleares:

Tais medidas tipicamente provocam comentários banalizantes dos assim chamados "realistas". Realisticamente falando, há alguma opção além daquelas identificadas aqui? Caso não haja, então qual é a opção mais

${ }^{11}$ CASELLA, Paulo Borba. Pax perpetua - a review of the concept from the perspective of economic integration. In: CASELLA, Paulo Borba (Coord.). Dimensão Internacional do Direito - Estudos em homenagem a G. E. do Nascimento e Silva. São Paulo: LTr, 2000, p. 345-349.

${ }^{12}$ ARENDT, Hannah. Lições sobre a filosofia política de Kant. Tradução de André Duarte de Macedo. Rio de Janeiro: Relume-Dumará, 1993, p. 70.

${ }^{13}$ WIGHT, Martin. A política do poder. Tradução de C. S. Duarte. Brasília: Editora Universidade de Brasília, 1985 , p. 239. 
preferível? Como o famoso aforismo de Winston Churchill sobre democracia, a opção abolicionista pode ser irrealista; todas as outras opções concebíveis são ainda menos realistas enquanto estratégias de segurança e sobrevivência. ${ }^{14}$

Nesse sentido, como sua posse e uso não representam alternativas realisticamente adequadas enquanto estratégia de sobrevivência, as armas nucleares acabam fomentando, reversamente, iniciativas em prol de sua contenção e do próprio desarmamento nuclear. Lafer descreve esse processo ao reconhecer que

a ameaça latente que as armas nucleares representam para a sobrevivência da humanidade, ao ir fomentando uma consciência dos riscos da guerra atômica, deu nova dimensão ao discurso do pacifismo. Com efeito, esta ameaça, ao questionar e problematizar a sabedoria convencional sobre a inevitabilidade da guerra no processo histórico, vem estimulando a necessidade de a razão prática buscar, kantianamente, os caminhos da paz perpétua ${ }^{15}$.

É importante notar a identificação do papel da utopia como fator indispensável para a mudança, necessária tanto para que se vislumbrem cenários alternativos, quanto para a aferição valorativa de políticas concretas ${ }^{16}$.

Esse é o posicionamento que Kant entende como necessário em relação aos exemplos da realidade, tomando-os como lição do que deve ser superado, já que "a História mata e as relações internacionais brilham por sua des-razão" ${ }^{17}$.

Contra essas demonstrações de uma realidade ainda imperfeita e não condizente com a lei moral, Kant estabelece que se deva agir de acordo com esta última, para que seja possível superar essas imperfeições. Com isso, propiciar-se-ia a construção contínua do

14 THAKUR, Ramesh. North Korea \& alternative nuclear futures in War in our time - reflections on Iraq, terrorismo and weapons of mass destruction. Tokyo: United Nations University, 2007, p. 191, tradução do original: "Such scenarios typically provoque dismissive comments from so-called 'realists'. Realistically speaking, is there another option beyond those identified here? If not, then which is the most preferred option? As with Winston Churchill's famous aphorism on democracy, the abolitionist option may well be unrealistic; all other conceivable options are even less realistic as strategies of security and survival".

15 LAFER, Celso. Paradoxos e possibilidades. Rio de Janeiro: Nova Fronteira, 1982, p. 85.

16 Ibidem, p. 90.

17 MELLO, S. V. de. História Filosófica e História Real: Atualidade do Pensamento Político de Kant. In: MARCOVITCH, J. (Org.). Sérgio Vieira de Mello - pensamento e obra. São Paulo: Editora Universidade de São Paulo e Saraiva, 2004, p.. 40. 
direito internacional, por ele denominado "direito das gentes", numa escala evolutiva rumo a um direito cosmopolítico, etapa em que seria possível considerar viável uma paz perene.

Trata-se de uma construção pautada pela tensão entre razão e instinto, sendo que, segundo Kant, o fio condutor da história da humanidade apenas possuiria algum sentido se esta fosse compreendida sob um ângulo de evolução racional universal.

Verificam-se, portanto, as contribuições de se utilizar o projeto À Paz Perpétua como elemento de referência para o desarmamento nuclear. Ambos o estado propício à guerra e a situação nuclear atuais têm de ser assumidos como elementos imperfeitos, que demandam uma construção gradativa por meio da adoção e reforço de comportamentos e normas de conduta cada vez mais próximos do ideal moral.

Novamente nos valemos de Vieira de Mello para ilustrar como Kant propõe a dinâmica da evolução da humanidade:

Ao salientar a distância que separa o progresso institucional do progresso ético, o progresso jurídico do moral, Kant põe em evidência uma esquizofrenia da História, com a qual a humanidade deve aprender a conviver e que ela deve, progressivamente, conseguir dominar. ${ }^{18}$

Verifica-se aí a percepção da finalidade evolutiva, decorrente de uma ideia balizadora do comportamento e da compreensão histórica alinhada a ela. Essa orientação pautada por um ideal moralizante deve orientar a experiência, em vez de o ser humano se resignar a ela e permitir que acabe invalidando o atingimento dos ideais. Trata-se de agir em conformidade com a realidade imaginada, aproximando-a, mesmo que a passos curtos, cada vez mais da realidade presente.

São plenamente válidas as críticas contra as graves inadequações e distorções do regime de não proliferação nuclear, e das frustrações históricas em relação ao banimento das armas atômicas. Essa percepção, contudo, não pode invalidar a necessidade de se lutar pela superação dessas falhas.

18 MELlo, S. V. de. História Filosófica e História Real: Atualidade do Pensamento Político de Kant. In: MARCOVITCH, J. (Org.). Sérgio Vieira de Mello - pensamento e obra. São Paulo: Editora Universidade de São Paulo e Saraiva, 2004, p. 55. 
O desarmamento nuclear completo, nos dias de hoje, aparenta idealismo vago e tolo. Contudo, basta breve reflexão para identificar exemplos históricos extremamente relevantes de questões cuja superação era considerada igualmente utópica. Seu enfrentamento crítico, racional, propiciou amadurecimento e, mesmo isto tendo demorado longo tempo para acontecer, elas foram ultrapassadas e banidas, em verdadeiras conquistas da evolução histórica pautada pela razão.

Não é de se estranhar, por exemplo, a equiparação do ideal do desarmamento nuclear à luta pela abolição da escravatura, que marcou especialmente os séculos XVIII e XIX. Segundo Freeman Dyson, Professor de Ciências Políticas na Universidade Estadual da Pensilvânia, especialista em temas relativos à segurança nacional, defesa estratégica, controle de armas nucleares, dentre outros:

\begin{abstract}
A abolição das armas nucleares é uma tarefa de magnitude similar à abolição da escravidão. Armas nucleares são, atualmente, como a escravidão era duzentos anos atrás, um manifesto mal institucional profundamente arraigado nas estruturas sociais. Aqueles que almejam pressionar a luta contra armas nucleares num rumo exitoso devem reunir as mesmas qualidades que prevaleceram na luta contra a escravatura: convicção moral, paciência, objetividade e disposição para fazer concessões ${ }^{19}$.
\end{abstract}

Aqueles que se posicionavam contrariamente ao movimento abolicionista da escravatura, dentre outros argumentos pautados apenas por interesses financeiros, enxergavam uma verdadeira impossibilidade de serem alteradas as bases em que se estruturava um sistema produtivo consolidado há séculos. Lutar contra elas seria tão distante da realidade que apenas se compreendia como algo utópico. Isso sem levar em conta demais apelos ideológicos e pseudocientíficos sobre divisão e hierarquia de raças humanas.

19 FREEMAN, Dyson. Weapons and hope. New York: Henry Holt and Company, 2007, 1985, p. 201, apud CIMBALA, Stephen J. Nuclear Weapons and Cooperative Security in the $21^{\text {st }}$ Century. New York: Routledge, 2010 , p. 25 , tradução do original: "The abolition of nuclear weapons is a task of the same magnitude as the abolition of slavery. Nuclear weapons are now, as slavery was two hundred years ago, a manifestly evil institution deeply embedded in the structure of our society. People who hope to push the fight against nuclear weapons to a successful conclusion must bring to their task the same qualities which won the fight against slavery: moral conviction, patience, objectivity, and willingness to compromise". 
Foram anos de luta e muitos percalços. Contudo, caso as dificuldades determinassem o abandono da luta por essa mudança na base axiomática que justificava e legitimava a escravidão, o próprio pensamento contra ela seria impedido. Haveria uma consolidação de uma realidade precária, imperfeita, em que eram aceitos abusos inimagináveis contra os povos escravizados, o congelamento de um contexto que, necessariamente, contrariava a concepção da evolução racional da história.

Hoje em dia, escravidão é circunstância vedada internacionalmente como gravíssima e inaceitável agressão contra os direitos humanos, sendo tema constante inclusive da Declaração Universal de $1948^{20}$.

Nesse breve exemplo fica evidente a relevância do pensamento kantiano para lidar com temas como o desarmamento nuclear.

Segundo o próprio Kant, a recusa das proposições por mudanças tão difíceis e complexas, mas tão importantes, seria a postura do prático, que fundamenta sua conformação "na sua pretensão de que ele pretende ver antecipadamente a partir da natureza do homem que ele nunca irá querer aquilo que seja necessário para atingir a paz perpétua" 21.

Essa recusa do prático ignora a necessidade de se pretender construir as mudanças para que se atinja a paz perpétua. Uma dessas mudanças, como já foi observado, se daria por meio do pacifismo estrutural, ou seja, o desarmamento, aqui focado especificamente em sua vertente nuclear. O pensador alemão, contudo, já reconhecia os obstáculos que a disputa pelo poder representava para essas mudanças:

Um Estado que não está na situação de não estar sob nenhuma lei exterior não se fará, com respeito ao modo como ele deve procurar seu direito contra outros Estados, dependente do foro deles, e mesmo uma parte do mundo, quando se sente superior a uma outra, que, aliás, não está em seu caminho, não deixará inutilizado o meio de fortalecimento de sua potência $^{22}$.

20 UNIDOS PELOS DIREITOS HUMANOS. Disponível em: http://www.humanrights.com/pt/what-arehuman-rights/universal-declaration-of-human-rights/articles-01-10.html. Acesso em: 18 dez. 2014.

21 KANT, I. À Paz Perpétua. Tradução de M. A. Zingano. São Paulo: L\&PM Editores, 1989, p. 60-61.

22 Ibidem, p. 61. 
Uma das maneiras de se modificarem as bases do pensamento sobre o desarmamento nuclear seria, então, a adoção de retórica refletida em políticas públicas que tivessem por meta deslegitimar esse tipo de armamento. Gradativamente, essa deslegitimação acabaria gerando constrangimento cada vez maior contra os Estados, pressionando-os a abandonar sua insistência histórica na manutenção de políticas internacionais lastreadas nesse tipo de armamento. A meta é transformar as armas nucleares em fatores impensáveis, como a escravidão e o genocídio são compreendidos atualmente:

\begin{abstract}
A ideia das armas nucleares deve primeiramente se tornar materialmente impensável como o genocídio se tornou no presente século. É claro, o genocídio ainda ocorre, no plano interno e internacional. Mas quem os comete assume posição deslocada da legitimidade atribuída por normas legais e políticas, especialmente em face da massiva desaprovação da opinião pública e da mídia. As armas nucleares ainda estão bem longe de possuírem essa aura negativa 23 .
\end{abstract}

A relevância dessa proposta é enorme, já que permite um primeiro passo para romper com as justificativas que aceitam e tentam legitimar as armas nucleares e o terror do equilíbrio da dissuasão como um fator perene das relações internacionais.

A partir dessa "condenação" da opinião pública, torna-se muito mais fácil a aprovação de normas que permitam viabilizar, ou tornar mais próximo da realidade, o banimento das armas nucleares. As normas teriam, nesse contexto, um papel essencial, porque o discurso deslegitimador poderia se tornar um meio adicional de reforço de sua eficácia. Não se pode subestimar a relevância da opinião pública no que toca à política internacional.

Habermas, por exemplo, ao debater em que medida seria possível verificar atualmente como se daria a proposição de Kant sobre o peso que as manifestações públicas dos filósofos teria para influenciar a política pública dos Estados, reconhece a elevada significância de uma esfera pública global. Segundo o autor, apesar dos aspectos negativos

23 CIMBALA, Stephen J. Nuclear Weapons and Cooperative Security in the $21^{\text {st }}$ Century. New York: Routledge, 2010 , p. 30, tradução do original: "the idea of nuclear weapons must first become as substantively 'unthinkable' as genocide has become in the present century. Of course, genocides still occur, within and among states. But they take place outside the legitimacy of international legal and political norms, and in the face of widespread public and media disapproval. Nuclear weapons are a long way from this aura". 
decorrentes da comunicação de massa global, como o uso massificado da mídia aparelhada por interesses específicos, essa esfera pública analisa em tempo real conflitos deflagrados mundo afora, exercendo papel fiscalizador que influencia de modo determinante a prática internacional, inclusive por meio de organizações não governamentais de escala planetária como Greenpeace e Human Rights Watch ${ }^{24}$.

Assim, o respeito a essas normas, mesmo que num primeiro momento de modo coercitivo, não voluntário, acabaria amoldando a realidade num processo de retroalimentação pelo efeito de inspiração educadora daí obtido.

Para obter o estado de paz, ou o estágio mais avançado da história pautada pela razão, os homens deveriam acabar reconhecendo o conceito de um direito público efetivo e se submetendo a ele, mesmo com inúmeras justificativas para continuar atribuindo à força e ao poder a prevalência sobre aquele. Diferentemente do moralista político, que subordina os princípios ao fim, Kant cita sua máxima: "age de tal forma que tu possas querer que tua máxima deva tornar-se uma lei universal."25

Trata-se da “"sobrefunção” educadora da utopia, a qual questiona a si própria e procede a reavaliações constantes, dos fins táticos e últimos que ela propõe à História, a cujos desdobramentos procura precisamente se adequar" 26 .

A conduta de acordo com a norma moral, o ideal a ser respeitado, mesmo que, num estágio inicial, de maneira simulada, não genuína, acabaria reforçando as próprias bases de aplicação e respeito das normas morais. Seria uma espécie de tintura moral, que facilita a afirmação do direito porque representa um grande passo para a moralidade, ainda que não seja, ela própria, um passo moral.

24 HABERMAS, J. Kant's Idea of Perpetual Peace: At Two Hundred Years'Historical Remove. In: The inclusion of the other - studies in political theory. Cambridge: MIT Press, 1998, p. 177. O papel da opinião pública, inclusive na acepção de sanção contrária a determinados atos, é tema recorrente. Cf. BULL, Hedley. A sociedade anárquica. Tradução de Sérgio Bath. São Paulo: Universidade de Brasília, 2002, p. 56; SOARES, Guido Fernando Silva. Legitimidade de uma guerra preventiva? In: DUPAS, Gilberto; LAFER, Celso; SILVA, Carlos Eduardo Lins da (Org.). A nova configuração mundial do poder. São Paulo: Paz e Terra, 2008, p. 245; KOSKENNIEMI, Marti. The gentle civilizer of nations - the rise and fall of International Law. Cambridge: Cambridge University, 2001, p. 15; e WALTZ, Kenneth N. $O$ homem, o estado e a guerra. São Paulo: Martins Fontes, 2004, p. 127.

25 KANT, I.À Paz Perpétua. Tradução de M. A. Zingano. São Paulo: L\&PM Editores, 1989, p. 68.

26 MELLO, S. V. de. História Filosófica e História Real: Atualidade do Pensamento Político de Kant. In: MARCOVITCH, J. (Org.). Sérgio Vieira de Mello - pensamento e obra. São Paulo: Editora Universidade de São Paulo e Saraiva, 2004, p. 43-44. 
Guardando-se as proporções, é muito interessante a maneira como Sponville recorre à proposta kantiana para fundamentar justamente o papel normatizador e educador que a moral possui, num primeiro momento, ao ser imposta, para que, depois, seja possível afirmar a existência de uma moralidade:

Kant nos esclarece melhor, ao explicar esses primeiros simulacros da virtude pela disciplina, isto é, por uma coerção externa: o que a criança, por falta de instinto, não pode fazer por si mesma, é preciso que outros façam por ela, e é assim que uma geração educa a outra. [...] Disciplina normativa mais do que coerciva, que visa menos à ordem do que a certa sociabilidade amável. É por ela que, imitando as maneiras da virtude, talvez tenhamos uma oportunidade de vir a ser virtuosos. [...] Dizer "por favor" ou " "desculpe" é simular respeito; dizer "obrigado" é simular reconhecimento. É aí que começam o respeito e o reconhecimento. [...] Portanto, a polidez salva a moral do círculo vicioso (sem a polidez, seria necessário ser virtuoso para poder tornar-se virtuoso) criando as condições necessárias para seu surgimento e, mesmo em parte, para seu pleno desenvolvimento. ${ }^{27}$

"Imitando as maneiras da virtude, talvez tenhamos uma oportunidade de vir a ser virtuosos". A conduta moral, nesse exato sentido, num primeiro momento imposta até coercivamente, exerceria um efeito dinâmico, normativo e educador.

Os Estados, aplicando-se essa leitura nas relações internacionais e nas políticas de segurança, ao se beneficiarem do espraiamento cada vez maior da conduta moral pelos demais membros da sociedade em que convivem, identificarão vantagens e seus próprios comportamentos não mais serão reflexo de obediência coagida, mas uma busca da consolidação e aprimoramento da realidade que lhes apraz.

Essa consolidação do comportamento moral seria decisiva, afastando cálculos individualistas ou oportunistas dos Estados em relação ao uso, ou à mera ameaça de uso, das armas nucleares. Numa segunda etapa, mesmo sua proscrição e banimento seriam metas mais factíveis.

Mesmo sob o risco de sofrer derrotas em conflitos, não haveria risco de um conflito nuclear porque

27 SPONVILle, A. C. Pequeno Tratado das Grandes Virtudes. Tradução de E. Brandão. São Paulo: Martins Fontes, 1995, p. 17-18. 
se o que fazemos para evitar a catástrofe viola as normas morais, [isso] é, por definição, injusto, por melhores que possam ser as consequências de fazermos isto. Uma exceção a uma norma moral, portanto, nunca é, rigorosamente falando, "justificada", a menos que derive de outra norma moral. "Justiça" e "justificação" dizem respeito a normas, não a fins ${ }^{28}$.

Nesse cenário imaginado, mesmo em situações de crise, ou especialmente durante estas, seria prevenido o risco de que os Estados viessem

a agir irracionalmente, permitindo que seu raciocínio fosse guiado por normas morais e, assim, a probabilidade de que em tais situações confundissem regularmente as consequências desagradáveis de agirem moralmente com catástrofe, derrota com aniquilamento, a vitória de seus inimigos como o triunfo do mal ${ }^{29}$.

Essa observação é muito relevante porque as potências nucleares perigosamente flertam com o uso ou ameaça de uso de armas atômicas mesmo diante de derrotas e frustrações que nunca poderiam legitimar ataque tão terrível.

O maniqueísmo na avaliação das políticas externas acaba sendo permissivo com a consideração de que toda derrota militar ou política, mesmo não central para estratégias de defesa, é considerada inaceitável, justificativa para o cometimento de qualquer barbaridade ${ }^{30}$.

Importante, neste momento, para não seguir numa divagação que, como ressalvado mais acima, transformaria a discussão num idealismo tolo, é refrear as ilações e voltar as atenções à dificuldade prática da concretização da moral como balizadora na questão nuclear.

Como já se identificou no capítulo anterior, essa dificuldade decorre justamente de como se encontra embrenhado nas bases da ordem internacional atual o elemento das armas nucleares como sustentáculo principal das estratégias de defesa e poder.

28 NARDIN, Terry. Lei, moralidade e as relações entre os Estados. Rio de Janeiro: Forense, 1987, p. 296.

29 Ibidem, p. 299.

30 LOUKA, Ellie. Nuclear Weapons, justice and the law. Cheltenham: Edward Elgar, 2011, p. 8-9, tradução livre do original: "muitos Estados condenam o uso de armas químicas, mas permanece claro qual seria sua conduta diante do calor de uma crise militar". 
A referência à "ordem internacional”, aqui, faz-se no sentido atribuído por Bull, ou seja, "um padrão de atividade que sustenta os objetivos elementares ou primários da sociedade dos estados, ou sociedade internacional". 31 Segundo o autor, essa ordem internacional ainda é dominada por objetivos como "a manutenção da independência ou soberania externa dos estados individuais, manutenção da paz como ausência de guerra, meta subordinada à preservação do sistema de estados" 32 .

No que tange à questão nuclear, essa ordem internacional não aparenta propensão alguma a uma mudança no sentido de um banimento das armas atômicas. Interessante, nesse sentido, notar, na sequência, como Bull estabelece que essa ordem internacional não atende aos anseios do que constituiria a ordem mundial, que seria formada pelos seres humanos individuais, e que esta última é que deveria prevalecer sobre a primeira:

\begin{abstract}
A ordem mundial é mais fundamental e primordial do que a ordem internacional porque as unidades primárias da grande sociedade formada pelo conjunto da humanidade não são os estados (como não são as nações, tribos, impérios, classes ou partidos), mas os seres humanos individuais - elemento permanente e indestrutível, diferentemente dos agrupamentos de qualquer tipo. Hoje são as relações internacionais que estão em foco, mas a questão da ordem mundial surge qualquer que seja a estrutura política ou social do mundo. [...] a ordem mundial precede moralmente a ordem internacional [...]. Se a ordem internacional tem algum valor, isto só pode ocorrer porque ela é um instrumento orientado para atingir a meta maior, da ordem no conjunto da sociedade humana. ${ }^{33}$
\end{abstract}

Verifica-se, pois, qual o tamanho do paradigma a ser rompido para que, por exemplo, as armas nucleares sejam finalmente proscritas e ocorra um retorno do mundo a uma realidade livre de sua ameaça. Parece-nos claro que sua manutenção é mais condizente com as necessidades de manutenção da ordem internacional descrita por Bull, do que com aquelas compatíveis com a ordem mundial. O desafio é gigantesco, e, aparentemente, inviável de ser enfrentado na prática.

Contudo, se ao invés de se ter em mira a grande subversão de valores necessária para a transposição da preponderância da ordem internacional para a ordem mundial, forem

\footnotetext{
${ }^{31}$ BULL, Hedley. A sociedade anárquica. Tradução de Sérgio Bath. São Paulo: Universidade de Brasília, 2002, p. 13.

${ }^{32}$ Ibidem, p. 23-25.

${ }^{33}$ Ibidem, p. 29.
} 
estabelecidos objetivos modestos que propiciem uma construção lenta e gradual, o objetivo poderá ser atacado. Do mesmo modo, estará sendo verificado o comportamento proposto por Kant em seu ensaio À Paz Perpétua.

Nesse exato sentido, é novamente pertinente retomar as palavras de Casella ${ }^{34}$, quando contextualiza a análise das relações internacionais e sua sujeição crescente ao direito. Apesar das inúmeras guerras, o autor identifica no século $\mathrm{XX}$ a relevante conquista do estabelecimento de instituições internacionais que viabilizam e catalisam a cooperação dos homens, permitindo a superação dos jogos de poder maquiavélicos.

Essas conquistas apenas são viáveis quando se tem no Direito Internacional um elemento muito mais influente do que apenas sua mera 'faceta notarial' de reproduzir por escrito aquilo já verificado nas relações de poder ${ }^{35}$.

Nessa dimensão, o direito internacional é reforçado em seu caráter normatizador e modelador da realidade, alinhando-se ao ideal de evolução racional da humanidade. Ainda que "o homem saiba que nunca alcançará a perfeição", estará respeitando "sua grandeza, ligada à renovação da tentativa por meio da qual poderá encontrar sua verdadeira dimensão de humanidade" ${ }^{36}$. Ou, como já havia sido afirmado por Kelsen, trata-se de respeitar o direito internacional como uma ordem para promover a paz ${ }^{37}$. Assim, a finalidade do direito internacional seria definir uma realidade jurídica que representasse um avanço em relação ao sistema atual, reformando-se as relações internacionais. Segundo o autor, o destino da civilização dependeria do êxito dessa reforma ${ }^{38}$.

É interessante notar que não se está aqui novamente rebaixando o direito a um papel quixotesco e vazio de utilidade prática. Diferentemente, é possível constatar que o Direito Internacional, nesse contexto, assume relevante papel de instrumento de construção de um mundo livre de armas nucleares, que hoje ainda se tem como utópica. Trata-se, como já se viu, de considerar as lutas por avanços, mesmo pequenos, pautados pelo viés da utopia como meio e referência para o aperfeiçoamento da realidade.

34 CASELLA, Paulo Borba. Fundamentos do direito internacional pós-moderno. São Paulo: Quartier Latin, 2008, p. 903.

35 Ibidem, p. 321-322.

36 CASELLA, Paulo Borba. Direito Internacional, Terrorismo e Aviação Civil. São Paulo: Quartier Latin, 2006, p. 17.

37 KELSEN, Hans. Derecho y las relaciones internacionales. Tradução de Florencio Acosta. 2. ed. Cidade do México: Fondo de Cultura Económica, 1986, p. 23.

38 Ibidem, p. 23-24. 
Destacamos, a título de ilustração, o 'Discurso dos Três Ds', proferido em 19 de setembro de 1963 pelo então Chanceler João Augusto de Araújo Castro por ocasião da abertura da $18^{\text {a }}$ Assembleia-Geral das Nações Unidas, um dos mais conhecidos pronunciamentos da história da diplomacia brasileira:

Comparada com o Desarmamento, qualquer outra questão política, por mais difícil que nos pareça - e citemos como exemplo a de Berlim parece relativamente fácil de resolver-se, porque, em qualquer solução eventual, cada lado teria uma ideia aproximada do que estaria a ganhar ou a perder e também porque qualquer solução porventura alcançada poderia não ser final ou definitiva, se se conservassem os meios e a possibilidade de alterá-la. O Desarmamento é um problema de poder e, tradicionalmente, os problemas de poder se têm resolvido pela operação do próprio mecanismo do poder. O desafio de Genebra consiste precisamente em resolver este problema de poder através de negociações e por meio de persuasão. Não é tarefa fácil, e um senso elementar de realismo nos leva a admitir que ainda estamos muito longe da conclusão de um Tratado de Desarmamento Geral e Completo ${ }^{39}$.

Logo adiante, apesar desses obstáculos, o então chanceler brasileiro destaca uma primeira conquista internacional contra a realidade internacional dominada pelas armas nucleares, o Tratado de Moscou de $1963^{40}$, também chamado Tratado Parcial Contra Testes Nucleares.

Mesmo reconhecendo suas limitações, o diplomata brasileiro pôde constatar naquele tratado, além do "grande mérito de afastar imediatamente os efeitos nocivos das contaminações radioativas", seu importante "valor simbólico de demonstrar que sempre é possível e viável um esforço comum das grandes potências para comporem suas divergências" para, ao final, considerá-lo como um ponto de partida para entendimentos ainda mais amplos e criadores. ${ }^{41}$

39 BRASIL. Ministério das Relações Exteriores. Blog Diplomacia Pública. Desarmamento, desenvolvimento $e$ descolonização: 50 anos do "Discurso dos 3 Ds". 19 set. 2013. Disponível em: http://diplomaciapublica.itamaraty.gov.br/onu/41-o-discurso-dos-tres-ds. Acesso em: 5 dez. 2014.

${ }^{40}$ UNITED NATIONS. Treaty Banning Nuclear Weapon Tests in the Atmosphere, in Outer Space and under Water. Opened for signature at London (L), Moscow (M) and Washington (W): 8 Aug. 1963. Disponível em: http://www.un.org/disarmament/WMD/Nuclear/pdf/Partial_Ban_Treaty.pdf. Acesso em: 17 dez. 2014.

41 BRASIL. Ministério das Relações Exteriores. Blog Diplomacia Pública. Desarmamento, desenvolvimento $e$ descolonização: 50 anos do "Discurso dos 3 Ds". 19 set. 2013. Disponível em: http://diplomaciapublica.itamaraty.gov.br/onu/41-o-discurso-dos-tres-ds. Acesso em: 5 dez. 2014. 
Esta é exatamente a maneira pela qual se poderia pautar o desarmamento nuclear sob o prisma do ensaio À Paz Perpétua.

Há sérias lacunas e imperfeições no aparato institucional e normativo internacional existente para regular essa questão. Muitas dessas falhas, conforme será analisado na segunda parte deste trabalho, decorrem de fragilidades intencionalmente estabelecidas pelos próprios Estados: um meio de apoiarem um tema 'politicamente correto', sem se vincularem a obrigações que não pretendem observar na prática.

Ainda assim o estabelecimento de normas, mesmo falhas, como ficará evidente na análise do pilar central do regime de não proliferação nuclear, o TNP, de 1968, acaba representando conquistas que reforçam mecanismos que se somam e vão permitindo identificar uma edificação cada vez mais complexa e funcional de uma realidade que, um dia, permitirá considerar o desarmamento não mais como um elemento da utopia.

A próxima parte desta dissertação, ao trazer uma descrição crítica dos principais elementos normativos e institucionais internacionais relacionados ao desarmamento nuclear, será útil para ilustrar o quanto aqui se afirma. 
PARTE II

ANÁLISE CRÍTICA DOS ELEMENTOS QUE COMPÕEM O REGIME DE NÃO PROLIFERAÇÃO E DESARMAMENTO NUCLEAR 


\section{O INÍCIO DA ERA NUCLEAR}

A tarefa proposta, agora, é efetuar uma análise crítica dos principais elementos que constituem o aparato institucional e normativo existente atualmente, desenvolvido com a finalidade, ao menos propagada, de promover a luta pelo controle e banimento das armas nucleares.

Nessa descrição crítica, buscar-se-á identificar traços que permitam sua leitura em cotejo com a referência kantiana, isto é, enxergando-se que o desarmamento nuclear se configura na atualidade como uma realidade imperfeita cujas conquistas, mesmo pequenas ou contraditórias, devem ser compreendidas como passos concretos de desenvolvimento e construção em rumo dos objetivos maiores.

Como foi observado nos capítulos anteriores, a luta pelo controle e banimento das armas nucleares constitui um tema extremamente controvertido, sendo comumente reduzido à utopia sem validade prática. Ao lado dos aspectos geopolíticos, fatos anteriores ao primeiro uso das armas nucleares também podem ser considerados como fatores adicionais que acirram ainda mais essa característica polêmica.

Faz-se necessária, então, uma breve contextualização do momento histórico que motivou o desenvolvimento das primeiras armas nucleares, e dos primeiros esforços internacionais por seu controle e banimento.

É interessante notar, inicialmente, que muitos dos cientistas que se envolveram no desenvolvimento das armas atômicas, seja pela colaboração com estudos anteriores, incentivos e alertas às autoridades, ou propriamente pela participação no Projeto Manhattan, como ficou conhecido o programa norte-americano de desenvolvimento da energia nuclear para fins bélicos, não se tratavam de cegos defensores da guerra, nem tampouco praticavam a ciência de modo acrítico e amoral.

Vale destacar, nesse sentido, que são recorrentes os textos de Einstein em que se destaca o viés pacifista e humanista do cientista, e que o próprio coordenador principal do Projeto Manhattan, J. Robert Oppenheimer, acabou sofrendo duras consequências por ter se posicionado contrariamente à corrida armamentista que se iniciava, e por ter lutado contra o desenvolvimento das terríveis Bombas de Hidrogênio. 
Apesar do papel fundamental de Oppenheimer para o sucesso do Projeto Manhattan, sua luta contra o aprofundamento da corrida armamentista nuclear acabou levando-o a ser execrado pela opinião pública e as autoridades americanas, que passaram a considerá-lo um risco para a segurança nacional ${ }^{1}$.

Contudo, mesmo esses dois cientistas apoiaram o desenvolvimento dos estudos das armas nucleares porque o mundo vivia um momento de exceção pautado principalmente pelo temor ao eixo nazifascista.

Não por acaso, diversos dos cientistas que se envolveram na iniciativa americana eram refugiados europeus perseguidos pelo regime hitlerista. que conheciam os esforços alemães na busca do domínio do ciclo da energia nuclear para fins bélicos, e temiam as consequências de eventual êxito do Terceiro Reich nessa empreitada.

Por isso é que se pode afirmar que a guerra nuclear foi mais uma das trágicas consequências do nazifascismo. Segundo Hobsbawm, "uma simples guerra entre Estadosnações certamente não teria levado os físicos nucleares de ponta, eles próprios em grande parte refugiados ou exilados do fascismo, a exortar os governos britânico e americano a construir uma bomba nuclear" ${ }^{2}$. Sobre isso, vale citar o próprio Einstein:

\begin{abstract}
Minha responsabilidade na questão da bomba atômica se limita a uma única intervenção: escrevi uma carta ao presidente Roosevelt. Eu sabia ser necessária e urgente a organização de experiências de grande envergadura para o estudo e a realização da bomba atômica. Eu o disse. Conhecia também o risco universal causado pela descoberta da bomba. Mas os sábios alemães se encarniçavam sobre o mesmo problema e tinham todas as chances para resolvê-lo. Assumi, portanto, minhas responsabilidades. ${ }^{3}$
\end{abstract}

Essa, talvez, tenha sido uma das circunstâncias que favoreceram o desenvolvimento das armas atômicas, contra o qual se poderia aventar, num cenário distinto, uma posição de

1 KUZNICK, Peter J. A Tragic Life: Oppenheimer and the Bomb. Disponível em: <https://www.armscontrol.org/print/1851>. Acesso em: 21 Dez. 2014. Ver ainda ZUCKERMAN, Solly. Nuclear Illusion and Reality. New York: The Viking, 1982, p. 110.

2 HOBSBAWM, Eric. Era dos extremos. Tradução de Marcos Santarrita. 2. ed. São Paulo: Companhia das Letras, 1995, p. 527.

3 EINSTEIN, Albert. Como vejo o mundo. Tradução de H.P. Andrade. Rio de Janeiro: Nova Fronteira, 2011, p. 59. 
cientistas tão renomados, recusando-se a se envolver no aprimoramento da capacidade destrutiva da humanidade.

Não por acaso, confrontados com os terríveis efeitos que suas descobertas apresentaram, os cientistas manifestaram-se cada vez mais contrários ao seu uso, havendo registro de "desesperadas lutas de última hora para impedir os políticos e generais de usar de fato a bomba" ${ }^{4}$.

Abranches chega a mencionar que alguns dos envolvidos passaram a nutrir esperanças de que a guerra terminasse antes que fosse possível utilizar a nova arma ${ }^{5}$. Segundo o mesmo autor, a ideia da proscrição das armas nucleares surgiu antes mesmo do seu primeiro uso ${ }^{6}$.

É interessante a seguinte descrição das iniciativas desse movimento surgido, entre os cientistas engajados no desenvolvimento das armas atômicas, passando desde a recusa em colaborar com o projeto, até a esperança de não obterem sucesso, e incluindo a proposição de alternativas para que se evitassem as consequências de um ataque contra zonas habitadas:

\begin{abstract}
Os cientistas que haviam criado a nova arma eram muito menos entusiasmados do que as autoridades militares a respeito dos futuros resultados. Em realidade, numerosos cientistas se haviam recusado terminantemente a tomar parte no projeto. Outros o fizeram com a esperança de que suas investigações demonstrassem ser impraticável a bomba atômica. Quando a bomba se tornou realidade, um grupo de cientistas, que havia tomado parte nos trabalhos, redigiu um memorial solicitando que a bomba fosse empregada de modo a demonstrar o seu poder ser acarretar perdas de vida. Se ela fosse lançada numa zona desabitada do Japão, e se isso fosse ligado a uma versão mais clara da declaração de Potsdam, dificilmente poder-se-á saber quais teriam sido os resultados. ${ }^{7}$
\end{abstract}

Essa resistência ao seu uso não se restringiu aos cientistas, tendo sido verificada mesmo entre militares, conforme se depreende do pronunciamento do Gal. George

4 HOBSBAWM, Eric. Era dos extremos. Tradução de Marcos Santarrita. 2. ed. São Paulo: Companhia das Letras, 1995, p. 527.

5 ABRANCHES, C.A. Dunshee de. Proscrição das armas nucleares. São Paulo: Freitas Bastos, 1964, p. 37.

6 Ibidem, p. 114.

7 MCINNIS, Edgard. História da II Guerra Mundial - sexto e último ano de operações. Tradução de Homero de Castro Jobim. Porto Alegre: Globo, 1962, p. 244. 
Marshall e do Subsecretário da Marinha, Ralph A. Bard, pela necessidade de um aviso prévio ao Japão que pudesse evitar um ataque nuclear ${ }^{8}$.

De todas essas iniciativas, não se poderia ignorar o documento conhecido como Relatório Franck ${ }^{9}$, enviado ao Secretário da Guerra americano em 11 de junho de 1945, pelo Professor James Franck, que presidia a Comissão de Implicações Sociais e Políticas do emprego da energia nuclear para fins bélicos.

Naquele documento, era recomendado que se fizesse uma demonstração do novo armamento em uma ilha remota, na presença de representantes de todas as nações, para que testemunhassem com o que se deparariam caso a guerra continuasse.

Essa proposta era pautada por uma relevante ponderação de ordem ético-política, antevendo que caso a nova arma fosse utilizada, os EUA perderiam apoio da opinião pública e precipitariam uma corrida armamentista que inviabilizaria 'um futuro acordo internacional sobre o uso de tais armas'.

Como se sabe, o caráter visionário do Relatório Franck confirmou-se.

Apesar das tentativas contrárias, em 6 de agosto de 1945, às 8:15, foi efetuado o primeiro ataque nuclear da história, contra Hiroshima, sucedido pelo ataque de 9 de agosto de 1945 , contra Nagasaki ${ }^{10}$.

Apesar das justificativas norte-americanas para o ataque, especialmente de que aquele ato anteciparia o fim da guerra contra o Japão, reduzindo o número de baixas em ambos os $\operatorname{lados}^{11}$, há dois elementos que, aparentemente, foram decisivos para a decisão de utilizar a nova bomba: a demonstração de força contra os soviéticos e o caráter experimental do ataque.

8 ABRANCHES, C.A. Dunshee de. Proscrição das armas nucleares. São Paulo: Freitas Bastos, 1964, , p. 79

9 Ver descrição de Abranches, Ibidem, p. 78.

10 Para um interessante relato histórico de detalhes dos ataques, e de personagens importantes e sobreviventes, ver: PELLEGRINO, Charles. O último trem de Hiroshima: os sobreviventes olham para trás. Tradução de Angélica Freitas. São Paulo: Leya, 2010.

11 Interessante notar que diversos estudos esvaziam essa justificativa, destacando que a falência da estratégia diplomática nipônica com o envolvimento soviético no front oriental foi mais decisiva do que o uso das bombas nucleares. Cf. KUZNICK, Peter J. A Tragic Life: Oppenheimer and the Bomb. Disponível em: <https://www.armscontrol.org/print/1851>. Acesso em: 21 Dez. 2014. 
Esse último aspecto pode ser constatado pelo fato de que Hiroshima e Nagasaki aparentemente foram poupadas de ataques aéreos para que os efetivos efeitos da nova bomba fossem avaliados de modo mais evidente.

Conforme o relato de um sobrevivente chamado Tadataka Sasaki, enquanto Tóquio, certamente mais bem protegida, estava sendo castigada duramente, o primeiro alvo atômico, localidade que reunia importantes pontos estratégicos para os esforços de guerra japoneses, era mantido ileso:

Em primeiro de fevereiro, retornei para Hiroshima. Os ataques aéreos em Tóquio continuaram até 10 de março, quando os EUA efetuaram um vasto bombardeio sobre a cidade, matando mais de cem mil pessoas. Quando retornei a Hiroshima, a cidade estava bonita, intocada, como se nada estivesse acontecendo no Japão. Aquela cena foi estranha para mim 12 .

Quaisquer que fossem as justificativas, abriu-se uma nova era para a humanidade com o lançamento daquelas bombas, cujo potencial devastador nunca permitiu que fossem utilizadas desde então ${ }^{13}$.

Independente das reais causas para a rendição incondicional japonesa, deve ser reconhecido que os ataques nucleares representaram uma saída para evitar uma humilhação completa do Japão. "Poder-se-ia argumentar - como fez o imperador japonês na proclamação em que anunciava a rendição - que se tratava de uma nova e desumana descoberta que arrebataria um número sem conta de vidas inocentes [...] e que considerações humanitárias, mais do que o reconhecimento de uma derrota, levaram o Japão a decidir por um fim à guerra" ${ }^{14}$.

12 SASAKI, Tadataka Asking Young People to Create a Peaceful Country. In: An anthology of the experiences of Hiroshima Atomic Bomb victims. Shimonoseki: Yoshimura, 2010, p. 13, tradução do original: "On the 1st of February, I returned to Hiroshima. The air raids in Tokyo continued until the 10th of March, when the U.S. made a huge air raid on the city, killing over a hundred thousand people. When I returned to Hiroshima, the city was beautiful, untouched, like nothing had ever happened in Japan. It was a strange scene for me".

13 BUNDY, McGeorge; CROWE Jr., William J.; DRELL, Sidney D. Reducing Nuclear Danger - The road away from the brink. New York: Council on foreign Relations Press , 1993, p. 8.

14 MCINNIS, Edgard. História da II Guerra Mundial - sexto e último ano de operações. Tradução de Homero de Castro Jobim. Porto Alegre: Globo, 1962, p. 246-247. 
Esse potencial devastador, como já foi analisado nos capítulos anteriores ${ }^{15}$, subverteu as bases em que se assentavam o direito e as relações internacionais. A guerra passava a possuir resultados absolutos obtidos por um único golpe instantâneo ${ }^{16}$.

Mesmo princípios universalmente consagrados no direito internacional, especificamente no que tange às normas que regulam os conflitos armados, foram colocados em xeque diante da existência e do uso das armas nucleares.

Era difícil, se não impossível, enxergar alguma compatibilidade entre elas e o conceito central das normas que regulam os conflitos armados, a regra estabelecida no art. 22 das regulações de Haia e reafirmadas no art. 35 do Protocolo de Genebra I, de 1977: “o direito dos beligerantes de adotar os meios de ferir o inimigo não são ilimitados" ${ }^{17}$.

O testemunho dos horrores causados pelas bombas atômicas imediatamente sensibilizou a sociedade internacional para os riscos dessa nova ameaça.

É digno de nota que os próprios cientistas responsáveis pela produção da bomba, equipe composta, dentre outros, por Albert Einstein, Robert Oppenheimer, Niels Bohr e Leo Szilard, criaram a Federação dos Cientistas (Atômicos) Americanos - FAS, cujo principal objetivo era o de informar os líderes e o público dos Estados Unidos sobre a realidade das armas nucleares:

\begin{abstract}
Nessa época, Washington tinha a ilusão de que guardava um grande segredo e de que era possível não só deter a posse exclusiva da bomba como também decidir se a utilizaria ou não. [...] A FAS alertou o povo americano em termos simples e claros. Em essência, o alerta era de que em pouco tempo o mundo inteiro disporia de armas nucleares. E mais: não havia segredos nessa matéria e tampouco defesas. A era nuclear havia chegado e não podia ser ignorada ${ }^{18}$.
\end{abstract}

15 SAMPAIO, Maria Feliciana Nunes Ortigão de. O Tratado de Proibição Completa dos Testes Nucleares $(C T B T)$ : Perspectivas para sua entrada em vigor e para a atuação diplomática brasileira. Brasília: Alexandre de Gusmão, 2012, p. 33.

16 BULL, Hedley. A sociedade anárquica. Tradução de Sérgio Bath. São Paulo: Universidade de Brasília, 2002, p. 61-62.

17 OTT, David H. Public International Law in the Modern World. Londres: Pitman, 1987, p. 318. A incompatibilidade das armas nucleares e os princípios que regulam os conflitos armados serão objeto de análise do capítulo 1, da terceira parte deste trabalho.

18 LANGEWIESCHE, William. O bazar atômico - a escalada do poderio nuclear. Tradução de J. Viegas. São Paulo: Cia. das Letras, 2007, p. 16. 
Os cientistas da FAS formularam propostas sobre como se deveria lidar com o tema. Albert Einstein, nesse sentido, chegou a tangenciar princípios kantianos, ainda que sem o necessário aprofundamento em questões a respeito da viabilidade de implantá-los, ao sugerir que se criasse um governo global, que resultaria do desmantelamento voluntário dos Estados soberanos ${ }^{19}$.

Também no plano legislativo doméstico foram verificadas inciativas contrárias às armas nucleares, conforme o Projeto de Resolução $n^{\circ} 336$, apresentado pelo congressista Ludlow, em 5 de setembro de 1945, "exigindo ação dos Estados Unidos para banir a bomba atômica como um instrumento de guerra" 20 .

É curioso notar certa ingenuidade das autoridades americanas em relação à nova arma, tendo divulgado abertamente detalhes sobre a tecnologia por detrás dela. Uma vez que todo desenvolvimento tecnológico decorre de conhecimentos científicos básicos e universais, quaisquer segredos sobre a nova tecnologia desapareceram pelo próprio uso da bomba, que demonstrava que aquele tipo de explosão era viável. Mas os EUA foram além ao divulgarem, no dia seguinte ao ataque nuclear, o famoso Relatório Smyth sobre a Energia Atômica ${ }^{21}$. Tratava-se de documento que abordava o uso da energia atômica para fins militares, coordenado por Henry De Wolf Smyth ${ }^{22}$, em que eram descritos os métodos de obtenção do urânio 235, o processo de preparação do plutônio e outros problemas práticos relacionados com a fabricação da bomba ${ }^{23}$.

Essa ingenuidade logo deu lugar à percepção de que aquele assunto deveria ser considerado estratégico para a segurança nacional. Assim, contra a transparência irrestrita, em 1946 foi promulgada a Lei McMahon, que decretou que os EUA nunca mais dividiriam segredos nucleares com qualquer país estrangeiro ${ }^{24}$, e que estabeleceu pena de morte para quem divulgasse quaisquer informações técnicas sobre o tema ${ }^{25}$.

19 LANGEWIESCHE, William. O bazar atômico - a escalada do poderio nuclear. Tradução de J. Viegas. São Paulo: Cia. das Letras, 2007, p. 16.

20 ABRANCHES, C.A. Dunshee de. Proscrição das armas nucleares. São Paulo: Freitas Bastos, 1964, , p. 115 .

21 ZUCKERMAN, Solly. Nuclear Illusion and Reality. New York: The Viking, 1982, p. 17.

22 Atomic energy for military purposes (The Smyth Report). By Henry De Wolf Smyth. 1st July, 1945. Disponível em: <http://www.atomicarchive.com/Docs/SmythReport/>. Acesso em: 8 Nov. 2014.

23 ABRANCHES, op. cit., p. 87.

24 ZUCKERMAN, op. cit.,p. 83.

25 SOARES, Guido Fernando Silva. As salvaguardas nos acordos nucleares. São Paulo: Bushatsky, 1977, p. 30 . 
Internacionalmente, ainda que sem a pretensão idealista dos integrantes da FAS, não tardou a surgir um movimento para se dar um tratamento sério e adequado à questão nuclear, como dá conta a Declaração de Washington, de 1945, proferida em conjunto pelos EUA, Inglaterra e Canadá.

Naquela declaração, fora manifestado o desejo de uma ação internacional com o objetivo de evitar o uso destrutivo da energia nuclear e promovê-la para fins pacíficos e humanitários e, paralelamente, de se eliminarem as armas atômicas, com o estabelecimento de garantias para a proteção da sociedade internacional contra possíveis violações de compromissos a tal respeito ${ }^{26}$.

Contudo, essas iniciativas esbarravam na incapacidade do principal foro internacional que havia para tratar daquele tema. Abranches ${ }^{27}$ descreve com lucidez que a Carta das Nações Unidas, por ter sido desenvolvida antes do fim da Segunda Guerra, "não refletia qualquer das consequências que a liberação e o controle da energia nuclear e a sua aplicação para fins bélicos acarretaram para as relações internacionais e para a continuidade do uso da força pelos Estados". ${ }^{28}$ Justamente por essa circunstância é que não há qualquer previsão específica sobre armas atômicas na Carta $^{29}$, e que sua regulamentação sobre a exceção que autoriza o uso da força pelos Estados, o art. 51 que reserva essa possibilidade para o exercício do direito da autodefesa, é incompatível com a situação em que se está diante de ameaça ou ataque nuclear.

Apesar dessa deficiência da Carta, é emblemático que a primeira resolução aprovada pela Assembleia Geral da ONU tenha determinado o estabelecimento de uma comissão para lidar com os problemas decorrentes da descoberta da energia atômica ${ }^{30}$.

26 ACCIOLY, Hildebrando; NASCIMENTO E SILVA, Geraldo do; CASELLA, Paulo Borba. Manual de Direito Internacional Público. 16. ed. São Paulo: Saraiva, 2008, p. 852

27 ABRANCHES, C.A. Dunshee de. Proscrição das armas nucleares. São Paulo: Freitas Bastos, 1964, p. 54-55.

28 É interessante notar, a título de ilustração, que não havia um plano de que os cinco membros permanentes do Conselho de Segurança devessem ser as únicas cinco potências nucleares reconhecidas pelo TNP. Cf. REGEHR, Ernie. The Security Council and nuclear development In: BOULDEN, James; THAKUR, Ramesh Chandra; WEISS, Thomas George (Coords.). The United Nations and Nuclear Orders. Tokyo: United Nations University, 2009, p. 31.

29 BOULDEN, James; THAKUR, Ramesh Chandra;WEISS, Thomas George. The United Nations and nuclear orders: Context, foundations, actors, tools, and future prospects. In: BOULDEN, James; THAKUR, Ramesh Chandra; WEISS, Thomas George (Coords.). The United Nations and Nuclear Orders. Tokyo: United Nations University, 2009, p. 3.

30 Disponível em: <http://daccess-dds-ny.un.org/doc/RESOLUTION/GEN/NR0/032/52/IMG/NR0032 52.pdf?OpenElement $>$. Acesso em: 9 dez. 2014. 
A resolução ainda exortava os Estados membros a (i) estender o intercâmbio de informações científicas para fins pacíficos de seu uso, (ii) controlar a energia atômica apenas para fins pacíficos, (iii) eliminar as armas nucleares e outras armas de destruição em massa, e (iv) estabelecer salvaguardas por meio de inspeções e outros mecanismos para proteger os Estados contra violações dessas obrigações ${ }^{31}$.

Contudo, essas propostas não poderiam ser levadas a cabo diante da ausência de uma autoridade supranacional permanente. Essa carência, que alimentava um clima de desconfiança internacional ${ }^{32}$, foi duramente sentida ainda no estágio incipiente dos esforços internacionais pelo desarmamento nuclear, quando projetos apresentados tanto pelos EUA quanto pela URSS foram inviabilizados pelos próprios Estados. A causa desse insucesso decorreu da prevalência da política do poder sobre o direito internacional.

A proposta americana, chamada de Plano Baruch, apresentado em 1946, rapidamente mencionado em capítulo anterior neste trabalho, consistia na criação da "Autoridade do Desenvolvimento Atômico', que funcionaria sob a direção das Nações Unidas. Essa autoridade teria controle completo sobre todas as fases da energia atômica, assim como seria proprietária de todas as atividades da energia atômica potencialmente perigosas para a segurança mundial. Como passos práticos para a implantação desse plano, a partir da criação de uma tal autoridade, haveria vinculação dos Estados à cessação de manufatura de bombas e à destruição das já existentes. O plano ainda previa o cancelamento do poder de veto em temas relativos à energia nuclear e a aplicação de sanções a ele relativas, deixando a Rússia em grande desvantagem ${ }^{33}$.

Caso o plano tivesse sido acolhido, teria sido confirmada a supremacia atômica daquele país, além de afastada a ameaça representada pela competição russa na área. A reação natural, como cita Wight, foi a insatisfação das demais nações à limitação dos armamentos, algo que dificultaria suas tentativas de alterarem o equilíbrio do poder em seu

31 A Assembleia Geral da ONU, apesar de suas resoluções não possuírem caráter vinculante, aprovou diversas outras resoluções sobre o tema. É interessante notar a ênfase dada na Resolução 1653(XVI) sobre o uso de tais armas representar uma violação direta da Carta, uma ação excessiva em relação aos objetivos de conflitos armados e contrária às leis da humanidade. Disponível em: <http://daccess-ddsny.un.org/doc/RESOLUTION/GEN/NR0/167/06/IMG/NR016706.pdf?OpenElement>._Acesso em:2 Dez. 2014.

32 BUNDY, McGeorge; CROWE Jr., William J.; DRELL, Sidney D. Reducing Nuclear Danger - The road away from the brink. New York: Council on foreign Relations Press, 1993, p. 15.

33 ABRANCHES, C.A. Dunshee de. Proscrição das armas nucleares. São Paulo: Freitas Bastos, 1964, p. 119. 
favor e, consequentemente, melhorarem sua posição relativa ${ }^{34}$. Deste modo, houve por parte dos demais Estados um posicionamento desconfiado contra as efetivas intenções por detrás da iniciativa ${ }^{35}$.

Discordando das bases inseridas no Plano Baruch, a URSS apresentou um plano substitutivo conhecido como Plano Gromiko ${ }^{36}$, o qual invertia a ordem prevista no Plano Baruch, primeiro prevendo a destruição das armas nucleares e paralisando novas produções para uma posterior criação de instituição de controle. Naturalmente, quem se opôs a esse plano foram os americanos ${ }^{37}$.

Nos anos que se seguiram, não houve nenhuma cooperação efetiva no âmbito nuclear para fins pacíficos entre os EUA e os demais países. Ao fim e ao cabo, todos sabiam que a falta de confiança recíproca representava um obstáculo para que qualquer projeto sobre o tema tivesse algum sucesso.

Esses dois projetos são interessantes porque ilustram bem um viés de conduta dos Estados que se vem repetindo até hoje, marcado por duplos padrões, seletividade discriminatória e inconsistências que apenas alimentam a falta da confiança necessária para haver qualquer avanço concreto sobre a questão.

Uma das maiores mostras desse duplo padrão pode ser colhida pelo governo de Eisenhower. Este é sempre lembrado pelo seu corajoso discurso 'Atoms for Peace', já referido aqui como o embrião do que veio a se tornar a Agência Internacional de Energia Atômica. Paradoxalmente, contudo, durante o período em que esteve na presidência dos EUA, o arsenal americano pulou de 1.436 para 20.464 ogivas nucleares ${ }^{38}$. Pode-se afirmar,

34 WIGHT, Martin. A política do poder. Tradução de Carlos Sérgio Duarte. Brasília: UnB, 1985, p. 169170.

35 Ibidem, p. 82.

36 MAGALHÃES JÚNIOR, Japy Montenegro; MARQUES, Fernando Mário Rodrigues. A proliferação nuclear. Revista de Administração Pública, Rio de Janeiro, v. 12, n. 4, p.173-197, out./dez.1978. Disponível em: <www.spell.org.br/documentos/download/15540>. Acesso em; 15 nov. 2014, p. 176.

37 ABRANCHES, C.A. Dunshee de. Proscrição das armas nucleares. São Paulo: Freitas Bastos, 1964, p. 120.

38 SAMPAIO, Maria Feliciana Nunes Ortigão de. O Tratado de Proibição Completa dos Testes Nucleares $(C T B T)$ : Perspectivas para sua entrada em vigor e para a atuação diplomática brasileira. Brasília: Alexandre de Gusmão, 2012, p. 38. 
então, que a falta de confiança alimentada pelos próprios Estados foi e segue sendo o primeiro obstáculo a ser vencido para se falar em desarmamento nuclear ${ }^{39}$.

Com a falência dessas tentativas, não tardou muito tempo para que, no lugar do banimento, fosse acelerada a proliferação nuclear, inicialmente para os outros quatro membros permanentes do Conselho de Segurança da ONU, de maneira explícita, e, décadas depois, para a Índia, Paquistão e Israel, ainda que este último sempre tenha preferido adotar uma postura dúbia sobre possuir ou não capacidade militar nuclear em nível operacional ${ }^{40}$.

O registro da primeira explosão atômica realizada pela URSS data de 29 de agosto de 1949, com o teste da bomba 'Joe 1' ${ }^{41}$. Na sequência, a Inglaterra, depois de ter decidido que a aquisição de armas nucleares a fortaleceria em foros internacionais ${ }^{42}$, tornou-se $o$ terceiro Estado a testar armas nucleares, em 3 de outubro de $1952^{43}$. Completando o clube nuclear do TNP, a França e a China tornaram-se potências nucleares respectivamente em 1960 e $1964^{44}$.

O resultado dessa proliferação nuclear, mesmo que apenas verificada entre poucos Estados, foi muito negativo para a humanidade, seja em termos do número de ogivas fabricadas e mantidas, seja pela elevação absurda de seu potencial destrutivo.

Quando se se refere ao efeito negativo para a humanidade, não se está mencionando qualquer aspecto filosófico e abstrato sobre o tema, igualmente relevantes e possíveis de serem debatidos. Mas esse debate é desnecessário, bastando verificar-se a ameaça de contaminação representada pela enorme quantidade de radiação liberada pelos mais de 2000 testes atômicos realizados desde o ataque contra Hiroshima ${ }^{45}$.

39 BUNDY, McGeorge; CROWE Jr., William J.; DRELL, Sidney D. Reducing Nuclear Danger - The road away from the brink. New York: Council on foreign Relations Press, 1993, p. 33.

40 LAFER, Celso, Comércio, Desarmamento e Direitos Humanos: reflexões sobre uma experiência diplomática. 2. ed. São Paulo: Paz e Terra, 2006, p. 111. As questões norte-coreanas e iranianas serão objeto de análise específica, e não foram inseridas nessa referência por possuírem características distintas das que marcaram a proliferação nuclear no subcontinente indiano e em Israel.

41 UNITED NATIONS. International Day against Nuclear Tests. 29 August. Disponível em: http://www.un.org/en/events/againstnucleartestsday/history.shtml\#a21. Acesso em: $21 \mathrm{dez} .2014$.

42 STODDART, Kristan. Losing an empire and finding a role - Britain, the USA, NATO and Nuclear Weapons, 1964-70. Hampshire: Palgrave Macmillan, 2012, p. 19-35.

43 UNITED NATIONS. International Day against Nuclear Tests. 29 August. Disponível em: http://www.un.org/en/events/againstnucleartestsday/history.shtml\#a21. Acesso em: 21 dez. 2014.

44 Ibidem.

45 LOUKA, Ellie. Nuclear Weapons, justice and the law. Cheltenham: Edward Elgar, 2011, p. 15. 
$\mathrm{O}$ acelerado crescimento da quantidade de ogivas nucleares pelo mundo igualmente representava grandes preocupações, especialmente quando lembramos que seu controle estava submetido à política de dissuasão nuclear, com as falhas e precariedades a ela inerentes, conforme foi debatido na parte I desta dissertação.

É um pouco fluida a informação precisa do número exato de ogivas nucleares no mundo, mas os dados existentes apontam para quantidades absurdas. Zuckerman, referindo-se ao Relatório das Nações Unidas sobre o Estudo Amplo de Armas Nucleares, de 1980, menciona que o estoque atômico girava, à época, em torno de 40.000 ogivas. De acordo com esse número e a potência estimada dos armamentos, a humanidade teria sido agraciada com o equivalente a 3 toneladas de TNT per capta ${ }^{46}$.

Em estudo datado de 1991, já se apontava que o estoque mundial havia crescido ao patamar de 50.000 ogivas nucleares ${ }^{47}$. Tamanho potencial torna verossímil a alegação de que a humanidade havia adquirido o poder de se destruir completamente.

É verdade tem havido redução da quantidade de ogivas no mundo, conforme se vê nos dados mais próximos da atualidade constantes da tabela a seguir:

NÚMERO DE OGIVAS POR PAÍS ${ }^{48}$

\begin{tabular}{|c|c|}
\hline PAÍS & OGIVAS NUCLEARES \\
\hline EUA & Em torno de 9400, das quais 4200 aguardam desmantelamento \\
\hline Rússia & $\begin{array}{c}\text { Em torno de 10000, das quais grande parte aguarda } \\
\text { desmantelamento }\end{array}$ \\
\hline Reino Unido & 185 \\
\hline França & Menos de 300 \\
\hline China & Em torno de 240 \\
\hline Israel & $100-200$ \\
\hline Índia & $60-70$ \\
\hline Paquistão & $70-90$ \\
\hline Coreia do Norte & Menos de 5 \\
\hline
\end{tabular}

46 ZUCKERMAN, Solly. Nuclear Illusion and Reality. New York: The Viking, 1982, p. 18.

47 Committee on International /security and Arms Control - National Academy of Sciences. The future of the U.S. - Soviet nuclear relationship. Washington: National Academy, 1991, p. 15.

48 LOUKA, Ellie. Nuclear Weapons, justice and the law. Cheltenham: Edward Elgar, 2011, p. 13 - fontes estimativas do Conselho de Defesa das Reservas Naturais e Federação dos Cientistas Americanos. 
Ainda que o número total de ogivas tenha diminuído, não se pode ignorar que essa redução traz ganho apenas aparente, já que o desmantelamento dos arsenais é restrito a itens obsoletos ou de pouca utilidade estratégica ${ }^{49}$.

A corrida armamentista, além de ter se refletido no tamanho dos arsenais criados, propiciou ao mundo o testemunho de armas muito mais destruidoras do que as já terríveis bombas que haviam sido lançadas sobre o Japão.

O poderio destrutivo das armas utilizadas na Segunda Guerra era medido em quilotons, ou seja, cada unidade equivalia a mil toneladas de TNT, o elemento químico comumente usado para fabricação de bombas. Estima-se que as que foram lançadas contra Hiroshima e Nagazaki possuíam, respectivamente, 15 e 20 quilotons. Com o advento das armas termonucleares, cuja tecnologia baseia-se na energia liberada pela fusão nuclear à base de hidrogênio, também conhecidas como Bombas $\mathrm{H}$, a escala saltou para a contagem em megatons, ou seja, cada unidade representava o potencial destrutivo equivalente a um milhão de toneladas de TNT.

Conforme algumas simulações de ataques contra centros urbanos ao longo da década de 1960, a explosão de um artefato com apenas um megaton de potência produziria efeitos catastróficos. Por exemplo, em 1960, Birmingham possuía um milhão de habitantes. No caso de um ataque com uma bomba daquele tipo no nível do solo, haveria uma destruição completa numa área compreendida pelo raio de aproximadamente 3,5 quilômetros do centro da explosão, sem a possibilidade de qualquer sobrevivente. Um terço dos habitantes seria imediatamente morto, ou morreria pela dose letal de radiação nos primeiros dois dias. Apenas metade da população original sobreviveria em condições de cooperar nas medidas para lidar com o caos ${ }^{50}$.

Outra simulação de um ataque semelhante contra a cidade norte-americana de Detroit, em 1979, que à época possuía 4.3 milhões de habitantes, indica que um quarto da população morreria instantaneamente, e que aproximadamente 500.000 feridos exigiriam

49 Sobre o caráter limitado das reduções bilaterais negociadas entre EUA e Rússia, Cf. BUNDY, McGeorge; CROWE Jr., William J.; DRELL, Sidney D. Reducing Nuclear Danger - The road away from the brink. New York: Council on foreign Relations Press, 1993, p. 17, tradução livre do original em inglês: "Nenhuma redução já considerada pelos dois governos vai alterar a continuidade da realidade de impasse estratégico, e nem se espera que a Rússia ou os EUA venham a abdicar de sua capacidade de sobrevivência para ataques secundários num futuro próximo".

50 ZUCKERMAN, Solly. Nuclear Illusion and Reality. New York: The Viking, 1982, p. 27-28. 
um esforço imensurável das estruturas de saúde, sendo prevista a superlotação de todas as instalações médicas dos EUA para atendê-los ${ }^{51}$.

Para se ter uma ideia mais clara do inaceitável status que havia sido criado pelas principais potências nucleares em termos de capacidade destrutiva, essas simulações lidavam com ataques de artefatos com apenas um megaton de capacidade explosiva. Contudo, a ogiva mais poderosa de que se tem notícia de uso teve sua capacidade estimada em 58 megatons. Chamava-se Tzar, e foi testada em 1962, pela URSS. Há relatos de que Khrushchev teria declarado que a bomba deveria ser maior, mas, se o fosse, estima-se que teriam sido destruídas janelas em Moscou, mesmo que situadas a aproximadamente seis mil e quatrocentos quilômetros do local do teste ${ }^{52}$.

Esse foi o resultado quantitativo e qualitativo da corrida armamentista propiciada pela estagnação de qualquer iniciativa pelo controle ou banimento das armas nucleares.

Posteriormente, contudo, verificou-se uma crescente elaboração de mecanismos e tratados para limitar ou proibir a aquisição, produção e posse de armas nucleares. $\mathrm{Na}$ realidade, também essa elaboração decorreu, em grande parte, de propostas das principais potências que se alinhavam a suas próprias agendas e interesses, não sendo fruto da percepção de que o mundo seria mais seguro caso não existissem armas nucleares. Segundo More,

\begin{abstract}
a corrida armamentista sobre armas nucleares correu livremente até que as potências (juntaram-se aos EUA e à URSS, a França, Reino Unido e China) decidiram que já possuíam armas suficientes em estoque para exterminar algumas centenas de vezes a vida em todo o planeta, fazendo inaugurar uma série de tratados multilaterais de não-proliferação ou de proibição de teste deste tipo de armas ${ }^{53}$.
\end{abstract}

$\mathrm{Na}$ mesma toada das inconsistências observadas ainda na década de 40, esses tratados eram respostas das principais potências contra ameaças que identificavam à estabilidade de sua posição internacional. Assim, a "cada novo caso de proliferação nuclear

51 ZUCKERMAN, Solly. Nuclear Illusion and Reality. New York: The Viking, 1982, p. 30.

52 Ibidem, p. 16-17.

53 MORE, Rodrigo Fernandes. O Desarmamento no sistema de segurança coletiva da ONU. 2005.Tese (Doutorado) - Faculdade de Direito, Universidade de São Paulo, São Paulo, 2002, p. 59. 
a comunidade internacional, impulsionada pelos P5, criava mais um elemento de controle. [...] acenava-se com vagas promessas de desarmamento, nunca de fato cumpridas" 54 .

Desse período inicial merecem destaque o já referido Tratado de Moscou, de 1963, que impunha restrições contra testes nucleares, e o Tratado de Não-Proliferação Nuclear (TNP), datado de 1968. Em termos institucionais, é importante destacar a Agência Internacional de Energia Atômica, criada em 1957, cuja atuação complementa, como será objeto de análise no capítulo 3 , desta segunda parte da dissertação, a funcionalidade do TNP.

Essas iniciativas, entretanto, eram pautadas pelo contexto da época, como foi descrito mais acima, especialmente no que tange a uma instrumentalização por parte das nações nucleares de um discurso que propiciaria a aceitação dos demais países. De um lado, acenava-se com esperanças em prol do desarmamento, mas, de outro, mantinha-se o status quo. Tal inconsistência reflete-se, por exemplo, no próprio caráter discriminatório que se verifica na gênese do TNP, que reserva o direito a apenas alguns poucos Estados de desenvolverem e possuírem armas nucleares. Em contrapartida, os Estados nucleares armados assumiram a obrigação de se desarmarem, obrigação esta nunca levada a cabo efetivamente.

No capítulo a seguir será detalhadamente analisado o TNP, assim como suas falhas, mas é importante antecipar que, mesmo reconhecendo essas inconsistências naquele que é tido como o pilar central do regime de não proliferação nuclear, ainda assim ele deve ser celebrado como conquista importante na construção de um futuro idealizado de um mundo sem armas nucleares. Com efeito, os próprios mecanismos de revisão e avaliação periódicas do TNP, previstos em seus artigos VIII.3 e X.2, acabaram se mostrando meios importantes para que fossem ampliadas a pressão e as iniciativas em prol do desarmamento nuclear, seja por meio de propostas de novos tratados a ele complementares, seja por meio de projetos de reforma do próprio TNP.

Desse modo, mesmo que em ritmo lento, verifica-se que cada conquista acaba se refletindo em posições adquiridas nessa construção gradativa que, somadas a outras, alimentam a força do discurso contrário às armas nucleares.

54 SAMPAIO, Maria Feliciana Nunes Ortigão de. O Tratado de Proibição Completa dos Testes Nucleares $(C T B T)$ : Perspectivas para sua entrada em vigor e para a atuação diplomática brasileira. Brasília: Alexandre de Gusmão, 2012, p. 33. 
No lugar de criticar suas falhas e condenar o tratado, é melhor celebrar a conquista do TNP, mesmo imperfeito e precário, porque permite a consolidação de patamar qualitativo muito mais desenvolvido no tratamento dessa questão.

Verifica-se, aqui, uma constatação concreta de como o ideal kantiano da paz perpétua é útil para descrever a luta pelo desarmamento nuclear. Basta relembrar o que foi descrito pelo filósofo sobre o erro do prático, "na sua pretensão de que ele pretende ver antecipadamente a partir da natureza do homem que ele nunca irá querer aquilo que seja necessário para atingir a paz perpétua" 55 .

A descrição feita neste capítulo da evolução e consolidação da assim chamada era nuclear foi importante para se compreender o contexto em que desenvolveram tratados e instituições que lidam com o tema do desarmamento nuclear, para se compreender melhor quais são as críticas existentes contra eles.

Nos próximos capítulos serão analisados os tratados e organismos internacionais relacionados ao tema do controle e banimento das armas nucleares, sempre sob o prisma dessa visão de construção kantiana. Contudo, para uma análise mais abrangente e que reflita adequadamente os desafios atuais relacionados ao tema, essa análise do aparato de não proliferação e tentativa de banimento das armas nucleares não se resumirá apenas aos tratados e organismos formalmente estabelecidos internacionalmente.

Apesar de ancorado nesses elementos, o regime de não proliferação, hoje em dia, conta com iniciativas não institucionais importantes para se lidar com ameaças que não poderiam ser enfrentadas apenas pelos tratados. Em primeiro lugar, porque "o equilíbrio não mais se baseia apenas em relações entre Estados-potências, mas na concorrência de outros Estados rebeldes e, principalmente, de atores não-estatais, como os terroristas, por uma parcela tecnicamente ilimitada de poder, no caso de poder militar, outrora privilégio de poucos Estados" ${ }^{56}$. Além disso, não é possível ignorar o risco representado pela ampliação dos Estados que dominam a tecnologia nuclear, mesmo que para fins civis. Seja pela ameaça de ataques terroristas contra suas instalações ou roubo de combustível nuclear,

55 KANT, Immanuel. À Paz Perpétua. Tradução de Marco Antônio Zingano. São Paulo: L\&PM Editores, 1989, p. 60-61.

56 MORE, Rodrigo Fernandes. O Desarmamento no sistema de segurança coletiva da ONU. 2005. Tese (Doutorado) - Faculdade de Direito, Universidade de São Paulo, São Paulo, 2002, p. 31-32. 
seja porque o domínio do uso da tecnologia nuclear facilmente pode ser utilizado para fins bélicos ${ }^{57}$.

Por essas razões é que, além das iniciativas formais, serão também objeto de análise as iniciativas não institucionalizadas formalmente nem convertidas em tratados internacionais.

57 LOUKA, Ellie. Nuclear Weapons, justice and the law. Cheltenham: Edward Elgar, 2011, p. 13. 


\section{O TRATADO DE NÃO PROLIFERAÇÃO DE ARMAS NUCLEARES}

\subsection{Considerações gerais e surgimento do TNP}

As iniciativas relacionadas à luta pelo desarmamento nuclear dividem-se, basicamente, em duas vertentes: não proliferação nuclear, ou seja, limitação dos Estados detentores de armas atômicas, e desarmamento propriamente dito.

Ambas as vertentes são consideradas complementares ${ }^{1}$, de um lado evitando-se maior número de possuidores de arsenais atômicos e, de outro, lutando-se para que os arsenais existentes sejam gradativamente diminuídos. As duas frentes são implementadas por meio de diversos tratados e organismos internacionais, que, como já foi indicado na introdução desta dissertação, conformam um verdadeiro microssistema normativo e institucional específico composto por tratados multilaterais, acordos bilaterais, resoluções, convenções etc.

Apesar de a Agência Internacional de Energia Atômica ter sido a primeira iniciativa concretizada na ordem internacional da não proliferação nuclear, iniciaremos nossa análise desse aparato por sua pedra fundamental, como é reconhecido o Tratado de NãoProliferação de Armas Nucleares (TNP), de $1968^{2}$.

Na realidade, o mais correto é identificar que o regime de não proliferação nuclear baseia-se essencialmente no tripé composto pelo TNP, pelo regime de salvaguardas regulado pela Agência Internacional de Energia Atômica (AIEA) e pelos acordos de controle de exportações de itens que podem servir para o desenvolvimento de programas nucleares $^{3}$. Esses três pilares atuam de modo complementar, sendo que as obrigações assumidas de acordo com o TNP são fiscalizadas por meio das salvaguardas impostas pela AIEA, que, diante de descumprimentos ou suspeitas de descumprimento, reporta-se ao Conselho de Segurança da ONU. Assim, o mecanismo de funcionamento desse regime é

1 É importante reconhecer que a energia direcionada aos esforços de não-proliferação é muito maior do que aquela canalizada para o desarmamento nuclear. As razões dessa diferença referem-se à própria estrutura do aparato internacional desenvolvido sobre a questão, já que, como será analisado ao longo desta parte do trabalho, os interesses dos Estados nuclearmente armados, que acabam prevalecendo, referem-se muito mais ao controle da proliferação do que ao abandono dessas armas.

2 FINLAY, Brian; GROSSMAN-VERMAAS, Rita. Technology proliferation, globalization and the UN. In: BOULDEN, James; THAKUR, Ramesh Chandra; WEISS, Thomas George (Coords.).The United Nations and Nuclear Orders. Tokyo: United Nations University, 2009.

3 LOUKA, Ellie. Nuclear Weapons, justice and the law. Cheltenham: Edward Elgar, 2011, p. 102. 
ancorado em resoluções do Conselho de Segurança da ONU, que, mesmo diante de meras suspeitas, pode aplicar sanções para impor o cumprimento de obrigações, partindo da inversão do ônus da prova que, atualmente, recai sobre os suspeitos de serem proliferadores $^{4}$.

Como foi observado no capítulo anterior, os esforços para prevenir a proliferação de armas nucleares surgiram no ano seguinte ao do primeiro uso de tais armas, conforme as propostas americanas e soviéticas de $1946^{5}$ visando a um controle internacional. Também como foi descrito no capítulo anterior, frustradas aquelas iniciativas e iniciada a corrida armamentista, que gradualmente inseria novos Estados no restrito clube das nações nucleares, as principais potências depararam-se com um contexto que ameaçava sua posição de destaque internacional.

Com efeito, as potências nucleares logo identificaram o paradoxo de que as guerras nucleares, não podendo ser ganhas, deveriam ser evitadas. Essa constatação, testada no seu limite por ocasião da crise dos mísseis em Cuba, associada ao risco de "verem esvair-se seu monopólio das armas nucleares ao longo das duas primeiras décadas do pós-guerra" acabou por incentivar os EUA e a URSS a buscarem um "espaço de cooperação e interesse comum na gestão oligárquica das questões ligadas às armas nucleares" 6 .

Há registros ${ }^{7}$ de iniciativas anteriores, como a de 1958, quando foi apresentado à Assembleia Geral da ONU um projeto que envolvia o estabelecimento de uma comissão para estudar os riscos decorrentes da proliferação nuclear. Apesar de esse projeto não ter sido levado adiante, a ideia acabou sendo mantida e debatida pela Comissão de Desarmamento das Dezoito Nações, que fixou princípios gerais relativos à necessidade de se evitar a proliferação. O resultado dessa iniciativa foi justamente a concepção do TNP.

4 A atuação do Conselho de Segurança e a inversão do ônus da prova dos assim chamados proliferadores será tema de análise detalhada no capítulo 3, desta segunda parte da dissertação.

5 BUNDY, McGeorge; CROWE JR, William J.; DRELL, Sidney D. Reducing Nuclear Danger: The road away from the brink. New York: Council on foreign Relations Press, 1993, p. 54.

6 LAFER, Celso. Comércio, Desarmamento e Direitos Humanos - reflexões sobre uma experiência diplomática. 2. ed. São Paulo: Paz e Terra, 2006, p. 117-118.

7 MAGALHÃES JÚNIOR, Japy Montenegro; MARQUES, Fernando Mário Rodrigues. A proliferação nuclear. Revista de Administração Pública, Rio de Janeiro, v. 12, n. 4, p. 173-197, out./dez.1978. Disponível em: <www.spell.org.br/documentos/download/15540>. Acesso em: 15 nov. 2014, p. 181. 
Segundo observa Miniuci ${ }^{8}$, a decisão das duas principais potências de patrocinarem o Tratado de Não-Proliferação Nuclear decorria do desígnio de congelarem as relações internacionais, evitando a diluição também de conhecimentos e tecnologia. Já nessa rápida contextualização identifica-se uma das principais raízes das críticas existentes contra o tratado, considerado antiquado porque remonta ao período do auge da guerra fria, e que se presta "à perpetuação da hegemonia militar das potências que já adquiriram a tecnologia nuclear" 9 . É forçoso reconhecer que análises desinteressadas não raro apontam que as fragilidades do TNP foram intencionalmente criadas por seus idealizadores. É digna de nota a descrição de James Thakur sobre esses problemas:

\begin{abstract}
Algumas das fraquezas do TNP não são apenas intrínsecas, mas intencionais. Por exemplo, a redação dos artigos I e II deliberadamente permite aos estados nuclearmente armados transferirem armas nucleares a outros países, ou seja, efetuar proliferação geográfica, desde que seja mantido o controle sobre elas. [...] Por não incluir um cronograma claro, vinculante, verificável e eficaz para as obrigações de desarmamento, ele temporariamente legitimou os arsenais nucleares então existentes. [...] Falhou no desenho de uma estratégia para lidar com não signatários e permitiu a retirada de um modo muito fácil. [...] Por não haver uma agência ou secretariado, o TNP depende das conferências de revisão a cada cinco anos para resolver problemas de implementação. Além disso, essas conferências baseiam-se na regra de consenso, que não atende à necessidade de adoção de resoluções para questões controvertidas ${ }^{10}$.
\end{abstract}

Essas imperfeições refletiram as preferências, ao menos da época, dos participantes principais do TNP ${ }^{11}$.

8 FERREIRA JÚNIOR, Geraldo Miniuci. O acordo nuclear Brasil-Alemanha. In: DANESE, Sergio França (Org.). Ensaios de História Diplomática do Brasil. Brasília: Fundação Alexandre de Gusmão/Ipri, 1989, p. 154. (Cadernos do IPRI, n. 2.). O autor refere-se, aqui, também ao caráter financeiro do controle da nova tecnologia, aspecto destacado por diversos autores. Cf. COIMBRA, Guilhermina L. A história e o desenvolvimento da energia nuclear no Brasil. In: GOMES, Fabio Luiz (Coord). Direito Internacional perspectivas contemporâneas. São Paulo: Saraiva, 2010, p. 223.

9 RAMINA, Larissa; CUNHA FILHO, Valter Fernandes da. Segurança Internacional. Curitiba: Juruá, 2013, p. 166. Para uma interessante ilustração de como os Estados poderosos regiam o sistema internacional conforme seus próprios interesses, cf. BYERS, M. A lei da guerra-direito internacional e conflito armado. Rio de Janeiro: Record, 2007, p. 192.

10 THAKUR, Ramesh. Has the good become the enemy of the best? In: BOULDEN; James, THAKUR, Ramesh Chandra; WEISS, Thomas George (Coords.). The United Nations and Nuclear Orders. Tokyo: United Nations University, 2009, p. 281-282.

11 BUNDY, McGeorge; CROWE JR, William J.; DRELL, Sidney D. Reducing Nuclear Danger: The road away from the brink. New York: Council on foreign Relations Press, 1993, p. 75. 
Ainda que não seja possível ignorar o caráter enviesado da gênese do tratado, pautado pelos interesses das potências nucleares, não se pode também esvaziar sua relevância como o "ápice da autocontenção internacional no que toca às armas nucleares" 12. O tratado "desempenhou função expressiva nesse assunto, resultado da constatação de que, sem a imposição de limites, a própria humanidade estaria em sério risco de ser eliminada da face da Terra" ${ }^{13}$.

Assim, mesmo que se reconheça no tratado a confirmação da "predisposição dos mais fortes a usarem sua base de poder para subjugar os mais fracos, impondo a observância de seus interesses", ele pode ser visto, igualmente, como resultado do "interesse comum das nações de preservarem o relacionamento pacífico entre elas, com o estreitamento de laços de amizade e de entendimento" ${ }^{14}$. Para que fosse aceito pelos demais Estados, aqueles que não possuíam armas nucleares, difundira-se a ideia de que o TNP representaria uma conquista em prol da segurança internacional, evitando a desestabilização das esferas de proteção representada pelos 'guarda-chuvas' nucleares mantidos e antagonizados pela URSS e pelos EUA.

Essa retórica era distante da realidade, já que, para aqueles que não possuíam armas atômicas e que se decidissem por uma política externa não submissa aos interesses das principais potências, o TNP não poderia ser considerado uma garantia de segurança, nunca deixando de ser um documento discriminatório que submetia o mundo aos interesses das nações nuclearmente armadas ${ }^{15}$. Tanto é assim que, em 1968, identificando a precariedade das garantias de segurança, o Conselho de Segurança, não por acaso, aprovou a Resolução $255^{16}$, que reconhecia que a agressão com armas nucleares ou sua ameaça contra um Estado não nuclear determinaria que o Conselho de Segurança, e seus membros permanentes nuclearmente armados, agissem imediatamente de acordo com as obrigações assumidas na Carta da ONU.

12 MAGAlhãeS, José Carlos de. Uma introdução. In: MERCADANTE, Araminta de Azevedo; MAGAlHÃES, José Carlos de (Coords.). Solução e Prevenção de litígios internacionais. São Paulo: NECIN - Projeto CAPES, 1998, p. 12.

13 Ibidem, p. 12.

14 Ibidem, p. 9.

15 MAGALHÃES JÚNIOR, Japy Montenegro;MARQUES, Fernando Mário Rodrigues. A proliferação nuclear. Revista de Administração Pública, Rio de Janeiro, v. 12, n. 4, p.173-197, out./dez.1978. Disponível em: <www.spell.org.br/documentos/download/15540>. Acesso em: 15 nov. 2014, p. 181-182.

16 UNITED NATIONS. Resolution 255 (1968). Question relating to measures to safeguard non-nuclearweapon states parties to the treaty on the non-proliferation of nuclear weapons. Disponível em: http://www.un.org/en/ga/search/view_doc.asp?symbol=S/RES/255(1968). Acesso em: 6 dez. 2014. 
Era justamente esse viés discriminatório o destacado pelos Estados que decidiriam se manter fora do tratado. Eles observavam que

a gestão da ordem nuclear apenas por cinco países se traduzia numa situação na qual a segurança dos poucos, baseada na dissuasão nuclear, não representava a segurança de todos. [...] Em síntese, contestavam no plano da legitimidade [...] que, na perspectiva dos que não eram grandes potências, a ordem por elas construída era, além de precária e instável, injusta e especialmente ameaçadora para os que não estavam cobertos por um guarda-chuva nuclear ${ }^{17}$.

Mello, nesse sentido, recorrendo a Mário Pessoa, chega a afirmar que o TNP criava uma nova forma de colonialismo ${ }^{18}$.

Justamente pelas críticas do país contra o viés discriminatório, e a opção nacional pelo menor alinhamento às tentativas de controle dos Estados nuclearmente armados sobre o tema, buscando maior autoafirmação internacional, é que o Brasil recusou-se a assinar o TNP, postura mantida durante três décadas ${ }^{19}$.

Para se compreender melhor essas questões polêmicas, passemos à análise das provisões do TNP.

\subsection{Breve descrição dos artigos que compõem o TNP}

O Tratado de Não Proliferação de Armas Nucleares foi aberto para assinatura em Londres, Moscou e Washington, no dia $1^{\mathrm{o}}$ de julho de 1968, tendo entrado em vigor em 5 de março de 1970, depois de observadas as condições estabelecidas no artigo IX.3, com a ratificação por todos os Estados nuclearmente armados e mais 40 Estados não nucleares. Esse artigo é relevante porque é nele que se verifica o critério estabelecido para identificar

17 LAFER, Celso. Comércio, Desarmamento e Direitos Humanos - reflexões sobre uma experiência diplomática. 2. ed. São Paulo: Paz e Terra, 2006, p. 118-119.

${ }^{18}$ MELLO, Celso D. de Albuquerque.. Curso de Direito Internacional Público. 15. ed. São Paulo: Renovar, 2004, p. 1486. v.2.

${ }^{19}$ FERREIRA JÚNIOR, Geraldo Miniuci. O acordo nuclear Brasil-Alemanha. In: DANESE, Sergio França (Org.). Ensaios de História Diplomática do Brasil. Brasília: Fundação Alexandre de Gusmão/Ipri, 1989, p. 157. (Cadernos do IPRI, n. 2.) 
uma nação nuclearmente armada como "aquela que tenha fabricado e provado uma arma nuclear ou qualquer outro engenho nuclear explosivo antes de $1^{\circ}$ de janeiro de $1967^{, 20}$.

Atualmente, o tratado conta com o expressivo número de 190 Estados partes ${ }^{21}$, uma das razões para que seja reconhecido como o mais bem sucedido acordo de controle de armamentos da história mundial $^{22}$.

Ele não é muito extenso, composto de apenas onze artigos, sendo que sua essência é uma barganha entre os Estados nucleares e os Estados não nucleares. Estes assumem a obrigação de não se armarem nuclearmente, enquanto aqueles se obrigam a se desarmar e a cooperar com iniciativas do uso da energia nuclear para fins civis. É o que se depreende de seus onze $\operatorname{artigos}^{23}$.

Enquanto o artigo I estabelece que os Estados nuclearmente armados não transferirão armas ou explosivos nucleares aos Estados não nucleares, nem cooperarão para que estes as fabriquem ou adquiram, o art. II determina que os Estados não nucleares não poderão receber armas ou explosivos nucleares, nem fabricá-los ou adquiri-los.

O artigo III é de relevância fundamental para a funcionalidade do tratado, estabelecendo que todos os Estados não nucleares deverão submeter seus materiais e atividades nucleares ao regime de salvaguardas imposto pela Agência Internacional de Energia Atômica. Como será analisado no próximo capítulo, as salvaguardas e as inspeções realizadas para verificar o respeito dos Estados a elas constituem elemento central no controle da proliferação nuclear.

O artigo IV é relevante porque nele se prevê a obrigação de todos os Estados partes de facilitarem e integrarem o intercâmbio de equipamentos, materiais e informações tecnológicas e científicas para o uso pacífico da energia nuclear. Essa previsão é importante incentivo para a adesão de Estados não nuclearmente armados, que poderiam, ainda assim, desenvolver programas civis de uso da energia nuclear. Contudo, por não possuir um caráter mandatório, também essa obrigação foi interpretada pelas potências

20 RANGEL, Vicente Marotta. Direito e Relações Internacionais, 7. ed. São Paulo: RT, 2002, p. 229.

21 UNODA (United Nations Office for disarmament affairs). Treaty on the Non-Proliferation of Nuclear Weapons. Opened for signature at London, Moscow and Washington: 1 July 1968. Disponível em: http://disarmament.un.org/treaties/t/npt. Acesso em: 9 dez. 2014.

22 THAKUR, Ramesh. India's nukes pose paradox. In:__. War in our time - reflections on Iraq, terrorism and weapons of mass destruction. Tokyo: United Nations University, 2007, p. 100.

23 RANGEL, op. cit., p. 224-230. 
nucleares, que selecionam subjetivamente os Estados com quem aceitam cooperar nessa área. Essa seletividade, assim como o caráter discriminatório essencial do tratado e a relutância das nações nucleares de se desarmarem, constituem fatores de fragilidade e enfraquecimento do tratado, como será analisado mais à frente.

$\mathrm{O}$ artigo $\mathrm{V}$ refere-se às aplicações pacíficas de explosões nucleares, previsão sem maior utilidade porque, pelos efeitos deletérios causados por qualquer detonação, não se trata de uma prática comum, tanto que não foi possível obter referências de sua realização.

O artigo VI, diferentemente, é altamente polêmico e objeto de intenso debate internacional, à medida que nele se determina que todas as partes deverão estabelecer negociações em boa-fé para as medidas efetivas relacionadas com a cessação da corrida às armas nucleares e com o desarmamento nuclear, bem como negociações para um tratado relativo ao desarmamento nuclear geral e completo, sob o estrito e efetivo controle internacional.

Como se sabe, até hoje não houve qualquer avanço significativo no que toca ao cumprimento dessas obrigações. A relutância nisso, especialmente a dos Estados nuclearmente armados, acaba apenas reforçando as críticas contra o TNP, assim como elevando a ameaça de aumento da proliferação nuclear.

O artigo VII não impõe obrigações, mas representa um incentivo a que sejam estabelecidos acordos regionais para a criação de zonas livres de armas nucleares, acordos que se colocam como relevantes instrumentos para o desarmamento nuclear, conforme será analisado no capítulo 4 , desta segunda parte do trabalho.

$\mathrm{O}$ artigo VIII merece destaque porque nele foi estabelecido mecanismo de revisões periódicas do TNP, que ocorrem por meios das conferências de revisão realizadas a cada cinco anos. Esse mecanismo representa ferramenta muito importante quando se pensa no desarmamento nuclear como um ideal a ser buscado por meio de conquistas graduais. Como se verá um pouco mais à frente, a partir dele é que se tornaram propostas concretas os tratados de proibição completa de testes nucleares e o tratado que estabelece o corte na produção de combustíveis físseis, iniciativas muito importantes para complementar o TNP em sua função contra a proliferação nuclear.

O artigo IX, afora a definição do critério discriminatório do tratado ao descrever quem são os Estados aceitos como nuclearmente armados, ou seja, os que realizaram 
explosões nucleares até 01/01/1967, não merece destaque, referindo-se apenas às formalidades de adesão e ratificação, mas o art. X é muito importante porque nele se prevê o mecanismo de denúncia do tratado, por meio do qual um país se retira dele.

Especialmente a partir da experiência com a Coreia do Norte, nação que não teve dificuldades em denunciar o TNP, os Estados partes identificaram nesse artigo um dos pontos de fragilidade do regime de não proliferação, o que também será objeto de análise mais à frente.

$\mathrm{O}$ artigo $\mathrm{X}$ ainda deve ser lembrado pelo seu segundo item, que previu que no prazo de vinte e cinco anos após a entrada em vigor do tratado, seria convocada uma conferência para decidir sobre a continuidade da sua vigência, e por qual período. Os Estados nuclearmente armados pretendiam, nessa ocasião, que ocorresse extensão por período indefinido, o que somente foi obtido com a aceitação de medidas concretas exigidas pelos Estados não nucleares relacionadas ao cumprimento da obrigação assumida pelos Estados nucleares em relação ao seu próprio desarmamento.

Vê-se que tanto o item X.2, quanto o item VIII.3, constantes de um tratado criticado por refletir os interesses das nações mais poderosas, acabaram se tornando ferramentas muito importantes para a obtenção de avanços concretos no sentido do desarmamento nuclear.

Mesmo se tratando de uma norma que cria uma realidade desequilibrada e imperfeita, ainda assim permanece plenamente válida a proposição de que toda conquista nessa longa evolução construtiva em prol do desarmamento deve ser celebrada, para que um dia não seja mais utópico considerá-lo em termos efetivos.

Observadas as linhas gerais do tratado, é interessante compreender algumas das principais polêmicas que o cercam.

\subsection{Aspectos polêmicos do TNP}

\subsubsection{Descumprimento do Artigo VI - manutenção do viés discriminatório}

Como já foi antecipado no início deste capítulo, a principal polêmica que marca o TNP advém da distinção fundamental entre Estados nuclearmente armados e não 
nuclearmente $\operatorname{armados}^{24}$. Essa distinção, do ponto de vista da segurança nacional, representa um desafio de difícil entendimento, afinal, é difícil compreender o que motivaria os Estados a aceitar status desigual em relação ao direito à posse de armas nucleares ${ }^{25}$. Conforme observado, essa aceitação baseia-se numa barganha dupla, ou seja, a garantia de que a obrigação de não possuir armas nucleares não implicaria a renúncia ao uso pacífico da energia atômica, assim como da obrigação dos Estados nucleares de se desarmarem ${ }^{26}$. Especialmente nessa última parte é que têm sido observados grandes problemas, sendo eloquente que no artigo VI do tratado, em que se prevê essa obrigação, não haja uma previsão concreta de como ocorrerá o desarmamento, nem em quanto tempo.

Ao deixar a critério das potências nucleares a escolha do momento mais apropriado para a efetivação de tais medidas, caracteriza-se, mais uma vez, o objetivo do tratado de manter o status quo do impasse nuclear ${ }^{27}$. A perpetuação da relutância dos Estados nuclearmente armados de agirem de acordo com o artigo VI tem gerado, em todas as conferências de revisão do TNP, recriminação e críticas por parte dos demais países, sendo interessante notar que mesmo na década de 1980 esse problema já era considerado como central na dinâmica do TNP.

Zuckerman $^{28}$, em 1982, antevia que em "1985, quando o TNP seria submetido novamente à revisão quinquenal, os Estados não nuclearmente armados teriam total legitimidade para condenar as potências nucleares pela proliferação vertical em que eles deveriam ter se engajado ao longo dos 15 anos anteriores".

24 Uma das principais diferenças que podem ser notadas entre o TNP e a Convenção sobre as Armas Químicas é que esta não possui discriminação em suas bases, favorecendo maior eficácia do regime que procura estabelecer. Cf. THAKUR, Ramesh. Chemical weapons and the challenge of weapons of mass destruction. In: THAKUR, Ramesh; HARU, Ere (Orgs.). The Chemical Weapons Convention. Tokyo: United Nations University, 2006, p. 1.

25 LOUKA, Ellie. Nuclear Weapons, justice and the law. Cheltenham: Edward Elgar, 2011, p. 98. Cf. ZUCKERMAN, Solly. Nuclear Illusion and Reality. New York: The Viking, 1982, p. 133.

26 LOUKA, op. cit., p. 99. Podem ser mencionados, como fatores adicionais de incentivo à adesão, tanto a participação de Estados em alianças de segurança estratégica, quanto a avaliação dos custos de desenvolver e manter um programa nuclear para fins militares. , O programa nuclear americano teria consumido, entre 1948 e 2003, a cifra de US\$3,900,000,000,000 - três trilhões e novecentos bilhões de dólares (Cf. GINGER, Ann Fagan. Nuclear wepons are illegal - the historic opinion of the World Court and how it will be enforced. New York: The Apex, 1998, p. 468).

27 MAGALHÃES JÚNIOR, Japy Montenegro; MARQUES, Fernando Mário Rodrigues. A proliferação nuclear. Revista de Administração Pública, Rio de Janeiro, 12(4):173-197, out./dez.1978. Disponível em: <www.spell.org.br/documentos/download/15540>. Acesso em: 15 nov. 2014, p. 183.

28 ZUCKERMAN. op. cit. p. 133. 
Essa desigualdade entre "possuidores" e "não possuidores", mantida pela postura dos Estados nuclearmente armados, contraria princípios básicos em que está sedimentado o Direito Internacional. Acaba-se colocando em xeque, por exemplo, o princípio da igualdade das nações. Interessante a descrição de Ellie Louka a esse respeito:

Enquanto a Carta da ONU declara o princípio da igualdade, as regras, órgãos e procedimentos inseridos na Carta confirmam que se trata mais de uma ficção ou, idealisticamente, de um padrão a ser buscado do que de uma realidade cotidiana. [...] Todos os Estados deveriam ser autorizados a desenvolver seus armamentos, e os tratados internacionais deveriam ser aplicados uniformemente. Baseados no princípio da igualdade, todos os Estados deveriam possuir o direito de adquirir armas nucleares 29 .

Trata-se de demonstração crua da incongruência do conceito jurídico, não político, de soberania, que pressupõe uma igualdade jurídica que não se reflete na assimetria das relações de poder, principalmente em relação às grandes potências e seus poderios militar e econômico ${ }^{30}$. Ou, como resume Lafer, seria uma mostra da "tensão, nunca superada, entre a igualdade na teoria e a desigualdade de fato" ${ }^{31}$.

O fato é que a invenção das armas nucleares poderia ter sido o momento de afirmar abertamente um princípio da igualdade para que todos dispusessem daqueles meios de defesa. Não ocorreu desse modo, e perpetuou-se regime desigual, com políticas de defesa do séc. XXI reafirmando o caráter relevante das armas nucleares num futuro longo. $\mathrm{O}$ resultado disso é a corrosão do regime que o TNP tenta instituir, já que não é popular o discurso de que apenas a alguns Estados pode ser confiada a posse de armas nucleares, enquanto os demais são considerados perigosos, e párias, e irrevogavelmente propensos a uma destruição irracional ${ }^{32}$.

29 LOUKA, Ellie. Nuclear Weapons, justice and the law. Cheltenham: Edward Elgar, 2011, p. 203.

30 MORE, Rodrigo Fernandes. O Desarmamento no sistema de segurança coletiva da ONU. 2005. Tese (Doutorado) - Faculdade de Direito, Universidade de São Paulo, São Paulo, 2002, p. 17.

31 LAFER, Celso. Paradoxos e possibilidades. Rio de Janeiro: Nova Fronteira, 1982, p. 71.

32 CIMBALA, Stephen J. Nuclear weapons and Cooperative Security in the 21st Century - the new disorder. New York: Routledge, 2010, p. 56. 
Essa postura dúbia das nações nucleares acaba sendo recorrentemente utilizada para legitimar políticas de desenvolvimento de programas nucleares por outros países ${ }^{33}$.

Thakur reconhece que o estímulo mais poderoso para a proliferação nuclear é a continuidade da posse de armas nucleares por poucos Estados, para concluir que "enquanto for mantido o foco na não proliferação, e negligenciado o desarmamento, nenhum dos dois será obtido" ${ }^{34}$. Por isso é que, sem exagero algum, para que os esforços em prol da não proliferação sejam exitosos, se atribui às nações nucleares o papel fundamental de respeitarem os objetivos do controle 'vertical' de suas armas, ou seja, a redução dos tamanhos e capacidades de suas forças nucleares. Apenas com isso é que terão credibilidade para liderar os demais países a um controle 'horizontal' pela limitação da proliferação nuclear $^{35}$.

É interessante a ponderação feita por More ${ }^{36}$, que atenua, em termos, essa resistência das nações nucleares, destacando as dificuldades práticas para que possa haver desarmamento, uma vez que ele apenas ocorre "numa base de confiança moral e jurídica de que o outro lado vai de fato cumprir com as obrigações assumidas nos acordos, sejam elas vinculantes ou não". Ainda segundo o autor, "como o desarmamento se apoia sobre uma base muito frágil, de fácil e rápido rompimento, inclusive legal (os prazos de retirada dos tratados são relativamente curtos), desarmar-se pode ser uma opção estratégica que gera ainda mais insegurança e instabilidade, pois o equilíbrio de poder militar pode ser facilmente rompido e, nem sempre, reequilibrando a tempo". Essa pode ser considerada uma das razões adicionais para que se afirme que as potências nucleares remanescerão

33 ZUCKERMAN, Solly. Nuclear Illusion and Reality. New York: The Viking, 1982, p. 80. São inúmeras as referências nesse sentido. Cf. OTT, David H. Public International Law in the Modern World. Londres: Pitman, 1987, p. 328.

34 THAKUR, Ramesh. Has the good become the enemy of the best? In: BOULDEN, James; THAKUR, Ramesh Chandra; WEISS, Thomas George (Coords.). The United Nations and Nuclear Orders.Tokyo: United Nations University, 2009, p. 287-289, tradução livre do original em inglês.

35 CIMBALA, Stephen J. Nuclear weapons and Cooperative Security in the 21st Century - the new disorder. New York: Routledge, 2010, p. 6. Ver ainda: BUNDY, McGeorge; CROWE JR, William J.; DRELL, Sidney D. Reducing Nuclear Danger: The road away from the brink. New York: Council on foreign Relations Press, 1993, p.66., e REGEHR, Ernie. The Security Council and nuclear development. In: BOULDEN, James; THAKUR, Ramesh Chandra; WEISS, Thomas George (Coords.).The United Nations and Nuclear Orders. Tokyo: United Nations University, 2009, p. 38.

36 MORE, Rodrigo Fernandes. O Desarmamento no sistema de segurança coletiva da ONU. 2005. Tese (Doutorado) - Faculdade de Direito, Universidade de São Paulo, São Paulo, 2002, p. 53. 
como tais num futuro previsível ${ }^{37}$, em manifesto descumprimento da norma contida no art. VI do TNP.

Entretanto, "na ausência de uma autoridade central, com o cumprimento das regras cabendo aos próprios Estados, que podem recorrer a atos de autodefesa, inclusive atos de força, na defesa de seus direitos" ${ }^{38}$, especialmente quando o descumprimento de normas se refere à insistência na manutenção do próprio fundamento da enorme discrepância de poder militar em favor dos descumpridores, não se vislumbra uma saída viável, ao menos por ora.

Esse impasse, contudo, não invalida a norma, sendo importante lembrar que "exemplos de desrespeito existem em todos os sistemas legais. Com efeito, se houver absoluta conformidade entre a conduta real e a prescrita, pode-se dizer que a existência de regras não tem sentido, porque não é necessária" ${ }^{39}$.

A manutenção do viés discriminatório do TNP, com todos os seus efeitos negativos, não é, porém, o único aspecto polêmico que se coloca como um obstáculo para a plena consecução dos objetivos do tratado. As inconsistências das nações nuclearmente armadas colaboram para a consolidação de clima de falta de confiança, impedindo avanços concretos em prol do desarmamento, como será analisado a seguir.

\subsubsection{Inconsistências das potências nucleares como estímulo à proliferação}

Foram verificados acima os efeitos negativos decorrentes da relutância das potências nucleares em cumprirem a obrigação de se desarmarem, conforme previsto no art. VI, do TNP. Há, contudo, outros aspectos igualmente importantes no comportamento dos Estados nuclearmente armados que, do mesmo modo, desestruturam os fundamentos necessários para o bom funcionamento do regime de não proliferação e a busca do desarmamento nuclear.

Esse movimento ambíguo pode ser ilustrado pela mudança na conduta dos Estados antes e depois de adquirirem capacidade nuclear. Quando algum Estado que queira se

37 REGEHR, Ernie. The Security Council and nuclear development. In: BOULDEN, James; THAKUR, Ramesh Chandra; WEISS, Thomas George (Coords.). The United Nations and Nuclear Orders. Tokyo: United Nations University, 2009, p. 32.

38 BULL, Hedley. A sociedade anárquica. Tradução de Sérgio Bath. Brasília: UnB/IPRI, 2002, p. 86.

39 Ibidem. p. 157-158. 
firmar como potência nuclear é confrontado com restrições internacionais, a posição assumida tende a ser evasiva. Num momento imediatamente posterior, assim que adquire capacidade bélica nuclear, essa mesma nação passa a se posicionar a favor de um fortalecimento de mecanismos que impeçam ou dificultem que demais Estados também a adquiram.

É emblemática a postura da Índia, por exemplo, diante da iniciativa de se estabelecer uma proibição de produção de novos materiais físseis para fins explosivos. Como expõe Lafer $^{40}$, apenas depois de adquirir material suficiente para atender as suas pretensões militares, aquele país alinhou-se ao discurso em prol de uma proibição da continuidade de produção de combustíveis nucleares para fins não pacíficos.

Ainda pior, também como foi exposto pelo referido autor, durante o período de sua relutância, a Índia exigia que uma eventual proibição da produção de novos materiais físseis para fins bélicos fosse acompanhada de medidas concretas com vistas ao desarmamento nuclear, o que era rejeitado pelas potências nucleares de então.

Esse comportamento marcado pela dubiedade e inconsistência torna-se muito mais preocupante quando sinaliza claramente aos Estados não nucleares que, ao se manterem como tais, permanecem totalmente à mercê dos interesses das potências nucleares. Wight já afirmava que

a história pouco oferece para sustentar a asserção, defendida pelas grandes potências, de que elas são mais controladas e responsáveis do que as potências menores. Ao invés disso, a história sugere que as grandes potências desejam monopolizar o direito de criar conflitos internacionais ${ }^{41}$.

Esse viés comportamental, no que tange à questão nuclear, é especialmente deletério para o regime de não proliferação. Tomemos o recente exemplo ucraniano a título de ilustração ${ }^{42}$.

40 LAFER, Celso. Comércio, Desarmamento e Direitos Humanos - reflexões sobre uma experiência diplomática, 2. ed. São Paulo: Paz e Terra, 2006, p. 127-128.

41 WIGHT, M. A política do poder. Tradução de C. S. Duarte. Brasília: Editora Universidade de Brasília, 1985 , p. 32.

42 Não se irá, aqui, aprofundar a análise sobre o mérito da secessão da Crimeia e demais regiões ucranianas. 
Ao final da Guerra Fria, com a desestruturação da União Soviética, imediatamente surgiu um problema para a comunidade internacional representado pela ameaça de proliferação nuclear caso as ex-repúblicas soviéticas decidissem "nacionalizar" os arsenais atômicos alocados em seus territórios.

A Ucrânia era um desses países, que, caso se recusasse a devolver as armas nucleares para a Rússia, passaria a deter um dos principais arsenais atômicos do mundo. Um dos argumentos óbvios para que agisse assim era a proteção que seria propiciada por aquelas armas contra a Rússia, além da afirmação internacional que seria obtida pelo poderio nuclear recém assumido ${ }^{43}$.

Certamente, havia forte pressão internacional para que não agisse desse modo. Além disso, era previsível que, caso mantivesse as armas nucleares em sua posse, o resultado seria apenas a criação de novos custos e riscos, já que todos os vizinhos agiriam temerosamente, desencadeando uma corrida armamentista na região.

O país teria ainda de arcar com os elevados custos de manutenção e modernização do arsenal, que poderia não representar proteção contra a principal ameaça - a hostilidade russa $^{44}$.

Nesse contexto, a Ucrânia compreendeu que ameaças contra seu território não seriam externas e, depois de exigir garantias de segurança em relação à sua soberania e integridade territorial, abandonou as armas nucleares então em sua posse ${ }^{45}$.

Como consequência foi assinado o acordo de Budapeste ${ }^{46}$, entre os presidentes da Ucrânia, da Federação Russa, dos EUA e o primeiro ministro britânico, em contrapartida à adesão ucraniana ao TNP. O acordo formalizava as garantias de segurança acima mencionadas, sendo que os signatários assumiram a obrigação de evitar qualquer ameaça contra a independência política e a integridade do país.

43 BUNDY, McGeorge; CROWE JR, William J.; DRELL, Sidney D. Reducing Nuclear Danger: The road away from the brink. New York: Council on foreign Relations Press, 1993, p. 49.

44 Ibidem. p. 51.

45 LOUKA, Ellie. Nuclear Weapons, justice and the law. Cheltenham: Edward Elgar, 2011, p. 213.

46 BUDAPEST MEMORANDUMS ON SECURITY ASSURANCES, 1994. Publicado no site do Council on Foreign Relations (New York), seção Primary Sources, em 5 dez. 1994. Disponível em: http://www.cfr.org/arms-control-disarmament-and-nonproliferation/budapest-memorandums-securityassurances-1994/p32484. Acesso em: 5 dez. 2014. 
Os acontecimentos verificados especialmente ao longo de 2014, vinte anos depois, permitem avaliar se a decisão ucraniana de devolver o arsenal nuclear existente em seu território foi ou não acertada.

Ainda que seja difícil, senão impossível, afirmar qual seria a realidade presente caso fossem distintas as decisões políticas tomadas anos atrás, pode-se ao menos imaginar que a Rússia teria muito mais pudores para interferir nos assuntos internos da Ucrânia em relação à Crimeia e outras províncias que vêm flertando com iniciativas de separação do país.

Resumindo o sentimento de sua nação depois dessa sequência de acontecimentos, segue a fala, fundamental, do premiê interino da Ucrânia, Arseni Yatseniuk, que em 14 de março de 2014 alertou sobre a possibilidade da retomada de programa nuclear bélico do país, abandonado em 1994 com a assinatura do Acordo de Budapeste: "será difícil convencer quem quer que seja no mundo a não adquirir armas nucleares [...] a perda da Crimeia mina os esforços de não-proliferação" 47 .

Guardando as proporções, é possível afirmar que essa mesma dinâmica verificou-se em relação à Líbia, ou melhor, ao governo de Muammar Qadaffi.

Suspeitava-se das pretensões nucleares líbias, país que há décadas era considerado um pária devido ao apoio a atentados terroristas de larga escala internacional, como a explosão de um avião civil em Lockerbie, na Escócia, em 1988.

Em janeiro de 2004, um navio alemão, chamado BBC China, foi interceptado por agentes norte-americanos, quando foram encontradas peças para um programa de produção de armas nucleares na Líbia.

Com a revelação do programa até então secreto, e verificando as consequências desastrosas sofridas pelo regime de Saddam Hussein ${ }^{48}$, deposto e depois morto devido à mera suspeita de possuir armas atômicas, a Líbia em seguida renunciou às suas ambições

47 NETTO, Andei. Fracassa acordo entre Rússia e EUA; Moscou nega ação militar na Ucrânia. O Estado de São Paulo, 15 mar. 2014, A18.

48 Para uma descrição do temor do governo líbio em relação à experiência iraquiana, Cf. BANDEIRA, Luiz Alberto Moniz. A segunda guerra fria. Rio de Janeiro: Civilização Brasileira, 2013, p. 271. 
nucleares $^{49}$, e denunciou o Paquistão como o fornecedor do seu programa de armas nucleares ${ }^{50}$.

Menos de uma década depois, em meio à desestabilização regional ocasionada pelo movimento conhecido como "primavera árabe"51, a Líbia foi tomada por uma guerra civil.

Houve, então, uma coalizão internacional que apoiou os insurgentes contrários ao regime de Qadaffi, com intensos bombardeios que minaram a capacidade de manutenção do governo.

Na sequência, em outubro de 2011, o ex-ditador foi morto depois de linchamento público. Novamente não se irá aqui efetuar qualquer juízo de valor sobre o mérito da disputa interna verificada no país, nem se o ditador deveria ser deposto e submetido a sanções pelos crimes a ele imputados. O episódio é relevante para a presente análise apenas na medida em que novamente é possível ponderar qual teria sido a conduta internacional contra a Líbia caso esta possuísse armas nucleares. Segundo interessante relato de Moniz Bandeira ${ }^{52}$, baseado em notícias veiculadas a respeito,

tudo indica que nem os Estados Unidos nem a Grã-Bretanha nem a França deixaram de conspirar para destruir o regime de Gaddafi. Segundo Vijay Prashad, o colapso de Gaddafi enviou importante mensagem aos outros "rogue states"': seu maior erro foi renunciar ao programa nuclear.

É muito preocupante a constatação de que o maior erro de Qadaffi foi renunciar ao programa nuclear, a um só tempo reconhecendo-se que são vazias as garantias de segurança $^{53}$ prestadas pelas potências nucleares para que proliferadores aceitem se

49 LOPEZ, George A.; CORTIRIGHT, David. United Nations Sanctions and nuclear weapons. In: BOULDEN, James; THAKUR, Ramesh Chandra; WEISS, Thomas George (Coords.). The United Nations and Nuclear Orders. Tokyo: United Nations University, 2009, p. 121.

50 LANGEWIESCHE, William. O bazar atômico - a escalada do poderio nuclear. Tradução de J. Viegas. São Paulo: Cia das Letras, 2007, p. 82.

${ }^{51}$ Para breve contextualização das origens e principais características do movimento, ver DALLARI, Pedro Bohomoletz de Abreu. A experiência constitucional brasileira na transição árabe. Política Externa (USP), v. 21, n.1, p. 91-94, maio 2012. Disponível em: <http://politicaexterna.com.br/660/experienciaconstitucional-brasileira-transicao-arabe>. Acesso em: 30 nov. 2014.

52 PRASHAD, Vijay. Arab Spring, Lybian Winter. Edimburgo: AK Press, 2012, apud BANDEIRA, Luiz Alberto Moniz. A segunda guerra fria. Rio de Janeiro: Civilização Brasileira, 2013, p. 274.

53 Sobre a relevância das garantias de segurança para que proliferadores abandonem suas pretensões nucleares, Cf. BLIX, Hans. Questões sobre a Guerra do Iraque: o uso de força, armas de destruição em massa e as Nações Unidas. In: DUPAS, Gilberto; LAFER, Celso; SILVA, Carlos Eduardo Lins da (Orgs.). A nova configuração mundial do poder. São Paulo: Paz e Terra, 2008, p. 350. 
desarmar, e que, ao se desarmarem, estes fiquem sujeitos ao jogo de interesses dos mais poderosos.

Ao lado dos aspectos polêmicos decorrentes do comportamento dos Estados partes, devem-se ainda considerar os defeitos constantes da própria maneira como foi concebido e redigido o tratado. Como se verá a seguir, a elaboração do TNP abriu perigosa possibilidade para a existência de anomalias que não têm como receber tratamento pelo tratado, igualmente representando fragilidades que ameaçam o êxito do regime de não proliferação.

\subsubsection{Anomalias ameaçando a não proliferação}

Ainda que se tenha afirmado no início deste capítulo que as fragilidades do TNP foram intencionalmente nele inseridas por opção de seus idealizadores, há uma falha essencial no tratado cuja justificativa é de difícil compreensão.

No lugar de um critério que se propusesse a lidar com a discriminação de uma maneira minimamente coerente, o art. IX.3 já aqui observado definia a nação nuclear como "aquela que tenha fabricado e provado uma arma nuclear ou qualquer outro engenho nuclear explosivo antes de $1^{\circ}$ de janeiro de 1967".

Trata-se de uma definição cronológica de quais são as nações nucleares. O problema é que o critério não atende aos casos recentes de proliferação ${ }^{54}$.

As ameaças não estatais serão objeto de avaliação em tópico específico do trabalho, sendo importante, no momento, considerar as anomalias representadas por Estados que realizaram explosões nucleares depois da data fixada no TNP para que pudessem ser reconhecidas como nações nuclearmente armadas.

A conquista do poderio nuclear pela Índia, seguida pelo Paquistão, questionou o paradigma da não-proliferação e limitou a tendência de universalização do tratado, expondo uma grave limitação do regime por ele idealizado 55 .

54 THAKUR, Ramesh. The anomalies killing nonproliferation. In: War in our time - reflections on Iraq, terrorismo and weapons of mass destruction. Tokyo: United Nations University, 2007, p. 136-137.

55 LAFER, Celso. Comércio, Desarmamento e Direitos Humanos: reflexões sobre uma experiência diplomática. 2. ed. São Paulo: Paz e Terra, 2006, p. 123. 
Com efeito, nos moldes em que foi celebrado o TNP, ele é incapaz de absorver os países que desenvolveram capacidade nuclear militar depois de $1^{\circ}$ de janeiro de 1967 , expondo a debilidade do regime para o controle multilateral da proliferação nuclear. $\mathrm{O}$ dilema imposto por esses dois países, e por Israel, pode ser resumido assim: esses Estados não estão violando o TNP, porque nunca o adotaram; mas, simultaneamente, eles estão contestando a ordem internacional em que presumidamente existem apenas as cinco nações nuclearmente armadas reconhecidas pelo tratado ${ }^{56}$.

A situação torna-se ainda mais complexa quando se constata que, por não estarem formalmente violando qualquer regra, o Conselho de Segurança possui limitadíssima autoridade para desafiar qualquer desenvolvimento nuclear nesses países. Perde-se, assim, o elo estrutural necessário para viabilizar inspeções da AIEA, por meio das quais esta possa desempenhar seu papel de controle e monitoramento, e a aplicação de sanções caso constatada qualquer violação das regras do tratado ${ }^{57}$.

Geralmente, a ameaça representada pela posse de armas nucleares por Índia, Paquistão e Israel é atenuada pela identificação de que se destinam exclusivamente a um caráter defensivo ${ }^{58}$.

Há autores que chegam a afirmar que sejam quais forem as razões que os façam acreditar que necessitam de armas nucleares, não se trata de mera vaidade e menos ainda de qualquer indicação de ameaça agressiva contra esses países ${ }^{59}$. Essa leitura, contudo, é carregada de uma valoração subjetiva que pode ser plenamente contestada.

Para a Índia, por exemplo, aparentemente seu impulso para o desenvolvimento de armas nucleares tinha objetivos geopolíticos claros, tendo surgido "após a derrota humilhante sofrida para a China, bem como no primeiro teste de uma bomba atômica chinesa, realizado em 1964" 60 .

56 LOUKA, Ellie. Nuclear Weapons, justice and the law. Cheltenham: Edward Elgar, 2011, p. 155.

57 LOPEZ, George A.; CORTIRIGHT, David. United Nations Sanctions and nuclear weapons. In: BOULDEN, James; THAKUR, Ramesh Chandra; WEISS, Thomas George (Coords.). The United Nations and Nuclear Orders. Tokyo: United Nations University, 2009, p. 125.

58 BUNDY, McGeorge; CROWE JR, William J.; DRELL, Sidney D. Reducing Nuclear Danger: The road away from the brink. New York: Council on foreign Relations Press, 1993, p. 70.

59 Ibidem, p. 70-71.

${ }^{60}$ LANGEWIESCHE, William. O bazar atômico - a escalada do poderio nuclear. Tradução de J. Viegas. São Paulo: Cia. das Letras, 2007, p. 95-96. 
Essa iniciativa, por sua vez, também gerou desestabilização regional, havendo incitado o Paquistão a rumar pelo mesmo caminho, já que seus protestos contra a iniciativa indiana não repercutiram de maneira concreta, sendo digno de nota que nenhuma sanção foi imposta contra a Índia ${ }^{61}$.

Essa desestabilização facilmente extrapolaria a região para influir

em outra zona de tensão: o Oriente Médio. O recente teste pelo Irã de míssil de longo alcance passa a ser visto nesse novo contexto, e influi também nos cálculos de risco de Israel, uma vez que sua alçada de voo incluiria Tel Aviv, e sem dúvida nos da Turquia, rival regional do Irã na projeção de influencia no ex-império soviético da Ásia Central ${ }^{62}$.

Ainda que considerado o caráter exclusivamente defensivo dos arsenais atômicos indianos e paquistaneses, o efeito desestabilizador em cascata no regime da não proliferação não é desprezível.

Do mesmo modo, não se pode ignorar a polêmica decorrente da iniciativa nuclear israelense. No caso, há uma peculiaridade adicional, já que, até hoje, a postura de Israel é marcada por ambiguidade, nunca tendo sido afirmada a posse de armas nucleares por aquele país. Há relatos de que a então primeira ministra de Israel, Golda Meir, em uma reunião secreta,

ao admitir finalmente a capacidade nuclear israelense, teria prometido que Israel não declararia seu status nuclear, não testaria seus armamentos e não os usaria para ganhos diplomáticos ou territoriais; a bomba israelense seria mantida para utilização apenas em caso de última necessidade ${ }^{63}$.

Essa política tende a abrandar o temor explícito dos vizinhos e o ambiente político de seus aliados, em especial os EUA, que não são confrontados abertamente sobre o tema.

61 LANGEWIESCHE, William. O bazar atômico - a escalada do poderio nuclear. Tradução de J. Viegas. São Paulo: Cia das Letras, 2007, p. 82.

62 LAFER, Celso. Comércio, Desarmamento e Direitos Humanos: reflexões sobre uma experiência diplomática. 2. ed. São Paulo: Paz e Terra, 2006, p. 131.

63 SAMPAIO, Maria Feliciana Nunes Ortigão de. O Tratado de Proibição Completa dos Testes Nucleares $(C T B T)$ : Perspectivas para sua entrada em vigor e para a atuação diplomática brasileira. Brasília: Alexandre de Gusmão, 2012, p. 141. 
Tal ambiguidade do discurso é calcada no argumento do poder de dissuasão: a vagueza previne qualquer defesa pública do programa nuclear israelense e permite o argumento de que nenhum Estado ou grupo deve temer eventual arma nuclear de Israel a não ser que tente destruir o país ${ }^{64}$.

Apesar desses aspectos, e da enorme diferença que existe, por exemplo, em relação à investida nuclear iraniana, cujos líderes costumam discursar abertamente sobre o objetivo de "varrer Israel do mapa", não se pode ignorar que, para diversos rivais regionais, a posse de armas nucleares por Israel, mesmo nunca confessada, representa ameaça intolerável contra a estabilidade do Oriente Médio.

Prova disso ocorreu em 2008, quando os países que integram a Liga Árabe instaram Israel a admitir a posse de armas nucleares, solicitando ao Conselho de Segurança que pressionasse o país para que destruísse seu arsenal e submetesse suas instalações atômicas à inspeção internacional. Caso não fosse cumprida essa meta, os países árabes se retirariam do TNP e permaneceriam assim até que Israel aderisse ao tratado ${ }^{65}$.

É compreensível essa reação da Liga Árabe, já que, contrariamente, a mera possibilidade de armas nucleares na Síria ou no Irã é considerada uma questão urgente para os estrategistas militares de Israel ${ }^{66}$.

De todo modo, para superar essas incertezas e vaguezas, assim como o limbo jurídico da situação nuclear do subcontinente indiano, é que se advoga a necessidade de se lidar abertamente com esses três países considerando o que de fato são, propiciando franqueza muito mais salutar para o fortalecimento do regime de não proliferação ${ }^{67}$.

Existem algumas propostas para se viabilizar a superação dessa anomalia, tais como a tentativa de inserir os países no regime multilateral de modo gradativo, para, em longo prazo, aderirem ao TNP; a aprovação de resoluções pela Assembleia Geral para pressioná-

64 BUNDY, Mcgeorge; CROWE Jr.,William J.; DRELL, Sidney D. Reducing Nuclear Danger - The road away from the brink. New York: Council on foreign Relations Press, 1993, p. 69.

65 ARAB league vows to drop out of npt if Israel admits it has nuclear weapons. Haaretz, Israel, Mar. 5, 2008. Disponível em: http://www.haaretz.com/news/arab-league-vows-to-drop-out-of-npt-if-israeladmits-it-has-nuclear-weapons-1.240728. Acesso em: 20 nov. 2014.

66 CIMBALA, Stephen J. Nuclear weapons and Cooperative Security in the 21st Century - the new disorder. New York: Routledge, 2010, p. 54.

67 BUNDY, McGeorge; CROWE JR, William J.; DRELL, Sidney op. cit., p. 70. Tradução livre do original: "Não há sentido em se propor uma zona livre de armas nucleares no Oriente Médio omitindo-se a existência de ogivas nucleares israelenses". 
los; o estabelecimento de iniciativas não institucionais, com negociações paralelas para determinar a restrição de condutas que determinem o alinhamento aos objetivos da não proliferação ${ }^{68}$.

Contudo, o fato é que enquanto perdurar a situação atual, esses três Estados constituirão uma sombra que paira contra o regime estabelecido pelo TNP. Há pouco tempo, aliás, essa sombra parece ter sido ampliada depois do anúncio de um acordo bilateral de cooperação nuclear entre EUA e Índia.

Em declaração conjunta de 18 de julho de 2005 do primeiro-ministro indiano e do presidente norte-americano, acabou sendo legitimado o status nuclear indiano uma vez que o acordo apenas se referiu às instalações nucleares civis para serem inseridas no regime de controle e verificação de não proliferação. Não houve qualquer menção às instalações nucleares militares indianas, precedente perigoso, porque o acordo de cooperação, ao assumir essas circunstâncias, legitimou o status nuclear daquele país, e pode incentivar outros Estados a agirem do mesmo modo e aguardar pelo seu reconhecimento, ainda que décadas depois de adquirirem capacidade nuclear bélica. Uma vez que o TNP admite a existência de instalações nucleares bélicas apenas para os cinco países reconhecidos pelo tratado como nuclearmente armados, a aceitação, pelos EUA, da Índia como um parceiro nuclear acaba minando o regime do TNP, estimulando outros Estados a andarem pela mesma trilha ${ }^{69}$.

É interessante notar com esse exemplo que a questão nuclear é também problematizada por ser tratada de modo inconsistente, sujeitando-se a conjunturas políticas e agendas individuais de determinados Estados que acabam minando os objetivos de não proliferação e do desarmamento nuclear. Nesse sentido, o acordo bilateral de 2005 foi incentivado, em grande parte, pelos interesses comerciais dos EUA em relação à Índia.

Essa sujeição das metas da não proliferação a interesses políticos egoísticos já havia, anos antes, causado efeitos negativos naquela mesma região, sendo identificados como

68 SIDHU, Waheguru Pal Singh. Dealing with extra- npt actors and non-state actors. In: BOULDEN, James; THAKUR, Ramesh Chandra; WEISS, Thomas George (Coords.). The United Nations and Nuclear Orders. Tokyo: United Nations University, 2009, p. 219-222.

69 THAKUR, Ramesh. India's nukes pose paradox in War in our time - reflections on Iraq, terrorism and weapons of mass destruction. Tokyo: United Nations University, 2007, p. 100. 
causa da motivação do Paquistão para desenvolver seu programa nuclear clandestino. Com efeito,

\begin{abstract}
legalmente, os EUA deveriam impor sanções quando a Índia, seguida pelo Paquistão, testaram armas nucleares em 1998. Os esforços para aplicá-las foram suavizados e tiveram vida curta, entretanto. Eles conflitaram com outros interesses políticos norte-americanos, incluindo crescente engajamento comercial com a Índia e a continuidade da parceria estratégica com o Paquistão [...] o principal aliado na investida para sobrepujar o regime do Taleban no Afeganistão e continuar a luta contra a Al Qaeda ${ }^{70}$.
\end{abstract}

Ao lado da anomalia representada pela existência dos arsenais atômicos desses três países, há, atualmente, novas ameaças de proliferadores, sendo a postura da Coreia do Norte e do Irã os exemplos mais candentes. Essas questões serão analisadas na última parte desta dissertação, quando serão avaliadas ameaças atuais contra a não proliferação e o ideal do desarmamento nuclear.

Como foi antecipado, o regime estabelecido pelo TNP é marcado por diversas imperfeições. Ainda assim, o papel desempenhado pelo tratado é de extrema relevância para se evitar a proliferação nuclear e, paralelamente, encetar esforços concretos na busca do desarmamento nuclear mundial.

A própria existência de apenas quatro países que adquiriram armas nucleares desde que o TNP entrou em vigor não deixa de ser um fator bastante significativo de seu êxito. Além disso, o tratado serviu de base para que surgissem novas iniciativas no regime de não proliferação e desarmamento nuclear.

\title{
2.4 Avanços propiciados pelo TNP
}

Foi antecipado na descrição das provisões do TNP que o mecanismo de revisões periódicas estabelecido no artigo VIII representou importantíssima ferramenta de construção e reforço do regime da não proliferação e da luta pelo desarmamento nuclear.

70 LOPEZ, George A.; CORTIRIGHT, David. United Nations Sanctions and nuclear weapons. In: BOULDEN, James; THAKUR, Ramesh Chandra; WEISS, Thomas George (Coords.). The United Nations and Nuclear Orders. Tokyo: United Nations University, 2009, p. 126-127. 
As Conferências de Revisão do TNP, neste particular, revelaram-se um importante meio de se obterem interpretações vinculantes do tratado, já que, de acordo com o Direito Internacional, "todo acordo subsequente com relação à interpretação de um tratado ou à aplicação de suas provisões" deve ser levado em conta em sua aplicação ${ }^{71}$.

Uma vez que a grande maioria dos Estados partes se ressentia do viés discriminatório do tratado e da resistência das potências nucleares contra a obrigação de se desarmarem, as conferências de revisão realizadas a cada cinco anos eram marcadas pela pressão, cada vez mais significativa, a favor do fortalecimento do regime estabelecido pelo TNP.

A quinta conferência, realizada em 1995, marcou também a conferência prevista no art. X, que decidiria sobre a extensão da vigência do tratado. As nações nucleares pretendiam, como já se viu, que fosse aprovada a extensão por prazo indefinido, enquanto os demais países necessitavam de maiores demonstrações no sentido do desarmamento nuclear para que apoiassem aquele interesse.

A partir dessa ocasião foi que se notou maior mobilização e aumento do poder de pressão dos Estados não nucleares para obterem das potências nucleares sinais mais claros contra o comportamento inconsistente e dúbio descrito nos tópicos anteriores do presente capítulo.

Em relação ao próprio TNP, naquela conferência foi aprovada decisão pela qual se tornou mais frequente e se reforçou o mecanismo de revisão do tratado, dando margem a que os países não-nucleares exercessem, também no âmbito do TNP, maior pressão política em favor do desarmamento nuclear. ${ }^{72}$

Essa significativa mudança é considerada como um dos fatores que incentivou, por exemplo, a adesão do Brasil ao TNP.

Ao lado dessa alteração no âmbito interno do tratado, foi reforçada a luta pelo desarmamento, tendo sido obtidos compromissos das potências nucleares em relação a outras iniciativas muito importantes para reforçar o regime de não proliferação e a luta pelo desarmamento nuclear, como o CTBT - Tratado de Proibição Geral de Testes Nucleares, e

71 DAMROSCH, Lori Fisler. Codification and legal issues. In: BOULDEN, James; THAKUR, Ramesh Chandra; WEISS, Thomas George (Coords.). The United Nations and Nuclear Orders. Tokyo: United Nations University, 2009, p.180.

72 LAFER, Celso. Comércio, Desarmamento e Direitos Humanos: reflexões sobre uma experiência diplomática. 2. ed. São Paulo: Paz e Terra, 2006, p. 101. 
o FMCT, que determina o corte na produção de novos combustíveis físseis para fins militares $^{73}$.

Os tratados não serão analisados em detalhes neste momento, sendo relevante se ater à constatação de que, para a aprovação da extensão da vigência do TNP indefinidamente, eles foram o objeto da barganha obtida pelos Estados não nucleares: o "CTBT foi, portanto, o principal elemento de barganha exigido pelos Estados não nuclearmente armados em troca da extensão indefinida da validade do TNP."74

Infelizmente, logo após a conferência realizada em 1995,

a França e a China reiniciaram e aceleraram seus programas de testes nucleares antes do final da negociação do CTBT - suspeita-se que para calibrar seus instrumentos a fim de permitir futuros testes simulados por computador, bem como para garantir maior confiabilidade e desenvolver artefatos mais compactos ${ }^{75}$.

Tratava-se, novamente, de mostras da conduta dúbia criticada mais acima.

Apesar disso, é possível constatar que a partir do TNP, ele próprio imperfeito, mas importante para a finalidade do desarmamento nuclear, foram sendo aprimorados os elementos do regime internacional existentes para essa finalidade.

Verifica-se, claramente, a confirmação da construção gradativa na busca do ideal do desarmamento, mesmo com frustrações e em ritmo mais vagaroso do que o desejado.

Confirmando essa percepção, a Conferência de Revisão do TNP realizada na sequência, em 2000, foi de enorme relevância ao estabelecer treze passos concretos em relação ao desarmamento nuclear:

1. A urgência na entrada em vigor do CTBT.

2. Uma moratória na realização de qualquer explosão nuclear até que o CTBT entre em vigor.

73 BLIX, Hans. Questões sobre a Guerra do Iraque: o uso de força, armas de destruição em massa e as Nações Unidas. In: DUPAS, Gilberto; LAFER, Celso; SILVA, Carlos Eduardo Lins da (Orgs.). A nova configuração mundial do poder. São Paulo: Paz e Terra, 2008, p. 340.

74 SAMPAIO, Maria Feliciana Nunes Ortigão de. O Tratado de Proibição Completa dos Testes Nucleares $(C T B T)$ : Perspectivas para sua entrada em vigor e para a atuação diplomática brasileira. Brasília: Alexandre de Gusmão, 2012, p. 27.

75 Ibidem, p. 78. 
3. A necessidade de se negociar um tratado não discriminatório proibindo a produção de materiais físseis para armas nucleares.

4. A necessidade de se instituir um organismo com mandato específico para lidar com o desarmamento nuclear.

5. O princípio da irreversibilidade a ser aplicado no desarmamento nuclear e aprimoramento de medidas de redução e controle de armamentos.

6. Um compromisso inequívoco das nações nucleares de eliminarem completamente seus arsenais atômicos.

7. A urgente entrada em vigor do START II e a conclusão do START III assim que possível, mantendo a força do Tratado anti-mísseis balísticos.

8. A implementação da iniciativa trilateral entre EUA, Rússia e AIEA.

9. Liderança das nações nucleares para promoverem desarmamento nuclear e estabilidade internacional.

10. Acordos para submeterem os combustíveis físseis que possuam a inspeções da AIEA, direcionando-os para fins pacíficos.

11. Reafirmação de que o objetivo final é o completo desarmamento nuclear sob um controle internacional efetivo.

12. Estabelecimento de relatórios regulares sobre o cumprimento da obrigação de desarmamento, com base na opinião consultiva da Corte Internacional de Justiça de julho de 1996 sobre a legalidade do uso ou ameaça de uso das armas nucleares.

13. O desenvolvimento mais profundo de capacidades de verificação necessárias para assegurar cumprimento efetivo das obrigações relacionadas ao desarmamento nuclear, e à manutenção de um mundo livre de armas nucleares. ${ }^{76}$

Diante dessas conquistas, mesmo com suas imperfeições é plenamente possível considerar o TNP como um sucesso, já que a grande maioria dos Estados partes não demonstraram interesse em obterem armas nucleares, ainda que não seja possível desconsiderar outras possíveis causas para o baixo volume de proliferadores, tais como a incapacidade financeira de arcarem com programas de armas nucleares e avaliações geopolíticas que dispensam a necessidade de adquiri-las ${ }^{77}$.

Seja o que for, o TNP segue mantendo uma aura equivalente a um aspecto quase sagrado. Qualquer abalo contra ela desperta grandes temores em relação a uma proliferação desenfreada ${ }^{78}$.

76 Disponível em: <http://www.un.org/disarmament/WMD/Nuclear/pdf/finaldocs/2000\%20-\%20NY\% 20\%20NPT\%20Review\%20Conference\%20-\%20Final\%20Document\%20Parts\%20I\%20and \%20II.pdf $>$. Acesso em: 7 Dez. 2014.

77 LOUKA, Ellie. Cheltenham: Edward Elgar, 2011, p. 102.

78 Ibidem, p. 155. 
Por isso é que se considera tão importante a contenção da proliferação pelo Irã, e a reversão das capacidades nucleares norte-coreanas, tidas como testes significativos para a efetividade do regime de não proliferação ${ }^{79}$.

79 CIMBALA, Stephen J. Nuclear weapons and Cooperative Security in the 21st Century - the new disorder. New York: Routledge, 2010, p. 28. 


\section{OS DOIS OUTROS PILARES -}

\section{A AIEA E O CONSELHO DE SEGURANÇA DA ONU}

Como foi visto, o TNP possui papel central no regime de não proliferação e na proposição de um desarmamento nuclear, estabelecendo as principais obrigações para evitar o espraiamento dos arsenais atômicos a novos Estados, e meios para pressionar as nações nuclearmente armadas a adotarem medidas em prol do abandono dos já existentes.

Mas, isoladamente, o tratado não é capaz de desempenhar as funções que dele se esperam em prol desses objetivos. Para sua operacionalidade, ele se apoia de maneira essencial sobre o sistema de salvaguardas estabelecido pela Agência Internacional de Energia Atômica (AIEA) ${ }^{1}$.

Uma vez que o tratado foi celebrado uma década depois da instituição da AIEA, ele próprio faz referência às funções de monitoramento e verificação exercidas pela agência, conforme previsto em seu art. III $^{2}$, que estabelece a obrigação para todos os Estados não nucleares ${ }^{3}$ partes do tratado de aceitarem medidas de verificação estabelecidas em acordos com a AIEA, cuja finalidade é supervisionar "o cumprimento das obrigações assumidas de acordo com o tratado destinadas a impedir o desvio da energia nuclear de fins pacíficos para as armas nucleares ou outros engenhos nucleares explosivos".

Mas, como o TNP não estabeleceu nenhum órgão administrativo central nem um secretariado para coordenar suas realizações e fiscalizar seu cumprimento, sua efetividade apenas se torna possível com o apoio do Conselho de Segurança da ONU, órgão ao qual se recorre para a aplicação de sanções quando se identifica descumprimento das obrigações assumidas no tratado, ou mera suspeita de violações.

Estabelece-se, assim, uma relação de complementariedade. Enquanto o regime calcado na correlação TNP-AIEA desobriga o Conselho da impossível tarefa de uma gestão detalhista da política nuclear, este alivia o regime da impossível missão de submeter um caso específico de violação ou ameaça de proliferação ao escrutínio global, exercendo

MURPHY, John F. Force and Arms. In: SCHACHTER, Oscar; JOYNER, Christopher. C. (Eds.). United Nations Legal Order. Cambridge: American Society of International Law, 1995, p. 310. v. 1.

2 RANGEL, Vicente Marotta. Direito e relações internacionais. 7. ed. São Paulo: RT, 2002, p. 226-227.

3 Também essa obrigação, imposta apenas aos Estados não nucleares, é vista como uma faceta discriminatória do TNP. 
o papel de último garantidor da integridade do regime. A autoridade do Conselho tem ainda o importante efeito de reforçar o poder da AIEA perante determinado Estado inspecionado, e acaba autorizando-a a usar métodos mais rígidos de verificação ${ }^{4}$.

Por essas razões é que se considera o Conselho de Segurança o tutor da não proliferação, exercendo relevante papel de autoridade para gerir o regime instituído pelo TNP de modo que sejam minimamente respeitadas as obrigações internacionais estabelecidas para evitar o espraiamento de armas nucleares ${ }^{5}$.

No presente capítulo serão analisados, então, esses dois pilares que, em conjunto com o TNP, conformam a estrutura central do regime de não proliferação, a AIEA e a atuação do Conselho de Segurança da ONU em relação à questão nuclear.

\subsection{AIEA - Características e funções}

Como já foi visto em capítulos anteriores, a gênese da AIEA remonta ao discurso “átomos pela paz”, proferido pelo presidente norte-americano Eisenhower, perante a Assembleia Geral das Nações Unidas, em 8 de dezembro de 1953. As ideias contidas no discurso acabaram formando o embrião do projeto que, quatro anos depois, conformaram o Estatuto da AIEA, instituída oficialmente em 1957.

Diferentemente da proposta original apresentada por Eisenhower, a AIEA não chegou a se constituir como uma autoridade mundial com o monopólio do controle dos combustíveis nucleares, restringindo-se a exercer o papel de fiscalizadora dos programas nucleares para fins pacíficos, tanto observando aspectos de segurança quanto atentando para eventuais desvios de combustíveis e instalações com fins militares. Seu estatuto ${ }^{6}$,

4 MÜLLER, Harald. Verification and Compliance. In: BOULDEN, James; THAKUR, Ramesh Chandra; WEISS, Thomas George (Coords.). The United Nations and Nuclear Orders. Tokyo: United Nations University, 2009, p. 160.

5 REGEHR, Ernie. The Security Council and Nuclear Disarmament. In: BOULDEN, James; THAKUR, Ramesh Chandra; WEISS, Thomas George (Coords.). The United Nations and Nuclear Orders. Tokyo: United Nations University, 2009, p. 43.

6 IAEA. The statute of the IAEA. Disponível em: <http://www.iaea.org/about/statute\#a1-12>. Acesso em: 29 nov. 2014. 
como foi resumido por Fischer ${ }^{7}$, define os três pilares de sua atuação - verificação nuclear e segurança, proteção e transferência de tecnologia.

Segundo o texto definido pela própria $\mathrm{AIEA}^{8}$, trata-se de uma organização independente, intergovernamental, baseada em ciência e tecnologia, submetida ao sistema da ONU, que se presta ao interesse global de cooperação nuclear.

Ainda segundo a própria agência, sua missão é auxiliar estados membros a planejarem o uso de energia nuclear para diversos fins pacíficos, facilitando a transferência de tecnologia de um modo sustentável para o desenvolvimento dos estados membros; desenvolver padrões de segurança nuclear e promover sua implementação e manutenção para a proteção da saúde humana e do meio-ambiente contra a contaminação por radiação; e verificar por meio de inspeções o cumprimento das obrigações assumidas pelos estados membros, sob o regime do TNP ou de outros acordos de não proliferação, sobre o uso da energia nuclear apenas para fins pacíficos.

Sua estrutura básica, sem contar o quadro de funcionários responsáveis pelo exercício do papel de fiscalização e elaboração de avaliações técnico-científicas, baseia-se numa conferência geral, integrada por todos os estados membros, e pelo conselho de governos, seu principal corpo diretivo. Enquanto a conferência é composta por todos os estados membros, o conselho é composto apenas por 35 membros eleitos periodicamente, sendo que 13 são praticamente permanentes, de acordo com critério baseado na identificação dos estados detentores das mais avançadas tecnologias de energia atômica.

Essa característica permite a crítica de que a AIEA não é democrática ${ }^{9}$, já que os Estados mais avançados nessa área são justamente aqueles que também são privilegiados no regime do TNP. Essa sujeição aos interesses políticos das principais nações nucleares constitui uma fragilidade que compromete o respeito universal pela autoridade da agência, já que diversos países não alinhados resistem a inspeções exatamente com base em argumentos políticos, como será observado um pouco mais à frente.

7 FISCHER, David. History of the International Atomic Energy Agency: the First Forty Years. Vienna: The Agency, 1997. Disponível em: <http://www-pub.iaea.org/MTCD/publications/PDF/ Pub1032_web.pdf〉. Acesso em: 30 jun. 2013.

8 IAEA. The IAEA Mission Statement. Disponível em: 〈http://www.iaea.org/about/mission>. Acesso em: 30 nov. 2014.

9 SOARES, Guido Fernando Silva. As salvaguardas nos acordos nucleares. São Paulo: Bushatsky, 1977 , p. 36 . 
As dificuldades impostas por aspectos políticos para o desempenho de suas funções são inerentes ao tema com que a AIEA lida, já que programas nucleares são sempre estratégicos para o desenvolvimento de qualquer nação, representando significativa matriz energética associada ao incremento econômico-industrial. Esse desenvolvimento, contudo, pode ser perigoso para o regime de não proliferação caso sucumba a "a algum tipo de 'ideologia nuclear' movida por anseios de acelerar artificialmente a incorporação de um país ao concerto das grandes potências" ${ }^{10}$.

Soares, neste particular, há décadas já avaliava com precisão que

a geração de energia, assunto interno, interliga-se com a obtenção de combustível nuclear, cuja implicação diz respeito ao mercado internacional e à política de evitar o espraiamento das armas nucleares, assunto tipicamente da política exterior dos Estados ${ }^{11}$.

Nessa medida é que se insere o principal meio de atuação da AIEA, de acordo com a identificação de que o direito ao desenvolvimento de energia nuclear não é irrestrito, mas condicionado ao princípio da não proliferação e às salvaguardas necessárias para assegurar seu exclusivo uso pacífico ${ }^{12}$.

É muito importante esse papel porque a experiência já deu mostras suficientes de que quando um Estado deseja desenvolver armas nucleares, ele será capaz disso a não ser que suas atividades sejam monitoradas, mesmo que contrariando eventuais discursos que exaltem soberania e interesses nacionais ${ }^{13}$.

Sobre a facilidade que um Estado teria para desviar capacidade nuclear civil para fins militares, observe-se a descrição abaixo dada por Soares. Considerando que esses dados referem-se à década de 1970, é possível imaginar que atualmente esse desvio seria ainda mais fácil pelo avanço tecnológico verificado ao longo do tempo:

10 PADILHA, Tarcisio Meirelles. Energia nuclear em questão. 2. ed. Rio de Janeiro: Instituto Euvaldo Lodi, 1981, p. X.

11 SOARES, Guido Fernando Silva. As salvaguardas nos acordos nucleares. São Paulo: Bushatsky, 1977 , p. 19.

12 LOUKA, Ellie. Nuclear Weapons, Justice and the Law. Cheltenham: Edward Elgar, 2011, p. 99.

13 Ibidem, p. 101. 
um país que tenha a capacidade de produzir $150.000 \mathrm{~kW}$, a partir de um reator nuclear (e tal capacidade de há muito foi superada na rede comercial; Angra I, a exemplo, produzirá $1.626 .000 \mathrm{~kW}$ elétricos), funcionando a $20 \%$ de seu rendimento, ao cabo de 10 dias, produzindo 8/10 de plutônio para cada átomo de U-235, terá a quantidade de plutônio necessário para uma bomba do tamanho da que foi lançada em Nagasaki. ${ }^{14}$

As atividades da AIEA tentam impedir esse desvirtuamento. $\mathrm{O}$ artigo $\mathrm{XII}^{15}$ resume as ações a serem por ela desempenhadas nessa função:

1. examinar os Projetos de equipamentos e instalações, inclusive reatores nucleares, para aprová-los caso se comprove que não se prestam a fins militares, e que estejam de acordo com padrões de segurança e saúde, e que permitam a aplicação de salvaguardas;

2. impor que sejam respeitadas medidas de segurança e saúde determinadas pela agência;

3. solicitar registros de operação e manutenção para a fiscalização da quantidade dos combustíveis físseis utilizados ou produzidos no projeto;

4. solicitar e receber relatórios periodicamente;

5. aprovar meios de reprocessamento do material irradiado para assegurar que não ocorra desvio para fins militares, e que atendam a padrões de segurança e saúde;

6. enviar inspetores designados pela agência depois de consultas com os países a serem inspecionados, que deverão assegurar acesso em qualquer tempo a todas as instalações submetidas ao acordo de salvaguardas, considerados necessários para a fiscalização do combustível físsil utilizado no programa nuclear.

7. em caso de descumprimento por algum Estado, a agência poderá suspender ou extinguir toda cooperação nuclear estabelecida com o estado violador.

É muito importante a previsão final do artigo, estipulando que, em caso de descumprimento, deverá ser enviado um relatório ao Diretor Geral da agência, que o

14 SOARES, Guido Fernando Silva. As salvaguardas nos acordos nucleares. São Paulo: Bushatsky, 1977, p. 23-25.

15 IAEA. The statute of the IAEA. Disponível em: <http://www.iaea.org/about/statute\#a1-12>. Acesso em: 29 nov. 2014. Tradução livre do autor. 
submeterá ao Conselho de Governos. Este, por sua vez, caso mantida a violação por algum Estado membro, deve denunciar a situação ao Conselho de Segurança da ONU. Nessa hipótese, além das punições como suspensão de relações de cooperação estabelecidas com a agência, abre-se caminho para a aplicação de severas sanções a serem aplicadas para se exigir o abandono de práticas condenadas pelo regime de não proliferação.

Neste particular, é curioso notar que a agência, muitas vezes, apenas consegue obter uma constatação de violações ex post facto. Isso porque a frequência das inspeções é determinada de acordo com o tempo estimado de conversão de combustíveis nucleares até a quantidade suficiente para a obtenção de uma arma nuclear. Desse modo, realisticamente, como nem sempre esse período de conversão coincide com a periodicidade das inspeções, estas conseguem apenas identificar violações já cometidas, possibilitando somente o alerta de que algum país já possui um dispositivo atômico ilegalmente obtido ${ }^{16}$, e não que esteja em vias de obtê-lo.

A função dessas inspeções, além de monitorar o cumprimento das obrigações estabelecidas nos acordos de salvaguardas previstos no $\mathrm{TNP}^{17}$, é assegurar aos demais Estados a certeza sobre o cumprimento das regras ${ }^{18}$.

Deve ainda ser destacada a previsão de que os acordos de salvaguarda não se restringem apenas a Estados, podendo ser também estabelecidos com organismos multilaterais como as zonas livres de armas nucleares, que serão analisadas no próximo capítulo, ou inseridos em acordos regionais ou mesmo bilaterais de cooperação nuclear para fins civis ${ }^{19}$.

É significativo citar, por exemplo, o acordo mantido entre a AIEA e a EURATOM, estabelecido em $1973^{20}$, que constitui a principal e mais bem estruturada iniciativa internacional de cooperação para uso de energia nuclear. A EURATOM, ou Comunidade

16 LOUKA, Ellie. Nuclear Weapons, Justice and the Law. Cheltenham: Edward Elgar, 2011, p. 115-116.

17 Atualmente, 147 países possuem acordos de salvaguarda, sendo que 23 não ainda em vigor. Cf. IAEA. Additional Protocols. Disponível em: <http://www.iaea.org/safeguards/documents/AP_status_list.pdf>. Acesso em: 9 dez. 2014.

18 MÜLLER, Harald. Verification and Compliance. In: BOULDEN, James; THAKUR, Ramesh Chandra; WEISS, Thomas George (Coords.). The United Nations and Nuclear Orders. Tokyo: United Nations University, 2009, p. 154.

19 LOUKA, op. cit., p. 268.

20 EUROPEAN COMMUNITY. News Release. Entry into force of Euraton - IAEA Agreement. 17 Feb. 1977. Disponível em: <http://aei.pitt.edu/53692/1/NR_(77)_4.pdf>. Acesso em: 12 dez. 2014. 
de Energia Atômica Europeia ${ }^{21}$, possui um nível de elaboração institucional muito mais aprimorado do que o do regime da não proliferação instituído pelo TNP, sendo inclusive considerado que se o sistema europeu fosse espraiado mundialmente, haveria uma revolução desse regime ${ }^{22}$.

Basicamente, a comunidade europeia diferencia-se por possuir uma central de monitoramento que controla o suprimento de material nuclear, garante suprimento regular e equilibrado de combustível nuclear para todos os membros, determina inspeções compulsórias e prevê sanções drásticas em caso de descumprimento.

Para se compreender melhor o nível de aprimoramento do regime instituído pela EURATOM, que previne e dificulta o descumprimento dos Estados membros, vale resumir brevemente como são previstas as inspeções neles. Conforme o art. 81 do seu tratado ${ }^{23}$, caso determinado membro recuse a aceitar inspeções periódicas, a comissão poderá recorrer diretamente ao Presidente da Corte de Justiça da União Europeia, solicitando uma ordem para a realização compulsória da inspeção. O prazo para a concessão dessa ordem é de três dias, e, se houver uma ameaça representada por qualquer atraso, a própria comissão pode emitir essa ordem, que será submetida para a aprovação posterior do Presidente da Corte de Justiça da União Europeia. Depois da expedição dessa ordem, as autoridades do país em questão deverão assegurar aos inspetores pleno acesso aos lugares especificados na decisão.

Apesar de o regime internacional estabelecido no TNP prever a atuação do Conselho de Segurança, não há como equipará-la a essa previsão do art. 81, tanto em termos de agilidade, quanto em relação à eficácia e desprendimento de agendas políticas. Não se pode esquecer que o nível de desenvolvimento institucional dos organismos que compõem a União Europeia ${ }^{24}$, e sua autoridade, não se verifica no sistema da ONU.

21 EUROPEAN UNION. Consolidated Version of the Treaty establishing the European Atomic Energy Community (2012/C, 327/01). Official Journal of the European Union, 26 Oct. 2012. Disponível em: <http://eur-lex.europa.eu/legal-content/EN/TXT/PDF/?uri=CELEX:12012A/TXT\&from=EN>. Acesso em: 20 nov. 2014.

22 LOUKA, Ellie. Nuclear Weapons, Justice and the Law. Cheltenham: Edward Elgar, 2011, p. 282.

23 EUROPEAN UNION. Consolidated Version of the Treaty establishing the European Atomic Energy Community (2012/C, 327/01). Official Journal of the European Union, 26 Oct. 2012. Disponível em: <http://eur-lex.europa.eu/legal-content/EN/TXT/PDF/?uri=CELEX:12012A/TXT\&from=EN>. Acesso em: 20 nov. 2014.

24 Ver CASELLA, Paulo Borba. União Europeia - instituições e ordenamento jurídico. São Paulo: Ltr, 2012. 
No âmbito bilateral, uma experiência válida é a verificada no acordo de uso pacífico de energia nuclear entre Brasil e Argentina, de $1990^{25}$, posteriormente submetido ao monitoramento da AIEA $^{26}$, o que atribuiu maior transparência e controle sobre a iniciativa dos dois países.

A AIEA, como foi observado, desempenha função essencial para a operacionalidade do TNP, verificando o cumprimento das obrigações nele estabelecidas. Contudo, logo foram notadas falhas que comprometiam o êxito de suas atividades, o que ficou claramente exposto na experiência do Iraque logo depois do conflito causado pela sua invasão do Kuwait. Essa circunstância marcou uma importantíssima alteração no regime das salvaguardas e da atuação do Conselho de Segurança.

\subsection{Superação das limitações e fragilidades das salvaguardas}

Inicialmente, as salvaguardas baseavam-se fundamentalmente na aferição da quantidade de combustível nuclear utilizado e na avaliação do material irradiado pelos reatores nucleares e submetido a reprocessamento químico e/ou descarte, uma espécie de contabilidade para verificar se não havia a dispersão de qualquer quantidade de material físsil. Além disso, as inspeções recaíam exclusivamente nos locais e instalações declarados pelos Estados e por eles apontados como passíveis de serem submetidos ao regime de salvaguardas.

As salvaguardas eram criticadas pelo seu viés estreito, já que baseadas na declaração unilateral de materiais, locais e estruturas pelos próprios países a serem inspecionados. Além disso, as inspeções eram dificultadas porque dependiam do consentimento necessário para o ingresso dos inspetores, o que contrariava o estatuto da AIEA que estipulava que mera consulta prévia seria necessária ${ }^{27}$.

Ao lado dessas críticas, reconhecia-se que a agência era insuficientemente financiada e contava com insuficiente quadro de inspetores, decorrência da fragilidade imposta por

25 IAEA. Information Circular. Infcirc/395. 26 Nov. 1991. Agreement between the Republic of Argentina and Federative Republic of Brazil for the exclusively peaceful use of nuclear energy. Disponível em: <http://www.iaea.org/sites/default/files/publications/documents/infcircs/1991/infcirc0395.pdf>. Acesso em: 20 nov. 2014.

26 Disponível em: <http://www.iaea.org/sites/default/files/publications/documents/infcircs/2000/infcirc 435.pdf>. Acesso em: 20 nov. 2014.

27 LOUKA, Ellie. Nuclear Weapons, Justice and the Law. Cheltenham: Edward Elgar, 2011, p. 108-109. 
interesses políticos contrários aos objetivos da não proliferação. Mais ainda, era evidente que o modo como tinham sido estipuladas as salvaguardas apenas permitia que fosse verificado o desvio de materiais, mas não havia mecanismos adequados para prevenir e confrontar programas nucleares clandestinos ${ }^{28}$.

Ainda para corroer a eficácia do regime de salvaguardas, era comum aos países alegarem interesses nacionais como justificativa para restringir ou mesmo impedir as verificações e inspeções pela agência. Como o TNP previa o direito de desenvolvimento de energia nuclear para fins civis, e que as salvaguardas deveriam ser implementadas sem prejudicar o desenvolvimento econômico e tecnológico dos Estados, estes alegavam que pretendiam proteger segredos tecnológicos para impedir as inspeções ${ }^{29}$.

Às vezes, a recusa de inspeções decorria simplesmente de justificativas de cunho político, como a alegação de que os inspetores teriam nacionalidade de Estados não submetidos ao regime de salvaguardas ou não partes do TNP. Há registros ainda de recusas por Estados que não aceitaram inspetores sem fluência na língua espanhola e, durante a Guerra Fria, oriundos de países socialistas. ${ }^{30}$

Sobre a relutância dos Estados em aceitarem o ingresso dos inspetores, independente das justificativas eventualmente alegadas, é relevante considerar como fator adicional a circunstância de que apesar de "os inspetores serem formalmente funcionários da AIEA, em geral são técnicos altamente qualificados nacionais de países desenvolvidos, com interesse em manter o oligopólio nuclear militar e também civil” ${ }^{31}$.

Essas circunstâncias acarretavam graves obstáculos para o sucesso da atuação da AIEA, incapaz de lidar com ocorrências como a remoção clandestina de materiais de um local monitorado, o uso de local monitorado para reprocessamento de material não declarado, a inutilização de equipamentos instalados pela AIEA, a falsificação de registros e relatórios, a utilização de materiais de outras instalações para repor material desviado para programas clandestinos e a recusa de inspeções.

28 MURPHY, John F. Force and Arms. In: SCHACHTER, Oscar; JOYNER, Christopher. C. (Eds.). United Nations Legal Order. Cambridge: American Society of International Law, 1995, p. 313. v. 1.

29 LOUKA, Ellie. Nuclear Weapons, Justice and the Law. Cheltenham: Edward Elgar, 2011, p. 100.

30 Ibidem, p. 109.

31 RAMINA, Larissa; CUNHA FILHO, Valter Fernandes da. Segurança internacional. Curitiba: Juruá, 2013, p. 167. 
Depois que o Iraque invadiu o Kuwait, em 1990, houve uma retaliação internacional que atacou o país, em 1991, para liberar o Estado invadido. Naquele momento, as forças de coalizão internacional depararam-se com a gravíssima descoberta de um programa nuclear clandestino do Iraque:

\begin{abstract}
Apesar dos esforços iraquianos para esconder o máximo possível, nos meses que se seguiram os times de inspeção internacional expuseram um empreendimento nuclear altamente desenvolvido. Ficou evidente que se o esforço nuclear de Saddam não tivesse sido interrompido pela guerra que ele próprio provocara, ele provavelmente teria armas nucleares ainda no início dos anos $1990^{32}$.
\end{abstract}

Essa descoberta expôs claramente os riscos causados pela fragilidade do regime de salvaguardas, já que sistemas de verificação precários são ainda piores do que sua ausência pelas falsas expectativas geradas, considerando que causam uma sensação de segurança que não existiria caso fosse revelada a realidade ${ }^{33}$. Sem qualquer exagero, ficou evidente que o regime de não proliferação era retoricamente formidável, mas, na prática, poroso e permissivo $^{34}$.

A reação foi uma reformulação no sistema de salvaguardas da AIEA. Conforme o sumário elaborado pelo secretariado da agência por ocasião da Conferência de Revisão do TNP de $2010^{35}$, a descoberta do programa iraquiano clandestino evidenciou a necessidade de fortalecimento do sistema de salvaguardas de modo a capacitar a agência para detectar possíveis materiais e atividades nucleares não declarados.

Ainda segundo esse sumário, como resultado o Conselho de Governos afirmou, em 1992, que o escopo dos acordos de salvaguarda não se limitavam a materiais declarados, ou seja, reconhecia a obrigação e o direito da agência de verificar se as declarações de materiais nucleares submetidos às salvaguardas eram corretas e completas.

32 BUNDY, McGeorge, CROWE JR., William J.;. DRELL, Sidney D. Reducing Nuclear Danger - The Road Away from the Brink. New York: Council on Foreign Relations Press, 1993, p. 55, tradução livre do original em inglês.

33 LOUKA, Ellie. Nuclear Weapons, Justice and the Law. Cheltenham: Edward Elgar, 2011, p. 122.

34 BUNDY, McGeorge, CROWE JR., William J.; DRELL, Sidney D., op. cit., p. 59-60.

35 UNITED NATIONS. 2010 Review Conference of the Parties to the Treaty on the Non-Proliferation of Nuclear Weapons. NPT /CONF. 2010/25. Disponível em: <http://www.un.org/ga/search/view_doc.asp?symbol=NPT/CONF.2010/25>. Acesso em: 9 dez. 2014. 
Essa afirmação foi um catalisador importante para equipar as salvaguardas com importantes ferramentas novas necessárias para o desempenho desse espectro mais amplo das verificações a serem realizadas a partir de então, culminando na aprovação do modelo de protocolo adicional ${ }^{36}$ aos acordos de salvaguardas então estabelecidos, pelo qual se fortalecia e aprimorava a eficiência do sistema de salvaguardas como contribuição aos objetivos globais de não proliferação.

A já citada Louka expressa com precisão essa profunda alteração, reconhecendo que a AIEA deixava de ser mera auditora internacional, transformando-se num órgão efetivamente de verificação que procurava informações e fazia inquirições além do que os Estados pretendiam conceder ${ }^{37}$.

O modelo do Protocolo Adicional para os acordos de salvaguardas estabeleceu um mecanismo para acessos complementares que ultrapassavam as inspeções de rotina estabelecidas anteriormente, permitindo aos inspetores da AIEA que visitassem qualquer local no território dos Estados partes para resolver toda inconsistência nas informações prestadas para a agência ${ }^{38}$.

A rigidez estabelecida pelo Protocolo Adicional de 1997, ao lado dos amplos poderes atribuídos ao novo sistema de inspeções, foi muito questionada quanto aos efeitos de interferirem negativamente sobre o direito dos Estados de desenvolverem programas nucleares pacíficos, e de terem seus segredos tecnológicos protegidos ${ }^{39}$.

Essa percepção tornou sua aceitação extremamente controvertida, não tendo sido universalmente bem recebido. O Brasil, por exemplo, mesmo não sendo um país com pretensões proliferadoras, tendo sido um dos países envolvidos na elaboração do Estatuto

36 Disponível em: <http://www.iaea.org/sites/default/files/publications/documents/infcircs/1997/infcirc 0540.pdf>. Acesso em: 27 nov. 2014.

37 LOUKA, Ellie. Nuclear Weapons, Justice and the Law. Cheltenham: Edward Elgar, 2011, p. 110.

38 ASADA, Masahiko. The Challenge Inspection System of the CWC. In: THAKUR, Ramesh; HARU, Ere (Orgs.).The Chemical Weapons Convention. Tokyo: United Nations University, 2006, p. 93-94.

39 RAMINA, Larissa; CUNHA FILHO, Valter Fernandes da. Segurança internacional. Curitiba: Juruá, 2013, p. 161. 
da AIEA, considerado inclusive um de seus membros fundadores ${ }^{40}$, e que é parte do TNP desde $1998^{41}$, até hoje não aderiu ao Protocolo Adicional.

Na diplomacia nacional a adesão é tratada com cautela e constitui motivo de intensa discussão, sendo emblemático o debate entre Samuel Pinheiro Guimarães e Rubens Ricupero $^{42}$. Guimarães o classifica como um instrumento desnecessário e humilhante, destacando a relutância das potências nucleares em se desfazerem de seus arsenais atômicos, assim como criticando crescentes restrições à difusão de tecnologia sob o pretexto de evitar a proliferação, para concluir que o protocolo representaria violação inaceitável da soberania nacional diante da natureza pacífica das atividades nucleares do país.

Ricupero, por seu turno, não considera que a adesão seria contrária aos interesses nacionais. Exatamente ao destacar o aspecto pacífico das iniciativas nacionais, aponta que não haveria nada a temer ou esconder para justificar a recusa na adesão do país. Acrescenta ainda o risco gratuito de o Brasil sofrer restrições à exportação ou importação de urânio enriquecido e tecnologia, prevendo que essas medidas ocorrerão para impor maior adesão internacional ao Protocolo Adicional.

Apesar da controvérsia, o fato é que o Protocolo Adicional, mesmo sendo criticado com base em argumentos políticos, representa relevante meio de se fortalecer o regime de não proliferação nuclear.

Paralelamente às mudanças da AIEA para superar as falhas que propiciaram o desenvolvimento clandestino do programa nuclear iraquiano, toda a postura do Conselho de Segurança foi alterada em relação ao tema, resultante de um esforço sem precedentes para reforçar a luta contra armas de destruição em massa ${ }^{43}$.

40 FISCHER, David. History of the International Atomic Energy Agency: the First Forty Years. Vienna: The Agency, 1997, p. 23 e 41. Disponível em: <http://www-pub.iaea.org/MTCD/publications/PDF/ Pub1032_web.pdf>. Acesso em: 30 jun. 2013.

41 UNODA. Brazil: Accession to Treaty on the Non-Proliferation of Nuclear Weapons (NPT). 18 set. 1998. Disponível em:<http://disarmament.un.org/treaties/a/npt/brazil/acc/washington>. Acesso em: 15 nov. 2014.

42 PROTOCOLO adicional ao TNP: duas visões contrastantes. (Chamada de 12 abr. 2010 de Paulo Roberto de Almeida, autor do blog, que a seguir reproduz dois artigos do caderno Opinião, do jornal Folha de São Paulo, de 10 abr. 2010.) Disponível em: <http://diplomatizzando.blogspot.com.br/2010/04/2082protocolo-adicional-ao-tnp-duas.html>. Acesso em: 28 nov. 2014.

43 MURPHY, John F. Force and Arms. In: SCHACHTER, Oscar; JOYNER, Christopher. C. (Eds.). United Nations Legal Order. Cambridge: American Society of International Law, 1995, p. 301. v. 1. 
O maior reflexo desse esforço residiu na subversão da premissa em que foram assentadas as eventuais sanções contra os proliferadores de armas nucleares. $\mathrm{O}$ respeito dos Estados partes ao regime estabelecido nas salvaguardas previstas no TNP passou a ser avaliado num padrão de total transparência incorporado às resoluções impostas pelo Conselho de Segurança contra países suspeitos de cometerem atividades proliferadoras ${ }^{44}$.

Nesse sentido, as resoluções aprovadas contra o Iraque ao longo dos anos 1990, e, num segundo momento, contra o Irã e a Coreia do Norte, partiram da exigência de transparência integral sobre programas nucleares dos Estados suspeitos de manterem programas clandestinos de armas. Conforme Louka, coube aos Estados suspeitos de tais atividades a demonstração inequívoca de que não as possuíam, com a inversão do ônus de prova para que eles próprios, por possuírem informações mais atualizadas e adequadas, demonstrassem que seus programas nucleares não representavam ameaça ao regime de não proliferação $^{45}$.

Ainda segundo a autora, uma ordem efetiva de não proliferação seria altamente custosa, e de difícil consecução. Assim, caso os Estados não possuíssem nada a esconder, não haveria razão para se negarem a prover total transparência sobre suas atividades nucleares. Adicionalmente, o sistema de não proliferação fora substancialmente fortalecido à medida que as

resoluções do Conselho de Segurança impondo total transparência sobre o tema contra Estados suspeitos teriam caráter vinculante, independentemente de os suspeitos serem partes do TNP, ou mesmo ter em ou não aderido a algum outro instrumento de não proliferação ${ }^{46}$.

Ainda que seja aceito certo papel legiferante do Conselho de Segurança, decorrente da função central que possui no sistema de segurança da ONU, sua seletividade política acaba transcendendo a limitação da natureza jurídica desse papel. Acaba-se integrando à interpretação de normas de Direito Internacional um conteúdo essencialmente político e discricionário ${ }^{47}$, circunstância que possui efeitos muito negativos no que tange à

44 LOUKA, Ellie. Nuclear Weapons, Justice and the Law. Cheltenham: Edward Elgar, 2011, p. 154.

45 Ibidem, p. 135.

46 Ibidem, p. 136.

47 MORE, Rodrigo Fernandes. O desarmamento no sistema de segurança coletiva da ONU. 2005. Tese (Doutorado) - Faculdade de Direito, Universidade de São Paulo, São Paulo, 2002, p. 111. 
imposição da total transparência mesmo contra Estados não vinculados a tratados e regimes de não proliferação.

Esse viés negativo pode advir da reação de Estados partes de determinado tratado ao verificar que o Conselho atua sem estar vinculado aos procedimentos e mecanismos negociados bilateral ou multilateralmente. Ao aderirem a tratados, os estados partes concordam com mecanismos de verificação e aplicação neles previstos. Caso se espere do Conselho que desrespeite esses mecanismos, os estados poderão se sentir menos inclinados a aderir, ou até mesmo serão incentivados a deles se retirarem, minando a integridade do regime de não proliferação ${ }^{48}$.

Ainda nesse sentido, o próprio comportamento do Conselho, altamente marcado por disputas políticas e controlado pelos membros permanentes, contribui para reforçar os efeitos negativos desse papel legiferante assumido por tal órgão a partir da ameaça de proliferação nuclear iraquiana ${ }^{49}$. Mesmo com essas críticas, não há como ignorar o aprimoramento das bases em que desenvolvida a atuação da AIEA.

É interessante notar que, mesmo com esses reforços significativos, o sistema de verificações e monitoramento da AIEA permanecia dependente das vontades políticas, que poderiam atribuir mais força para assegurar sua efetividade se assim fosse do interesse das nações mais poderosas. Nesse sentido, a comissão de inspeção, monitoramento e verificação (UNMOVIC) instituída para atuar no Iraque, em 1999, teve de aguardar até as ameaças concretas de massivo ataque militar pelos Estados Unidos, em 2002, para que o então diretor da AIEA, Hans Blix, recebesse autorização para que os inspetores internacionais desempenhassem suas funções 50 .

48 JOHNSTONE, Ian. The Use of Force. In: BOULDEN, James; THAKUR, Ramesh Chandra; WEISS, Thomas George (Coords.). The United Nations and Nuclear Orders. Tokyo: United Nations University, 2009 , p. 140.

49 MÜLLER, Harald. Verification and Compliance. In: BOULDEN, James; THAKUR, Ramesh Chandra; WEISS, Thomas George (Coords.). The United Nations and Nuclear Orders. Tokyo: United Nations University, 2009, p. 157. Ver ainda: LOPEZ, George A.; CORTIRIGHT, David. United Nations Sanctions and Nuclear Weapons. In: BOULDEN, James; THAKUR, Ramesh Chandra; WEISS, Thomas George (Coords.). The United Nations and Nuclear Orders. Tokyo: United Nations University, 2009, p. 114; SALIBA, Aziz Tuffi. Conselho de Segurança da ONU - sanções e limites jurídicos. Curitiba: Juruá, 2008, p. 153.

50 BOULDEN, James; THAKUR, Ramesh Chandra; WEISS, Thomas George. The United Nations and Nuclear Orders: Context, Foundations, Actors, Tools, and Future Prospects. In: United Nations and Nuclear Orders. Tokyio: United Nations University, 2009, p. 8-9. (Coords.). The 
Também é importante registrar que existem sérias dúvidas em relação à efetividade das sanções como mecanismo eficaz para fortalecer o regime de não proliferação. Segundo Mohamed El Baradei, ex-diretor da AIEA, em entrevista concedida à Reuters em 25 de novembro de 2009, a aplicação sucessiva de sanções contra o Irã muitas vezes se mostra como expressão frustrante de que nada está de fato sendo alcançado para conter as ameaças daquele país contra suas obrigações assumidas no $\mathrm{TNP}^{51}$.

Nesse exato sentido, El Baradei vai além e urge a comunidade internacional a cessar planos de ataques contra proliferadores porque mesmo as ameaças criam justificativas e pretextos para esses Estados decidirem insistir em suas atividades ilegais.

Feita a ressalva contra possíveis efeitos negativos dessas sanções aplicadas pelo Conselho de Segurança, apesar dessas críticas à extrapolação das funções do Conselho, e das fragilidades que remanesciam no sistema de salvaguardas, a experiência iraquiana depois da guerra de 1991 deve ser exaltada como um sucesso. O novo sistema de inspeções, associado à inversão dos ônus de prova, revelou-se muito mais exitoso do que o anterior à invasão do Iraque em 2003, tendo sido confessado pelo próprio Hans Blix que o mundo conseguiu desarmar o Iraque, mesmo sem o saber ${ }^{52}$.

Essa descrença em relação à funcionalidade do sistema decorria do viés ideológico e político, que impedia uma avaliação idônea dos registros dos avanços da UNMOVIC e do desmantelamento das estruturas nucleares clandestinas que existiam no Iraque. Não havia avaliação política adequada sobre essas conquistas, sendo importante notar que, especialmente em Washington, cada novo relato de estruturas descobertas e desmanteladas, em vez de ser celebrado como passo adicional no desarmamento iraquiano, apenas era visto como confirmação da perfídia do regime de Saddam Hussein ${ }^{53}$.

More chega a afirmar que se fosse respeitada a função das verificações para construir uma confiança positiva internacionalmente, as inspeções no Iraque até 2003, em sua credibilidade, "teriam sido mais do que suficientes para antever o que já se sabia: não

51 Cf. HEINRICH, Mark. Exclusive: ElBaradei says West won't meet Iran atom demand. Reuters edition US, 25 Nov. 2009. Disponível em: http://www.reuters.com/article/2009/11/25/us-nuclear-elbaradeiidUSTRE5AO3DJ20091125>. Acesso em: 17 nov. 2014.

52 LOPEZ, George A.; CORTIRIGHT, David. United Nations Sanctions and Nuclear Weapons. In: BOULDEN, James; THAKUR, Ramesh Chandra; WEISS, Thomas George (Coords.). The United Nations and Nuclear Orders. Tokyo: United Nations University, 2009, p. 114.

53 Ibidem, p. 116. 
existiam armas de destruição em massa" 54 naquele país quando da invasão norteamericana.

Independente do equivocado uso que se fez dos relatórios sobre o desmantelamento do programa secreto iraquiano, verifica-se que houve significativa melhora das condições em que estava fundado o sistema de atuação da AIEA, assim como expressivo reforço da atuação do Conselho de Segurança como garante do regime de não proliferação. São mostras de que, apesar dos percalços e das fragilidades desse regime, a sua evolução é plenamente observável.

Verificadas as estruturas centrais do regime de não proliferação, serão analisados, na sequência, meios suplementares destinados a reforçá-lo e a pressionar o mundo no sentido do banimento das armas nucleares.

54 MORE, Rodrigo Fernandes. O desarmamento no sistema de segurança coletiva da ONU. 2005. Tese (Doutorado) - Faculdade de Direito, Universidade de São Paulo, São Paulo, 2002, p. 281. 


\section{AS ZONAS LIVRES DE ARMAS NUCLEARES}

Tendo sido analisada a estrutura central de enfrentamento da questão nuclear, constituída pelo TNP, AIEA e Conselho de Segurança, fica evidente que seu principal foco é conter a proliferação de armas nucleares, tendo se verificado poucas iniciativas em prol do desarmamento nuclear.

Diante dessa ausência, reconhecendo-se que em vez do "controle da proliferação das armas atômicas, o melhor seria a proscrição desse tipo de arma", internacionalmente para se obter esse objetivo foi a criação de zonas limitadas geograficamente nas quais se proibiria a existência de armamento nuclear.

Assim, depois de anos de frustração da expectativa de verem cumprida a meta do desarmamento prevista no TNP, os Estados identificaram que poderiam obter efetivo desarmamento nuclear pela proibição de armas nucleares gradualmente, região por região, celebrando tratados para o estabelecimento de Zonas Livres de Armas Nucleares ${ }^{2}$.

Como já foi analisado nesta dissertação, a criação de acordos regionais era prevista no art. VII, do TNP, apesar de a primeira iniciativa nesse sentido anteceder em um ano a celebração do tratado, com a assinatura do Tratado para a Proscrição das Armas Nucleares na América Latina, ou Tratado de Tlatelolco ${ }^{3}$.

A razão dessa iniciativa precursora foram os temores causados regionalmente pela sequência dos eventos que ficou conhecida como a Crise dos Mísseis, em 1962, quando a América Latina viu-se no epicentro de um confronto que quase deflagrou na região o primeiro uso de armas nucleares desde a Segunda Guerra Mundial, pela simples fato de terem sido alocadas armas nucleares em um daqueles eventos:

A iminência de um confronto atômico entre os EUA e a URSS, motivado pela possibilidade da instalação de uma base de projéteis para disparos com ogivas nucleares em Cuba, colocou os países da América Latina em

1 MAGALHÃES JÚNIOR, Japy Montenegro; MARQUES, Fernando Mário Rodrigues. A proliferação nuclear. Revista de Administração Pública, Rio de Janeiro, v. 12, n. 4, p. 173-197, out./dez.1978. Disponível em: <www.spell.org.br/documentos/download/15540>. Acesso em: 15 nov. 2014, p. 174.

2 LOUKA, Ellie. Nuclear Weapons, Justice and the Law. Cheltenham: Edward Elgar, 2011, p. 102.

3 IAEA. Treaty for the Prohibition of Nuclear Weapons in Latin America (Tlatelolco Treaty). (Reproduced from United Nations document A/6663.) Disponível em: <http://www.iaea.org/Publications/Documents/Treaties/tlatelolco.html>. Acesso em: 17 nov. 2014. 
alerta devido ao temor de que seus territórios pudessem vir a ser envolvidos em planos estratégicos, e levou-os à elaboração do Tratado para a Proscrição das Armas Nucleares na América Latina. ${ }^{4}$

Atualmente, existem cinco zonas livres de armas nucleares, América Latina e Caribe, Pacífico Sul, África, Sudeste Asiático e Ásia Central. Antes de se analisar com mais vagar cada um desses tratados, cabe ainda tecer algumas considerações gerais que se aplicam a todos eles. Conforme foi adiantado aqui, essa iniciativa consistiu num meio identificado para o banimento gradual das armas nucleares à medida que era ampliado o seu âmbito de restrição geográfica. Reconheceu El Baradei, na celebração de 40 anos da assinatura do Tratado de Tlatelolco:

hoje em dia existem cinco zonas livres de armas nucleares que cobrem quase dois terços dos continentes do mundo e virtualmente todo o hemisfério sul. Efetivamente, as zonas livres de armas nucleares constituem importante passo para que se obtenha um mundo livre de armas nucleares ${ }^{5}$.

Além de representar uma restrição cada vez mais abrangente do espaço geográfico em que se admite a existência de armas nucleares, esses tratados declaram a "ilegitimidade dessas armas, consideradas meios inaceitáveis para a atuação em conflitos armados, ao ponto que alguns Estados escolhem não ter de tolerá-las em sua vizinhança”. Nesse aspecto, a relevância da inciativa verifica-se também pela "denúncia moral das armas nucleares" 6 .

Em linhas gerais, não há grande complexidade na compreensão do que é uma zona livre de armas nucleares, classificação que descreve circunstância regional em que os Estados nela inseridos estabelecem um tratado ou convenção afirmando a proscrição de armas nucleares dentro de seu limite territorial, formalizando os mecanismos de manutenção desse compromisso, conforme estabelecido pela Resolução da Assembleia

4 MAGALHÃES JÚNIOR, Japy Montenegro; MARQUES, Fernando Mário Rodrigues. A proliferação nuclear. Revista de Administração Pública, Rio de Janeiro, v. 12, n. 4, p. 173-197, out./dez.1978. Disponível em: <www.spell.org.br/documentos/download/15540>. Acesso em: 15 nov. 2014, p. 174, p. 184.

5 IAEA. Tlatelolco Treaty A Trailblazer for Non-Proliferation. 14 Feb. 2007. Disponível em: <http://www.iaea.org/newscenter/news/tlatelolco-treaty-trailblazer-non-proliferation>. Acesso em: 18 nov. 2014.

6 LOUKA, Ellie. Nuclear Weapons, Justice and the Law. Cheltenham: Edward Elgar, 2011, p. 167. 
Geral da ONU n 3.472 (XXX), aprovada em 1975, denominada "estudo amplo da questão das zonas livres de armas nucleares em todos os seus aspectos" 7.

As zonas livres de armas nucleares são muito importantes como ferramentas de correção de falhas ou preenchimento de lacunas verificadas na estrutura central formada pela AIEA-TNP, erigida sobre a ameaça de sanções pelo Conselho de Segurança. More enxerga nelas um instrumento complementar "aos esforços globais, ao introduzir um importante elemento de controle de armas, de desarmamento e, por conseguinte, de favorecimento do processo de pacificação" ${ }^{8}$.

Para sua funcionalidade, o sistema de inspeções e verificações estabelecido pela AIEA é essencial para monitorar o cumprimento das obrigações assumidas pelos Estados, sendo previsto em todos os tratados que estabelecem zonas livres de armas nucleares o dever da celebração de acordos entre seus membros e a agência para essa finalidade.

Para evitar que a ameaça de ataques nucleares contra os Estados membros de zonas livres de armas nucleares represente um desestímulo à sua conformação, todos os tratados que estabelecem essas zonas incluem um protocolo a ser assinado pelas cinco potências nucleares reconhecidas pelo TNP. Esses instrumentos, conhecidos como garantias de segurança negativas, demandam que essas potências respeitem o status dessas zonas e não ataquem ou ameacem com armas nucleares quaisquer de seus membros. Entretanto, como será observado ao se analisar cada um dos cinco tratados, as potências nucleares costumam impor reservas ao aderir a esses protocolos, minando essas iniciativas ${ }^{9}$.

Davenport e Kimball citam alguns exemplos desse comportamento:

Os EUA, ao assinarem o Protocolo relativo à zona africana livre de armas nucleares, em abril de 1996, declarou que se reservava o direito de responder por qualquer meio, implicando a possibilidade de uso de armas nucleares, contra um ataque químico ou biológico cometido por um Estado membro. Mais ainda, nenhuma nação nuclear assinou o protocolo ao tratado que criou a zona livre de armas nucleares no Sudeste Asiático

7 UNITED NATIONS. 2437 $7^{\text {th }}$ plenary meeting, 11 Dec. 1975. Disponível em: <http://www.opanal.org/Docs/UN/UNAG30res3472i.pdf>. Acesso em: 7 dez. 2014.

8 MORE, Rodrigo Fernandes. O Desarmamento no sistema de segurança coletiva da ONU. 2005. Tese (Doutorado) - Faculdade de Direito, Universidade de São Paulo, São Paulo, 2002, p. 251.

9 DAVENPORT, Kelsey; KIMBALL, Daryl G. Nuclear-Weapon-Free Zones (NWFZ) at a Glance. Disponível em: http://www.armscontrol.org/factsheets/nwfz . Acesso em: 18 nov. 2014. 
devido às preocupações relacionadas ao possível conflito que teria contra a liberdade de movimento em águas e espaço aéreo internacionais. ${ }^{10}$

Trata-se de um viés negativo. Considerada a não ratificação de alguns protocolos, a demora na ratificação de outros, e as reservas a suas ratificações, pode-se afirmar que as potências nucleares não são entusiastas ou apoiadores dos tratados que criam zonas livres de armas nucleares ${ }^{11}$.

Verificadas as linhas gerais desses tratados, segue rápida consideração individual acerca de cada um deles.

\subsection{Tratado de Tlateloco}

Como já foi antecipado, o primeiro desses tratados foi portanto o de Tlatelolco, assinado em 1967 e que, por sua originalidade, acabou servindo de modelo aos demais que o sucederam. Já em seu preâmbulo ${ }^{12}$, além do alerta sobre o caráter destrutivo e o risco colocado para o mundo pela mera presença das armas nucleares, foi explicitado seu objetivo de influenciar as demais regiões do mundo a se tornarem livres de armas nucleares.

Pesem os aspectos auspiciosos dessa iniciativa internacional, há que se manter sempre "os pés no chão" para a avaliar corretamente, uma vez que, também nessa frente, os avanços são obtidos lentamente, sempre se tendo de superar percalços de natureza política que contrariam os objetivos principais a serem atingidos.

A título de ilustração, é digno de nota que, apesar de datar de antes do TNP, apenas no século XXI foi possível considerar que fora realizada a meta do Tratado de Tlatelolco de estabelecer uma zona livre de armas nucleares compreendendo a América Latina e o

10 NUCLEAR-WEAPON-FREE ZONES (NWFZ) At a Glance. Press Contacts: Kelsey Davenport and Daryl Kimball. (Posted 15 Dec. 2009, updated Sep. 2012.) Arms Control Association. Disponível em: http://www.armscontrol.org/factsheets/nwfz. Acesso em: 18 nov. 2014.

11 LOUKA, Ellie. Nuclear Weapons, Justice and the Law. Cheltenham: Edward Elgar, 2011, p. 179, tradução livre do original em inglês.

12 IAEA. Treaty for the Prohibition of Nuclear Weapons in Latin America (Tlatelolco Treaty). (Reproduced from United Nations document A/6663.) Disponível em: <http://www.iaea.org/Publications/Documents/Treaties/tlatelolco.html>. Acesso em: 17 nov. 2014. 
Caribe, já que apenas em 2002, com o ingresso efetivo de Cuba, houve a adesão integral dos 33 países da zona ${ }^{13}$.

Em relação à sua execução, além do estabelecimento, no art. 7 do tratado, de um organismo para gerir executivamente o cumprimento das obrigações nele previstas, a Organização pela Proibição de Armas Nucleares na América Latina, ou OPANAL, é importante ainda destacar que cada Estado parte assumiu a obrigação de negociar acordos de salvaguardas com a AIEA (art. 13). Tais acordos deveriam autorizar a agência a conduzir inspeções especiais (art. 16), sendo que, em caso de descumprimento, são previstas punições que vão desde recomendações até denúncias ao Conselho de Segurança da ONU (art. 21).

Por se tratar de uma região em que, além de Estados independentes, ainda há localidades que são submetidas ao controle de países estrangeiros, foi estipulado o Protocolo I adicional ao tratado para evitar brechas que pudessem permitir a presença de armas nucleares nessas áreas sem representar qualquer violação. Esse Protocolo determina a necessidade de desnuclearização também dos territórios inseridos na zona e controlados por outros países, tendo sido assinado por Reino Unido, Holanda, França e Estados Unidos $^{14}$.

Já o Protocolo II $^{15}$ refere-se à obrigação acima antecipada das cinco nações nucleares de não usarem armas nucleares contra os Estados membros da zona delineada pelo Tratado de Tlatelolco, e de nem tampouco os ameaçarem com o seu uso. Apesar de as cinco nações terem assinado esse protocolo, não o fizeram incondicionalmente, impondo ressalvas que ameaçam sua utilidade.

Veja-se, por exemplo, que os EUA explicitaram que deveriam considerar um ataque realizado por um Estado parte do Tlatelolco, em que tenha sido auxiliado por um Estado nuclearmente armado, como incompatível com as obrigações assumidas no art. I do tratado. A França, por sua vez, ao aderir ao Protocolo II, declarou que nenhuma provisão

13 SAMPAIO, Maria Feliciana Nunes Ortigão de. O Tratado de Proibição Completa dos Testes Nucleares $(C T B T)$ : Perspectivas para sua entrada em vigor e para a atuação diplomática brasileira. Brasília: Alexandre de Gusmão, 2012, p. 39.

14 UNODA. Additional Protocol I to the Treaty for the Prohibition of Nuclear Weapons in Latin America and the Caribbean. Protocol to the Treaty of Tlatelolco. Disponível em: <http://disarmament.un.org/treaties/t/tlateloco_p1>. Acesso em: 12 dez. 2014.

15 Ibidem. 
daquele protocolo ou artigo do tratado poderia afetar o exercício da autodefesa, como previsto no art. 51 da Carta da ONU ${ }^{16}$.

É difícil compreender a alegação norte americana, especialmente porque, se o referido ataque, mesmo apoiado por uma nação nuclearmente armada, não envolver o uso nem a ameaça de armas nucleares, em nada seriam afetadas as obrigações previstas no artigo I, que determina o uso exclusivamente pacífico da energia nuclear, proíbe recebimento, estocagem, instalações ou mesmo a posse, assim como testes, manufatura ou aquisição de armas nucleares.

Igualmente, a ressalva francesa teria relevância prática quase impossível, sendo difícil imaginar um ataque de um dos Estados latino-americanos ou caribenhos que pudessem ameaçar a integridade francesa ao ponto de autorizar alguma agressão com base no art. 51 da Carta. Provavelmente, está-se aqui diante do perigoso comportamento de ampliar as hipóteses que autorizam ações previstas no art. 51, como será observado na terceira parte desta dissertação.

Deve ser sublinhado o aspecto deletério decorrente da ressalva apresentada pelas nações nucleares contra os objetivos estabelecidos nos tratados que criam as zonas livres de armas nucleares, mantendo, mesmo remotamente, a possibilidade de que países nuclearmente desarmados sejam ameaçados e constrangidos pelas nações nucleares, colocando em xeque as vantagens que se esperam do pleno funcionamento das zonas livres de armas nucleares. A única das cinco nações nucleares que aderiu ao Protocolo II sem ressalvas foi a China ${ }^{17}$.

\subsection{Tratado de Rarotonga}

O Tratado de Rarotonga ${ }^{18}$, assinado em 1985 e com vigência desde 1986, estabeleceu a zona do Pacífico Sul como uma zona livre de armas nucleares. Nessa região do globo, uma preocupação mais latente dava-se em relação aos testes nucleares que ali foram realizados ao longo de décadas.

16 LOUKA, Ellie. Nuclear Weapons, Justice and the Law. Cheltenham: Edward Elgar, 2011, p. 171.

17 OTT, David H. Public International Law in the Modern World. Londres: Pitman, 1987, p. 329.

18 Disponível em: <http://www.iaea.org/sites/default/files/publications/documents/infcircs/1986/ infcirc0331.pdf>. Acesso em: 18 nov. 2014. 
Por isso é que, além das preocupações e objetivos similares aos que determinaram o Tratado de Tlatelolco, o tratado contém previsão específica sobre o banimento de testes (art. 6), que eram largamente realizados na região. A França usava a Polinésia Francesa para essas atividades e, entre 1966 e 1996, realizou 190 detonações. Já os Estados Unidos utilizavam as Ilhas Marshall, entre 1946 e $1958^{19}$.

O Tratado de Rarotonga conta com três protocolos ${ }^{20}$, que se destinam a vincular as nações nucleares a suas disposições. O Protocolo I tenta impor que respeitem as disposições do tratado nos territórios que controlam dentro da região; o Protocolo II referese à garantia negativa de segurança para não atacarem ou ameaçarem ataques com armas nucleares contra os Estados membros; e o Protocolo III refere-se à obrigação de não realização de testes nucleares no território compreendido pelo tratado.

O Protocolo I foi ratificado apenas pela França e pelo Reino Unido ${ }^{21}$, com ressalva francesa similar à de Tlatelolco; o Protocolo $\mathrm{II}^{22}$, à exceção dos EUA, foi ratificado por todas as potências nucleares; já o Protocolo III $^{23}$ também não conta apenas com a ratificação norte-americana.

Justamente para evitar que a eficácia do tratado fosse colocada em xeque devido a impasses políticos refletidos nessas ressalvas e na ausência de ratificação integral dos protocolos adicionais, ele foi dimensionado sem a inclusão da Federação de Estados da Micronésia, as Ilhas Marshall e Palau, que ainda não são partes devido a interesses e atividades das potências nucleares, apesar de se situarem na zona abrangida pelo tratado ${ }^{24}$.

19 LOUKA, Ellie. Nuclear Weapons, Justice and the Law. Cheltenham: Edward Elgar, 2011, p. 171.

20 Disponível em: <http://www.iaea.org/sites/default/files/publications/documents/infcircs/1986/331a1 .PDF>. Acesso em: 18 nov. 2014.

21 UNODA. Protocol 1 to the South Pacific Nuclear Free Zone Treaty. Protocol to the Treaty of Rarotonga. Opened for Signature: 1 Dec. 1986. Disponível em: 〈http://disarmament.un.org/treaties/t/rarotonga_p1〉. Acesso em: 15 dez. 2014.

22 UNODA. Protocol 2 to the South Pacific Nuclear Free Zone Treaty. Protocol to the Treaty of Rarotonga. Opened for Signature: 1 Dec. 1986. Disponível em: 〈http://disarmament.un.org/treaties/t/rarotonga_p2〉. Acesso em: 15 dez. 2014.

23 UNODA. Protocol 3 to the South Pacific Nuclear Free Zone Treaty. Protocol to the Treaty of Rarotonga. Opened for Signature: 1 Dec. 1986. Disponível em: 〈http://disarmament.un.org/treaties/t/rarotonga_p3〉. Acesso em: 15 dez. 2014.

24 LOUKA, op. cit., p. 171. 


\subsection{Tratado de Bangkok}

O Tratado de Bangkok, assinado em 1995, estabeleceu o Sudeste Asiático como uma zona livre de armas nucleares. Apesar das similaridades com os dois tratados analisados acima, ele possui escopo mais amplo por abranger, além dos territórios nele previstos, as plataformas continentais a eles relativas, assim como por prever que zonas exclusivas econômicas dos Estados partes são também regiões abrangidas pelo tratado ${ }^{25}$.

Ao lado dessa ampliação em termos geográficos e geopolíticos, o tratado é também materialmente mais amplo, por proibir inclusive o trânsito de armas nucleares na área compreendida por ele.

Apesar desses avanços em suas proposições, por contrariarem interesses estratégicos dos Estados nuclearmente armados, o resultado prático acabou sendo negativo devido à recusa desses Estados ao protocolo adicional estabelecido para que passassem a assumir para si as obrigações previstas no tratado ${ }^{26}$.

Essa recusa perdura até hoje, persistindo por quase duas décadas desde a celebração do tratado, circunstância que impede que ele atinja sua capacidade operacional plena.

\subsection{Tratado de Pelindaba}

O Tratado de Pelindaba ${ }^{27}$, assinado em 1996, e com vigência desde 2009, estabeleceu o continente africano como uma zona livre de armas nucleares. Sua iniciativa remonta à Resolução 1652 (XVI) da Assembleia Geral da ONU², aprovada em 1961 em resposta à realização de testes franceses realizados no Sahara em 1960.

Essa longa espera entre a aprovação da resolução e a sua entrada em vigor, ocorrida apenas em 2009, reflete bem a dificuldade para que essas iniciativas sejam finalmente concretizadas.

25 UNODA. Treaty on the Southeast Asia Nuclear Weapon-Free Zone. Opened for signature at Bangkok: 15 Dec. 1995. Disponível em: <http://disarmament.un.org/treaties/t/bangkok/text〉. Acesso em: 18 nov. 2014.

26 UNODA. Protocol to The Treaty on Southeast Asia Nuclear Weapon-Free Zone. Protocol to the Bangkok Treaty. Disponível em: <http://disarmament.un.org/treaties/t/bangkok_protocol\#>. Acesso em: 18 nov. 2014.

27 UNODA. African Nuclear Weapon Free Zone Treaty. Treaty of Pelindaba. Signed at Cairo: 11 April 1996. Disponível em: 〈http://disarmament.un.org/treaties/t/pelindaba/text〉. Acesso em: 18 nov. 2014.

28 Disponível em: <http://daccess-dds-ny.un.org/doc/RESOLUTION/GEN/NR0/167/05/IMG/NR016705 .pdf?OpenElement>. Acesso em: 6 dez. 2014. 
Apesar da resolução da década de 1960, apenas em 1991 a África do Sul renunciou ao seu programa de armas nucleares, ocasião em que foram superados os obstáculos que impediam a adoção do tratado na prática, permitindo sua assinatura em 1996. Ainda assim, passaram treze anos para que entrasse em vigor.

Existem três protocolos adicionais ao Tratado de Pelindaba, todos marcados por ressalvas e posturas reativas similares às já mencionadas. É digno de nota que os EUA não assinaram quaisquer desses protocolos adicionais, demonstrando a vagueza de seu posicionamento internacional em relação ao tema ${ }^{29}$. Enquanto apoia essas iniciativas em regiões que considera de menor potencial de ameaças contra seus interesses, sua conduta é diametralmente oposta quando se refere a áreas em que seus interesses estão mais estrategicamente vinculados ou ameaçados.

\subsection{Tratado sobre a Ásia Central}

O Tratado que estabeleceu a Ásia Central como uma zona livre de armas nucleares ${ }^{30}$ foi assinado em 2006, e entrou em vigor em 2009.

Sua celebração decorreu de uma declaração conjunta do Cazaquistão, Quirguistão, Tajiquistão, Turcomenistão e Usbequistão, conhecida como Declaração Almaty, de 1997, endossando a criação de uma zona livre de armas nucleares na região compreendida pelos territórios de seus países em conjunto.

A zona livre de armas nucleares da Ásia Central possui uma peculiaridade geopolítica por representar o primeiro tratado adotado numa região altamente armada com armas nucleares e que abriga bases militares americanas e russas ${ }^{31}$.

Devido a essa particularidade, o tratado foi projetado para tentar lidar com essa realidade ao inserir uma condição que diferencia a posse de armas nucleares do seu transporte.

29 UNODA. Protocol I to the Pelindaba Treaty. Protocol to the Pelindaba Treaty. Início das assinaturas: 11 abr. 1996. Disponível em: <http://disarmament.un.org/treaties/t/pelindaba_1>. Acesso em: 18 nov. 2014.

30 UNODA. Treaty on a Nuclear-Weapon-Free Zone in Central Asia (CANWFZ). Opened for signature at Semipalatinsk: 8 Sep. 2006. Disponível em: <http://disarmament.un.org/treaties/t/canwfz/text〉. Acesso em: 18 nov. 2014.

31 LOUKA, Ellie. Nuclear Weapons, Justice and the Law. Cheltenham: Edward Elgar, 2011, p. 177. 
Essa criação é em si mesma contraditória, porque enquanto o tratado obriga os membros a não possuírem armas nucleares, nem permitirem sua alocação em seus territórios, seu art. 4 atribui a liberdade de decidirem, com base no exercício de sua soberania, sobre questões relacionadas ao trânsito de armas nucleares que invadam seu território por ar, terra ou água, incluindo em visitas de navios estrangeiros aos seus portos, ou pelo pouso de aviões estrangeiros em seus aeroportos.

Apesar disso, muito provavelmente por conta dos aspectos geopolíticos e estratégicos verificados na região, até hoje nenhum estado nuclear assinou o protocolo adicional ao tratado ${ }^{32}$, que estende para esses países o regime de obrigações para o funcionamento pleno da zona livre de armas nucleares.

Como foi observado, o papel desempenhado pelos tratados que estabelecem zonas livres de armas nucleares é muito relevante para complementar o complexo de tratados que conformam o regime de não proliferação e luta pelo desarmamento nuclear. Apenas a iniciativa de serem criadas zonas em que a mera existência dessas armas é considerada ilegal já contém, em si própria, enorme significado, uma vez que a ausência de norma ou tratado internacional que declare a ilegalidade das armas nucleares é uma das principais lacunas de que se ressentem aqueles que buscam o desarmamento nuclear ${ }^{33}$.

Ainda assim, não se pode apenas celebrar essas importantes inovações, uma vez que, como foi observado, todas elas enfrentam obstáculos de ordem política impostos pelas potências nucleares para que sejam plenamente implementadas. Seja por meio de ressalvas que contrariem o espírito desses tratados, seja pela não ratificação de seus protocolos, ao agirem assim os estados nucleares acabam rivalizando com os esforços de não proliferação e desarmamento, grave contradição que corrói o regime de não proliferação.

É a repetição da dinâmica já observada quando se analisou a estrutura e as origens do TNP. Enquanto discursam em prol de cooperação na área do desarmamento, suas condutas acabam esvaziando sua retórica.

Para a construção em busca da realidade em que se possa vislumbrar o desarmamento nuclear completo, deve, necessariamente, haver um reforço do clima de

32 UNODA. Protocol to the Treaty on a Nuclear-Weapon-Free Zone in Central Asia (CANWFZ). Início das assinaturas: 6 de maio de 2014. Disponível em: <http://disarmament.un.org/treaties/t/canwfz_protocol〉. Acesso em: 18 nov. 2014.

33 Essa questão será objeto de análise específica na próxima parte deste trabalho. 
confiança internacional, algo que apenas pode ser aventado quando for superada, ou mitigada, essa vagueza e dubiedade das potências nucleares.

Somente com essa mudança é que, ao menos no que tange às zonas livres de armas nucleares, estas não mais serão úteis para expor a inadequação da conduta das principais potências nucleares, mas, diferentemente, poderão propiciar a construção de uma realidade pacífica e harmoniosa.

Pelo esperado aprofundamento da confiança que atribuem às relações entre Estados geograficamente próximos, terão a possibilidade de catalisar novos acordos com outros Estados vizinhos. Paralelamente, poderiam propiciar uma mudança na relação mantida com os Estados-nucleares, com os quais poderão, no lugar de ressalvas aos tratados, ser estabelecidos protocolos de cooperação em defesa em caso de ameaça ou uso de força nuclear por terceiros Estados ${ }^{34}$.

34 MORE, Rodrigo Fernandes. O Desarmamento no sistema de segurança coletiva da ONU. 2005. Tese (Doutorado) - Faculdade de Direito, Universidade de São Paulo, São Paulo, 2002, p. 246-247. 


\section{ELEMENTOS COMPLEMENTARES DO REGIME DE NÃO PROLIFERAÇÃO E DA LUTA PELO BANIMENTO DAS ARMAS NUCLEARES}

\subsection{Considerações gerais}

Nos capítulos anteriores, foram analisados os principais elementos que compõem a estrutura internacional normativa e institucional do regime de não proliferação e da luta pelo banimento das armas nucleares. O tripé composto pelo TNP, a AIEA, e o Conselho de Segurança, ao lado do estabelecimento de zonas geográficas em que é proibida a mera existência de armas nucleares desempenham função relevantíssima para a concretização da meta do desarmamento nuclear.

Contudo, como já apontado anteriormente nesta dissertação, o tratamento dado pela comunidade internacional a esse tema é muito mais multifacetado, refletindo-se num complexo de normas, organizações e mesmo iniciativas não institucionalmente formais que se sobrepõem completamente umas às outras de modo a que eventuais limitações e falhas de algumas sejam supridas por outras ${ }^{1}$. Vale reprisar o registro de que, atualmente, há em vigor 25 tratados multilaterais, regionais ou bilaterais sobre armas nucleares ${ }^{2}$ e uso de energia nuclear.

Essa complexidade decorre da identificação de que diversos problemas verificados nos instrumentos já em vigor apenas podem ser corrigidos pelo estabelecimento de iniciativas que se somam àquelas, para enfrentar dilemas distintos para os quais as normas então aprovadas não haviam sido dimensionadas. Além disso, conforme a evolução das relações internacionais apresenta novos desafios, faz-se necessária a criação de mecanismos aptos a lidar com eles.

Interessante, a título de ilustração, a constatação das principais limitações e inadequações existentes na ordem de não proliferação como o reiterado descumprimento

SAMPAIO, Maria Feliciana Nunes Ortigão de. O Tratado de Proibição Completa dos Testes Nucleares $(C T B T)$ : Perspectivas para sua entrada em vigor e para a atuação diplomática brasileira. Brasília: Alexandre de Gusmão, 2012, p. 26.

2 FINLAY, Brian; GROSSMAN-VERMAAS, Rita. Technology Proliferation, Globalization and the Role of the United Nations. In: BOULDEN, James; THAKUR, Ramesh Chandra; WEISS, Thomas George (Coords.). The United Nations and Nuclear Orders. Tokyo: United Nations University, 2009, p. 195. 
das nações nucleares de se desarmarem conforme previsto no art. VI do TNP, a incapacidade do tratado de lidar com estados que não aderiram a ele e sua limitação para enfrentar ameaças não estatais ${ }^{3}$.

Adicionalmente, as novas iniciativas tornaram-se necessárias para lidar de uma maneira criativa com os obstáculos percebidos pelo insucesso, ou sucesso relativo, da clássica resposta que a ordem internacional da não proliferação vem aplicando contra estados proliferadores. Neste particular, uma avaliação franca reconhece que sanções de longo prazo para punir com embargos econômicos e de transferência de tecnologia, ao lado de incentivos inconsistentes para o desarmamento, falharam para persuadir países que decidiram obter armas nucelares da meta de buscá-las 4 .

Nesse contexto, um fator adicional para complicar o tabuleiro internacional decorre do impulso recente por uma retomada do desenvolvimento de programas nucleares civis. Depois de um período de relativa perda de interesse internacional, especialmente depois do grave acidente ocorrido em 1986, em Chernobyl, o mundo vem testemunhando um crescente número de projetos de diversos países que consideram a matriz energética nuclear como elemento estratégico para desenvolvimento industrial ${ }^{5}$.

Esse movimento é incentivado também pela pressão internacional por uma redução e abandono de combustíveis fósseis, catalisando ainda mais os incentivos para desenvolvimento de programas energéticos nucleares. Digna de nota a descrição dessa tendência, que já vem sendo classificada de renascimento nuclear:

Durante grande parte dos anos 1990, a indústria nuclear era considerada decadente. Vários contratempos acabaram lhe atribuindo uma má reputação para si, o que foi acirrado pela mudança dramática verificada depois do acidente de Chernobyl, na ex-URSS. À medida que engrossaram as demandas para se enfrentarem as ameaças de mudança climática, aumentaram os anseios para o uso da energia nuclear como

3 THAKUR, Ramesh. Has the Good Become the Enemy of the Best? In: BOULDEN, James; THAKUR, Ramesh Chandra; WEISS, Thomas George (Coords.). The United Nations and Nuclear Orders. Tokyo: United Nations University, 2009, p. 279-280.

4 LOPEZ, George A.; CORTIRIGHT, David. United Nations Sanctions and Nuclear Weapons. In: BOULDEN, James; THAKUR, Ramesh Chandra; WEISS, Thomas George (Coords.). The United Nations and Nuclear Orders. Tokyo: United Nations University, 2009, p. 112. Os autores mencionam, na passagem, Índia, Paquistão e Irã, aos quais se podem acrescentar a Coreia do Norte e Israel.

5 BLIX, Hans. Questões sobre a Guerra do Iraque: o uso de força, armas de destruição em massa e as Nações Unidas. In: DUPAS, Gilberto; LAFER, Celso; SILVA, Carlos Eduardo Lins da (Orgs.). A nova configuração mundial do poder. São Paulo: Paz e Terra, 2008, p. 336. 
uma das fontes de energia que poderia reduzir a produção de gases relacionados ao efeito estufa. Um renascimento nuclear reemergiu da era obscura da indústria nuclear ${ }^{6}$.

O renascimento nuclear impõe novos desafios adicionais para o regime de não proliferação, já que à medida que se ampliará o número de Estados com o domínio da tecnologia que envolve o ciclo nuclear, será ampliado na mesma proporção o número de possíveis Estados proliferadores de armas nucleares. Como esse conhecimento pode facilmente ser convertido para uso bélico, essa circunstância torna necessário assegurar a submissão dos novos projetos civis ao regime de inspeções internacionais ${ }^{7}$.

É digno de nota o caráter de certo modo visionário refletido em estudo já citado anteriormente neste trabalho, desenvolvido pelo Comitê de Segurança Internacional e Controle de Armas na Academia Nacional de Ciências dos EUA, datado de 1991, antes, ainda, de ter sido experimentada toda a avalanche de descobertas do programa nuclear iraquiano, de a Índia e do Paquistão terem se tornado Estados nuclearmente armados, do terrorismo internacional ter sido alçado a patamar de ameaça global nunca antes visto, e antes dos desafios impostos pela Coreia do Norte e pelo Irã:

O perigo de proliferação nuclear em áreas instáveis deve se elevar. O aumento da disponibilização comercial de tecnologias avançadas para armas nucleares e seus meios de disparo colocaram-nas tecnicamente ao alcance de um crescente números de países em desenvolvimento, assim como das principais nações industrializadas. Esforços exitosos pelo controle da proliferação nuclear demandarão redução da exigência política de armas nucleares ao lado de medidas efetivas de controle ao suprimento de tecnologias específicas ${ }^{8}$.

Assim, para lidar com essas questões fez-se necessário ultrapassar o modelo consolidado na primeira fase da era nuclear, em que o controle ou o impedimento de

6 LOUKA, Ellie. Nuclear Weapons, Justice and the Law. Cheltenham: Edward Elgar, 2011, p. 78-81-97, tradução livre do original em inglês.

7 Para uma mostra sobre o possível efeito desestabilizador representado pelo renascimento nuclear, ver: LOUKA, op. cit., p. 83, tradução livre do original: “O Conselho de Cooperação do Golfo, uma associação formal de Estados Árabes, declarou em 2006 que estava estudando o desenvolvimento de um programa nuclear conjunto. Esse anúncio gerou a especulação sobre uma possível corrida armamentista na região entre os Estados Árabes e o Irã".

8 Committee on International /Security and Arms Control - National Academy of Sciences. The Future of the U.S. - Soviet Nuclear Relationship. Washington: National Academy, 1991, p. 2, tradução livre do original em inglês. 
acesso ao conhecimento tecnológico seria um instrumento efetivo contra a proliferação nuclear:

\begin{abstract}
Se, nos primeiros cinquenta anos da era nuclear o mecanismo primário para prevenir a proliferação nuclear era o controle estrito de conhecimento, tecnologia e materiais, atualmente esses itens não têm como ser controlados apenas por poucos. O principal meio para que os Estados não nuclearmente armados não exerçam a opção pelas armas nucleares será pela persuasão deles de que os objetivos de longo prazo de segurança serão melhor atendidos pela renúncia a essas armas, com o reforço de medidas em prol de um bem comum ${ }^{9}$.
\end{abstract}

Ao lado desse avanço qualitativo para reforçar uma realidade em que os Estados que serão detentores do conhecimento tecnológico nuclear não se vejam compelidos a adquirirem armas nucleares, o regime de proliferação consolidado nesses primeiros cinquenta anos viu-se também questionado pela incapacidade de lidar com ameaças que não poderiam ser combatidas com base no instrumental que se havia erigido sobre a questão nuclear, especialmente o terrorismo internacional. Os grupos terroristas, nesse sentido, desafiam o monopólio da violência há muito tempo pretendido exclusivamente pelos Estados, e acabam violando as regras que são aplicáveis apenas contra Estados soberanos ${ }^{10}$.

Dadas as limitações verificadas no sistema estatocêntrico para conter as novas ameaças de proliferação nuclear, foram criadas medidas para combatê-las, como tratados específicos sobre terrorismo nuclear, resoluções do Conselho de Segurança, incentivos financeiros e políticos para fortalecer Estados frágeis e instáveis, e até mesmo o surgimento de iniciativas não institucionais, mas de efetividade global, como a Proliferation Security Initiative, medida deflagrada pelos EUA, não institucionalmente formalizada, baseada em acordos bilaterais que permitem a interceptação de navios em águas internacionais para conter o tráfico de materiais e equipamentos que podem ser utilizados para programas nucleares ${ }^{11}$.

9 REGEHR, Ernie. The Security Council and Nuclear Development. In: BOULDEN, James; THAKUR, Ramesh Chandra; WEISS, Thomas George (Coords.). The United Nations and Nuclear Orders. Tokyo: United Nations University, 2009, p. 43, tradução livre do original em inglês.

10 BULL, Hedley. A sociedade anárquica. Tradução de Sérgio Bath. São Paulo: UnB, 2002, p. 227.

11 SIDHU, Waheguru Pal Singh..Dealing with Extra-NPT Actors and Non-State Actors. In: BOULDEN, James; THAKUR, Ramesh Chandra; WEISS, Thomas George (Coords.). The United Nations and 
Essas medidas interligam-se e acabam colaborando umas com as outras, numa espécie de simbiose que acaba fortalecendo o aparato de não proliferação. Nesse sentido, ao serem aprimorados meios de impedir o tráfico de armas e equipamentos a serem utilizados para o desenvolvimento de dispositivos nucleares, acaba-se também robustecendo os meios de fiscalização do comércio de itens e equipamentos que, por suas características, são considerados de uso duplo, ou seja, que podem tanto ser utilizados para o desenvolvimento de programas industriais pacíficos, quanto ser a base de programas secretos de armas nucleares.

Trata-se de uma grande ameaça ao regime de não proliferação, como visto na experiência do Paquistão, país que se valeu de uma rede clandestina para a aquisição legítima desses itens com uso duplo para o desenvolvimento de sua arma nuclear, como será observado neste capítulo. Poucos anos depois, na sequência da guerra do Iraque de 1991, essa ameaça foi novamente verificada quando inspetores da ONU depararam-se com instalações para desenvolvimento de armas nucleares que utilizavam diversas bombas a vácuo fabricadas pela Oerlikon Leybold Vacuum, uma firma alemã que fabricava itens de tecnologia a vácuo para aparelhos de ar-condicionado, televisores e aplicações automotivas $^{12}$.

O presente capítulo trará, assim, uma análise dos mecanismos complementares que conformam e robustecem o regime de não proliferação e as iniciativas pelo banimento das armas nucleares, pela forma de tratados já aprovados ou ainda em negociação, por resoluções inovadoras do Conselho de Segurança e pela iniciativa não institucional voluntariamente praticada por alguns Estados.

\subsection{Tratado de proibição completa de testes nucleares - CTBT}

$\mathrm{Na}$ análise feita sobre o TNP, um traço que foi mencionado como distintivo do tratado por propiciar elementos de reforço do aparato internacional dimensionado para se

Nuclear Orders. Tokyo: United Nations University, 2009, p. 223-224. É interessante lembrar que a descoberta do programa nuclear líbio, em 2004, como mencionado no capítulo 2 da segunda parte desta dissertação, apenas ocorreu pela interceptação de um navio alemão contendo itens destinados ao seu desenvolvimento.

12 FINLAY, Brian; GROSSMAN-VERMAAS, Rita. Technology Proliferation, Globalization and the Role of the United Nations. In: BOULDEN, James; THAKUR, Ramesh Chandra; WEISS, Thomas George (Coords.). The United Nations and Nuclear Orders. Tokyo: United Nations University, 2009, p. 200. 
obter o desarmamento nuclear, foi seu mecanismo de revisões periódicas, previsto no seu artigo VIII. As Conferências de Revisão previstas no artigo, realizadas a cada cinco anos contados de sua entrada em vigor revelaram-se importante instrumento pelo qual os Estados não nuclearmente armados puderam pressionar as potências nucleares para o cumprimento de sua obrigação de abdicarem de seus arsenais.

Especificamente, a conferência realizada depois de vinte cinco anos mostrou-se fundamental para fortalecer essa pressão, uma vez que, segundo o artigo X do TNP, naquela ocasião os Estados partes decidiriam sobre a extensão da vigência do tratado, inicialmente limitada a vinte e cinco anos. Como as potências nucleares pretendiam obter concordância quanto à extensão por período indefinido, os demais Estados encontravam-se numa extremamente favorável posição para imporem contrapartidas à aprovação daquela proposta.

Nesse contexto, "o principal elemento de barganha exigido pelos estados não nuclearmente armados em troca da extensão indefinida do TNP" ${ }^{13}$ foi o Tratado de Proibição Completa de Testes Nucleares ${ }^{14}$, cuja sigla é CTBT (Comprehensive Test Ban Treaty), assinado em 1996. Essa proposta foi acompanhada também do projeto para o estabelecimento de um tratado pela proibição de material físsil, que será analisada à frente. Considerava-se que, em conjunto, ambos os tratados representariam importantes mecanismos de integração do regime de controle nuclear, e providenciariam fundamentos para um futuro desarmamento nuclear ${ }^{15}$.

O principal efeito que justificava essa leitura do CTBT identificava nos testes nucleares um meio indispensável tanto para a manutenção quanto para a modernização dos arsenais nucleares. Por isso, como consta do preâmbulo do tratado

a suspensão de todas as explosões experimentais de armas nucleares e qualquer outra explosão nuclear, ao restringir o desenvolvimento e o aprimoramento qualitativo de armas nucleares, pondo fim ao

13 SAMPAIO, Maria Feliciana Nunes Ortigão de. O Tratado de Proibição Completa dos Testes Nucleares $(C T B T)$ : Perspectivas para sua entrada em vigor e para a atuação diplomática brasileira. Brasília: Alexandre de Gusmão, 2012, p. 27.

14 COMPREHENSIVE NUCLEAR-TEST-BAN TREATY. Disponível em: <http://www.ctbto.org/fileadmin/content/treaty/treaty_text.pdf>. Acesso em: 20 nov. 2014.

15 COMPREHENSIVE NUCLEAR-TEST-BAN TREATY (CTBT). Opened for Signature: 24 Sep. 1996. Site: NTI (The Nuclear Threat Initiative). Disponível em: <http://www.nti.org/treaties-andregimes/comprehensive-nuclear-test-ban-treaty-ctbt/>. Acesso em: 7 dez. 2014. 
desenvolvimento de novos tipos avançados de armas nucleares, constitui uma medida eficaz de desarmamento e não proliferação nucleares em tosos os seus aspectos.

Além disso, ao impedir a realização de qualquer explosão nuclear, o CTBT acarreta também importantíssimo efeito contrário à possibilidade do desvio de programas civis de energia nuclear para a produção de armamentos. Com efeito, com base no tratado foi criada uma organização que gerencia seu funcionamento e controla um complexo mecanismo de monitoramento global, dimensionado para detectar qualquer explosão nuclear no globo terrestre, importante obstáculo para evitar a transposição da barreira entre usos pacíficos e bélicos da energia nuclear ${ }^{16}$.

Adicionalmente, o CTBT foi muito festejado por constituir, finalmente, um elemento apto a romper com o caráter discriminatório estabelecido no TNP, e que poderia propiciar passos concretos rumo ao desarmamento. Nesse sentido, pela criação de regras idênticas a todos os países membros ao instituir a proibição universal de realização de quaisquer explosões nucleares, o mundo vislumbrou uma conquista que, a longo prazo, conforme não pudessem ser confiavelmente renovados e mantidos seus arsenais nucleares, promoveria o desarmamento nuclear mundial ${ }^{17}$. A experiência concreta, contudo, não comprovou, ao menos até agora, essas expectativas.

Apesar da recepção ampla que o tratado teve internacionalmente, contando, hoje, com 183 signatários e 162 ratificações ${ }^{18}$, mesmo passados quase vinte anos desde sua assinatura, ele ainda não entrou em vigor porque não foi atendida a condição imposta em seu artigo XIV, que prevê que o CTBT entrará em vigor no prazo de 180 dias contados da ratificação por parte de todos os Estados mencionados no anexo 2 do tratado.

No referido anexo 2, são listados 44 países que, seja por possuírem reconhecida capacidade nuclear, civil ou bélica, seja por serem considerados possíveis ameaças ao regime de não proliferação, devem ratificar sua adesão ao CTBT para que este possa entrar

16 SAMPAIO, Maria Feliciana Nunes Ortigão de. O Tratado de Proibição Completa dos Testes Nucleares $(C T B T)$ : Perspectivas para sua entrada em vigor e para a atuação diplomática brasileira. Brasília: Alexandre de Gusmão, 2012, p. 27.

17 Ibidem, p. 18.

18 COMPREHENSIVE NUCLEAR-TEST-BAN TREATY (CTBT). Opened for Signature: 24 Sep. 1996. Site: NTI (The Nuclear Threat Initiative). Disponível em: <http://www.nti.org/treaties-andregimes/comprehensive-nuclear-test-ban-treaty-ctbt/>. Acesso em: 7 dez. 2014. 
em vigor. Trata-se de uma condição realista e compreensível, porque dificilmente o tratado poderia ser considerado eficaz sem a participação dos Estados que mais se apresentem como possíveis descumpridores de suas obrigações centrais.

Desses Estados, até hoje, à exceção da Coreia do Norte, Congo, Índia e Paquistão, todos assinaram o tratado; cinco deles assinaram, mas não o ratificaram, a China, o Egito, o Irã, Israel e os EUA, sendo importante notar que os únicos países nuclearmente armados que não ratificaram sua adesão ao CTBT são a China e os EUA ${ }^{19}$. Esse quadro acaba, uma vez mais, apontando a postura dúbia das principais nações nucleares como um dado da realidade que apenas corrói o regime de não proliferação, já que, sinalizaram com o tratado para obterem a extensão do TNP, obtiveram-na e, quase duas décadas depois, ainda relutam em permitir que o CTBT entre em vigor.

Essa situação pendente, aliás, não causou tão somente a manutenção do quadro que já existia com base no TNP. Devido ao otimismo que marcava o período em que foi aprovado seu texto,

acreditava-se que entraria em vigor em dois ou três anos, razão pela qual se iniciou, de imediato, a construção do Sistema Internacional de Monitoramento e dos demais elementos do Regime Global de Verificação, instalando-se, em Viena, em 1997, a Comissão Preparatória da CTBTO (Organização para o Tratado de Proibição Completa de Testes Nucleares)" 20 .

Esse aparato institucional constitui um dos principais pilares do CTBT, uma vez que, independente dos compromissos nele assumidos, sua eficácia apenas se daria por meio de avançados meios de monitoramento e detecção de escala global capaz de identificar a realização de explosões nucleares. Aliás, essa característica é uma das razões que impediram qualquer avanço anterior em propostas de tratados contra testes nucleares, pelas limitações tecnológicas que existiam. O Regime Global de Verificação é composto por uma rede global de

19 CBTO. Status of Signature and Ratification. CTBTO preparatory commission for the comprehensive nuclear test-ban treaty organization. Disponível em: <http://www.ctbto.org/the-treaty/status-of-signatureand-ratification/>. Acesso em: 7 dez. 2014.

20 SAMPAIO, Maria Feliciana Nunes Ortigão de. O Tratado de Proibição Completa dos Testes Nucleares $(C T B T)$ : Perspectivas para sua entrada em vigor e para a atuação diplomática brasileira. Brasília: Alexandre de Gusmão, 2012, p. 20. 
mais de trezentas estações de sensoriamento em quatro tecnologias: sísmica, para monitorar testes subterrâneos, hidroacústica, para monitorar testes subaquáticos, infrassônica, para monitorar testes na atmosfera; e radionuclídea que, ao detectar e medir a presença de partículas radioativas, confirma a natureza nuclear de um evento ${ }^{21^{3}}$.

Ao ser antecipada a criação desse aparato tecnológico, consolidado e colocado em operação antes da entrada em vigor do CTBT, acabou sendo criada uma verdadeira anomalia porque, a rigor, formalmente esses organismos atuam sem base legal vigente, e, ainda assim, possuem plena capacidade funcional, havendo, inclusive, detectado a explosão nuclear realizada pela Coreia do Norte em 2006. Ainda mais grave, essa anomalia teve como resultado um aprofundamento do desequilíbrio discriminatório criado pelo TNP, já que sem a entrada em vigor do CTBT não houve qualquer limitação efetiva do direito das nações nucleares de realizarem testes atômicos, mas, em contrapartida, houve uma ampliação significativa do controle internacional contra novos proliferadores, sedimentando ainda mais o quadro internacional contra o qual os estados nucleares lutavam quando surgiu a proposta do $\mathrm{CTBT}^{22}$.

Depreende-se novamente do quanto exposto sobre essa descrição do CTBT que, assim como as demais iniciativas pelo controle da proliferação e pelo desarmamento nuclear, a luta entre as conquistas na busca desses objetivos é refreada pela relutância dos Estados nuclearmente armados.

Mesmo assim, não se pode desconsiderar o ganho representado pela criação do tratado e de sua organização e aparato técnico de monitoramento, mecanismos que já atuam no sentido de conter novas ameaças de proliferação num ambiente que, como descrito na introdução deste capítulo, apresenta instabilidades e riscos novos.

21 SAMPAIO, Maria Feliciana Nunes Ortigão de. O Tratado de Proibição Completa dos Testes Nucleares $(C T B T)$ : Perspectivas para sua entrada em vigor e para a atuação diplomática brasileira. Brasília: Alexandre de Gusmão, 2012, p. 65.

22 Ibidem, p. 20-21. 


\subsection{Convenção internacional pela supressão de atos de terrorismo nuclear}

Apesar dos sérios questionamentos que contrariam a possibilidade concreta de haver um ataque terrorista nuclear, como será analisado na quarta parte desta dissertação, esta é uma ameaça possível. O temor internacional contra esse risco, que escapa à possibilidade de controle pelos instrumentos já analisados, motivou a elaboração da Convenção Internacional para a Supressão de Atos de Terrorismo Nuclear ${ }^{23}$, aprovada em 2005.

A Convenção, como consta de seu preâmbulo, foi fruto dos trabalhos desenvolvidos pelo comitê ad hoc estabelecido pela Resolução 51/210 aprovada pela Assembleia Geral da ONU, em $1996^{24}$, que, reconhecendo a necessidade do fortalecimento do papel das Nações Unidas e das agências especializadas no combate ao terrorismo internacional, determinou a elaboração de uma convenção com essa finalidade para suplementar os instrumentos internacionais já existentes relacionados ao tema.

$\mathrm{O}$ art. 1 da convenção estabelece um glossário definindo diversos conceitos que servem de base para as provisões dos demais artigos, e o art. 2 contém descrição das condutas consideradas ilegais de acordo com ela, (i) como a posse de material radioativo com intenção de causar a morte ou sérios danos ao meio-ambiente, (ii) o uso de material radioativo com as mesmas intenções, (iii) o ataque contra instalações nucleares para a liberação de material radioativo, (iv) a realização ou ameaça de realização desses atos para chantagear pessoas físicas jurídicas, organizações ou estados a realizarem determinados atos.

Algumas polêmicas relacionadas à linguagem do art. 4 da convenção impediram que esta fosse rapidamente adotada. Especificamente, havia a preocupação dos Estados não nuclearmente armados, que se opunham à possibilidade de se considerar legítimo o uso de armas nucleares pelas forças militares das potências nucleares. Essa preocupação justificava-se porque, segundo os itens 2 e 4 desse artigo, as atividades das forças armadas durante conflitos armados, realizadas por forças militares no exercício de suas atribuições oficiais, eram explicitamente colocadas como fora do âmbito da convenção. O item 4 ia além ao claramente afirmar que a convenção não se relaciona, nem pode ser interpretada

23 UNITED NATIONS. International convention for the suppression of acts of Nuclear terrorism, 2005. Disponível em: <https://treaties.un.org/doc/db/Terrorism/english-18-15.pdf〉. Acesso em: 20 nov. 2014.

24 UNITED NATIONS. General Assembly. 17 Dec. 1997. Measures to eliminate international terrorism. Disponível em: <http://www.un.org/documents/ga/res/51/a51r210.htm〉. Acesso em: 20 nov. 2014. 
como se fosse relacionada, à questão da legalidade do uso ou da ameaça de uso de armas nucleares por Estados.

Os Estados não nuclearmente armados, já atentos para o risco de interpretações amplas e às vezes distorcidas pelas potências nucleares dos compromissos internacionais estabelecidos sobre a questão nuclear, não pretendiam criar qualquer chance de, ao aprovarem a convenção, legitimarem a possibilidade de uso ou ameaça de uso de armas nucleares. Esse impasse foi superado pela emenda efetuada sobre o artigo, estipulando que a convenção não poderia ser interpretada no sentido de reconhecer a legalidade do uso ou ameaça de uso de armas nucleares ${ }^{25}$.

A convenção foi, então, aprovada em 13 de abril de 2005, durante o plenário da $91^{\text {a }}$ reunião da Assembleia Geral pela resolução A/RES/59/29026, o primeiro tratado antiterrorista adotado desde os ataques de 11 de setembro de 2001. Atualmente, a convenção conta com 86 estados partes, e 56 signatários que ainda não a ratificaram.

As principais provisões da convenção podem ser assim elencadas ${ }^{27}$ :

- definição mais ampla de materiais e instalações nucleares abrangendo tanto aplicações militares quanto pacíficas;

- a criminalização do planejamento, da ameaça, ou da realização de atos de terrorismo nuclear, requerendo aos Estados que desenvolvam previsões legais domésticas criminalizando as condutas previstas na convenção;

- condições que definem a jurisdição dos Estados para punir essas ofensas;

- regras gerais para extradição e punição de indivíduos;

- requisição para os Estados adotarem todas as medidas necessárias para prevenir ou conter preparação de ofensas a serem praticadas tanto em seus territórios como fora deles.

25 UNITED NATIONS. International convention on the Suppression of Acts of Nuclear Terrorism. Opened for Signature: 14 Sep. 2005. Disponível em: <http://www.nti.org/treaties-and-regimes/internationalconvention-suppression-acts-nuclear-terrorism/>. Acesso em: $7 \mathrm{dez} .2014$.

26 UNITED NATIONS. UN Documents. Resolution adopted by the General Assembly. 13 April 2005. 59/290. International Convention for the Suppression of Acts of Nuclear terrorism. Disponível em: <http://www.un-documents.net/a59r290.htm>. Acesso em: 7 dez. 2014.

27 UNITED NATIONS. International convention for the suppression of acts of Nuclear terrorism, 2005. Disponível em: <https://treaties.un.org/doc/db/Terrorism/english-18-15.pdf〉. Acesso em: 20 nov. 2014. 
Essa última previsão possui um efeito muito relevante, já que representa um meio de punir Estados partes dessa convenção que não lutem contra movimentos terroristas localizados em seus territórios e que cometam ataques nela previstos. Trata-se de uma possível "ponte" que permite estabelecer a responsabilidade de Estados por eventuais atos terroristas cometidos por grupos atuantes dentro deles, às vezes com base em permissividade e negligência flagrantes, ultrapassando a impotência geralmente reconhecida de tratados preverem punição contra atos cometidos por grupos não estatais.

Em relação à interação dessa convenção com demais instrumentos do regime de não proliferação, é interessante destacar a previsão do art. 8, que prevê que os Estados, para prevenirem ofensas previstas na convenção, devem adotar todas as medidas para reforçar a proteção de materiais radioativos, de acordo com as recomendações e funções estabelecidas pela AIEA.

Essa previsão é de fundamental importância para conter a ameaça do terrorismo nuclear internacional, já que existem alguns registros de ataques contra instalações nucleares pacíficas, cujos objetivos podem variar da sua destruição até o roubo de combustível físsil para a produção clandestina de armas.

Em 2007, na África do Sul, quatro homens armados invadiram a instalação nuclear de Pelindaba, situada próximo à Pretória, local com estoque de centenas de urânio enriquecido no nível necessário para a produção de armamentos. De acordo com as autoridades, os criminosos superaram diversos mecanismos de segurança, indicando conhecimento do sistema existente. Eles permaneceram por aproximadamente 45 minutos dentro de uma das localidades mais protegidas da África do Sul, e, depois de uma troca de tiros, conseguiram escapar pela mesma maneira com que invadiram aquela instalação ${ }^{28}$. Mais recentemente, em meio à instabilidade regional causada pelo surgimento e desenvolvimento do grupo conhecido por Estado Islâmico do Iraque e do Levante, ou apenas por Estado Islâmico, autointitulado califado, com pretensão territorial na área

\footnotetext{
${ }^{28}$ ZENKO, Micah. A Nuclear Site is Breached. Washingtonpost.com. (Opinions), Washington, DC, 20 Dec. $2007 . \quad$ Disponível em: $\quad$ z<http://www.washingtonpost.com/wpdyn/content/article/2007/12/19/AR2007121901857.html>. Acesso em: 16 nov. 2014
} 
compreendida entre as fronteiras da Turquia, Síria e Iraque ${ }^{29}$, quando a cidade iraquiana de Mossul caiu sob o domínio desse grupo, em julho de 2014, foi noticiado o roubo de material nuclear de um centro de pesquisa universitário ${ }^{30}$.

Além disso, o art. 18 contém previsão explícita contra a proliferação nuclear ao estabelecer que materiais e equipamentos flagrados na posse de indivíduos e grupos terroristas, caso o flagrante ocorra por Estado que não esteja autorizado pelo TNP a possuir armas e dispositivos nucleares, deverão ser entregues o quanto antes para o controle da AIEA ou dos cinco Estados nuclearmente armados autorizados a recebê-los de acordo com as normas vigentes.

Como último registro, essa Convenção pela Supressão de Atos de Terrorismo Nuclear pode ser considerada complementar, ou, em certa medida, até suplantadora da Convenção Sobre Proteção Física de Material Nuclear ${ }^{31}$. Essa convenção foi assinada em 1980, e, até a aprovação da convenção contra terrorismo nuclear, era a única obrigação internacional na área da proteção física de material nuclear. Em 2005, foi realizada uma conferência diplomática para emendar a convenção, fortalecendo algumas de suas provisões, sendo interessante mencionar a previsão de cooperação internacional para adoção de medidas para rápida identificação e recuperação de material nuclear roubado, mitigação de efeitos radioativos consequentes de sabotagens e a prevenção e o combate de outras ofensas a elas relacionadas ${ }^{32}$.

\subsection{Tratados bilaterais de desarmamento}

Ao lado dos acordos multilaterais, há alguns tratados bilaterais que não poderiam ser ignorados na descrição do aparato internacional existente em relação à não proliferação e desarmamento nuclear. Basicamente, apenas há registros de iniciativas bilaterais de

29 PIPES, Daniel. Não há diferenças entre o EIIS e o EIIL. (p/ National Review Online. 12 set. 2014.) Disponível em: <http://pt.danielpipes.org/14939/eiis-eiil>. Acesso em: 23 set. 2014.

30 NICHOLS, Michelle. Iraq tells U.N. that 'terrorist groups' seized nuclear materials. Reuters edition US, 9 Jul. 2004. Disponível em: <http://www.reuters.com/article/2014/07/09/us-iraq-security-nuclearidUSKBNOFE2KT20140709>. Acesso em: 4 dez. 2014.

31 IAEA. Information Circular. Text of the convention on the physical protection of nuclear material. Nov. 1979. Disponível em: <http://www.iaea.org/sites/default/files/infcirc274.pdf〉. Acesso em: 10 nov. 2014.

32 IAEA. Convention on the physical protection of nuclear material. (Todos os documentos correlatos.) Disponível em: http://www.iaea.org/publications/documents/conventions/convention-physical-protectionnuclear-material>. Acesso em: 15 Nov. 2014. 
limitação e redução de armas nucleares entre os Estados Unidos e a Rússia, alguns deles datados do período em que ainda existia a União Soviética.

Existem várias iniciativas nesse sentido, tais como o SALT I, relacionado à limitação de armas estratégicas, assinado em 1972, expirado em 1977; SALT II, assinado em 1979, mas que nunca entrou em vigor; INF, relacionado à eliminação de forças intermediárias de ataque, assinado em 1987; START I, relacionado à redução de armas estratégicas, assinado em 1991; START II, assinado em 1993, mas que não entrou em vigor; SORT, relacionado à redução ofensiva de armas estratégicas, assinado em 2002, em vigor desde 2012.

Há o entendimento de que essas iniciativas decorreram de um clima da distensão no antagonismo bipolar que marcou a Guerra Fria, especialmente a partir de 1985, quando Reagan e Gorbachev lideraram conjuntamente uma busca por um novo padrão de relacionamento entre os dois governos, sendo que dois anos depois foi assinado o acordo sobre forças nucleares intermediárias (INF), que eliminava toda uma nova classe de mísseis que poderiam ser utilizados em qualquer direção através da Europa ${ }^{33}$.

Apesar da retórica positiva de uma redução e limitação de arsenais atômicos, medidas que podem ser consideradas como precursoras para o cumprimento da obrigação de desarmamento prevista no TNP, esses acordos, invariavelmente, atacam armamentos obsoletos, ultrapassados, ou que, por outras razões estratégicas, não são mais vistos como essenciais.

Utiliza-se, assim, esses acordos para propagar medidas de desarmamento que, na realidade, são inócuas para efetuar alguma alteração significativa no tabuleiro internacional atômico. Tanto é assim que, mesmo nos limites estabelecidos nesses acordos de redução de armas estratégicas, a capacidade destrutiva mantida pelas potências era suficiente para arruinar praticamente todas as cidades da América do Norte e da Eurásia ${ }^{34}$.

Apesar dessa realidade, verifica-se que, do mesmo modo como qualquer mínimo abalo contra o regime estabelecido no TNP é capaz de gerar sérios distúrbios contra a confiança internacional sobre sua funcionalidade e eficácia, descumprimentos desses

33 BUNDY, McGeorge; CROWE JR., William J.; DRELL, Sidney D. Reducing Nuclear Danger - The Road Away from the Brink. New York: Council on Foreign Relations Press, 1993, p. 25, tradução livre do original em inglês. Ver ainda: Committee on International /Security and Arms Control - National Academy of Sciences. The Future of the U.S. - Soviet Nuclear Relationship. Washington: National Academy, 1991, p. vii.

34 ZUCKERMAN, Solly. Nuclear Illusion and Reality. New York: The Viking, 1982, p. 119. 
acordos são capazes de acirrar rapidamente as relações bilaterais, ameaçando-as com desestabilização mesmo num contexto em que não faz mais sentido pensar-se na confrontação bipolar da Guerra Fria.

Tome-se, por exemplo, o acordo INF, assinado em 1987, pelo qual os Estados Unidos e a então URSS decidiram eliminar seus respectivos mísseis balísticos com alcance entre 500 e 5.500 quilômetros, resultando na destruição de um total de 2.692 mísseis ${ }^{35}$. Em outubro de 2014, houve denúncias de parte a parte em relação à violação desse acordo, sendo que, conforme os Estados Unidos, a Rússia o teria violado pelo lançamento de um míssil de cruzeiro com alcance identificado nos limites do acordo, ao que a Rússia teria replicado denunciando os Estados Unidos pelo teste de um sistema de defesa contra mísseis balísticos ${ }^{36}$. Na sequência desses eventos houve uma série de troca de acusações de lado a lado, numa rápida exacerbação de ameaças inclusive sobre a manutenção de outros acordos bilaterais.

\subsection{Projetos de tratados}

Adicionalmente aos tratados e convenções já analisados, existem projetos de novas iniciativas normativas que, mesmo não tendo ainda sido aprovadas, e que podem nem vir a ser, merecem uma rápida menção pelo significativo potencial que possuem para o fortalecimento da construção do ideal do desarmamento nuclear completo.

\subsubsection{O tratado contra materiais físseis (FCMT)}

No mesmo contexto internacional que propiciou a assinatura do CTBT já analisado neste capítulo, foi também aventada uma iniciativa que teria papel muito importante no processo do desarmamento nuclear: o banimento de materiais físseis não destinados ao uso pacífico da energia nuclear. Essa meta foi tratada pela Conferência do Desarmamento ${ }^{37}$,

35 THE INTERMEDIATE-RANGE NUCLEAR FORCES (INF) Treaty at a Glance. Press Contacts: Kelsey Davenport and Daryl Kimball. (Posted 23 May 2014.) Arms Control Association. Disponível em: <http://www.armscontrol.org/factsheets/INFtreaty>. Acesso em: 13 dez. 2014.

36 Armas nucleares voltam à pauta. DefesaNet, 31 out. 2014. Disponível em: <http://www.defesanet.com.br/nuclear/noticia/17287/Armas-nucleares-voltam-a-pauta/>. Acesso em: 30 nov. 2014.

37 Fórum internacional focado em iniciativas pelo desarmamento multilateral. Apesar de se reportar à Assembleia Geral da ONU, possui seus próprios regulamentos, tendo sido responsável pelos principais acordos de desarmamento, como o TNP, a Convenção sobre Armas Químicas, Convenção de Armas 
que elaborou o projeto do Tratado Contra Materiais Físseis, o qual, ao lado do CTBT, representa componente relevante para a obtenção do desarmamento nuclear ${ }^{38}$.

A relevância desse projeto verifica-se porque, se aprovado, propiciará um banimento global do material físsil necessário para a produção de novos armamentos nucleares. Ou seja: ainda que mantida a relutância contra o desarmamento, haverá, forçosamente, um limite claro para a produção futura de arsenais, determinado pela quantidade de combustível nuclear existente.

O projeto segue atualmente em discussão, e, como ainda não foi definido seu escopo final, não se sabe se o tratado determinará também o banimento dos estoques já existentes de material físsil, meta defendida por alguns estados e que representa uma das principais pendências polêmicas que impedem o avanço para sua aprovação. Caso aceita a proposta de que sejam incluídos os estoques existentes, a limitação dos arsenais mencionada no parágrafo acima seria ainda mais drástica, reduzida apenas às armas já existentes, porque não haverá mais combustível nuclear disponível para a fabricação de novos armamentos.

\subsubsection{Convenção sobre armas nucleares (NWC)}

Em abril de 1997, um grupo de cientistas, juristas, físicos, diplomatas e especialistas em desarmamento elaborou um modelo de uma Convenção de Armas Nucleares, submetida pela Costa Rica às Nações Unidas sob a forma de um documento para discussão ${ }^{39}$. A versão revisada desse projeto foi submetida conjuntamente pela Costa Rica e pela Malásia, baseada nas convenções relativas a armas químicas e biológicas, e seria suplementar aos tratados multilaterais já existentes sobre o tema, o TNP e o CTBT.

De acordo com esse projeto, todos os Estados seriam proibidos de participar no desenvolvimento, teste, produção, armazenamento, transferência, uso e ameaça de uso de armas nucleares. Além disso, aqueles Estados que possuem armas nucleares seriam

Biológicas e Tóxicas e o CTBT. Cf. <http://www.nti.org/glossary/\#conference-disarmament>. Acesso em: 10 dez. 2014.

38 COMPREHENSIVE NUCLEAR-TEST-BAN TREATY (CTBT). Opened for Signature: 24 Sep. 1996. Site: NTI (The Nuclear Threat Initiative). Disponível em: <http://www.nti.org/treaties-andregimes/comprehensive-nuclear-test-ban-treaty-ctbt/>. Acesso em: 7 dez. 2014.

39 UNITED NATIONS. General Assembly. 17 Nov. 1997. General and complete disarmament. Letter dated 31 October 1997 from the Chargé d'affaires of the a.i Permanent Mission of Costa Rica to the United Nations addressed to the Secretary General. Disponível em: <http://www.un.org/ga/search/view_doc.asp?symbol=A\%2FC.1\%2F52\%2F7\&Submit=Search \&Lang=E>. Acesso em: 7 dez. 2014. 
obrigados a destruir seus arsenais por meio das seguintes etapas: retirando seus arsenais de estado de alerta, removendo as armas alocadas pelo mundo, removendo as armas dos vetores necessários para seu uso, desmantelando as ogivas nucleares, removendo e desfigurando os silos e submetendo o material físsil ao controle internacional.

Segundo o modelo da NWC, seria ainda estabelecida uma Agência pela Proibição de Armas Nucleares, que teria a incumbência de verificar a observância das normas entre os estados membros, assegurar seu cumprimento, tomar decisões e providenciar um fórum para consultas e cooperação entre os estados partes, sendo que eventuais disputas seriam levadas à Corte Internacional de Justiça com base no mútuo consentimento dos estados partes. Por constituir uma iniciativa que atenderia de modo completo aos anseios pelo estabelecimento de medidas concretas que possibilitariam o desarmamento nuclear universal, naturalmente não há apoio unânime dos estados, especialmente das potências nucleares. Nos trabalhos preparatórios para a Conferência de Revisão do TNP prevista para ocorrer em 2015, vários estados não nuclearmente armados assumiram uma postura bastante agressiva pela adoção de medidas que, mesmo sem a força da NWC, reforçariam os meios de se obter, futuramente, o desarmamento nuclear ${ }^{40}$.

Finalizada a análise das iniciativas normativas existentes em relação à questão nuclear, é importante verificar medidas não normativas, tanto resoluções do Conselho de Segurança, quanto medidas adotadas fora do escopo institucional da ONU.

\subsection{A Resolução 1540 do Conselho de Segurança da ONU}

Como observado no capítulo 2 desta segunda parte do trabalho, a partir das experiências verificadas ao longo da década de 1990 - especialmente a descoberta do programa secreto iraquiano, o estabelecimento da Índia como nação nuclearmente armada, o desenvolvimento nuclear paquistanês fomentado pela rede clandestina mantida por Abdul Qadeer Khan e a ameaça imposta pelo terrorismo internacional -, o Conselho de Segurança passou a adotar uma postura propositiva em relação ao tema da proliferação nuclear, principalmente ao alterar o paradigma de suas resoluções, invertendo o ônus da prova para que os suspeitos de violarem as normas internacionais tivessem de adotar

40 <http://www.nti.org/treaties-and-regimes/proposed-nuclear-weapons-convention-nwc/>. Acesso em: 7 dez. 2014. 
postura de transparência integral de suas iniciativas voltadas à energia nuclear para evitar a aplicação de sanções e embargos econômicos.

Entretanto, essa iniciativa do Conselho de Segurança era limitada, à medida que estados não situados dentro do regime estabelecido pelo TNP estariam, de certo modo, imunes à alegação de violação de normas, já que não estariam submetidos às obrigações previstas no tratado.

Essa limitação foi atacada pela Resolução $1540^{41}$, aprovada em 2004 , pela qual o Conselho, baseado nas preocupações sobre terrorismo nuclear, determinou um conjunto mínimo de padrões para todos os estados membros da ONU com relação a armas nucleares, químicas e biológicas, um desenvolvimento jurídico internacional crítico com sérias implicações ao determinar, por exemplo, a estados soberanos que estabelecessem legislações específicas contra a proliferação nuclear ${ }^{42}$.

De acordo com essa resolução, o Conselho decidiu, principalmente, que:

- todos os estados devem evitar providenciar qualquer forma de apoio a atores não estatais que busquem desenvolver, adquirir, fabricar, possuir, transportar ou transferir armas nucleares, químicas ou biológicas;

- todos os estados, de acordo com seus procedimentos nacionais, devem adotar e aplicar leis apropriadas para proibir que qualquer ator não estatal produza, adquira, possua, desenvolva ou transporte essas armas;

- todos os estados devem adotar medidas domésticas efetivas de controle para prevenir a proliferação de armas nucleares, químicas ou biológicas, assim como detectar, evitar, prevenir e combater seu tráfico ilícito;

- de acordo com a regra 28 de seu regulamento provisório de procedimento, estabeleceria, por um período não superior a dois anos, um Comitê do Conselho

41 UNITED NATIONS. Resolution 154 (2004). Adopted by the Security Council at its 4956th meeting, on 28 April 2004. Disponível em: <http://www.un.org/en/ga/search/view_doc.asp?symbol=S/RES/1540\%20(2004)>. Acesso em: 20 nov. 2014.

42 BOULDEN, James; THAKUR, Ramesh Chandra; WEISS, Thomas George. The United Nations and Nuclear Orders: Context, Foundations, Actors, Tools, and Future Prospects. In: United Nations and Nuclear Orders. Tokyio: United Nations University, 2009, p. 13. (Coords.). The 
de Segurança, responsável para gerir e monitorar o cumprimento das obrigações estabelecidas na resolução ${ }^{43}$.

Essa resolução, que atua complementarmente às resoluções $1267^{44}$ e $1373^{45}$, as quais determinam sanções financeiras, embargos e restrições a indivíduos associados a redes terroristas, é relevante porque, dado seu caráter vinculante, impõe-se sobre todos os estados membros das Nações Unidas, mesmo aqueles que não são partes da convenção internacional para a supressão de atos de terrorismo nuclear, ou até do TNP, ambos instrumentos que impõem obrigações similares às determinadas por esta resolução.

Indubitavelmente, essa característica da resolução incrementa sobremaneira o regime de não proliferação e segurança nuclear, representando importante meio de suprir as falhas e limitações verificadas nos tratados e instituições já analisados, ao impor a todos os estados, independente dos compromissos assumidos internacionalmente, o respeito a um padrão rígido de conduta, inclusive com implicações em seus próprios ordenamentos internos.

Por outro lado, essa resolução é também motivo de muitas críticas. Primeiramente porque ela é fruto de um sistema muitas vezes objetado por não ser transparente nem democrático. Nesse sentido, “o fato de o Conselho, que não é um órgão representativo de todas as nações, projetar um poder legislativo tão vasto, ao ponto de tornar tratados mandatórios mesmo a estados que não os tenham adotado, é altamente negativo diante de demandas modernas por transparência e pela maior participação de todos os estados em relação aos temas internacionais" ${ }^{46}$.

43 Esse comitê, alegadamente estabelecido em caráter provisório, teve seu mandato renovado sucessivamente até 2021, com a ampliação de seus aparatos de atuação por meio das resoluções 1977 (UNITED NATIONS. Resolution 1977 (2011). Adopted by the Security Council at its 6518th meeting, on 20 April 2011. Disponível em: <http://www.un.org/en/ga/search/view_doc.asp?symbol=S/RES/1977\%20(2011)> Acesso em: 27 dez. 2014.) e 2055 (UNITED NATIONS. Resolution 2055 (2012). Adopted by the Security Council at its 6795th meeting, on 29 June $2012 . \quad$ Disponível em: <http://www.securitycouncilreport.org/atf/cf/\%7B65BFCF9B-6D27-4E9C-8CD3CF6E4FF96FF9\%7D/s_res_2055.pdf>. Acesso em: 6 dez. 2014.).

44 UNITED NATIONS. Resolution 1267 (1999). Adopted by the Security Council at its 4051st meeting on 15 October $1999 . \quad$ Disponível em: <http://www.un.org/ga/search/view_doc.asp?symbol=S/RES/1267(1999)>. Acesso em: 6 dez. 2014.

45 UNITED NATIONS. Resolution 1373 (2001). Adopted by the Security Council at its 4385 th meeting, on 28 September 2001. Disponível em: http://daccess-ddsny.un.org/doc/UNDOC/GEN/N01/557/43/PDF/N0155743.pdf?OpenElement. Acesso em: 6 dez. 2014.

46 LOUKA, Ellie. Nuclear Weapons, Justice and the Law. Cheltenham: Edward Elgar, 2011, p. 237. 
Ainda mais preocupante era a percepção de que qualquer tentativa de penalizar algum estado com base nessa resolução implicaria aplicação de sanções pela violação de tratados explicitamente rejeitados, o que constituiria uma guinada muito revolucionária das normas universalmente aceitas de soberania nacional, circunstância que traria grande temor à grande maioria dos estados 47 .

Embora se reconheça, no direito internacional contemporâneo, que não mais se pode defender o conceito da soberania irrestrita, que deve ser pelo interesse geral da comunidade internacional $^{48}$, há limites para essa relativização, especialmente quando essa medida do Conselho de Segurança é incongruente com outras pendências relevantíssimas no que toca à agenda da não proliferação e desarmamento nuclear.

Com efeito, considerando que o Conselho de Segurança tem, como seus membros permanentes, as únicas nações nuclearmente armadas de acordo com o TNP, salta aos olhos a enorme discrepância na conduta dessas mesmas nações no que tange à questão nuclear. Como já observado, em diversos marcos internacionais seu comportamento tem sido manifestamente contrário ao reforço das iniciativas internacionais em prol da não proliferação e do desarmamento nuclear.

Vale citar, neste particular, o descumprimento contumaz da obrigação de se desarmarem de acordo com o TNP, o desrespeito às zonas livres de armas nucleares pela imposição de ressalvas ou mesmo recusa em assinar os protocolos de adesão, a inconsistência decorrente da seletividade na aplicação de sanções apenas contra determinados estados considerados proliferadores, desrespeito a garantias de segurança sinalizadas para que estados abdicassem de programas nucleares.

Entretanto, apesar dessa postura evasiva e contrária ao objetivo do desarmamento nuclear, essas potências exerceram seu poder político de modo intransigente no âmbito do Conselho de Segurança, culminando na aprovação de uma resolução que atende exclusivamente aos seus interesses. Enquanto persistem com sua postura vaga, compelem

47 BOULDEN, James; THAKUR, Ramesh Chandra; WEISS, Thomas George. The United Nations and Nuclear Orders: Context, Foundations, Actors, Tools, and Future Prospects. In: (Coords.). The United Nations and Nuclear Orders. Tokyio: United Nations University, 2009, p. 13-16. Para uma crítica sobre os limites de atuação do Conselho de Segurança, cf. SALIBA, Aziz Tuffi. Conselho de Segurança da ONU - sanções e limites jurídicos. Curitiba: Juruá, 2008.

48 SALIBA, op. cit., p. 97. 
mandatoriamente toda a sociedade internacional a uma série de condutas que elevam o padrão da segurança internacional ao nível que elas consideram adequado.

Essas questões apenas tendem a reforçar as críticas contra o sistema capitaneado pelas nações nucleares, prestando-se como incentivo a um número cada vez mais amplo de estados insatisfeitos contra a perenização do caráter discriminatório, pouco transparente, ideologicamente seletivo e inconsistente que marca o regime até hoje constituído pelo tripé TNP-AIEA-Conselho de Segurança.

Outro aspecto que também permite considerar essa resolução inadequada e cujas obrigações são de difícil cumprimento por todos os estados é o autocentrismo que, aparentemente, encampou sua formulação. Para um país com desenvolvido aparato institucional, político e econômico, é plenamente factível falar-se em reforço de fronteiras e aprimoramento de mecanismos de segurança, defesa e controle contra o risco da proliferação nuclear.

Mas as obrigações impostas pela Resolução 1540 destinam-se, principalmente, aos países em desenvolvimento, cuja imensa maioria "enfrenta dificuldades muito maiores para a prevenção da proliferação. Não apenas esses países são alvos mais fáceis para redes criminosas com aspirações de proliferação, mas muitos deles enfrentam dificuldades sistêmicas econômicas e sociais, com sérios reflexos em seus orçamentos nacionais. Convencer seus governos a investir mais recursos em medidas contra a proliferação nuclear, em cumprimento das obrigações elencadas na resolução ora comentada, enquanto sua infraestrutura sofre com grave negligência, não é tarefa fácil, ou sequer razoável" ${ }^{49}$.

Assim, os membros da ONU deveriam ter adotado uma estratégia distinta para atingir resultados mais positivos, como a cooperação com aqueles países para seu reforço institucional, incremento de seguranças fronteiriças, construção de capacidade para um enfrentamento mais adequado de seus problemas sociais etc. Há pouco sentido em exigir a alocação de recursos para esboçar novas medidas de controle de exportação em um estado

49 FINLAY, Brian; GROSSMAN-VERMAAS, Rita. Technology Proliferation, Globalization and the Role of the United Nations. In: BOULDEN, James; THAKUR, Ramesh Chandra; WEISS, Thomas George (Coords.). The United Nations and Nuclear Orders. Tokyo: United Nations University, 2009, p. 201, tradução livre do original em inglês. 
com capacidade judicial e legal limitada que não possui meios sequer de controlar suas fronteiras ou punir transgressões ${ }^{50}$.

A análise dessa Resolução acaba tangenciando outro foco de atuação do regime de não proliferação, que se dá justamente pela formação de grupos de controle de exportação de materiais e equipamentos que podem ser desviados para o desenvolvimento de programas nucleares clandestinos.

\subsection{Iniciativas institucionais não formais contra a proliferação nuclear}

\subsubsection{Controle de exportações}

Conforme verificado neste capítulo, atualmente há um crescente temor internacional diante da expectativa da ampliação do número de nações que venham a controlar o ciclo nuclear, dominando tecnologicamente os meios para utilizar a energia atômica para fins pacíficos e militares. Essa faceta contemporânea impõe riscos adicionais contra o regime de não proliferação, uma vez que tende a se tornar mais difícil discriminar importações de itens para programas nucleares pacíficos, daquelas importações de itens com usos duplos com objetivo deliberado de desenvolvimento de programas bélicos clandestinos.

As estratégias normalmente adotadas para confrontar esse temor focam a recusa da transferência de tecnologia, no controle de exportações, no fortalecimento de salvaguardas, sanções etc. Contudo, a ausência de uniformidade nessas restrições propicia a grupos criminosos e estados interessados na proliferação nuclear um verdadeiro 'bazar' no qual podem escolher onde encontram condições mais propícias para desenvolverem suas atividades e adquirirem material, equipamentos e tecnologia para atingirem seus objetivos ilícitos 51 .

Essa restrição de exportações, ademais, é dificultada pela pressão financeira que acarreta sobre os governos, que se veem perdendo os frutos de transações internacionais substanciosas, confrontando interesses de suas relações tanto com setores privados quanto

\footnotetext{
${ }^{50}$ FINLAY, Brian; GROSSMAN-VERMAAS, Rita. Technology Proliferation, Globalization and the Role of the United Nations. In: BOULDEN, James; THAKUR, Ramesh Chandra; WEISS, Thomas George (Coords.). The United Nations and Nuclear Orders. Tokyo: United Nations University, 2009, p. 202-204.

51 Ibidem, p. 197-199.
} 
com o mundo em desenvolvimento ${ }^{52}$. Ainda a complicar mais essa circunstância, caso algum estado adote medidas mais restritivas do que outros países exportadores, ele acaba se tornando menos competitivo no comércio internacional, agravando ainda mais essa pressão financeira ${ }^{53}$.

A maneira identificada pelos estados para lidar com esses obstáculos foi por meio do estabelecimento de cartéis internacionais de exportação, os quais definem padrões mínimos a serem seguidos para a seleção de países aptos a adquirirem itens sensíveis em relação à proliferação nuclear, assim como quais itens devem ser submetidos a esse controle internacional. Uma complexidade adicional para o bom funcionamento desses cartéis é que sua meta é a segurança internacional, sendo difícil obter a concordância entre seus membros, que tende a ser mais fácil quando os objetivos se restringem a lucros financeiros ${ }^{54}$.

Vale o registro de dois desses cartéis principais: o Comitê Zangger, constituído em 1971 para definir as regras para aplicação do controle de exportação previsto no TNP, e o Grupo de Fornecedores Nucleares (NSG), "composto por 31 Estados fornecedores nucleares, entre eles o Brasil, que se formou em 1975, com sua primeira reunião em Londres, de que decorre sua segunda denominação, o Grupo de Londres" 55.

Em relação às regras de funcionamento do NSG, é interessante destacar que os estados que neguem exportação de itens de duplo uso, materiais ou equipamentos, para estados considerados ameaças contra o regime de não proliferação, devem notificar imediatamente todos os outros estados membros do cartel sobre a negativa e seus fundamentos. Quaisquer outros estados membros não estão autorizados a aprovar exportações àquele mesmo estado sem antes consultar o estado membro do NSG que se recusou a efetuar a exportação em primeiro lugar ${ }^{56}$.

Depreende-se dessa regra que o compartilhamento de informações torna-se vital para o bom funcionamento desses cartéis, medida de cooperação indispensável para suplantar

52 FINLAY, Brian; GROSSMAN-VERMAAS, Rita. Technology Proliferation, Globalization and the Role of the United Nations. In: BOULDEN, James; THAKUR, Ramesh Chandra; WEISS, Thomas George (Coords.). The United Nations and Nuclear Orders. Tokyo: United Nations University, 2009, p. 200.

53 LOUKA, Ellie. Nuclear Weapons, Justice and the Law. Cheltenham: Edward Elgar, 2011, p. 123.

54 Ibidem, p. 123-129.

55 MORE, Rodrigo Fernandes. O desarmamento no sistema de segurança coletiva da ONU. 2005. Tese (Doutorado) - Faculdade de Direito, Universidade de São Paulo, São Paulo, 2002, p. 82.

56 LOUKA, op. cit, p. 125. 
riscos, ao mesmo tempo em que se define compatibilização das respectivas políticas nacionais de exportações, essencial para construção de um sistema internacional eficaz de controle de exportações.

Com o passar do tempo, especialmente a partir dos anos 1990, mais empresas, situadas em mais países, passaram a deter controle tecnológico que as habilitava a produzir itens de duplo uso relacionados à tecnologia nuclear. Concomitantemente, verificou-se, no mesmo período, um aumento no número de países institucionalmente frágeis que se apresentavam como grandes atrativos para a proliferação nuclear, por meio de uma rede clandestina que se valia de transações internacionais situadas no limiar da ilegalidade, muito mais difíceis de identificar e controlar ${ }^{57}$.

O melhor exemplo concreto desse risco se verificou no modo como foi desenvolvido o programa nuclear do Paquistão. O país realizou seu primeiro teste nuclear em 1998, na sequência dos testes indianos. Contudo, toda a rede em que se baseou o desenvolvimento nuclear paquistanês apenas foi revelada anos depois, quando, em janeiro de 2004, agentes norte-americanos interceptaram um navio alemão, o BBC China, que transportava peças para um programa de produção de armas nucleares na Líbia. Em seguida, este país renunciou às suas ambições nucleares e denunciou o Paquistão - e especificamente o Laboratório de Pesquisas Khan - como o fornecedor do que seria um programa novo e completo de armas nucleares ${ }^{58}$.

Esse laboratório de pesquisas era presidido por Abdul Qadeer Khan, que teve seus estudos realizados na Europa para se tornar, em 1972, Ph.D. em física nuclear, indo trabalhar na empresa FDO - Fysich Dynamisch Onderzoek. Essa empresa era uma fornecedora holandesa de itens de enriquecimento de urânio para a URENCO, consórcio formado por Alemanha, Holanda e Reino Unido, submetido aos controles da EURATOM, já observados anteriormente.

57 FINLAY, Brian; GROSSMAN-VERMAAS, Rita. Technology Proliferation, Globalization and the Role of the United Nations. In: BOULDEN, James; THAKUR, Ramesh Chandra; WEISS, Thomas George (Coords.). The United Nations and Nuclear Orders. Tokyo: United Nations University, 2009, p. 197-199. Para lidar com essa circunstância, aventa-se a ideia de condicionar a continuidade dessas exportações à adesão, pelos adquirentes de material e equipamentos de duplo uso, ao Protocolo Adicional de 1997 ao sistema de salvaguardas estabelecido pela AIEA, Cf. LOUKA, Ellie. Nuclear Weapons, Justice and the Law. Cheltenham: Edward Elgar, 2011, p. 128.

58 LANGEWIESCHE, William. O bazar atômico - a escalada do poderio nuclear. Tradução de José Viegas. São Paulo: Companhia das Letras, 2007, p. 82. 
Os itens produzidos pela empresa tinham finalidade pacífica, porém eram itens de uso duplo, propiciando que Khan se apoderasse do conhecimento tecnológico e, aproveitando-se do livre acesso a informações, instalações, lista de fornecedores etc., pudesse fomentar todo o programa nuclear paquistanês sem qualquer alarde. O elemento que faltava era o apoio governamental para o financiamento da empreitada, o que foi facilitado pela motivação representada pelos avanços da rival Índia nessa questão ${ }^{59}$.

O grande aspecto inovador do plano de Khan foi se aproveitar justamente de uma rede de fornecedores de itens de uso duplo, localizados em países variados, dificultando o estabelecimento de qualquer conexão que pudesse suscitar quaisquer suspeitas sobre o que de fato ocorrida no Paquistão. O êxito desse projeto decorreu, em grande parte, desse método de obtenção de suprimentos discreto e especificamente designado para atender as necessidades técnicas que existiam, valendo notar que a maior parte dos fornecedores se localizava na Europa, inclusive em estados membros do NSG, os quais, presumivelmente, possuíam um sistema desenvolvido de controle de exportações ${ }^{60}$.

Um aspecto adicional que propiciou o êxito da rede fomentada por Khan foi um ressentimento verificado por diversos países contra os Estados Unidos e sua postura na questão nuclear, geralmente marcada por unilateralismo e intransigência. Esse comportamento das principais potências nucleares gera insatisfação não apenas em países em desenvolvimento, ou nações não alinhadas, mas em todos aqueles que se sentem discriminados pelo regime vigente.

Esse ressentimento determinou que os apelos norte-americanos para o reforço do controle de exportações fossem ignorados. “Os alemães estavam cada vez mais rebeldes. Refletindo uma atitude comum na Europa, eles se ressentiam do poder desproporcional dos Estados Unidos e suspeitavam que os americanos quisessem usar a questão da não proliferação para controlar o mercado livre mundial de combustíveis nucleares pacíficos" 61.

A corroborar essa falta de cooperação europeia, paradoxal porque ela própria se vê ameaçada pela proliferação nuclear, anos depois se teve notícia de que a Suíça havia

59 LANGEWIESCHE, William. O bazar atômico - a escalada do poderio nuclear. Tradução de José Viegas. São Paulo: Companhia das Letras, 2007, p. 90 e ss.

60 LOUKA, Ellie. Nuclear Weapons, Justice and the Law. Cheltenham: Edward Elgar, 2011, p. 234.

61 LANGEWIESCHE, op. cit., p. 122-123. 
reunido documentos relevantes sobre o projeto paquistanês, o qual teve a colaboração de alguns indivíduos de nacionalidade Suíça. Estranhamente, o país destruiu os documentos, prejudicando o esclarecimento de maiores detalhes da rede clandestina de Khan, sob a frágil alegação de que temia que os mesmos pudessem cair nas mãos de organizações terroristas que poderiam utilizá-los para desenvolvimento de redes similares ${ }^{62}$.

As graves consequências do ambiente que se revelou permissivo para a investida paquistanesa acabaram sensibilizando os países a reverem seus controles na área de exportação de materiais e itens de uso duplo, ao mesmo tempo em que se ampliou a fiscalização internacional sobre essas atividades. Vale destacar, confirmando essas alterações, a punição de três milhões de dólares americanos aplicada, em 2013, contra a empresa nuclear Industry Huaxing Construction Co. Ltd., por ter sido condenada nos Estados Unidos pela violação de normas de controle de exportações, a primeira dessas sanções de que se teve notícia na história ${ }^{63}$.

Verificada a quase totalidade dos acordos, convenções, tratados e resoluções aprovadas pelos órgãos máximos do sistema da ONU, emerge uma mesma marca comum a todos eles, qual seja, a permanência de limitações e inadequações para o confronto efetivo dos riscos postos contra o regime de não proliferação nuclear. Essas fragilidades decorrem tanto da dificuldade de serem estabelecidas iniciativas suficientemente desenvolvidas para lidar com as ameaças, quanto pelo comportamento dos estados, especialmente das nações nuclearmente armadas, que acabam minando as bases para que aquelas medidas possam atingir suas finalidades.

Essa circunstância impulsionou os estados a criarem mecanismos parainstitucionais, não formalmente organizados em tratados ou organismos internacionais, para lidarem com essas ameaças. A seguir serão analisadas algumas dessas principais iniciativas.

62 CRAIL, Peter. Swiss Destroy Key A.Q. Khan Evidence. Posted: Aug. 7, 2008. Arms Control Association. Disponível em: <http://www.armscontrol.org/act/2008_07-08/Swiss>. Acesso em: 18 nov. 2014.

63 PLOEGER, Patrick; SOMSEN, Marnix; LAMP, Roan. Worldwide: Export Control And Sanctions. 15 Feb. 2013. Mondaq connecting knowledge and people (site), Disponível em: <http://www.mondaq.com/x/221856/Export+controls+Trade+Investment+Sanctions/Export+Control +And+Sanctions\&email_access=on>. Acesso em: 21/06/2013. 


\subsubsection{Iniciativas parainstitucionais contra a proliferação nuclear}

\subsubsection{Proliferation Security Initiative (PSI)}

Como antecipado, identificando que o cenário internacional permanece insuficiente para atender de modo adequado aos anseios relacionados a meios mais efetivos de conter a proliferação nuclear, os estados foram compelidos a adotar medidas situadas fora do âmbito normativo e institucional usualmente reconhecido como legítimo para atuar em prol dessa meta.

Uma das iniciativas mais emblemáticas consequentes do reconhecimento dessa ineficácia do regime jurídico-institucional contra o risco da proliferação nuclear é conhecida como Proliferation Security Initiative, ou Iniciativa pela Segurança contra a Proliferação. Trata-se de

um esforço global para interromper o tráfico internacional de armas de destruição em massa, seus meios de disparo e materiais a elas relacionados, criado pelos EUA a partir de uma estratégia nacional que reconhece a necessidade de instrumentos mais robustos para conter a proliferação e identifica a interdição como uma área de foco mais importante ${ }^{64}$.

Segundo trabalho desenvolvido sob os auspícios do Instituto Internacional de Pesquisa da Paz de Estocolmo (Sipri - Stockholm International Peace Research Institute ${ }^{65}$ ), de autoria de Christer Ahlström, a PSI foi elaborada na sequência dos ataques de 11 de setembro de 2001, como consequência da percepção da necessidade de serem adotadas medidas mais robustas contra proliferadores de armas nucleares. Uma dessas medidas foi concebida como a interceptação de bens e equipamentos tecnológicos em trânsito, havendo os Estados Unidos destacado que se tratava de uma parte crítica de sua estratégia no combate contra armas de destruição em massa e seus mecanismos de disparo.

Ainda segundo o autor, havendo as autoridades americanas identificado limites impostos pelo direito internacional para esse tipo de conduta, foi formulada uma política

64 U.S. Department of defense. Proliferation Security Initiative. Disponível em: <http://www.defense.gov/home/features/2014/0814_psi/>. Acesso em: 7 dez. 2014.

65 Trata-se de um instituto internacional independente dedicado à pesquisa de conflitos, armamentos, controle de armamentos e desarmamento, criado em 1966 pelo parlamento sueco, tido como um dos centros mais renomados de estudos nessa área. Cf. ABOUT SIPRI (Stockholm International Peace Research Institute). Disponível em: 〈http://www.sipri.org/about〉. Acesso em: 20 nov. 2014. 
em resposta para pavimentar o caminho de uma ação mais vigorosa contra proliferadores. Como resultado, em maio de 2003, o então presidente George W. Bush anunciou a criação da PSI como uma iniciativa multilateral com foco na cooperação para reforçar a aplicação da lei internacional para a interceptação e o confisco de armas ilegais e tecnologias de mísseis ${ }^{66}$.

Resumidamente, a PSI procura impedir a circulação de armas de destruição em massa com base num intercâmbio de informações, no congelamento de ativos financeiros de traficantes de armas e na interdição de navios e embarcações em alto-mar suspeitos de transportarem armas nucleares ${ }^{67}$.

Seu objetivo é o de criar mecanismos adicionais para reforçar a implementação da Resolução 1540, do Conselho de Segurança da ONU, analisada mais acima, por meio da interdição de embarcações para impedir tráfego ilícito de armas e itens a serem utilizados para fabricação de armas de destruição em massa. Seu fundamento não parte de uma organização formal e não conta com um tratado base, mas apenas com a parceria estabelecida entre nações participantes que aderem à declaração dos princípios de interdição estabelecida unilateralmente pelo Departamento de Estado Americano ${ }^{68}$. Mais do que um meio de não proliferação, seria melhor classificada como uma medida de contra proliferação, ativamente prevenindo movimentação de materiais, tecnologia e armamentos, evitando sua disseminação ${ }^{69}$.

É interessante notar que a maior parte das previsões constantes da declaração de princípios atende aos requisitos do direito internacional, ainda que existam incompatibilidades de difícil reconciliação para a atribuição de legitimidade de jurisdição para a interceptação de embarcações em alto $\operatorname{mar}^{70}$. O processo de desenvolvimento da

66 AHLSTRÖM, Christer. Proliferation Security Initiative: International Law Aspects of the Statement of Interdiction Principles. Disponível em: <http://www.sipri.org/yearbook/2005/pressrl/SIPRIYB2 005PRfinal.pdf>, p. 23. Acesso em: 20 nov. 2014.

67 SAMPAIO, Maria Feliciana Nunes Ortigão de. O Tratado de Proibição Completa dos Testes Nucleares $(C T B T)$ : Perspectivas para sua entrada em vigor e para a atuação diplomática brasileira. Brasília: Alexandre de Gusmão, 2012, p. 43-44.

68 U.S. Department of State. Proliferation Security Initiative: Statement of Interdiction Principles. The White House, , Washington, DC. Sep. 4, 2003. Disponível em: <http://www.state.gov/t/isn/c27726.htm>. Acesso em: 20 nov. 2014.

69 LOUKA, Ellie. Nuclear Weapons, Justice and the Law. Cheltenham: Edward Elgar, 2011, p. 242-243.

70 A China, a Indonésia, o Irã e a Coreia do Norte criticam o fundamento legal da PSI sob o argumento de que viola o direito internacional, em particular o artigo 23 da Convenção do Direito do Mar das Nações Unidas. Cf. SAMPAIO, op. cit., p. 44. 
PSI, dessa forma, indica uma mudança na ênfase internacional, que abandonou a identificação da necessidade de serem efetuadas mudanças normativas, para focar em ações concretas que poderiam ser consideradas legais de acordo com as normas internacionais e domésticas já existentes ${ }^{71}$.

Uma demonstração do êxito da iniciativa pode ser constatada pelo número de estados que aderiram à declaração de princípios, atualmente já superando uma centena de países, inclusive diversos que relutam em aderir aos principais pilares do regime institucional de não proliferação ${ }^{72}$.

Deve-se, por fim, destacar que essa iniciativa paralegal foi dimensionada justamente por um dos países que mais insistentemente violam suas obrigações assumidas internacionalmente em prol do desarmamento nuclear, mas que, ainda assim, reúnem poderio que é considerado essencial, ao menos por ora, para a eficácia de qualquer medida criada internacionalmente na busca da não proliferação nuclear: o mundo necessita da musculatura e liderança americana para a aplicação das leis internacionais ${ }^{73}$.

\subsubsection{Iniciativas para o aprimoramento da segurança de materiais nucleares}

Ao lado da necessidade de se aprimorar o aparato internacional contra a ameaça da proliferação nuclear, outro foco das iniciativas paralegais verifica-se na preocupação pela melhoria das condições de segurança dos materiais nucleares.

Nessa frente, destaca-se o Global Threat Reduction Regime, ou regime pela redução da ameaça global, anunciado pelos Estados Unidos em reunião com oficiais da AIEA em 2004, como meio de reforçar segurança nuclear e reduzir risco de terrorismo nuclear. Para essa finalidade, as autoridades americanas anunciaram o objetivo de repatriamento de combustível nuclear de origem russa, o repatriamento de todos os reatores de pesquisa norte-americanos, o inventário de material nuclear ainda não coberto por esforços de

71 AHLSTRÖM, Christer. Proliferation Security Initiative: International Law Aspects of the Statement of Interdiction Principles. Disponível em: <http://www.sipri.org/yearbook/2005/pressrl /SIPRIYB2005PRfinal.pdf>, p. 23. Acesso em: 20 nov. 2014.

72 U.S. Department of State. Proliferation Security Initiative Participants. Bureau of International Security and Nonproliferation.Washington, DC. June 4, 2014. Disponível em: <http://www.state.gov/t/isn/c27732.htm>. Acesso em: 20 nov. 2014.

73 THAKUR, Ramesh. Unilateralism Is Not the Way. In: War in Our Time - Reflections on Iraq, Terrorism and Weapons of Mass Destruction. Tokyo: United Nations University, 2007, p. 37, tradução do original em inglês. 
redução de ameaças internacionais e a conversão de reatores de pesquisa à base de urânio altamente enriquecido para tecnologia à base de combustível com baixo nível de enriquecimento ${ }^{74}$.

Ao lado desse regime norte-americano, deve-se ainda mencionar a Iniciativa contra a Ameaça Nuclear (Nuclear Threat Initiative - NTI), uma organização sem fins lucrativos, apartidária, com a missão de fortalecimento da segurança global por meio da redução do risco do uso e da prevenção da proliferação de armas nucleares, biológicas e químicas, fundada em 2001 pelo ex-senador americano Sam Nunn e pelo fundador da CNN, Ted Turner $^{75}$.

Como um parceiro independente e confiável, a NTI tem sido capaz de impulsionar em meio à burocracia global novos meios de enfrentamento das ameaças postas pelas armas de destruição em massa ${ }^{76}$.

Periodicamente a NTI publica um índice sobre a segurança de materiais nucleares, denominado NTI Index ${ }^{77}$, considerado um dos principais relatórios de análise sobre as condições de segurança de materiais nucleares ao redor do mundo, não apenas para avaliar o estado atual, mas também para encorajar governos a adotarem ações concretas e aprimorar garantias de segurança dos materiais mais mortais do mundo.

É uma iniciativa louvável à medida que se identifica a enormidade de ameaças representadas pela simples existência de materiais nucleares espalhados pelo mundo sem um mínimo de atenção das autoridades no que concerne à sua proteção contra ataques terroristas ou mesmo roubos e furtos. Não apenas em instalações civis, como verificado no ataque cometido contra a usina nuclear na África do Sul, mas, principalmente, na vasta estrutura que remanesceu do esforço nuclear soviético.

É chocante, neste particular, o relato das antigas 'cidades nucleares' soviéticas, cuja atividade produtiva essencial orbitava em torno da produção de combustível nuclear para armas atômicas, muitas das quais permanecem até hoje com armazéns e depósitos com precárias condições de segurança. A título de ilustração, “em meados da década de 1990, o

74 LOUKA, Ellie. Nuclear Weapons, Justice and the Law. Cheltenham: Edward Elgar, 2011, p. 240-241.

75 NTI (The Nuclear Threat Initiative). About NTI. Disponível em: <http://www.nti.org/about/>. Acesso em: 25 nov. 2014.

76 Idem.

77 NTI Nuclear Materials Security Index. Disponível em: <http://ntiindex.org/>. Acesso em: 25 nov. 2014. 
governo da Noruega financiou um estudo abrangente" para avaliar a quantidade de radiação proveniente da cidade de Ozersk. Conforme os resultados divulgados em 1997, conclui-se que a "contaminação teria lançado no ambiente uma quantidade de radiações mais de duas vezes maior do que o acidente de Chernobyl" 78 .

Além dessa constatação, a NTI divulga uma série de eventos que indicam a necessidade do reforço dos mecanismos de segurança dos materiais nucleares, como a apreensão de terroristas na Moldova que possuíam relativa quantidade de material radioativo, em 2007, e mesmo o voo de bombardeios B-52 sobre o território americano para manutenção de rotina, que inadvertidamente portavam seis mísseis contendo ogivas nucleares e que permaneceram desguarnecidos por alguns dias sem que qualquer alerta tivesse sido dado sobre seu momentâneo desaparecimento ${ }^{79}$.

Como observado neste capítulo, os mecanismos desenvolvidos internacionalmente para conter a proliferação e para lutar pelo desarmamento nuclear compõem um verdadeiro complexo interligado de tratados, convenções, resoluções e iniciativas paralegais e parainstitucionais que se complementam e reforçam as condições de eficácia do regime. Entretanto, afora as zonas livres de armas nucleares, que declaram sua ilegalidade em determinadas áreas do globo, e ao lado do projeto da NWC, a Convenção das Armas Nucleares, não se verifica uma norma que tenha declarado o caráter ilegal desse tipo de armamento.

Resta, então, analisar se, à luz de princípios consagrados no direito internacional, é possível concluir se esse tipo de armamento é considerado ou não proscrito, o que será objeto da análise da parte que vem a seguir neste trabalho.

78 LANGEWIESCHE, William. O bazar atômico - a escalada do poderio nuclear. Tradução de José Viegas. São Paulo: Companhia das Letras, 2007, p. 44.

79 NTI Nuclear Materials Security Index. Video: Threat of Nuclear Terrorism. 7 Jan. 2014. Disponível em: <http://ntiindex.org/news-items/threat-nuclear-terrorism/>. Acesso em: 25 nov. 2014. 


\section{PARTE III}

AS ARMAS NUCLEARES À LUZ DOS PRINCÍPIOS E NORMAS APLICÁVEIS AOS CONFLITOS ARMADOS 


\section{Desenvolvimento das Normas aplicáveis aos conflitos armados - Evolução racional para a pacificação}

\subsection{Aspectos gerais sobre as normas aplicáveis aos conflitos armados}

Conforme observado nos capítulos anteriores deste trabalho, apesar do verdadeiro complexo de normas e organizações estabelecidos em âmbito internacional para tratar da questão nuclear, não há nenhuma norma específica que declare a ilegalidade das armas nucleares.

Assim, na presente parte do trabalho será analisado o arcabouço principiológico consolidado ao longo da evolução do direito aplicável aos conflitos armados, um meio de completar a análise do contexto atual do direito internacional para tratar da questão nuclear. Pela natureza da análise ora proposta, faz-se necessária uma breve recapitulação da evolução do direito da guerra, para então serem avaliados os princípios que foram consagrados internacionalmente concernentes a essa questão.

O denominado jus belli, ou direito da guerra, desdobra-se basicamente em duas ramificações principais, a regulamentação do direito à guerra, ou jus ad bellum, e a consolidação de um conjunto de normas e princípios sobre os métodos de se fazer a guerra, ou jus in bello.

Sobre o primeiro, que não será objeto de maiores considerações neste trabalho, cabe frisar que inicialmente ele se desenvolveu sob o dogma da guerra justa, a qual seria admitida como lícita quando o Estado beligerante pudesse identificar justificativas para sua conduta, defensiva ou ofensiva.

A precariedade de tal concepção residia na própria dificuldade de cada Estado encontrar critérios objetivos e generalizadamente aceitos pelos demais para legitimar suas decisões de ir à guerra, recaindo sempre em discursos autocentrados, particularismos e um exacerbado maniqueísmo subjetivo ${ }^{1}$.

MIALHE, Jorge L. Considerações Sobre a História do direito das relações internacionais. In: MIALHE, Jorge L. (Org.). Direito das relações internacionais - ensaios históricos e jurídicos. Campinas: Millenium, 2007, p. 150-151: "Para Grotius, a guerra não era legítima, a não ser que viesse como resposta a uma ofensa ou ao intento de fazer prevalecer um direito injustamente negado. Todavia, o que era uma ofensa ou um direito negado? Além disso, não existindo uma forma obrigatória para a solução dos 
Desse reconhecimento do fato de que

na guerra, dois beligerantes que se digladiam podem ambos ter causa justa, não foi difícil chegar à doutrina de que a guerra era simplesmente um conflito político, e que a questão da justiça da causa envolvida devia ser banida do direito internacional, porque a sociedade internacional não tinha condições de resolvê-la ${ }^{2}$.

As teorias que partiam do fundamento da guerra justa foram então superadas pela crescente normatização construída durante o século XX, que abandonou o contexto em que os Estados pudessem buscar justificativas, mesmo morais ou religiosas, para deflagrar conflitos, e gradativamente limitou o direito à guerra. Assim, o Pacto da Sociedade das Nações, assinado em Versalhes, em 1919, já trazia em seu preâmbulo o reconhecimento de que, "para o desenvolvimento da cooperação entre as nações e para a garantia da paz e da segurança internacionais, importa aceitar certas obrigações de não recorrer à guerra."3

Quase uma década depois, foi assinado o Tratado de Renúncia à Guerra, Pacto de Paris, também conhecido como Briand-Kellog ${ }^{4}$, cujo artigo $1^{\circ}$ condenava o recurso à guerra para a solução de controvérsias internacionais. É importante notar que, no que pese essa explícita condenação, o contexto da época rapidamente evidenciou a tímida contribuição efetiva dessa norma para regular a conduta dos Estados, haja vista que sua assinatura contou com a participação do presidente da Alemanha, a qual, nos anos que se seguiram, foi a principal responsável pela deflagração de diversos conflitos que acabaram por desestabilizar inteiramente o continente europeu, culminando com a Segunda Guerra Mundial.

Somente no segundo pós-guerra, sob a égide da Carta da Organização das Nações Unidas, de $1945^{5}$, é que houve a consolidação de um sistema internacional com regras mais claras sobre a proscrição da guerra e as circunstâncias excepcionais que autorizavam conflitos armados, limitadas às medidas determinadas pelo Conselho de Segurança de

conflitos, a ofensa ou o direito negado entravam no terreno da subjetividade. Bastava ao Estado 'crer' que estava defendendo uma causa justa para que a guerra fosse legitimada".

BULL, Hedley. A sociedade anárquica. Tradução de Sergio Bath. Brasília: UnB/IPRI, 2002. p. 45.

RANGEL, Vicente Marotta. Direito e relações internacionais. 7. ed. São Paulo: RT, 2002.

Ibidem.

Ibidem. 
acordo com o Capítulo VII da Carta, e o direito de legítima defesa previsto em seu artigo 51.

É significativa a contribuição dessas normas para a consolidação de uma sociedade internacional pautada pelo princípio da não intervenção, em que os Estados reconhecem limitações expressas ao exercício de seus desígnios. Mello ${ }^{6}$ assinala com propriedade essa mudança, apontando os efeitos dessa evolução ao ponto em que a guerra deixa de ser um instrumento disponível para a prática política dos Estados:

Com a evolução do Direito Internacional e o início de uma institucionalização da sociedade internacional a nossa matéria passou a ser eminentemente um direito de paz. A guerra deixou de ser uma sanção, ou um modo violento de solução dos litígios internacionais, para ser um ilícito internacional. [...] Até o século XX o "jus ad bellum" pertenceu ao Estado. O DI regulamentava a guerra entre Estados. Atualmente, com a renúncia à guerra, os Estados perderam, teoricamente, o "jus ad bellum". $\mathrm{O}$ uso da força armada está se tornando um monopólio da ONU e o seu emprego por ela não cria propriamente uma guerra, porque é apenas uma ação de política internacional.

Pode-se notar, nessa breve descrição da evolução do direito da guerra, um desenvolvimento contínuo de mecanismos jurídicos e institucionais estabelecidos e respeitados pelos Estados alinhados a um progresso racional das relações internacionais.

Habermas ${ }^{7}$ descreve esse processo como necessário para superar as limitações do sistema do equilíbrio do poder, tornando-se fundamental o estabelecimento de instituições capazes de lidar com os riscos decorrentes do avanço tecnológico dos armamentos e da ameaça da guerra total:

A "balança de poder" em que o sistema internacional baseou-se por trezentos anos colapsou em algum momento entre a Primeira e a Segunda Guerra Mundial, se não antes. Sem uma corte internacional e um poder sancionador supranacional, o direito internacional não poderia ser invocado e implantado à maneira do direito interno. Entretanto, a moralidade convencional e a ética das relações dinásticas asseguraram

6 MELLO, Celso D. de Albuquerque. Curso de Direito Internacional Público. 15. ed. São Paulo: Renovar, 2004, p. 1501-1504. v. 2.

7 HABERMAS, Jürgen. The European Nation-State. In: ___. The Inclusion of the Other - Studies in Political Theory. Editado por C. Cronin. Massachussets: MIT Press, 1998, p. 126-127, tradução livre do original em inglês. 
um certo nível de regulamentação normativa e meios de se fazer a guerra. No século XX, a guerra total destruiu mesmo esse contexto normativo frágil. $\mathrm{O}$ avanço do estágio das tecnologias dos armamentos, a construção de armas, e a proliferação de armas de destruição em massa tornou abundantemente claros os riscos inerentes a essa anarquia de poderes desregulados por uma mão invisível. [...] Uma ordem mundial mais justa política e economicamente é impensável sem instituições internacionais que sejam capazes de tomar iniciativas, e, acima de tudo, sem uma harmonização entre regimes continentais que emergem atualmente, e sem o tipo de políticas que apenas poderiam ser implantadas sob pressão de uma sociedade civil globalmente mobilizada.

O ideal kantiano de uma evolução racional das relações internacionais que propiciasse a conformação de um direito cosmopolita abandona, é possível afirmar, seu caráter meramente utópico.

Uma prova disso é justamente a instauração, mencionada por Habermas, de normas e instituições internacionais aptas a remodelarem o paradigma sobre o qual estão estabelecidas as relações internacionais. Nesse desenvolvimento encetado pela razão, gradativamente a sociedade internacional tende a se alinhar à compreensão de que o aprimoramento das relações de segurança e confiança recíproca era diretamente ligado à melhoria das condições de seu próprio desenvolvimento, mesmo considerado do ponto de vista individual de cada Estado, como bem resume Vieira De Mello: "seria ingênuo pensar que uma determinada sociedade política poderia constituir-se, sobreviver e desenvolver-se dentro de uma sociedade internacional marcada pela insegurança, competição e

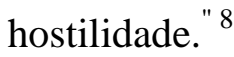

Desta forma, acabaria ocorrendo, como de fato ocorreu sob a égide da ONU, uma convergência para a conformação e o fortalecimento de uma espécie de sociedade das nações como fonte da segurança internacional, que se assemelha ou ao menos que remete ao grande corpo cosmopolítico proposto por Kant em seu Projeto à Paz Perpétua.

A consequência dessa construção é que, mesmo diante de eventos que indiquem retrocessos, é possível identificar significativo avanço rumo à pacificação mundial, sendo

8 MELLO, Sérgio Vieira de. História filosófica e História real: atualidade do pensamento político de Kant. In: MARCOVITCH, Jacques (Org.). Sérgio Vieira de Mello - pensamento e obra. São Paulo: Edusp / Saraiva, 2004, p. 45. 
emblemática a evolução ao ponto que a sociedade internacional passa a considerar a guerra como um ato ilegal, autorizado apenas em limitadas circunstâncias ${ }^{9}$.

Ao lado dessa limitação do direito à guerra, foi notável a consolidação de um vasto conjunto de regras e princípios relativos aos meios de se fazer a guerra, ou seja, quais os limites aos quais os beligerantes estão vinculados durante conflitos armados ${ }^{10}$.

Importante notar que existe, nessa seara, uma divisão do conjunto de regras aplicáveis durante os conflitos armados. Há o conjunto de regras que se destinam à proteção das vítimas da guerra, que se denominaria Direito de Genebra, e há aquele conjunto de normas que impõem o respeito a princípios da humanidade, necessidade e neutralidade durante conflitos armados, classificado como Direito de Haia. Mais recentemente, surgiu uma terceira vertente dessas normas que regulam os meios de se fazer a guerra, a qual se destinaria à proscrição e ao controle de determinados armamentos cujas características os tornariam ilegais per se perante o direito internacional, também conhecido como Direito de Nova Iorque.

Apesar dessa distinção, mais modernamente tem se consolidado a compreensão de que não há sentido em se classificar de modo estanque e apartado esses três ramos. Se, na origem histórica tal classificação fazia algum sentido, especialmente pela gênese de cada um desse conjunto de normas e pela época em que foram assinados os principais tratados internacionais que os consagraram, hoje em dia se compreende uma intensa complementariedade entre eles e uma tendência de integração que torna mais adequada a referência, indistinta a todos os três, sob a expressão "regras do direito internacional aplicáveis em conflitos armados".

No âmbito dessa integração, é interessante destacar a preocupação comum dessas ramificações, desde seu desenvolvimento histórico, com a proteção das vítimas da guerra, tanto civis quanto combatentes, cujo marco original pode ser considerado as Convenções de Genebra, que previam a proteção de soldados feridos e doentes (1864), prisioneiros de guerra (1929), e população civil (1949). Essa tripartição foi compreendida pelas quatro Convenções de Genebra de 1949, um dos principais marcos normativos do assim chamado

9 KELSEN, Hans. Derecho y paz en las relaciones internacionales. 2. ed. Cidade do México: Fondo de Cultura Económica, 1986, p. 59.

10 SILVA SOARES, Guido Fernando da. Curso de Direito Internacional Público. São Paulo: Atlas, 2002, p. 390 . 
Direito de Genebra. Este poderia ser classificado, numa concepção já ultrapassada, como o direito internacional humanitário propriamente dito, stricto sensu. De acordo com essa concepção, o direito humanitário numa visão mais elástica compreenderia ainda o Direito de Haia, que seria destinado a regular os meios pelos quais os Estados poderiam conduzir as hostilidades.

Quando se iniciaram discussões em meados de 1960 sobre a necessidade de se atualizar a lei da guerra, a expressão "direito humanitário" rapidamente prevaleceu. Ao mesmo tempo, havia um apoio generalizado para a necessidade de se incluírem elementos do Direito de Haia no processo de atualização e revisão daquele conjunto de regras sobre a condução das hostilidades. Era um sentimento comum que os métodos modernos e meios de se fazer a guerra suscitavam preocupações humanitárias tais que não poderiam ser ignoradas, num esforço intergovernamental de atualização do direito.

Com esses desdobramentos, o conceito de direito humanitário se desenvolveu rumo a um significado mais amplo, já que o Protocolo Adicional I, de 1977, contém diversas provisões sobre métodos e meios de se fazer a guerra e sobre a proteção de populações civis contra os efeitos das hostilidades.

Torna-se difícil, em vista disso, a manutenção de uma distinção entre o que seria o Direito de Genebra e o que seria o Direito de Haia, sedimentando-se uma concordância em torno da expressão constante do art. 2, subparágrafo b, do referido protocolo: regras do direito internacional aplicáveis em conflitos armados, considerada abrangente o suficiente para se referir às três vertentes acima mencionadas. ${ }^{11}$

A tendência à unificação das três vertentes já era analisada desde o início da década de 1980, valendo notar o quanto afirmava Reuter sobre o processo de alargamento "do direito humanitário propriamente dito, estendendo-o a regras que tendem a proteger os próprios combatentes e a proscrever certas armas." 12

11 ROSAS, Allan; STENBÄCK, Pär. The Frontiers of International Humanitarian Law. Journal of Peace Research, São Paulo, v. 24, n. 3, p. 220-221, 1987. Esse artigo contém interessante descrição da consolidação desse viés integrativo do direito internacional humanitário.

12 REUTER, Paul. Direito Internacional Público. Lisboa: Editorial Presença, 1981, p. 297. Ver ainda Convenção de Viena sobre Direito dos Tratados, artigo 60.,$\S 5^{\circ}$ : "Cessação da vigência de um tratado ou suspensão da sua aplicação como consequência da sua violação. 5 - O disposto nos 1 a 3 não se aplica às disposições relativas à proteção da pessoa humana contidas nos tratados de natureza humanitária, nomeadamente às disposições que pró́bem toda a forma de represálias sobre as pessoas protegidas pelos referidos tratados". 
Esse alargamento possui um efeito muito importante na medida em que, como bem ressaltado pelo autor, "a qualificação de direito humanitário tem consequências práticas, pois as regras que fazem parte desse direito não deveriam ser suspensas por medidas de represálias" (Convenção de Viena sobre o direito dos tratados, art. $\left.60, \S 5^{\circ}\right) .{ }^{13}$

Também no âmbito específico dessa compreensão moderna sobre as regras aplicáveis aos conflitos armados é possível verificar traços que refletem elementos propostos por Kant no seu projeto À Paz Perpétua.

Tome-se a título de ilustração o artigo preliminar 6 de seu projeto, em que há limitações expressas aos meios pelos quais os Estados podem manter suas hostilidades, devendo estar de acordo com regras que resguardem a confiança recíproca na paz futura. ${ }^{14}$

Igualmente importante como limitação aos meios de condução das hostilidades, além da regra para a manutenção das bases necessárias à restauração de relações que permitam a construção de uma efetiva paz futura, é muito atual a vedação contra os meios de guerra que ameacem a própria existência humana, com efeitos avassaladores e generalizados:

com uma guerra de extermínio, em que pode ocorrer simultaneamente a exterminação de ambas as partes e com ela também todo o direito, deixaria existir a paz perpétua somente no grande cemitério do gênero humano . Portanto, uma tal guerra, por conseguinte também o uso dos meios que levam a isso, têm de ser absolutamente não permitidos. ${ }^{15}$

Nesse contexto, a regulamentação dos meios de condução das hostilidades durante os conflitos armados, ao preservar a recuperação de relações regulares e amigáveis entre os beligerantes, evitando a guerra total e a ruptura das relações de coexistência e cooperação internacional, transcende sua função inicial, prestando-se à garantia da continuidade do processo evolutivo rumo a uma ordem cosmopolita e pacificada ${ }^{16}$.

13 REUTER, Paul. Direito Internacional Público. Lisboa: Editorial Presença, 1981, p. 297.

14 KANT, Immanuel. À paz perpétua. Tradução de M. A. Zingano. São Paulo: L\&PM Editores, 1989, p. 30.

15 Ibidem. Ver ainda BOBBIO, Direito e Estado no Pensamento de Emanuel Kant, 3. ed. Tradução de Alfredo Fait.. Brasília: Universidade de Brasília, 1995, p. 162, e CASELLA, Paulo Borba. Pax Perpetua a Review of the Concept from the Perspective of Economic Integration. In: CASELLA, Paulo Borba (Coord.). Dimensão internacional do Direito - Estudos em homenagem a G. E. do Nascimento e Silva. São Paulo: LTr, 2000, p. 78.

16 NARDIN, Terry. Lei, moralidade e as relações entre os Estados. Rio de Janeiro: Forense, 1987, p. 24-25. 
Compreendendo esse caráter evolutivo, vale notar a descrição de Koskenniemi no sentido de que "as limitações objetivas dos métodos de se fazer a guerra advêm do desenvolvimento da civilização em direção a um respeito maior pela vida humana" ${ }^{17}$.

As regras estabelecidas por Kant em 1795, como será visto adiante, também se materializaram e deixaram de fazer parte de um projeto que sofreu críticas por seu caráter utópico e idealista, tendo sido consagradas internacionalmente, ainda que com algumas diferenças, como efetivos limitadores dos meios de condução de hostilidades durante os conflitos armados, a essência do que se também denomina jus in bello.

Esse conjunto de normas, como será observado em mais detalhe no tópico a seguir, parte justamente do princípio da necessária minimização dos males causados pela guerra, valendo-se do binômio da humanidade e necessidade, fatores, como se verá, basilares desse ramo jurídico, e essencialmente complementares para sua efetiva implantação ${ }^{18}$.

Para agir em conformidade com essa regra básica, os Estados estão obrigados a sempre evitar a causação de ofensas desnecessárias ou supérfluas para a consecução de seus objetivos militares. Por isso essas regras do jus in bello compõem um dos principais elementos que permitem avaliar criticamente a ilegalidade ou legalidade do uso ou da mera ameaça $^{19}$ de uso das armas nucleares de acordo com o direito internacional, haja vista seu potencial destacadamente destrutivo.

Essa limitação dos meios de se fazer guerra, se por um lado constituiu um significativo aprimoramento do Direito Internacional, com a ampliação da proteção à pessoa humana, por outro representou uma séria restrição dos meios pelos quais os Estados poderiam implantar suas políticas de segurança nacional e de defesa estratégica, considerando a possível proscrição de determinados armamentos, que, por suas próprias características, passavam a ser considerados ilegais.

Nesse sentido, as regras que se aplicavam às situações de conflito armado determinaram uma nova realidade em que não era mais adequada a concepção clássica da razão de Estado - raison d'état -, a qual se ocupava, essencialmente, das causas da

17 KOSKENNIEMI, Martti. From Apology to Utopia. Cambridge: Cambridge University, 2005, p. 138.

18 ACCIOLY, Hildebrando, NASCIMENTO E SILVA, Geraldo E. do; CASELLA, Paulo Borba. Manual de Direito Internacional Público. 16. ed. São Paulo: Saraiva, 2008, p. 814.

19 WIGHT, Martin. A política do poder. Tradução de Carlos Sérgio Duarte. Brasília: UnB, 1985, p. 39: "Na política do poder a própria ameaça é um ato". 
grandeza e da decadência dos Estados, assim como dos modos de atuação aptos para sua conservação ${ }^{20}$.

Não se pode ignorar que mesmo no período clássico do direito internacional, séculos antes do início da positivação de regras de direito aplicável aos conflitos armados, já havia uma compreensão de que os Estados não possuíam margem irrestrita de medidas necessárias para a defesa de seus interesses, conforme proposto por Vattel:

Desde que uma nação é obrigada a se conservar, ela tem direito a tudo o
que for necessário para esse propósito. Pois a lei natural nos dá direito a
todas aquelas coisas sem as quais nós não poderíamos satisfazer nossa
obrigação. Se assim não fosse, essa lei nos obrigaria ao impossível, ou
então ela seria contraditória consigo mesma, ao nos prescrever uma
obrigação e nos proibir ao mesmo tempo os únicos meios de cumpri-la.
De resto, compreende-se bem, sem dúvida, que esses meios não devem
ser injustos por si mesmos, os quais são proscritos absolutamente pela lei
natural. Como é impossível que essa lei consinta nesses meios, se
porventura em alguma ocasião particular outras leis não surjam para
satisfazer uma obrigação geral, a obrigação deve ser tida, nesse caso
particular, por impossível e consequentemente nula. ${ }^{21}$

Como resultado dessa restrição, as normas do jus in bello encetaram padrões de conduta que afetaram diretamente as avaliações estratégicas e as táticas de guerra, representando, como se afirmou acima, interferência direta na política do poder, "termo coloquial para designar Política Internacional”, a qual, muitas vezes, esvazia o direito internacional por não comungar dos seus métodos ${ }^{22}$.

Se é um dado da realidade que o direito internacional e as relações internacionais possuem uma relação marcada de grande proximidade e muitas vezes de antagonismo, com base nessa breve contextualização já se percebe que a coexistência conflituosa entre elas é especialmente verificada no jus in bello.

Essa realidade reflete-se em inúmeros exemplos de normas cuja motivação de seus apologistas insere-se muito mais numa agenda particular de interesses realistas do que

20 BARBAS HOMEM, Antonio Pedro. História das relações internacionais. Coimbra: Almedina, 2003, p. 135.

21 VATTEL, Emmer de. O Direito das Gentes. Brasília: Universidade de Brasília, 2004, p. 22.

22 WIGHT, Martin. A política do poder. Tradução de C. S. Duarte. Brasília: Editora UnB, 1985, p. 15. 
numa compreensão multilateral e cooperativa da sociedade internacional ${ }^{23}$. Do mesmo modo, não raro se observa uma enorme dificuldade na aceitação e na implantação de normas e no aprimoramento institucional necessário à continuidade da construção e aperfeiçoamento do jus in bello.

Nos tópicos a seguir será resumidamente destacada a evolução histórica do jus in bello, que propiciará a identificação da constante presença do fator político ao longo de seu desenvolvimento, e, na sequência, serão analisados seus princípios essenciais.

A partir dessa análise, será retomada a análise da questão nuclear para evidenciar obstáculos enfrentados (e criados) pela sociedade internacional para aprimorar os mecanismos normativos e institucionais relativos ao desarmamento e à não-proliferação nuclear, e de como aquelas dificuldades acabam contribuindo para um esvaziamento desses mecanismos.

\subsection{Referências históricas e desenvolvimento do jus in bello}

Não são raras as referências históricas de precursores do jus in bello em tempos antigos ou em períodos da humanidade em que ainda não se podia afirmar a existência dos Estados modernos.

Encontram-se referências em distintas civilizações ao longo de épocas variadas que estabeleceram um conjunto central de regras de conduta durante conflitos armados, valendo mencionar as Leis de Manou (Índia), que proibiam o uso de flechas envenenadas, o direito de proteção aos feridos e rendidos, e o respeito das leis das nações conquistadas. Encontra-se também interessante precursor na China, Se-Ma, pensador do século IV A.C., que defendia a proibição, durante as guerras, de destruições inúteis, assim como do ataque a indefesos e feridos.

No Antigo Testamento também há referências sobre um incipiente jus in bello, como a proibição do corte de árvores frutíferas durante os cercos (Deuteronômio, 20, 19-20) e a

23 MELlo, Celso D. de Albuquerque. Curso de Direito Internacional Público. 15. ed. São Paulo: Renovar, 2004. p. 1478. v. 2: "H. Thierry acentua com razão que o controle de armas é uma ação dos EUA e URSS com a finalidade de ser imposta aos demais a fim de reforçarem a sua supremacia. Segundo este autor, uma corrida de armas pode desestabilizá-los". 
regra talmúdica segundo a qual, durante o cerco a uma cidade, devia sempre permanecer uma saída aberta àqueles que desejassem salvar sua vida ${ }^{24}$.

Há iguais referências no mundo islâmico, existindo uma determinação para que, durante conflitos, os prisioneiros de guerra fossem tratados com respeito e dignidade, se respeitassem os velhos, as mulheres e as crianças dos territórios conquistados, e, além disso, a proibição da destruição de palmeiras das casas do inimigo ${ }^{25}$.

Considerando o desenvolvimento mais recente do jus in bello, sua fase embrionária remonta a meados do século XIX, quando surgiram as primeiras declarações e convenções internacionais emanadas em tempos de paz, mas que regulamentavam as condutas a serem verificadas durante conflitos armados.

Em 1856, houve a Declaração de Paris, direcionada à regulamentação de aspectos do direito marítimo em tempos de guerra, que é tida como a primeira iniciativa moderna de regular o direito da guerra. Basicamente, continha regras que proibiam a pirataria, determinava a proteção de embarcações neutras e de bens de nações neutras mesmo se embarcadas em navios inimigos, ressalvada a hipótese de contrabando. Seu escopo não era universalista, restringindo-se formalmente apenas aos seus signatários.

Já aí é possível identificar o aspecto da política do poder moldando os limites de efetividade da criação de normas jurídicas destinadas à regulamentação da guerra, já que a Inglaterra e a França, que à época detinham uma considerável força naval, eram altamente favoráveis a uma liberalização dos mares, apoiando e fomentando a Declaração.

De outro lado, é importante assinalar a reticência dos Estados Unidos, da Espanha e do México em relação à Declaração, uma vez que suas marinhas de guerra eram muito desproporcionais em relação ao extenso litoral a ser defendido por cada um destes países, sendo, portanto, o corso, ou a pirataria, a sua mais importante garantia de reforço beligerante em caso de guerra naval.

24 WEIL, Prosper. O direito internacional no pensamento judaico. Tradução de M. K. Nóbrega. São Paulo: Perspectiva, p. 68 e ss.

25 ALVES PEREIRA, Antonio Celso, O recurso à força pelos Estados e a legítima defesa no direito internacional contemporâneo. In: MENEZES DIREITO, Carlos Alberto; CANÇADO TRINDADE, Antonio Augusto; ALVES PEREIRA, Antonio Celso (Orgs.). Novas perspectivas do Direito internacional contemporâneo - Estudos em homenagem ao Professor Celso D. de Albuquerque Mello. São Paulo: Renovar, 2008, p. 3. 
Nesse marco inicial, portanto, é possível evidenciar a dubiedade da posição das potências mais desenvolvidas naquela época, já que a intenção da Inglaterra e da França não era uma pacificação dos mares ou apenas uma contenção dos males decorrentes da pirataria, mas sim a consolidação de uma situação de preponderância de suas forças navais contra as potências menores.

Poucos anos depois da Declaração de Paris, tem-se o principal marco da criação do direito aplicado aos conflitos armados, a Declaração de São Petersburgo, de 1868, que lançava as bases fundamentais para o aprimoramento e aperfeiçoamento do jus in bello ${ }^{26}$.

Sua origem remonta a Henry Dunant, que, depois de testemunhar o sofrimento cruel dos combatentes durante a Batalha de Solferino (1859), passou a propagar a necessidade da atenuação das calamidades da guerra, lançando as bases da dicotomia necessidade militar vis-à-vis o princípio da humanidade.

O papel de Dunant foi significativo nos anos que sucederam sua experiência em Solferino, tornando-se o fundador da Cruz Vermelha Internacional. Sua mobilização culminou na mencionada Declaração de São Petersburgo, efetivamente o primeiro instrumento internacional que regula os métodos e meios de combate, o qual enunciava o direito consuetudinário então existente ${ }^{27}$.

Já em seu preâmbulo são lançados os princípios que nortearam os esforços da sociedade internacional na regulamentação dos marcos normativos do jus in bello, destacando que o progresso da civilização deveria associar-se à necessidade de aliviar as calamidades da guerra, cujo objeto legítimo seria tão somente o enfraquecimento das forças militares do inimigo.

O salto qualitativo vem imediatamente a seguir, ao se estabelecer que referido objetivo seria excedido pelo emprego de armas que agravassem inutilmente os sofrimentos dos combatentes neutralizados, ou que tornassem inevitável sua morte, consolidando, assim, leis da humanidade aplicáveis aos conflitos armados.

26 ACCIOLY, Hildebrando, NASCIMENTO E SILVA, Geraldo E. do; CASELLA, Paulo Borba. Manual de Direito Internacional Público. 16. ed. São Paulo: Saraiva, 2008, p. 824: "Mais de uma vez, ulteriormente, princípios análogos foram proclamados, tendentes a evitar, na guerra, rigores inúteis".

27 SOARES, Guido Fernando Silva. Curso de Direito Internacional Público. São Paulo: Atlas, 2002, p. 389. 
A relevância dessa Declaração reside ainda na afirmação da necessidade de distinção entre civis e combatentes, linha mestra do desenvolvimento posterior do jus in bello, e, especialmente, na primeira proibição positivada sobre a utilização de armas que agravassem inutilmente o sofrimento dos feridos ou que causassem mortes desnecessárias, ao considerar ilegal o emprego de projéteis com menos de $400 \mathrm{~g}$ contendo uma carga explosiva ou substâncias incendiárias.

A importância desse documento é evidenciada nos desdobramentos do jus in bello, sendo digno de nota que todas as definições do direito humanitário internacional posteriores à Declaração de São Petersburgo destacaram de algum modo a regra essencial da proibição de agressões que causassem sofrimento humano desnecessário durante conflitos armados: "Conhecido igualmente como 'direito de guerra' e 'direito dos conflitos armados', o direito humanitário internacional procura limitar o sofrimento humano que é inevitável consequência da guerra." 28

O passo significativo que se seguiu na construção desse direito de guerra aplicável aos conflitos armados ocorreu nas Conferências de Paz de Haia. A primeira delas, de 1899, teve poucos resultados práticos, muito provavelmente em virtude de sua gênese ter partido de uma agenda pragmática do Czar Nicolau II $^{29}$, não necessariamente objetivando a efetiva construção de normas que visariam à ampliação e consolidação do direito internacional humanitário.

A consequente pequena contribuição da Primeira Conferência da Haia de 1899 para o direito internacional humanitário pode ser atribuída ao já mencionado aspecto do aparelhamento político de iniciativas que seriam destinadas ao aprimoramento do direito internacional nessa temática estritamente vinculada a questões estratégicas dos Estados.

Apesar dessas circunstâncias políticas que esvaziaram a conferência, tratou-se de uma positiva experiência histórica mediante a mobilização da sociedade internacional em torno desse tema, tendo-se chegado ao consenso sobre a proibição de projéteis expansíveis,

28 BYERS, Michael. A lei da guerra - direito internacional e conflito armado. Rio de Janeiro: Record, 2007, p. 143.

29 M. WIGHT, A política do poder. Tradução de Carlos Sérgio Duarte. Brasília: Editora UnB, 1985, p. 203, e MELlo, Celso D. de Albuquerque. Curso de Direito Internacional Público. 15. ed. São Paulo: Renovar, 2004, p. 1479. v. 2. 
o lançamento de bombas por balões ${ }^{30}$, numa preocupação visionária com o iminente desenvolvimento da guerra aérea, e a fundamental proscrição de projéteis que transportassem gases asfixiantes ou nocivos.

Em 1907, foi realizada a Segunda Conferência de Paz da Haia, que logrou profícuos frutos para uma efetiva construção do jus in bello e para o próprio direito internacional. Assim, os esforços da sociedade daquela época, que obtiveram uma importante reafirmação de normas consuetudinárias, lançaram as bases para o posterior desenvolvimento progressivo do direito internacional, conforme bem contextualizado por Cançado Trindade:

Se traçarmos a trajetória dos esforços de codificação e sistematização do direito internacional, desde as Conferências de Paz de Haia de 1899 e 1907 e a Conferência de codificação de Haia de 1930 (além das diversas outras iniciativas de associações científicas internacionais, Universidades e acadêmicas) até a atualidade, talvez sejamos levados à conclusão de que os esforços de hoje, diferentemente dos de outrora, pretendem ir mais além de uma "simples expressão do direito internacional consuetudinário", caracterizando-se sobremodo pelo chamado desenvolvimento progressivo do direito internacional. ${ }^{31}$

A efetiva contribuição da Segunda Conferência de Paz da Haia ao direito aplicável em conflitos armados materializou-se nas diversas convenções e regulamentos anexos que foram assinados, mais especificamente nos Regulamentos Anexos à IV Convenção de Haia de 1907 relativa às leis e usos da guerra terrestre, de onde se destacam diversos artigos que orbitavam em torno dos interesses da humanidade e necessidades da civilização.

Aprofundando o quanto se havia estabelecido na Declaração de São Petersburgo, os regulamentos anexos propiciaram uma revisão e consolidação das leis e costumes da guerra, alinhada com o objetivo de diminuição dos males desnecessários e com a redução de arbitrariedades de comandantes militares ${ }^{32}$.

30 Aí se vê uma quase que imediata confrontação da iniciativa internacional, porque a prática demonstrou rapidamente que essa proibição da guerra aérea não seria respeitada.

31 CANÇADO TRINDADE, Antonio Augusto. Princípios do Direito Internacional. Brasília: Editora UnB, 1981, p. 52.

32 Deve aqui se fazer o registro de que, poucos anos depois da Segunda Conferência de Haia, ocorreu a Primeira Guerra Mundial, ocasião em que todos os envolvidos nela violaram diversas das normas que haviam sido aprovadas, como reconhecido por Theodor Roosevelt em carta citada por Rui Barbosa. Cf. BARBOSA, Rui. A Grande Guerra. Rio de Janeiro: Guanabara, 1932, p. 54. 
Nesse sentido, foi revisitada a Cláusula de Martens, a qual consagrava o princípio da preservação dos objetivos mais elevados que constituíam o cerne do jus in bello ao estabelecer que, para os casos não incluídos explicitamente em alguma norma, os indivíduos (combatentes e civis) estariam protegidos pelos princípios do direito costumeiro, do costume dos povos civilizados, leis da humanidade e consciência pública.

Referida menção aos princípios do direito costumeiro, aos costumes dos povos civilizados e às leis da humanidade é de fundamental relevância por propiciar uma construção propositiva do jus in bello, ou seja, diante de casuísmos não expressamente previstos nas normas consagradas e positivadas, aquele conjunto principiológico deveria ser utilizado pela sociedade internacional para uma interpretação integrativa e evolutiva das normas aplicáveis aos conflitos armados.

Do mesmo modo, como se verá na questão atinente às armas nucleares, tais princípios, universalmente aceitos como emblemáticos das leis da humanidade e da consciência pública, prevaleceriam para a avaliação de armamentos e métodos de se fazer a guerra que fossem descobertos ou aprimorados a partir de então mediante o avanço tecnológico da humanidade.

O caráter consuetudinário do jus in bello, portanto, presta-se ao seu aprimoramento e ao reconhecimento de sua prevalência sobre direitos afirmados por Estados em casos particulares, circunstâncias em que seus interesses unilaterais estariam em xeque. Com efeito, "à falta de um ordenamento jurídico adequado e operante, certos Estados procurariam sempre se reservar a faculdade de decidir sobre a legitimidade de determinadas ações bélicas, por motivos que reputam inseparáveis da segurança de cada um deles" 33 .

Referido núcleo axiológico do jus in bello, nesse sentido, fortalece a paradoxal humanização da guerra e, numa visão mais distante, mas não menos importante, a construção das bases necessárias à própria pacificação mundial.

A seguir serão destacados os princípios essenciais do jus in bello.

33 ABRANCHES, C. A. Dunshee de. Proscrição das armas nucleares. São Paulo: Freitas Bastos, 1964, p. 152. 


\subsection{Princípios essenciais do jus in bello}

Se fosse necessário reduzir o jus in bello a uma fórmula essencial que exprimisse o seu ponto nodal, poder-se-ia afirmar que se trata do ramo do direito internacional que objetiva a limitação dos meios de se fazer guerra em prol de princípios humanitários, da proteção da pessoa humana.

A partir dessa definição é possível retomar o binômio já mencionado da necessidade e da humanidade, cerne que acaba se materializando em diferentes matizes e formas nas diversas normas positivadas e consagradas no costume internacional que constituem o jus in bello.

A humanidade, por exemplo, reflete-se nas inúmeras regras, como a da necessária distinção de civis e combatentes, reduzindo o número potencial de vítimas da guerra; a da precaução, que determina que os beligerantes devam ser conscienciosos no tocante aos efeitos que os armamentos e métodos de guerra possuirão, e à proibição do uso de armas que acarretem danos em larga escala e com grande duração sobre o meio-ambiente.

Em última análise, a humanidade poderia ser considerada como o princípio essencial. Caso colocado de lado, estar-se-ia readmitindo as possibilidades da guerra total, da volta à barbárie.

Já com base na necessidade é que se compreende a regra básica de que os beligerantes devem adotar meios estritamente necessários à consecução de seus objetivos militares, sem causarem danos desnecessários, ou mesmo mortes e ferimentos supérfluos ao inimigo. A necessidade está também ligada à ideia da proporcionalidade, segundo a qual a hostilidade beligerante deve ser proporcional aos objetivos necessários para se coibir eventual ofensa ou agressão.

Há ainda um relevante princípio que, aparentemente secundário, constitui uma verdadeira pedra angular para que o jus in bello se reafirme: a reciprocidade. Quer-se aqui dizer que, caso não fosse imposto, sempre e incondicionalmente, o respeito às regras do direito aplicável às situações de conflito armado, o próprio sistema seria falho ao permitir que determinado Estado descumprisse determinada regra sob a escusa de que não teria a garantia de que seu adversário também a cumpriria. 
A garantia da reciprocidade, vale ressaltar, incide mesmo diante de casos da violação do jus ad bellum, ou seja, o próprio estado agressor encontra-se protegido pelas regras aplicáveis aos conflitos armados já que, se fosse diferente, ele consideraria a possibilidade de adotar meios ilegais de se fazer a guerra por não estar protegido pelo jus in bello.

Dada a relevância operacional da reciprocidade, Reuter reconhece que é a base do respeito do jus in bello na prática, porque não se poderia esperar que um Estado respeitasse regras cujo benefício lhe fosse recusado. ${ }^{34}$

Como uma espécie de domo que se sobrepõe a todos esses princípios, reforçando e confirmando o âmbito de aplicação do jus in bello, há que se destacar seu caráter costumeiro.

O reconhecimento desse caráter consuetudinário é identificado nos próprios marcos normativos que reduziram a um texto legal princípios que já eram observados pelo costume internacional, não sendo outra a razão de ser comum a menção a termos como "princípios humanitários", "valores civilizacionais consagrados universalmente", e a denominada "consciência universal" ${ }^{35}$ (preâmbulo aos regulamentos anexos à IV Convenção de Haia de 1907).

A Cláusula Martens, neste particular, igualmente aponta para o caráter essencialmente costumeiro desse ramo do direito. Não se está, com ela, retirando a relevância dos diversos tratados celebrados que versam sobre essa temática, mas apenas se ressaltando que eventuais lacunas não podem se opor à sua implantação.

Com efeito, ao ser classificado de tal modo, o jus in bello tem sua efetividade protegida de questões técnicas e formalistas, como a ausência de uma norma escrita específica sobre determinada circunstância, haja vista que o próprio preâmbulo da Convenção de Viena Sobre o Direito dos Tratados afirma que as regras do direito internacional costumeiro continuarão a reger as questões que não forem reguladas nas suas disposições.

34 REUTER, Paul. Direito internacional público. Lisboa: Editorial Presença, 1981, p. 298.

35 Identifica-se um traço do ideal kantiano na construção das regras e normas internacionais aplicáveis aos conflitos armados, já que Kant recorre à concepção de uma formação de uma moral universal de acordo com sua análise da evolução da História. 
Esta questão é essencial, por exemplo, quando se está diante de inovações tecnológicas ou políticas que, pela própria natureza novidadeira, não teriam ainda como estar reguladas em algum tratado ou norma específica ${ }^{36}$.

Sobre este ponto é interessante resgatar a discussão sobre a pretensa máxima do direito internacional de que algo que não fosse explicitamente proibido devesse ser considerado, contrario sensu, lícito. Eis o posicionamento adequado da doutrina a esse respeito:

\begin{abstract}
Surgem, porém, a cada dia, novos métodos de combate, novos instrumentos de destruição, que não foram previstos nas leis ou costumes da guerra. Devem, só por isso, ser admitidos? Parece claro que não. Realmente, só devem ser considerados como lícitos aqueles que os princípios gerais do direito internacional não condenam como bárbaros ou pérfidos, ou, antes, os que não forem repudiados pela consciência universal. ${ }^{37}$
\end{abstract}

Essa constatação decorre também da previsão expressa do art. 36, do Protocolo I de 1977 às Convenções de Genebra, que estabeleceu que "no estudo, desenvolvimento, aquisição ou adoção de novos armamentos, as partes estarão obrigadas a observar se a sua utilização seria, em qualquer circunstância, proibida pelo presente protocolo ou por qualquer outra regra do direito internacional aplicável" ${ }^{38}$.

Esse aspecto é muito relevante no que toca às armas nucleares, já que não há normas criadas para declarar sua ilegalidade, circunstância ressaltada de modo determinante na Opinião Consultiva da Corte Internacional de Justiça sobre a legalidade do uso ou da ameaça de uso de armas nucleares, que será objeto de análise do próximo capítulo.

Apenas para antecipar alguma luz sobre a questão, o já citado Abranches, ao lamentar "a luta ideológica e política entre os dois principais grupos de Estados que não permitiu que fosse dado qualquer passo efetivo na direção da proscrição total ou parcial

36 REUTER, Paul, Direito internacional público. Lisboa: Editorial Presença, 1981, p. 288: "Mais do que pôr em dúvida os princípios ou acusar os governos responsáveis, é necessário, sobretudo, sublinhar, duma maneira geral, a extrema diversidade das situações de fato e algumas vezes a novidade dos problemas concretos. Guerrilha, subversão, armamento nuclear colocam problemas novos e difíceis aos quais os princípios devem ser acomodados".

37 ACCIOLY, Hildebrando, NASCIMENTO E SILVA, Geraldo E. do; CASELLA, Paulo Borba. Manual de Direito Internacional Público. 16. ed. São Paulo: Saraiva, 2008, p. 826.

38 OTT, David H. Public International Law in the Modern World. Londres: Pitman, 1987, p. 324. 
das armas nucleares" por ocasião da Conferência de Genebra de 1949, recorre aos princípios do direito aplicável em conflitos armados para reconhecer que "a IV Convenção relativa À Proteção da População Civil em Tempo de Guerra contém vários dispositivos que, reproduzindo os princípios e as proibições consagradas pelas anteriores, são incompatíveis com o emprego da energia nuclear para fins bélicos" 39.

$\mathrm{Na}$ sequência, o mesmo autor conclui que, "do ponto de vista estritamente hermenêutico, o silêncio das Convenções de 1949 sobre as armas nucleares jamais poderia ter a significação de que seriam lícitas, porque foi mantido o princípio da Cláusula Martens"

A fala definitiva sobre o tema parte de testemunha do horror da bomba, sobrevivente de Hiroshima, e que assumiu a prefeitura da cidade durante as duas décadas que se seguiram ao ataque nuclear:

Se gás venenoso, armas biológicas e mesmo balas dun-dun são proibidas pelo direito internacional, o uso da bomba atômica deveria ser considerado um crime contra a humanidade. Essa constatação é irrefutável por quem quer que seja ${ }^{41}$.

Um último princípio central do jus in bello que vale ser mencionado, e que se refere às regras da precaução e da proporcionalidade, é o da neutralidade, segundo o qual devem ser respeitados Estados que não são parte num determinado conflito armado internacional.

Segundo esse princípio, previsto no art. $1^{\circ}$ da Convenção V de Haia de 1907, devem ser protegidos também os respectivos territórios, mares e espaços aéreos dos Estados neutros.

Uma decorrência lógica desse arcabouço valorativo é que há determinados armamentos que, por suas próprias características, independente do uso que se pretenda dar a eles, devem ser considerados ilegais pelas regras do jus in bello.

39 ABRANCHES, C. A. Dunshee de. Proscrição das armas nucleares. São Paulo: Freitas Bastos, 1964, p. 109.

40 Ibidem, p. 109.

41 HAMAI, Shinso. A-Bomb Mayor - Warnings and Hope from Hiroshima. Tradução de Elizabeth W. Baldwin. Hiroshima: Toppan, 2010, tradução livre do original em inglês. 
Armamentos, por exemplo, que necessariamente infrinjam sofrimentos cruéis e desnecessários, cujos efeitos não têm como ser antevistos ou controlados a partir de seu disparo, que afetem de maneira descontrolada o meio-ambiente, não têm como serem justificados de acordo com as regras aplicáveis aos conflitos armados. Vattel, neste particular, já ensinava que, para os atos de defesa, se "podem escolher os meios mais eficazes e apropriados para esse fim, contanto que eles nada tenham de odioso, que não sejam ilícitos por si mesmos e proscritos pela lei da natureza." ${ }^{42}$

Tendo em vista a identificação do núcleo valorativo do jus in bello, é possível compreender com facilidade a razão de ser dos diversos artigos constantes dos tratados e convenções internacionais que versam sobre o tema.

Dos regulamentos de Haia, por exemplo, o art. $1^{\mathrm{o}}$ que discrimina critérios de distinção para os exércitos regulares, milícias e voluntários é relevante porque viabiliza a diferenciação entre civis e combatentes. O art. 22, por sua vez, estampa a limitação imposta aos beligerantes dos meios de ferir inimigo. Indo a fundo nessa linha, o art. 23 contém diversas restrições à conduta na guerra, sejam elas de caráter negativo (proibições) ou positivo (deveres): usar armas envenenadas; matar ou ferir desnecessariamente; proteger rendidos ou indefesos; assegurar possibilidade de rendição; utilizar armas, projéteis e materiais com intenção de causar sofrimento desnecessário; fazer uso indevido de sinais e bandeiras; destruir desnecessariamente propriedade inimiga; declarar abolidos, suspensos ou inadmissíveis os direitos cidadãos de um estado inimigo; e forçar a participação de um indivíduo num ato de hostilidade contra Estado de que seja cidadão.

Seria desnecessário seguir enumerando todos os artigos dessa e das demais convenções e protocolos gerais que a ela sucederam, todos essencialmente respeitando um diálogo muito próximo com as bases axiológicas expostas anteriormente.

Ao lado dessas Convenções de caráter geral, não menos importantes são as diversas convenções particulares que tratam de armas específicas ou de questões pontuais, como o Protocolo do Genebra de 1925, sobre a proibição de guerra química e bacteriológica, cujo preâmbulo afirma ter esta sido "condenada por motivos justos pela opinião geral do mundo civilizado", e a Convenção para a proibição de técnicas de modificação do meio ambiente para fins militares (1976).

42 VATTEL, Emmer de. O Direito das Gentes. Brasília: Editora UnB, 2004, p. 484. 
Complementando o sistema do jus in bello, é necessário ainda que se destaque o Direito de Nova Iorque, atinente ao desarmamento e ao controle de armas proscritas, regulamentado a partir da Convenção sobre a Proibição ou Limitação do Uso de Certas Armas Convencionais que podem ser consideradas como Produzindo Efeitos Traumáticos Excessivos ou Ferindo Indiscriminadamente, e seus protocolos adicionais.

O preâmbulo dessa convenção é muito relevante para o entendimento de como o desarmamento se insere no corpo do jus in bello, mencionando o objetivo de fomentar a détente internacional, o fim da corrida aos armamentos e a instauração da confiança, com o almejado desarmamento generalizado, esforço para o qual o envolvimento da Assembleia Geral das Nações Unidas e a Comissão das Nações Unidas para o Desarmamento podem contribuir de maneira determinante, mediante um possível alargamento do âmbito das proibições e limitações.

Com base no panorama descrito que encampa o jus in bello, será analisada, no capítulo seguinte, a questão particular das armas nucleares, ou seja, se por suas próprias peculiaridades elas devem ou não ser consideradas ilegais e, em caso positivo, as razões pelas quais sua proibição explícita ainda não se verificou, ou mesmo se é necessária uma proibição explícita.

De modo a facilitar essa análise crítica, será utilizada como pano de fundo a Opinião Consultiva emitida pela Corte Internacional de Justiça sobre o tema, uma vez que representa o principal posicionamento judicial sobre o tema, e condensa os principais pontos a serem sopesados para a análise jurídica da questão. 


\title{
2 ANÁLISE CRÍTICA DA OPINIÃO CONSULTIVA DA CORTE INTERNACIONAL DE JUSTIÇA, DE 1996, SOBRE A ILEGALIDADE DO USO OU DA AMEAÇA DO USO DE ARMAS NUCLEARES
}

\subsection{Introdução}

\begin{abstract}
Essas características concedem às armas nucleares um potencial catastrófico. O poder destrutivo das armas nucleares não pode ser contido, seja geográfica seja temporalmente. Elas possuem o potencial de destruir toda a civilização e o ecossistema do planeta inteiro.
\end{abstract}

A sucinta epígrafe a respeito dos traços peculiares que tornam as armas nucleares tão perigosas para a humanidade é uma tradução livre de trecho da Opinião Consultiva emitida pela Corte Internacional de Justiça sobre a legalidade da ameaça ou do uso de armas nucleares, de 8 de julho de $1996{ }^{1}$

É desnecessário aqui repetir a descrição do potencial catastrófico e nefasto inerente às armas nucleares, que determinaram, desde o momento imediatamente seguinte ao seu primeiro uso, em 1945, intensa comoção internacional, conforme observado anteriormente nesta dissertação.

Com o fim da Guerra Fria, entretanto, foi auspicioso o período marcado pelos primeiros anos depois da dissolução da União das Repúblicas Socialistas Soviéticas e a distensão que se seguiu, marcado por inspiradoras iniciativas bilaterais por parte das duas maiores potências nucleares, com a previsão de reduções drásticas de seus arsenais e a limitação de tecnologias que se permitiriam utilizar e desenvolver, conforme McNamara:

O final da Guerra Fria, acompanhado de um crescente entendimento da falta de utilidade das armas nucleares e dos altos riscos associados à sua existência continuada, reforça ambas a oportunidade e a urgência para que as cinco nações nucleares declaradas (China, Estados Unidos, França,

1 INTERNATIONAL COURT OF JUSTICE. Legality of the threat or use of nuclear weapons. Advisory opinion of 8 July 1996. Disponível em: <http://www.icj-cij.org/docket/files/95/7495.pdf>. Acesso em: 3 jul. 2013, tradução livre do original: "These characteristics render the nuclear weapon potentially catastrophic. The destructive power of nuclear weapons cannot be contained in either space or time. They have the potential to destroy all civilization and the entire ecosystem of the planet". 
Inglaterra e Rússia) reexaminem os objetivos de longo prazo de suas forças nucleares ${ }^{2}$.

Havia um otimismo sobre a oportunidade que se apresentava para a sociedade internacional firmar um passo decidido e decisivo rumo a um desarmamento nuclear efetivo:

Quando guerras chegam a um fim, períodos de oportunidade surgem.
Depois da Guerra Fria, as relações dos grandes poderes foi melhorada; o
Conselho de Segurança foi revitalizado; e a ONU foi realocada para o
centro das relações internacionais. Por alguns anos, tanto grandes quanto
pequenos Estados invariavelmente recorreram ao Conselho de Segurança
para pedir autorização e legitimação de operações militares que eles
pretendessem empreender em várias partes do mundo. Em janeiro de
1992, o Conselho, reunido no âmbito dos Chefes de Estado e Governos,
declarou que a proliferação de armas de destruição em massa constituem
uma ameaça à paz e à segurança internacional.

Mas, infelizmente, esses períodos tendem a ser curtos, razão pela qual devem ser aproveitados ao máximo para propiciar saltos qualitativos dificilmente verificados num momento seguinte. A atuação da Corte Internacional de Justiça sobre a questão afeita à legalidade das armas nucleares talvez tenha desperdiçado um desses raros momentos.

No que talvez tenha sido o ápice da mobilização internacional verificada ao fim da Guerra Fria com vistas à obtenção de um mundo livre das armas nucleares, a Assembleia Geral da ONU aprovou, em 6 de janeiro de 1995, a resolução 49/75K ${ }^{4}$, por meio da qual

2 McNAMARA. Robert S. In Retrospect: the Tragedy and Lessons of Vietnam. New York: Times Books, 1995, p. 338, tradução livre do original em inglês.

3 LODGAARD, Sverre. Proliferation: Relevant Factors. In: Curbing the Spread of Nuclear Weapons - an Informal Panel Discussion on the Occasion of the 20th Anniversary of the Vienna International Centre, October 1999. Disponível em: <http://www.iaea.org/newscenter/focus/npt/curbing_spread_ nuclear_weapons.pdf>. Acesso em: 20 jun. 2013, tradução livre do original em inglês.

4 A própria resolução, rapidamente, referiu-se a esse contexto marcado pelo otimismo, ao resumir alguns dos incentivos para sua aprovação: "Mantendo a meta da total eliminação das armas nucleares, desejando a redução, sistemática e progressiva, da ameaça representada pelas armas nucleares, e vendo com bons olhos a redução da intensa competição na acumulação de materiais físseis para usos militares, na produção de armas nucleares e na disposição delas que caracterizaram a Guerra Fria". Cf. UNITED NATIONS. General Assembly. 15 December 1994. 49/75 General and complete disarmament. Disponível em: http://www.un.org/documents/ga/res/49/a49r075.htm. Acesso em: 12 nov. 2014, tradução livre do original em inglês. 
solicitou uma opinião consultiva à Corte Internacional de Justiça ${ }^{5}$, de que se tirou a epígrafe do presente capítulo.

A Assembleia Geral da ONU, como observado anteriormente nesta dissertação, historicamente, sempre se posicionou de modo assertivo contra as armas nucleares, tendo aprovado diversas resoluções reiterando seu caráter ilegal e contrário à Carta da ONU. Emblematicamente, a primeira resolução aprovada por ela referia-se ao tema. Esse seu papel foi resumido no texto da resolução que solicitou a opinião consultiva:

Relembrando suas resoluções 1653 (XVI) de 24 de novembro de 1961 ,
33/71 B de 4 de dezembro de $1978,34 / 83$ G de 11 de dezembro de 1979 ,
35/152 D de 12 de dezembro de $1980,36 / 92$ I de 9 de dezembro de 1981,
45/59 de 4 de dezembro de 1990 e $46 / 37$ D de 6 de dezembro de 1991,
nas quais declarou que o uso de armas nucleares representaria uma
violação da Carta e um crime contra a humanidade.

Em função dessa resolução, à Corte cumpria desempenhar suas funções previstas no art. 65 do seu estatuto, para o que deveria, necessariamente, abordar uma gama enorme de princípios e searas jurídicas, como as regras de não agressão previstas na Carta da ONU, o direito internacional do meio-ambiente e, com especial ênfase, as regras do direito internacional aplicáveis aos conflitos armados.

\subsection{Análise crítica da opinião consultiva}

Não era nenhuma tarefa hercúlea a identificação de que as armas nucleares, pelas suas próprias características, não possuem qualquer possibilidade de serem consideradas lícitas quando analisadas em cotejo com todos os princípios analisados nos tópicos anteriores deste trabalho.

Um ataque nuclear, com os incontroláveis efeitos diretos causados pela intensa liberação de energia e igualmente imprevisíveis consequências indiretas causadas com a contaminação radioativa, romperia, neste sentido, com a necessária distinção entre civis e

5 Segundo A. T. SALIBA, Conselho de Segurança da ONU - sanções e limites jurídicos (Juruá: Curitiba, 2008, p. 166), a relevância dos pareceres da Corte Internacional de Justiça decorre de 'sua autoridade moral', além de conter a 'comprovação do Direito em vigor'.

6 UNITED NATIONS. General Assembly. 15 December 1994. 49/75 General and complete disarmament. Disponível em: http://www.un.org/documents/ga/res/49/a49r075.htm. Acesso em: 12 nov. 2014. 
combatentes; com a obrigação de não serem atacados alvos civis; com o princípio da precaução e da proporcionalidade; com a proibição de uso de armas que afetem o meioambiente de maneira intensa e prolongada ao longo do tempo; a regra da neutralidade, já que não há qualquer possibilidade de se preverem os efeitos prolongados no tempo decorrentes da contaminação radioativa, e, por isso mesmo, contê-los; enfim, por qualquer ângulo que se observe, a ilegalidade das armas nucleares diante do jus in bello é escancarada.

Há raros registros de decisões judiciais sobre a problemática relacionada à legalidade das armas nucleares. Segundo Ott, ao se referir à ilegalidade das armas nucleares, nenhum caso lidou com a questão específica de um ataque nuclear apenas em alvos militares. Em situação oposta, uma corte japonesa, no caso conhecido como Shimoda Case (1963), afirmou que o bombardeio atômico de Hiroshima e Nagasaki representou violação da proibição contra o direito internacional por causar sofrimento desnecessário e indiscriminado entre civis e combatentes. Segundo o autor, seu uso simultâneo contra alvos civis e militares deve ser considerado ilegal por analogia à proibição de armas venenosas e biológicas ${ }^{7}$.

Apesar dessas circunstâncias, não há uma norma internacionalmente estabelecida que afirme esse caráter ilegal. Havia o arcabouço de princípios consagrados pela evolução do direito que regula conflitos armados, valendo destacar o artigo 36, do Protocolo I à Convenção de Genebra de 1949 (1977): "novas armas não podem contrariar qualquer regra de direito internacional".

Essa previsão por si poderia ter sido suficiente para fundamentar a opinião consultiva da CIJ no sentido da ilegalidade das armas nucleares perante o direito internacional, já que, a partir desse artigo, era plenamente factível recorrer-se às regras de aplicação do direito costumeiro, incidente de forma plena no jus in bello, composto pelo conjunto de regras e princípios reconhecidos consuetudinariamente, conforme foi detalhadamente observado no capítulo anterior.

Byers é explícito sobre essa necessária interpretação do direito humanitário internacional ao afirmar que

7 OTT, David H. Public International Law in the Modern World. Londres: Pitman, 1987, p. 325. 
a utilização de armas que provocam ferimentos supérfluos ou sofrimento desnecessário também é proibida pelo direito humanitário internacional, e as armas nucleares, mesmo não sendo proibidas por algum tratado específico, estão sujeitas às limitações do direito humanitário internacional. ${ }^{8}$

Nessa linha, a única conclusão logicamente concatenada com todo o arcabouço normativo e axiológico do jus in bello, igualmente limitador das armas nucleares, é a de que estas são ilegais perante o direito internacional, conclusão que aparentava ser a linha que prevaleceria perante a Corte Internacional de Justiça.

Apesar disso, em sentido contrário, houve Estados que argumentaram, durante os trabalhos preparatórios desenvolvidos pela Corte Internacional de Justiça, que não havia previsão normativa internacional que proibisse explicitamente o uso ou a ameaça do uso de armas nucleares. Diante dessa ausência, argumentaram, não haveria como negar sua licitude.

Apenas essa breve consideração já permite identificar que a interpretação dada pelos Estados à questão acabou reprisando o impasse que dura há décadas, ao menos formalmente desde a aprovação do TNP. Basicamente, os Estados reconhecidamente nucleares, de acordo com os critérios estabelecidos pelo Tratado de Não Proliferação, defenderam a legalidade, em determinadas circunstâncias, daquele tipo de armamento, enquanto a maciça posição dos demais Estados foi, contundentemente, por sua ilegalidade per se.

No que se refere às questões preliminares que foram arguidas pelos Estados, é interessante mencionar o questionamento sobre a possibilidade de a Corte prover a opinião consultiva porque esta envolveria aspectos políticos, não estritamente jurídicos, o que extrapolaria sua esfera de competência. Essa questão preliminar é exemplificativa de como houve, por alguns Estados, postura contrária até mesmo à possibilidade de a Corte emitir sua opinião sobre o tema.

Sobre esse ponto, a Corte ponderou que a questão era efetivamente jurídica, uma vez que fora instada a analisar a compatibilidade do uso ou da ameaça de uso das armas nucleares com base nos princípios e normas do Direito Internacional, identificando quais

8 BYERS, Michael. A lei da guerra - direito internacional e conflito armado. Rio de Janeiro: Record, 2007, p. $153-154$. 
são as normas aplicáveis, interpretando-as e aplicando-as com o fito de oferecer uma resposta fundada no Direito.

Além disso, o fato de a questão envolver aspectos políticos, circunstância muito comum em outros temas que surgem no direito internacional, não foi considerada suficiente para afastar o caráter jurídico do problema. Ainda sobre esse ponto, fez-se menção a trecho da opinião consultiva proferida sobre a Interpretação do Acordo de 25 de março de 1951 entre a OMS e o Egito (1980):

\begin{abstract}
Em situações em que considerações políticas são proeminentes, torna-se particularmente necessário que uma organização internacional obtenha uma Opinião Consultiva da Corte sobre os princípios jurídicos aplicáveis ao tema objeto do debate 9 .
\end{abstract}

Esse entendimento assume relevo para o tema das armas nucleares, profundamente marcado pela agenda política da comunidade internacional e de cada Estado individualmente considerado, tornando-se muito importante a identificação dos princípios e normas aos quais os Estados estão vinculados para que se compreendam quais são as balizas existentes contra discursos unilaterais ou exacerbadamente calcados na defesa irrestrita do exercício irrestrito de sua soberania.

A partir daí, a Opinião Consultiva emitida pela Corte aborda detalhadamente praticamente todas as questões centrais atinentes à avaliação da legalidade ou da ilegalidade das armas nucleares, tais como o direito à vida, as normas de proteção internacional do meio-ambiente, a regulamentação do uso da força pela Carta da ONU, os princípios do direito costumeiro aplicáveis aos conflitos armados, o direito internacional humanitário e o princípio da neutralidade.

Nos termos da análise desenvolvida pelos juízes da Corte, cada um desses itens, isoladamente, permitiria a afirmação de que as armas nucleares, pelas suas próprias características, deveriam ser consideradas ilegais.

Apesar disso, em sua conclusão afirmou que não existiam elementos suficientes que permitissem uma conclusão certeira de que o uso de armas nucleares representaria uma

9 INTERNATIONAL COURT OF JUSTICE. Déclaration de M. Bedjaoui. Ménace ou emploi d'armes nucléaires. Disponível em: <http://www.icj-cij.org/docket/files/95/7499.pdf>. Acesso em: 3 jul. 2013. 
violação, em qualquer circunstância, dos princípios e normas jurídicas aplicáveis aos conflitos armados, inicialmente por não ter identificado algum tratado que positivasse uma norma internacional pelo banimento ou pela declaração da ilegalidade das armas nucleares ${ }^{10}$. Esse entendimento alinha-se a um comportamento histórico da Corte, que sempre recusou assumir um papel legiferante, sendo que suas decisões e pareceres fundamentam-se "nos limites do direito existente" ${ }^{11}$.

Para fundamentar esse posicionamento, a Corte destacou que não se poderia perder de vista o direito de cada Estado à sobrevivência, e, consequentemente, seu direito ao exercício da autodefesa quando sua sobrevivência se encontrasse ameaçada, conforme previsto no art. 51 da Carta de São Francisco.

$\mathrm{Na}$ realidade, entre os diversos pontos debatidos na formulação da opinião consultiva, no que respeita à conclusão sobre a legalidade ou ilegalidade das armas nucleares, houve um empate, sendo, então, proferido voto de minerva pelo presidente da Corte à época, M. Bedjaoui, que, pela relevância, é resumido a seguir ${ }^{12}$ :

Em relação às armas nucleares, a humanidade tem vivido sob um tipo de sentença suspense. Por meio século essas terríveis armas têm constituído parte da condição humana, havendo sido inseridas em todos os cálculos, cenários, planejamentos. Desde Hiroshima, na manhã de 6 de agosto de 1945, o medo gradualmente tornou-se a primeira natureza do homem. [...] A humanidade está sujeitando a si própria a uma perversa e incessante chantagem nuclear. A questão é como se livrar dela. A Corte possui um dever de desempenhar seu papel nessa questão, no resgate da humanidade; ela o fez de maneira cuidadosa e humilde, respeitando os limites impostos tanto pelo seu estatuto quanto pelo direito internacional aplicável. [...] Ela procurou evitar todas as tentações de criar uma nova lei e certamente não extrapolou seu papel ao urgir aos Estados que criem normas o mais rapidamente possível para completar o trabalho já desenvolvido até hoje. [...] Como consta da opinião consultiva, em nenhum momento a Corte perdeu de vista o fato de que as armas nucleares constituem um potencial de destruição de toda a humanidade. Em nenhum momento ela falhou em considerar esse fator eminentemente crucial para a sobrevivência da humanidade. O dilema moral que confronta as consciências individuais foi refletido na opinião da Corte. Mas, obviamente, ela não poderia ultrapassar o que as leis estabelecem, não poderia afirmar o que elas não o fazem. [...] Não possuo dúvidas de

10 GINGER, Ann Fagan. Nuclear Weapons Are Illegal - The Historic Opinion of the World Court and How It Will Be Enforced. New York: The Apex, 1998, p. 50-52.

11 KOSKENNIEMI, Martti. From Apology to Utopia. Cambridge: Cambridge University, 2005, p. 35.

12 INTERNATIONAL COURT OF JUSTICE. Déclaration de M. Bedjaoui. Ménace ou emploi d'armes nucléaires. Disponível em: <http://www.icj-cij.org/docket/files/95/7499.pdf>. Acesso em: 3 jul. 2013. 
que a maioria dos princípios do direito humanitário e, em qualquer caso, os dois princípios - proibição do uso de armamentos que causem efeitos indiscriminados e que causem sofrimento desnecessário - constituem parte do jus cogens. A Corte suscitou esse tema na presente opinião; inobstante, ela afirmou que não havia a necessidade de prover qualquer conclusão sobre esse ponto uma vez que a questão da aplicação do direito humanitário contra as armas nucleares não se situava no escopo do que fora solicitado pela Assembleia Geral da ONU. Ainda assim, a Corte expressamente afirmou que essas regras fundamentais constituem "princípios intransponíveis do direito internacional consuetudinário". O direito de um estado à sobrevivência é também um direito fundamental, similar em vários aspectos a um "direito natural". Entretanto, a autodefesa - se exercida diante de extremas circunstâncias em que sua própria sobrevivência estivesse ameaçada - não poderia acarretar uma situação em que esse Estado seria desobrigado de cumprir as normas intransponíveis do direito internacional humanitário. Em determinadas circunstâncias, portanto, poderia surgir um confronto insolúvel, uma colisão de princípios fundamentais, nenhum dos quais podendo ser submetido ao outro. $\mathrm{O}$ fato que remanesce é que o uso de armas nucleares por um Estado em circunstâncias em que sua sobrevivência encontra-se altamente arriscada, de seu turno, ameaçaria a sobrevivência de toda a humanidade, precisamente por causa da indissociável relação entre o terror e a previsível escalada do uso dessas armas. Seria, nesse sentido, imprudente situar a sobrevivência de um Estado sobre quaisquer outras considerações, em particular sobre a sobrevivência da própria humanidade. [...] Decorre do quanto exposto que a ameaça ou o uso de armas nucleares em geral contraria as regras de direito internacional aplicáveis em conflitos armados, e, em particular, os princípios e regras do direito humanitário. Contudo, de acordo com o estágio atual do direito internacional, a Corte não pode concluir definitivamente se a ameaça ou o uso de armas nucleares seria legal ou ilegal diante de uma extrema circunstância de autodefesa, em que a própria sobrevivência de um Estado esteja em jogo.

Pela complexidade inerente ao tema, refletida no empate que houve entre os juízes da Corte, todos eles apresentaram votos em separado. Apenas para ilustrar rapidamente alguns dos principais fundamentos daqueles que votaram pela legalidade das armas nucleares, cabe uma breve análise do voto do vice-presidente da Corte, juiz Stephen M. Schwebel ${ }^{13}$, que criticou a decisão da Corte de aceitar a incumbência posta pela Assembleia Geral por possuir natureza claramente política. Ele ainda aprofundou a crítica ao afirmar que, depois de aceitar a incumbência, a Corte não poderia haver chegado a uma interpretação inconclusiva, que ele reputou non liquet.

13 INTERNATIONAL COURT OF JUSTICE. Dissenting opinion of Vice-President Schwebel. Threat or use of nuclear weapons (Ménace ou emploi d'armes nucléaires). Disponível em: <http://www.icjcij.org/docket/files/95/7515.pdf>. Acesso em: 3 jul. 2013. 
No que se refere ao mérito da questão, o juiz Schwebel descreveu que a prática internacional relacionada às armas nucleares apontava sua fabricação e distribuição estratégica pelo mundo, e que, tanto por tratados quanto pela experiência da ONU, ainda se estava longe de uma proibição de tais armas. Ainda em relação a essa prática, ele destacou que ela não se verificava em estados párias, mas nas principais potências que formam o sustentáculo central de poder do principal órgão decisório das Nações Unidas.

Com base nessas considerações, o juiz afirmou que até o completo desarmamento, a existência das armas nucleares, que em si representa uma ameaça, e seu potencial uso, não constituiriam uma violação das normas de direito internacional. Para sustentar essa conclusão, o juiz Schwebel citou o importante papel das armas nucleares na prevenção da escalada perigosa de conflitos, exemplificando esse raciocínio com uma experiência de 1990, às vésperas da primeira invasão ocidental contra o Iraque. Referia-se a uma reunião do Secretário de Estado James A. Baker, ocorrida em 9 de janeiro de 1990, em Genebra, com o Ministro das Relações Exteriores iraquiano, Tariq Aziz, na qual o primeiro teria afirmado: "se o conflito envolver o uso de armas químicas ou biológicas contra as forças americanas, o povo americano exigirá vingança. Nós possuímos os meios de executá-la. No que tange à minha fala, não se trata de uma ameaça, mas de uma promessa”.

O problema no exemplo citado pelo juiz decorre da percepção de que, na hipótese por ele aventada, por pior que fosse um ataque com armas químicas contra as forças americanas - sabia-se que o Iraque possuía arsenais de armas químicas -, tal ataque não chegaria sequer perto de se assimilar a uma gravíssima circunstância em que a sobrevivência dos Estados Unidos estivesse ameaçada. Essa constatação assume ainda maior gravidade quando se verifica que, na sequência, o juiz Schwebel acrescenta que não apenas Estados párias, mas criminosos e fanáticos que ameacem ou efetuem atos terroristas também podem ser submetidos à dissuasão ou resposta nuclear ${ }^{14}$.

Verifica-se, aí, um perigoso viés interpretativo do que estaria abarcado sob o conceito de autodefesa, não sendo possível considerar mera coincidência a fundamentação do posicionamento da Corte justamente no alegado direito à autodefesa. Byers afirma, nesse sentido, que "historicamente, a legítima defesa costumava ser uma justificação

14 GINGER, Ann Fagan. Nuclear Weapons Are Illegal - The Historic Opinion of the World Court and How It Will Be Enforced. New York: The Apex, 1998, p. 89 e ss. 
política de atos que, de um ponto de vista jurídico, não passavam de atos comuns de guerra". ${ }^{15}$ Mais à frente, o autor expõe que a Corte, um dos principais órgãos criados sob os auspícios da ONU, ao hipertrofiar o direito à autodefesa, acaba permitindo a corrosão da própria autoridade das Nações Unidas:

Os Estados Unidos, ao pressionarem por esta e outras ampliações do direito de legítima defesa, não só aumentam sua própria liberdade de agir como diminuem o papel e a autoridade das Nações Unidas. O pragmatismo pode ser atraente, mas tem um preço. ${ }^{16}$

Martin Wight, também abordando o direito previsto no art. 51 da Carta, explicita que se trata de uma das principais fontes que corroem a construção de uma realidade multilateral efetivamente operante. Segundo o autor, trata-se de uma válvula de escape aos limites que o sistema de veto representa sobre o processo decisório do Conselho de Segurança:

$\mathrm{O}$ artigo 51, que reconhece o direito de autodefesa individual ou coletiva na hipótese de o Conselho de Segurança não conseguir cumprir sua função. $\mathrm{O}$ direito à autodefesa individual é o princípio básico da anarquia internacional; o direito à autodefesa coletiva é o princípio do equilíbrio do poder; e esses dois princípios sobreviveram com pujança sobre as ficções da Carta. $\mathrm{O}$ artigo 51 virou o veto do avesso ao reconhecer que uma maioria de potências não pode ser impedida de cooperar com o fito de adotar fora de uma organização internacional uma política que o regime de unanimidade a impede de adotar dentro da organização. ${ }^{17}$

Martti Koskenniemi, em reforço, ao destacar que a linguagem normativa internacional é intencionalmente marcada por expressões indeterminadas ou de difícil interpretação, um meio de os Estados reservarem ampla discricionariedade na sua aplicação, ilustra seu argumento referindo-se ao termo "autodefesa", ao lado de "agressão", "guerra", "intervenção" ou "combatente"

15 BYERS, Michael. A lei da guerra - direito internacional e conflito armado. Rio de Janeiro: Record, 2007 , p. 71-72.

16 Ibidem, p. 79.

17 WIGHT, Martin. A política do poder. Tradução de C. S. Duarte. Brasília: Editora Universidade de Brasília, 1985, p.177.

18 KOSKENNIEMI, Martti. From Apology to Utopia. Cambridge: Cambridge University, 2005, p. 38-39. É interessante uma discussão similar destacando a complexidade da interpretação da 'autodefesa', que seria 
Assim, uma crítica à opinião consultiva, dada a extrema relevância dessa exceção autorizadora do uso de armas nucleares, seria a ausência de uma assertiva mais enfática a respeito de como se deveria interpretar o conceito da "autodefesa" para excepcionar as normas de direito internacional humanitário, especialmente em relação às limitações para que se pudesse constatar a possibilidade de sua alegação.

A polêmica relação entre o conceito de autodefesa e sua aplicação no que toca às armas nucleares é também causada pelo fato já mencionado nesta dissertação de que a Carta da ONU foi elaborada antes de que a humanidade tivesse conhecimento daquelas armas:

$\mathrm{O}$ art. 51, como toda a Carta, se estruturou antes de que fosse conhecida a energia nuclear. É evidente que a circunstância da possibilidade de se empregar energia atômica na técnica militar tem que alterar o princípio de ataque armado, porque o primeiro ataque atômico, do ponto de vista militar, pode ser decisivo. A única defesa possível é a preventiva. ${ }^{19}$

Além da questão da possibilidade de se defender de um ataque nuclear, ainda no que tange à relação entre autodefesa e as armas atômicas, parece incontroverso que a resposta de um Estado contra um ataque não pode ser desproporcional à agressão sofrida ${ }^{20}$. Por isso Abranches considera que a única hipótese em que o uso de armas nucleares seria aceito pelo direito internacional seria no caso de se tratar de uma resposta a um ataque da mesma natureza ${ }^{21}$.

ainda mais problemática caso inseridos outros conceitos vagos, como o da 'necessidade extrema' para legitimar condutas teoricamente ilegais. Cf. JOHNSTONE, Ian. The Use of Force. In: BOULDEN, James; THAKUR, Ramesh Chandra; WEISS, Thomas George (Coords.). The United Nations and Nuclear Orders. Tokyo: United Nations University, 2009, p. 137-138.

19 ARÉCHAGA, Eduardo Jiménez de. Derecho Constitucional de las Naciones Unidas. Madrid: Escuela de Funcionarios Internacionales, p. 403, apud ABRANCHES, C. A. Dunshee de. Proscrição das armas nucleares. São Paulo: Freitas Bastos, 1964, p. 106.

20 ALVES PEREIRA, Antônio Celso. O recurso à força pelos Estados e a legítima defesa no direito internacional contemporâneo. In: MENEZES DIREITO, Carlos Alberto; CANÇADO TRINDADE, Antônio Augusto; ALVES PEREIRA, Antônio Celso. Novas perspectivas do Direito internacional contemporâneo: Estudos em homenagem ao Professor Celso D. de Albuquerque Mello. São Paulo: Renovar, 2008, p. 15-16: “A legítima defesa é, desta forma, uma faculdade subsidiária, provisória e controlada. [...] se as ações levadas a cabo em nome da legítima defesa forem excessivas, o Estado que se defende pode passar de agredido a agressor".

21 ABRANCHES, C. A. Dunshee de. Proscrição das armas nucleares. São Paulo: Freitas Bastos, 1964, p. 165-167. 
Ao lado desse argumento central relacionado à autodefesa como fundamento para a decisão da Corte, deve ser também analisada a alegação de que a prática internacional impediria a afirmação da ilegalidade das armas nucleares. Nesse sentido, contra a proscrição dessas armas pesaria o amplo apoio internacional dado à política da dissuasão nuclear, fundada na ameaça velada do uso de armas nucleares decorrente de sua mera posse.

Uma vez que, segundo se alega, os Estados aceitaram essa prática ao longo das últimas décadas, tratar-se-ia de direito costumeiro que albergaria a legalidade das armas nucleares. Ainda a respeito da prática internacional, foram destacadas as reservas manifestadas por todas as potências nucleares em relação ao banimento ou à declaração de proscrição das armas nucleares, como quando ressalvaram seu direito a recorrer a elas mesmo na oportunidade de adesão a tratados que tinham por meta a declaração de zonas livres de armas nucleares (capítulo 4, segunda parte).

Essa menção às reservas manifestadas pelas potências nucleares por ocasião da assinatura de tratados é interessante porque, a um só tempo, expressa a relevância das relações de poder que atribuem às potências nucleares status diferenciado e quase as exime de tratamento equiparável ao recebido pelos demais Estados, e ignora que a comunidade internacional vem se posicionando de maneira extremamente crítica contra essa relutância dos poderes centrais de se desarmarem de acordo com o art. VI, do TNP, ou de apoiarem iniciativas concretas que propiciem, um dia, o desarmamento geral.

Ilustrando essa questão, merece destaque a manifestação escrita apresentada pelo governo mexicano durante os trabalhos preparatórios da Corte $^{22}$ :

Cientes desses perigos, os Estados vêm destacando a questão do desarmamento nuclear ao longo de muitas décadas. No presente, portanto, a total eliminação de armas nucleares é um dos principais compromissos da comunidade internacional. [...]

Apesar de o TNP ser geralmente identificado como um instrumento vital para a segurança internacional, ele conduziu ao estabelecimento de um regime discriminatório em favor das cinco potências nucleares. [...]

22 INTERNATIONAL COURT OF JUSTICE. Note Verbale dated 19 June 1995 from the Embassy of Mexico, together with Written Statement of the Government of Mexico. Disponível em: <http://www.icjcij.org/docket/files/95/8694.pdf>. Acesso em: 3 jul. 2013. 
Para legitimar esse regime discriminatório e assegurar equilíbrio entre os direitos e as obrigações das partes, os Estados assumiram a obrigação de negociarem em boa-fé medidas efetivas para se obter o desarmamento nuclear. [...] De acordo com essa obrigação, a posse de armas nucleares e, consequentemente, o regime discriminatório do TNP apenas pode ser interpretado como temporário, até que seja obtido o objetivo final da completa eliminação dessas armas. [...]

Nesse sentido, a decisão adotada na Conferência de Revisão e Extensão do TNP, pela qual foi decidida sua extensão indefinidamente, jamais poderia ser interpretada como legitimadora da posse das armas nucleares em uma perspectiva indefinida. A declaração do México naquela ocasião, adotada por consenso, reiterou que a extensão indefinida do TNP não significava a perpetuação da dicotomia entre estados nucleares e não nucleares.

Assim, em vez de se manifestar pela ilegalidade das armas nucleares, a Corte ignorou o que de fato vem constituindo o comportamento dos Estados sobre as armas nucleares, e se alinhou ao cenário já armado, preferindo - de forma prudente ou negligente, a depender dos critérios interpretativos - expor todo o arcabouço valorativo e normativo que permitiria inferir a ilegalidade de tais armas, sem, contudo, efetivamente formular essa conclusão.

O comportamento aparentemente dúbio ${ }^{23}$ da Corte pode ser explicado pela impossibilidade de declarar a legalidade daquelas armas, e da provável crise de legitimidade que sofreria caso afirmasse a sua ilegalidade, uma vez que seriam muito remotas as chances de que as potências nucleares respeitassem essa decisão e se desfizessem de seus arsenais atômicos.

Com efeito, como as armas nucleares modelaram o ambiente internacional durante décadas por meio da política da dissuasão, caso a ameaça de uso fosse declarada ilegal, toda a prática internacional desde a Segunda Guerra seria considerada ilegítima. Por outro lado, se fosse declarada sua legalidade, o tabu nuclear seria destruído e o potencial uso de armas atômicas seria envolvido por uma perigosa permissividade. Por isso, a opinião consultiva da Corte apenas refletiu mas não resolveu a polêmica existente sobre a questão,

23 Foi tão detalhada a descrição da Corte sobre as regras que determinam a necessária ilegalidade das armas nucleares, que houve diversas manifestações doutrinárias que praticamente ignoraram a guinada dada ao final da opinião consultiva, abrindo perigosa margem interpretativa para relativizar o caráter ilegal daqueles armamentos. Cf. GINGER, Ann Fagan. Nuclear Weapons Are Illegal - The Historic Opinion of the World Court and How It Will Be Enforced. New York: The Apex, 1998, p. 1-13. 
prevendo que as nações nucleares não respeitariam a eventual declaração da ilegalidade daquelas $\operatorname{armas}^{24}$.

Não se pode ignorar que uma decisão que fosse atacada pelo descumprimento justamente pelos Estados que mais deveriam respeitá-la, as nações nuclearmente armadas, traria efeitos muito negativos na luta pelo desarmamento nuclear, legitimando ainda mais a insatisfação dos demais Estados e a decisão de alguns deles de adotarem planos de militarização nuclear. Nesse sentido, é interessante a ponderação de Kelsen de que

não se deve empreender nenhum intento de reforma que esteja destinado a fracassar, mesmo que sejam boas as intenções dos intelectuais que os propaguem, porque o fracasso envenenaria ainda mais a atmosfera internacional e comprometeria a ideia da paz, a única esperança que temos de um futuro melhor para o mundo ${ }^{25}$.

A única proposição efetivamente formulada pela Corte foi no sentido de instar a comunidade internacional à adoção efetiva de mecanismos capazes de fomentar um completo desarmamento nuclear, status que resolveria as controvérsias sobre o tema pelo próprio desaparecimento de sua causa.

\subsection{Avaliação dos efeitos da decisão}

Há que se lamentar o posicionamento adotado pelos juízes da Corte. Por mais que se reconheça a dura tarefa que lhes havia sido imposta, a conclusão da Opinião Consultiva possui um viés negativo de relativizar todo um conjunto de normas e princípios que vem sendo construído e sedimentado há séculos no direito internacional como um meio de se evitarem as barbáries da guerra, humanizando-a, na medida do possível.

Nesse sentido, foi perdida uma oportunidade ímpar para que fosse dado um passo concreto no sentido do robustecimento dos meios pelos quais o desarmamento nuclear poderia ter sido aproximado da realidade e deixado de ser considerado um ideal distante e quase utópico.

24 LOUKA, Ellie. Nuclear Weapons, Justice and the Law. Cheltenham: Edward Elgar, 2011, p. 309-317.

25 KELSEN, Hans. Derecho y paz en las relaciones internacionales. Tradução de Florencio Acosta. 2. ed. Cidade do México: Fondo de Cultura Económica, 1986, p. 203, tradução livre do original em espanhol. 
Convergindo para esse objetivo, pode ser citada a declaração escrita apresentada pelo ministro das relações exteriores da Bósnia Herzegovina ${ }^{26}$ durante os procedimentos preliminares à elaboração do parecer da Corte, tendo naquela sido exortada a possibilidade deste servir como um guia imperativo para os esforços internacionais por um mundo mais pacífico.

A solução pragmática adotada pela Corte ignorou, de modo ainda mais grave, toda uma evolução das fontes e dos princípios aplicáveis ao direito internacional com base na concepção do pós-positivismo, cujo sentido é o de atribuir aos princípios uma função também normativa. Essa concepção consiste, portanto, num meio de fortalecer o respeito ao já consagrado núcleo do jus cogens no âmbito do direito internacional. Os princípios, nessa medida, abandonam "papel que inicialmente seria apenas o de suplementar tratados e costumes, e passam a consagrar valores e metas a serem alcançados". ${ }^{27}$

Além disso, essa vagueza diante de temas de difícil trato no direito internacional acaba fortalecendo discursos unilaterais que se alimentam da fraqueza institucional, então mais evidente, contribuindo para uma desconstrução do aparato institucional-normativo que comumente é criticado justamente por sua fragilidade, como expõe Lafer:

Normas comuns, no entanto, não levam necessariamente a interpretações
compartilhadas em comum. Os Estados diferem na sua análise do alcance
e da aplicação de normas e buscam, quando lhes cabe proceder
unilateralmente ao processo de qualificação jurídica dos fatos, conduzi-lo
em função dos seus interesses específicos. ${ }^{28}$

Exatamente nesse sentido, não tardou para que fossem sentidos os efeitos negativos relacionados à timidez da atuação da Corte Internacional de Justiça sobre o tema.

${ }^{26}$ INTERNATIONAL COURT OF JUSTICE. Letter dated 16 June -1995 from the Minister for Foreign Affairs of Bosnia and Herzegovina. Disponível em: <http://www.icj-cij.org/docket/files/95/8708.pdf>. Acesso em: 15 jul. 2013.

27 SALIBA, Aziz Tuffi. Conselho de Segurança da ONU: sanções e limites jurídicos. Curitiba: Juruá, 2008, p. 101. Ver ainda F. REZEK, Direito internacional público - curso elementar. 13. ed. São Paulo: Saraiva, 2011, p. 173.

28 LAFER, Celso. Comércio, Desarmamento e Direitos Humanos - reflexões sobre uma experiência diplomática. $2^{a}$ ed. São Paulo: Paz e Terra, 2006, p. 42-43. 
Em fevereiro de 2003, por exemplo, o secretário de Defesa britânico declarou que a Grã-Bretanha se reservava o direito de usar armas nucleares contra o Iraque em caso de “extrema legítima defesa”, fundando essa ameaça velada no parecer consultivo de 1996.

Naquele ano, o único Estado cuja sobrevivência estava em xeque era o próprio Iraque, país que, conforme se descobriu na sequência, fora invadido injustificadamente sob a equivocada acusação de possuir um programa secreto de produção de arsenais nucleares e de outras armas de destruição em massa ${ }^{29}$.

Nessa declaração, a Corte fora citada para embasar um argumento de questionável legalidade adotado pela Grã-Bretanha, que se valeu de critérios interpretativos distorcidos sobre o conceito de autodefesa ${ }^{30}$, que não seriam possíveis caso houvesse um posicionamento mais assertivo sobre a ilegalidade das armas nucleares.

Por mais que um ataque contra suas forças no exterior ou contra seus aliados, mesmo se valendo de armas de destruição em massa, seja um ato grave no plano estratégicomilitar, não se estaria diante de uma ameaça à existência do país. Um revés militar que não ameace a continuidade da existência do país, por exemplo, não autoriza de maneira irrestrita e incondicional a ameaça de uma resposta nuclear.

Neste particular, é oportuna a lição de Amaral Júnior ${ }^{31}$, com apoio em Charles Beitz:

O direito de preservação nacional ganha sentido na hipótese de proteger a vida dos cidadãos contra ameaças externas, mas a sua aceitação diminui quando se trata de defender a integridade territorial e quando essa defesa não afeta a vida e o bem-estar da população.

Essa constatação por si só bastaria para lamentar a conclusão da Corte, neste particular também porque fortaleceu um discurso contrário à boa-fé na interpretação, por parte das potências nucleares, de suas obrigações assumidas no âmbito do art. VI do Tratado de Não Proliferação de Armas Nucleares, cuja redação não permite dupla margem

29 BYERS, Michael. A lei da guerra - direito internacional e conflito armado. Rio de Janeiro: Record, 2007, p. 155.

30 A Federação russa, nos trabalhos preparatórios perante a Corte, também se manifestou de maneira vaga sobre a autodefesa. Cf. INTERNATIONAL COURT OF JUSTICE. Letter dated 19 June 1995 from the Ambassador of the Russian Federation, together with Written Comments of the Government of the Russian Federation. Disponível em: <http://www.icj-cij.org/docket/files/95/8796.pdf>. Acesso em: 3 jul. 2013.

${ }^{31}$ AMARAL JUNIOR, Alberto do. O direito de assistência humanitária. São Paulo: Renovar, 2003, p. 19. 
de interpretação sobre a natureza das obrigações assumidas por todos os signatários com vistas a um desarmamento nucelar:

Cada parte do Tratado reconhece que deve negociar em boa-fé medidas efetivas relacionadas à cessação da corrida armamentista nuclear em curto prazo e ao desarmamento nuclear, e um tratado sobre o geral e completo desamamento sob estrito e efetivo controle internacional.

Como observado, a decisão da Corte acabou contrariando manifestações anteriores dela própria, em que havia reconhecido, na análise do caso envolvendo os testes nucleares, entre Austrália e França,

que 'um dos princípios básicos a reger a criação e cumprimento das obrigações legais, qualquer que seja sua fonte, é o princípio da boa-fé' e que 'a confiança recíproca era uma condição inerente à cooperação internacional, particularmente numa era em que a cooperação internacional em diversas áreas se torna cada vez mais essencial'. Consequentemente, na concepção da Corte, Estados têm a obrigação de respeitar as expectativas que criam através de suas manifestações ${ }^{32^{\circ}}$.

Os Estados Unidos alinharam-se à interpretação britânica que alargava os limites aplicáveis ao exercício do direito à autodefesa, para considerar a possibilidade do uso de armas nucleares mesmo diante de ameaças contra suas forças existentes no exterior ou contra seus aliados. Mais ainda, a decisão da Corte foi considerada inócua para afetar em qualquer aspecto o status quo, verdadeiro non liquet:

Pouco depois de ser emitida a opinião consultiva, um assessor legal do Departamento de Estado formulou um ensaio sobre a Opinião Consultiva com a proposição de que nada nela sugeriria uma mudança na postura e na política dos EUA ou da OTAN ${ }^{33}$.

Conforme se viu anos depois, essa posição norte-americana foi confirmada com a divulgação da Estratégia Nacional de Combate a Armas de Destruição em Massa,

32 SALIBA, Aziz Tuffi. Conselho de Segurança da ONU - sanções e limites jurídicos. Curitiba: Juruá, 2008, p. 121.

33 DAMROSCH, Lori Fisler. Codification and Legal Issues. In: BOULDEN, James; THAKUR, Ramesh Chandra; WEISS, Thomas George (Coords.). The United Nations and Nuclear Orders. Tokyo: United Nations University, 2009, p. 174. 
publicada em dezembro de 2002, como se indicou no capítulo 2, da primeira parte desta dissertação.

Considerada a posição central dos Estados Unidos no cenário mundial, essa posição calcada numa leitura elástica do direito à autodefesa contrária ao direito internacional representava uma clara ameaça aos demais Estados. Essa ameaça, por sua vez, possuía um perigoso efeito corrosivo das bases que deveriam manter, ou fomentar, condições de confiança recíproca necessárias à via do desarmamento.

Caso a Corte tivesse privilegiado um posicionamento mais assertivo sobre a ilegalidade das armas nucleares, e, mais importante, sobre quais seriam as condições especialíssimas em que ameaças concretas à continuidade da existência de um Estado poderiam ensejar o uso ou ameaça de uso de tais armamentos numa resposta militar já desesperada, não é impossível que houvesse uma coibição ou ao menos um significativo constrangimento contra manifestações como a norte-americana.

Uma postura mais corajosa dos juízes da Corte teria possivelmente ensejado um efeito moralizante para a questão do desarmamento nuclear, importante marco evolutivo na construção de sua efetiva concretização. Esse efeito construtivo seria sentido gradualmente, ele mesmo assumindo a função de propiciar mudanças e encetar padrões de comportamento.

Observar-se-ia, novamente, a função pacificadora correlata à questão do desarmamento. Para a busca de um estado perene de paz, os Estados deveriam reconhecer o conceito de um direito efetivo e submeter-se a ele, mesmo com justificativas para permanecerem atribuindo à força e ao poder a prevalência sobre aquele. Distanciando-se do moralista político, que subordina os princípios ao fim, Kant, como já visto no capítulo 3, da primeira parte deste trabalho, cita sua máxima: “age de tal forma que tu possas querer que tua máxima deva tornar-se uma lei universal" ${ }^{\text {34 }}$.

34 KANT, Immanuel. À paz perpétua. Tradução de Marco Antônio Zingano. São Paulo: L\&PM Editores, 1989, p. 68. 
Entretanto, não foi devidamente aproveitada aquela oportunidade de reafirmação do direito internacional, que, em vez de se ver fortalecido, acabou vendo estampada sua fragilidade e suas limitações, sua sujeição às regras da política de $\operatorname{poder}^{35}$.

Nesse sentido, a conclusão da Corte permitiu um caminho reverso ao descrito nos parágrafos anteriores. No lugar de uma construção de bases concretas rumo ao desarmamento nuclear, fez com que outros Estados, não detentores de arsenais nucleares e que até então se inseriam no âmbito dos aparatos da não proliferação nuclear, testemunhando um aprofundamento das instabilidades dos pilares do sistema que acreditavam coerente e coeso, passaram a representar potenciais ameaças ao regime da não-proliferação, com perigosos efeitos para o equilíbrio das relações internacionais.

Basta notar, a título ilustrativo, que, durante os procedimentos preliminares à elaboração do parecer consultivo da Corte, tanto a República Democrática da Coreia quanto o Governo da República Islâmica do Irã manifestaram-se em prol da necessidade de se declararem proscritos os armamentos nucleares.

A manifestação norte-coreana ${ }^{36}$, por exemplo, era contundente ao afirmar que a ameaça ou o uso de armas nucleares em qualquer hipótese representava uma violação da Carta da ONU e das leis internacionais, e, portanto, aquelas armas não poderiam ser admitidas em absoluto, chegando inclusive a destacar que era deplorável o debate quando a completa eliminação das armas nucleares vinha sendo seriamente discutida na arena internacional.

O governo iraniano ${ }^{37}$, de seu turno, apontava que a inexistência de uma norma que proibisse explicitamente as armas nucleares jamais poderia ser considerada como escusa para seu uso, recorrendo aos princípios e às regras do direito internacional humanitário para sustentar sua posição, devido à natureza destrutiva daquelas armas.

35 MARCOVITCH, J. Um brasileiro na História do Mundo. In: MARCOVITCH, J. (Org.). Sérgio Vieira de Mello - pensamento e obra. São Paulo: Edusp/Saraiva, 2004, p. 15.

${ }^{36}$ INTERNATIONAL COURT OF JUSTICE. Letter dated 18 May 1995 from the Permanent Representative of the Democratic People's Republic of Korea to the United Nations. Disponível em: http://www.icj-cij.org/docket/files/95/8668.pdf. Acesso em: 1 jun. 2013.

37 INTERNATIONAL COURT OF JUSTICE. Note Verbale dated 19 June 1995 from the Embassy of the 1slamic Republic of Iran, together with Written Statement of the Government of the Islamic Republic of Iran. Disponível em: http://www.icj-cij.org/docket/files/95/8678.pdf Acesso em: 1 jun. 2013. 
Ao final de sua manifestação, é interessante o argumento iraniano de que não seria lógico concluir que as armas nucleares seriam permitidas quando a comunidade internacional já havia considerado proscritas armas de destruição em massa cujos efeitos eram muito menos danosos para a vida humana.

Menos de duas décadas depois de terem sido apresentadas essas duas declarações, esses dois países hoje representam as mais sérias ameaças contra o regime de nãoproliferação nuclear, sendo mencionados em qualquer documento ${ }^{38}$ e relatório que se produza a esse respeito.

A consequência negativa da opinião emitida pela Corte de legitimar o discurso pela manutenção da posse de armas atômicas, e proliferação nuclear, é bem resumida por Damrosch:

Se mais de um Estado no mundo de hoje - Coreia do Norte depois de ser rotulada como parte do eixo do mal, Israel em face das ameaças iranianas de ser varrido do mapa - pudessem alegar com plausibilidade que a posse e ameaça crível de uso de armas nucleares são as únicas salvaguardas numa "extrema circunstância de autodefesa, em que sua própria sobrevivência estivesse em risco", a opinião da Corte atribuiria inegavelmente legitimidade a essa alegação ${ }^{39}$.

Essa consequência é, paradoxalmente, conforme observado, fruto da conduta das próprias potências nucleares, as quais, desde 1968, data em que foi assinado o TNP, jamais deram um passo concreto no sentido de implantar um geral e completo desarmamento nuclear.

A mesma postura ambígua das principais potências nucleares que explica de maneira muito plausível a guinada na postura de países como o Irã e a Coreia do Norte no que tange à proliferação nuclear segue sendo objeto de críticas pelo seu efeito potencialmente desagregador e desestabilizador das relações internacionais.

38 LODGAARD, Sverre. Proliferation: Relevant Factors. In: Curbing the Spread of Nuclear Weapons: an Informal Panel Discussion on the Occasion of the $20^{\text {th }}$ Anniversary of the Vienna International Centre. Outubro 1999. Disponível em: <http://www.iaea.org/newscenter/focus/npt/curbing_spread_ nuclear_weapons.pdf>. Acesso em: 30 nov. 2014.

39 DAMROSCH, Lori Fisler. Codification and Legal Issues. In: BOULDEN, James; THAKUR, Ramesh Chandra; WEISS, Thomas George (Coords.). The United Nations and Nuclear Orders. Tokyo: United Nations University, 2009, p. 175. 
Neste particular, ainda que não haja mais sentido em se valer da bipolaridade EUAURSS para explicar as relações internacionais atualmente, os dois países permanecem como os principais detentores de vastos arsenais atômicos mesmo em comparação com os demais Estados que detêm potencial nuclear para fins bélicos, e perpetuam suas políticas de segurança baseadas nessas armas ${ }^{40}$.

Sua conduta, portanto, como será observado no próximo capítulo, acaba sendo um dos entraves essenciais para o bom funcionamento do aparato normativo-institucional engendrado para conter a proliferação nuclear e desenvolver as bases necessárias para seu gradual banimento.

40 LAFER, Celso. Comércio, desarmamento e direitos humanos - reflexões sobre uma experiência diplomática. 2. ed. São Paulo: Paz e Terra, 2006, p. 129-130. 


\section{PARTE IV}

\section{DESARMAMENTO DIFICULTADO PELA POLÍTICA INTERNACIONAL}




\section{O COMPORTAMENTO DA PRINCIPAL POTÊNCIA COMO PRINCIPAL OBSTÁCULO}

Ao longo do presente trabalho, uma característica que se repetiu na avaliação crítica dos inúmeros instrumentos e das diversas iniciativas, sejam essas institucionalmente organizadas, ou para-institucionais, foi um notável comportamento dos estados nuclearmente armados dificultando a concretização dos objetivos de todo esse aparato.

Ainda que não se concorde com tal conduta, ela é compreensível, uma vez que a consecução das metas propostas pelas iniciativas que lutam pelo desarmamento nuclear global alteraria completamente as bases em que está assentado o tabuleiro atual das relações internacionais ${ }^{1}$. Nesse sentido, Bull afirma que

o contexto da ordem internacional é bastante desfavorável aos projetos que pretendem realizar a justiça cosmopolita ou mundial, porque o controle das questões permanece sob o controle dos estados, e eles não parecem interessados em abrir mão desse controle ${ }^{2}$.

Durante o período da Guerra Fria, esse controle acabou sendo consagrado na consolidação da política da dissuasão como o principal elemento das políticas estratégicas de segurança e defesa internacional. Tanto a ameaça de destruição mútua, quanto o incontestável poderio das duas nações que lideravam os dois blocos antagônicos impediram qualquer avanço concreto na questão do desarmamento nuclear. Com efeito, o principal tratado celebrado sobre o tema, o TNP, foi erigido sob um viés discriminatório que refletia as principais características desse cenário.

Não se irá, neste momento, reprisar a análise daquele período, conhecido também como primeira era nuclear, para o que se remete ao capítulo 2 da primeira parte, e aos capítulos 1 e 2 da segunda parte deste trabalho.

1 Novamente se faz necessária a ressalva assinalada na primeira parte desta dissertação, quanto à existência de outros aspectos que permitem tranquilamente afirmar que, mesmo sem a discrepância bélica atual, ainda assim se manteria elevado poder concentrado nas mãos das principais nações do mundo. Cf. GADDIS, John Lewis. The Unexpected John Foster Dulles: Nuclear Weapons, Communism and the Russians. In: IMMERMAN, Richard H. John Foster Dulles and the Diplomacy of the Cold War. New Jersey: Princeton University, 1990, p. 55.

2 BULL, Hedley. A sociedade anárquica. Tradução de Sergio Bath. Brasília: UnB/IPRI, 2002, p. 102-103. 
O foco agora se volta à análise desse comportamento no contexto do pós-Guerra Fria, que, como já descrito, inicialmente foi visto como uma etapa esperançosa em relação aos impactos positivos que se esperavam do fim do antagonismo bipolar, com a distensão mundial de rivalidades que poderia atenuar o risco da ameaça nuclear ${ }^{3}$.

Contudo, os desdobramentos frustraram as expectativas auspiciosas, tendo o mundo se deparado com cenário fragmentado de múltiplas incertezas, com uma sensação de desestabilização generalizada que logo forneceu meios para se renovar o discurso das potências para a perpetuação de seu poderio nuclear. Segundo Hobsbawm,

o fim da Guerra Fria retirou de repente os esteios que sustentavam a estrutura internacional e, em medida ainda não avaliada, as estruturas dos sistemas políticos internos mundiais. E o que restou foi um mundo em desordem e colapso parcial, porque nada havia para substituí-los ${ }^{4}$.

Em meio a essa nova realidade incerta, uma consequência imediata foi a consolidação dos Estados Unidos como principal poder hegemônico ${ }^{5}$. Apesar da aparente posição vantajosa atribuída por essa hegemonia, os riscos decorrentes do abuso desse papel no foro internacional eram motivo de alerta logo no início daquele período:

Os anos imediatamente a seguir serão particularmente difíceis para os americanos, seja pela ação unilateral, seja por argumentos não rivalizados, ou ambos, por constituírem o erro da intransigência absoluta. Em qualquer nível em perspectiva, qualquer vantagem marginal obtida

3 BUNDY, McGeorge; CROWE JR., William J.; DRELL, Sidney D. Reducing Nuclear Danger - The Road Away from the Brink. Nova York: Council on Foreign Relations Press, 1993, p. 45.

4 HOBSBAWM, Eric. Era dos extremos. Tradução de Marcos Santarrita. 2. ed. São Paulo: Companhia das Letras, 1995, p. 251.

5 A liderança global propiciada pelo poder incomparável norte-americano já antecedia o fim da Guerra Fria, como dá conta a Lei de Não Proliferação Nuclear, sancionada pelo Presidente Carter em 10 de março de 1978. Ao influenciar o licenciamento de exportações de materiais nucleares, essa lei foi imposta, na prática, aos países membros da Comunidade Europeia de Energia Atômica (Euratom), contrariando a regra de supremacia de lei internacional sobre a lei interna. A referida lei, fruto de uma potência consciente de sua força negociadora, atingia outros países com a finalidade de obter maior controle da proliferação nuclear. Cf. MAGALHÃES JÚNIOR, Japy Montenegro; MARQUES, Fernando Mário Rodrigues. A proliferação nuclear. Revista de Administração Pública, Rio de Janeiro, v. 12, n. 4, p. 173-197, out./dez.1978. Disponível em: <www.spell.org.br/documentos/download/ 15540>. Acesso em: 15 nov. 2014, p. 189-192. 
dessa maneira não teria valor real, comparada com os danos políticos, que seriam muito sérios ${ }^{6}$.

Esse tipo de alerta já era conhecido há décadas, como ilustra a citação do memorando de reunião do Conselho Nacional de Segurança dos Estados Unidos de 24 de junho de 1954:

Genebra proveu a confirmação de que 'a maré está correndo contra nós no canal dessa política intransigente. Se devemos continuar essa linha, nós deveremos perder diversos de nossos aliados, e apenas isso já nos compele a rever nossa política. [...] devemos reconhecer o fato de que não podemos pretender conduzir o mundo livre, e, de acordo com isso, revisar nossa política básica de segurança ${ }^{7}$.

No período iniciado com a derrocada da URSS, as ameaças contra a segurança internacional não eram mais identificáveis principalmente pelo risco de ataque de nações rivais, mas sim por movimentos insurgentes, terrorismo e meios assimétricos e difusos de combate $^{8}$. A combinação desse cenário com o destaque dos Estados Unidos como maior poder mundial engendrou o acirramento da intransigência de suas políticas de segurança, devido à "sensação de insegurança por se sentir o principal alvo de terroristas", causando "sérias divergências com outros países e minando a capacidade de cooperação e interação, notadamente em questões de desarmamento e controle de armas" 9.

O discurso pela segurança levou os Estados Unidos a agirem como "se estivessem em uma realidade unipolar, isolando-o cada vez mais no mundo”. A pretensa condução dos assuntos internacionais "rogando a si o ato de estarem falando em nome da 'comunidade

6 BUNDY, McGeorge; CROWE JR., William J.; DRELL, Sidney D. Reducing Nuclear Danger - The Road Away from the Brink. New York: Council on Foreign Relations Press, 1993, p. 37-384, tradução livre do original em inglês.

7 GADDIS, John Lewis. The Unexpected John Foster Dulles: Nuclear Weapons, Communism and the Russians. In: IMMERMAN, Richard H. John Foster Dulles and the Diplomacy of the cold War. New Jersey: Princeton University, 1990, p. 52, tradução livre do original em inglês.

8 CIMBALA, Stephen J. Nuclear Weapons and Cooperative Security in the 21st Century - the New Disorder. New York: Routledge, 2010, p. 49-50.

9 RAMINA, Larissa; CUNHA FILHO, Valter Fernandes da. Segurança internacional. Curitiba: Juruá, 2013, p. 47. 
internacional""10 era confrontada pelas dúvidas quanto à sua legitimidade como líder global, corroída pela incerteza quanto "a quem pertencia a segurança em questão, e à custa de quem ela é obtida" ${ }^{11}$.

Nesse contexto que ampliava a sensação de insegurança pelo isolamento do país, os Estados Unidos viam-se envolvidos num complexo cenário internacional, em que a bandeira do desarmamento nuclear fora muito fortalecida, sendo intensamente defendida nesses primeiros anos que se seguiram ao término da Guerra Fria, como foi observado no capítulo anterior. Ainda assim, não ocorria uma adesão convicta dos Estados Unidos em relação ao desarmamento nuclear, ou a medidas que pudessem colaborar para fomentá-lo.

Esse impasse era problemático pela ausência de uma ideologia que justificasse a manutenção de sua política de segurança amarrada em torno de seus arsenais atômicos, com o desaparecimento do principal argumento que havia se prestado a essa política até 1991. Assim, é possível identificar um paradoxal alívio dos líderes do país depois dos terríveis atentados de 11 de setembro de 2001, que

forneceram ao governo norte-americano o elemento que faltava para a consolidação de uma doutrina capaz de preencher esse vácuo. [...] A nova estratégia de segurança nacional não deixa dúvidas de que a principal vítima dos atentados terroristas de 11 de setembro foi o direito ${ }^{12}$.

A questão posta pelo terrorismo internacional, especialmente de como a retórica política desenvolvida em torno dela é exagerada para propiciar essa legitimação da política nuclear, constitui um tema essencial para analisar o comportamento das principais potências como um dos principais obstáculos para o objetivo do desarmamento nuclear.

Ao lado dessa questão do terrorismo, outro aspecto complicador dessa segunda era nuclear é o crescente número de países que vêm ameaçando o regime de não proliferação. Faz-se necessária uma avaliação das respostas dadas contra essas ameaças, em especial

10 HUNTINGTON, Samuel P. A superpotência solitária. In: DUPAS, Gilberto; LAFER, Celso; SILVA, Carlos Eduardo Lins da (Orgs.). A nova configuração mundial do poder. São Paulo: Paz e Terra, 2008, p. 142.

11 WIGHT, M. A política do poder. Tradução de C. S. Duarte. Brasília: Editora Universidade de Brasília, 1985 , p. 32.

12 RAMINA, Larissa; CUNHA FILHO, Valter Fernandes da. Segurança internacional. Curitiba: Juruá, 2013, p. 49-50. 
pelas nações nuclearmente armadas, que, além de serem de legitimidade questionável, foram de duvidosa eficácia, e, reversamente, atribuíram argumentos e incentivos para a insistência dos proliferadores em suas iniciativas nucleares:

\begin{abstract}
Contudo, noutros casos como o Iraque, e suas alegadas ADM jamais encontradas pela coalizão após a ocupação do território daquele país desde 2003, ou mesmo da Coreia do Norte e do Irã, acusados pelos EUA de desenvolverem programas nucleares em desrespeito às obrigações assumidas com a AIEA, identifica-se um movimento político liderado pelos EUA de interesse em ações militares preventivas, a despeito de prévia autorização do Conselho de Segurança da ONU, para não se permitir a ruptura destes países com as obrigações internacionais assumidas, para se preservar um paradigma de segurança interna que os EUA cuidaram de projetar internacionalmente por suas ações unilaterais, no mínimo de legalidade questionável. ${ }^{13}$
\end{abstract}

Esses dois temas serão analisados a seguir.

\title{
4.1 (In)Capacidade da dissuasão nuclear de confrontar o terrorismo internacional
}

O terrorismo internacional é um tema de enorme complexidade ${ }^{14}$, porque coloca em xeque uma série de normas e princípios do direito e das relações internacionais, muitas vezes pondo Estados que são vítimas de atentados numa situação de total impotência em relação a uma retaliação.

Diferentemente de uma agressão conduzida por um ente estatal, é difícil realizar uma resposta armada contra um grupo insurgente porque, muitas vezes, ele sequer é identificado com o país cujo território é utilizado como base de suas estruturas e operações ilegais, impedindo que um ataque seja cometido em resposta contra esse determinado país.

Existem, é claro, iniciativas como monitoramento via satélite de determinadas áreas do globo, que permitem ataques seletivos de questionável legitimidade jurídica por meio de bombardeios e investidas por veículos não tripulados contra as instalações terroristas. Porém, essas operações levam muito tempo para serem implementadas, às vezes não mais se conectando contra o atentado sofrido mas representando uma política externa de

13 MORE, Rodrigo Fernandes. Direito Internacional do Desarmamento: O Estado, a ONU e a paz. São Paulo: Editora Lex, 2007, p. 130-131.

14 Para interessante descrição da evolução histórica do terrorismo ver SEITENFUS, Ricardo; VENTURA, Deisy. Direito Internacional Público. 4. ed. Porto Alegre: Livraria do advogado, 2006, p. 224-226. 
segurança, e também elas não se inserem no que se considera um ataque autorizado no exercício da autodefesa.

Além desse aspecto polêmico, não se pode ignorar o terrorismo internacional como "arma política, estimuladora da instabilidade internacional"15, já que "consiste no reino do medo, que emprega a luta desigual, a violência e a morte como seus instrumentos de ação. [...] a hegemonia contemporânea do terror instaura um mundo de sombras sem paralelo histórico" $"$.

Essa descrição aborda uma consequência muito preocupante do terrorismo, além de seu viés desestabilizador, qual seja, a instauração de uma realidade pautada pelo "mundo de sombras". Para fazer frente à ameaça terrorista, os Estados veem-se despidos de meios jurídicos legítimos, ao passo que são pressionados a atender ao anseio generalizado de respostas enérgicas seja para preveni-la, seja para retaliá-la.

No âmbito doméstico, essa consequência possui efeitos nefastos contra garantias fundamentais, uma vez que

a comunidade, desacreditada de um Direito Penal comum que não previne e não consegue responsabilizar os agentes do crime altamente organizado e transnacional, exige ao Estado segurança (cognitiva e real) a todo o custo, mesmo que crie um Direito penal específico ou excepcional para esse tipo de criminalidade e o delinquente deixe de ser pessoa e passe a ser um inimigo, uma não pessoa ${ }^{17}$.

Dessa forma, o

fenômeno terrorista promove uma redução da aplicabilidade imediata dos direitos, liberdades e garantias processuais face à destruição maciça e indiscriminada e à indeterminabilidade e ilegibilidade das vítimas inocentes, que facilita uma nova posição jurídica do poder político

15 CASELLA, Paulo Borba. Direito Internacional, terrorismo e aviação civil. São Paulo: Quartier Latin, 2006, p. 29.

16 Ibidem, p. 98.

17 VALENTE, Manuel Monteiro Guedes. Direito Penal do Inimigo e o Terrorismo - O 'Progresso ao Retrocesso'. Coimbra: Almedina, 2010, p. 17. 
legislativo que intermedeia a limitação de direitos, liberdades e garantias processuais até à aniquilação de quaisquer direitos ${ }^{18}$.

Talvez a mais emblemática das respostas recentes contra o terrorismo internacional que ilustre esse comportamento contrário aos direitos e garantias fundamentais seja o Patriot Act, lei americana aprovada na sequência dos ataques de 11 de setembro de 2001, que, com fundamento na guerra contra o terrorismo,

admite a tortura, a privação ilimitada da liberdade sem decisão judicial ou culpa formada, a supressão de todas e quaisquer garantias processuais penais, a criação de tribunais especiais militares para questões de crime, o cancelamento do habeas corpus e a violação de todos os direitos, liberdades e garantias ${ }^{19}$.

Vê-se, assim, o enorme risco representado por esse tipo de resposta radical, com o que "a reação ao terrorismo pode irmanar-se a este e fazer-se seu igual, como terrorismo dito "de estado",20. Dessa forma, ao submeter o mundo à constante ameaça do terror imprevisível, acaba-se instaurando um regime do medo, perigosamente permissivo e utilitarista, que reduz as ações a uma "relação de meios e fins, em que tudo não passa de uma forma de violência [...]. Um mundo em que as pessoas perdem a capacidade de julgar, pois tudo tem uma explicação" ${ }^{21}$. Internacionalmente, não sem exagero, é possível se falar numa "esquizofrenia belicista" causada pelo terrorismo ${ }^{22}$.

Esse viés assumiu proporções muito maiores depois dos ataques cometidos contra os Estados Unidos em 11 de setembro de 2001, atentados inéditos quando se pensa em sua complexidade na elaboração, sucesso na execução, e devastadores resultados, paralisando a principal nação do mundo, que não conseguia sequer compreender o que estava ocorrendo. O caráter simbólico daqueles atentados verifica-se pela implosão de um dos monumentos

18 VALENTE, Manuel Monteiro Guedes. Direito Penal do Inimigo e o Terrorismo - O 'Progresso ao Retrocesso'. Coimbra: Almedina, 2010, p. 26.

19 Ibidem, p. 99.

20 CASELLA, Paulo Borba. Direito Internacional, terrorismo e aviação civil. São Paulo: Quartier Latin, 2006, p. 24. Segundo Ricardo Seitenfus e Deisy Ventura (Direito Internacional Público. 4. ed. Porto Alegre: Livraria do advogado, 2006, p. 228), terrorismo de estado seria o "terrorismo oficial, quando representantes do poder público agem de forma clandestina, com ou sem conivência de seus superiores hierárquicos, utilizando-se dos meios que o Estado dispõe para cometer atos de terror". Os autores citam como um triste exemplo a chamada Operação Condor.

${ }^{21}$ Ibidem, p. 167.

22 VALENTE, op. cit., p. 100. 
que melhor representavam o poder financeiro do país, as Torres Gêmeas, e a sede de seu poder militar, o Pentágono. A reação que causou, na mesma medida, foi sem precedentes, como bem resume Hobsbawm ${ }^{23}$ :

Mas, desde o Onze de Setembro, as circunstâncias já não são normais. Estamos nos afogando em uma onda de retórica política a respeito dos perigos terríveis e desconhecidos que vêm do estrangeiro - a histeria das armas de destruição em massa, a inadequadamente chamada 'guerra contra o terrorismo' e a 'defesa do nosso estilo de vida' - e contra inimigos externos mal definidos e seus agentes terroristas internos. Tratase de uma retórica que visa mais arrepiar os cabelos dos cidadãos do que enfrentar o terror - com objetivos que deixou a vocês a tarefa de identificar, pois arrepiar os cabelos e criar o pânico é exatamente o que os terroristas querem fazer.

Ainda segundo Hobsbawm ${ }^{24}$, essa histeria era evidente porque a

"chamada contra o terror" não é uma guerra, exceto no sentido metafórico [...]. O terrorismo requer esforços especiais, mas é importante não perdermos a cabeça ao desenvolvê-los. [...]. Na prática, o perigo real do terrorismo não está no risco causado por alguns punhados de fanáticos anônimos, e sim no medo irracional que suas atividades provocam e que hoje é encorajado tanto pela imprensa quanto por governos insensatos. Esse é um dos maiores perigos do nosso tempo, certamente maior do que o dos pequenos grupos terroristas ${ }^{25}$.

Vale acrescentar a essa descrição que a guerra contra o terror era fundamentada em elementos maniqueístas ao elencar Estados que formariam um "eixo do mal", incutindo ao mesmo tempo uma sensação ampliada da ameaça de um ataque ainda mais devastador, caso cometido com armas de destruição em massa, e justificando o reforço do interesse nacional em manter suas políticas nucleares sedimentadas ao longo da Guerra Fria.

23 HOBSBAWM, Eric. A ordem pública em uma era de violência. In: Globalização, democracia e terrorismo. Tradução de José Viegas. São Paulo: Companhia das Letras, 2007, p. 149.

24 Ibidem, p. 151.

25 Reforçando a crítica de que a guerra contra o terror não é uma guerra, ver: LOUKA, Ellie. Nuclear Weapons, Justice and the Law. Cheltenham: Edward Elgar, 2011, p. 6, tradução livre do original em inglês: "A guerra contra os terroristas lançada no Afeganistão e no Paquistão possui todos os elementos de um conflito não convencional. Nessa guerra, um ambiente natural desfavorável e a liderança do Taleban conseguiram envolver os Estados Unidos e seus aliados num conflito sem um fim avistável’. 
No que tange ao tema objeto de análise no presente trabalho, a retórica política que exacerbava a histeria em relação às armas de destruição em massa em meio à declarada "guerra contra o terror" acabou sendo trazida para o cerne das políticas de segurança nacional norte-americana, como foi mencionado na parte 1 , capítulo 2 , da dissertação ${ }^{26}$, com a insistente repetição de que as armas nucleares desempenham um papel central na definição da política externa do país, caráter visto como permanente em longo prazo.

Independentemente das reações que naturalmente adviriam de um ataque de tão terríveis proporções, não fica claro, como foi antecipado na introdução deste capítulo, até que ponto essa exacerbação política em relação às armas nucleares e seu papel na guerra contra o terror é uma resposta cabível e adequada, ou é simplesmente um uso oportunista do contexto político ocasionado pelos atentados.

Em primeiro lugar, porque existem peculiaridades em torno da obtenção e manutenção desse tipo de armamento que tornam extremamente difícil que grupos não estatais reúnam as condições logísticas e financeiras para adquiri-lo ${ }^{27}$. É muito pouco crível, inclusive, que algum Estado pudesse apoiar ou mesmo tolerar uma iniciativa de um grupo terrorista visando à obtenção de uma arma atômica, considerando que as atividades para a produção de uma dessas bombas dificilmente poderiam ser mantidas clandestinamente, porque "nenhum país ousaria ter seu nome associado à montagem de uma bomba atômica independente pelo medo da certeza de represália"28.

Mesmo no que toca à ameaça posta pelas “armas perdidas" (loose nukes), especialmente aquelas que se acredita que estejam ou estavam mais facilmente disponíveis nos antigos arsenais soviéticos, situados numa região geograficamente fragmentada e instável, uma vez que as armas nucleares requerem intensa e constante manutenção,

26 U.S.A. Department of Defense and Department of Energy of United States of America. National Security and Nuclear Weapons in the 21st Century. Feb. 2008. Disponível em: http://www.defense.gov/news/nuclearweaponspolicy.pdf. Acesso em: 16 nov. 2014., e U.S.A. Seal of the President of the United States. National Security Strategy. May 2010. Disponível em: http://www.whitehouse.gov/sites/default/files/rss_viewer/national_security_strategy.pdf. Acesso em: 16 nov. 2014.

27 RAMINA, Larissa; CUNHA FILHO, Valter Fernandes da, Segurança internacional. Curitiba: Juruá, 2013, p. 160. Na realidade, em relação ao uso terrorista de material atômico, o temor reserva-se mais em relação às chamadas bombas sujas, que não possuem o potencial destrutivo das bombas atômicas, mas propiciam a dispersão de elementos radioativos. Essas armas são relativamente menos elaboradas quanto à fabricação e demandam logística de uso extremamente simplificada. Cf. LOUKA, Ellie, Nuclear Weapons, Justice and the Law. Cheltenham: Edward Elgar, 2011, p. 20.

28 LANGEWIESCHE, William. O bazar atômico. Tradução de José Viegas. São Paulo: Companhia das Letras, 2007, p. 72. 
qualquer dessas bombas hoje estaria "transformada em cacareco". As limitações temporais para o uso de uma arma eventualmente roubada "são bem conhecidas, e a própria ausência de um ataque nuclear terrorista até aqui é indício de que nada de útil foi efetivamente roubado" 29 .

Além disso, é diminuto o risco de armas serem roubadas de arsenais de Estados nuclearmente armados, devido ao elevado nível de segurança imposto pelos respectivos governos, ao qual se sobrepõe, como observado no capítulo 5, da segunda parte do trabalho, um regime de obrigações internacionais robustecendo os sistemas de segurança e corrigindo eventuais falhas. Deve ser ainda acrescentado, como incentivo para um bom aprimoramento dos sistemas de segurança nacional, o temor de que, em caso de uso de uma de suas armas em um atentado, pudesse existir “a impressão de um Estado estar usando terceiros para fazer guerras nucleares" ${ }^{, 30}$, circunstância que os colocaria sob o risco de retaliação nuclear.

Em segundo lugar, é altamente questionável a tentativa de aplicar a política de dissuasão nuclear com relação à ameaça terrorista, diante da ausência de identificação nacional dos grupos insurgentes com o Estado que os abriga, ou que é refém de um deles. Essa ausência de identidade nacional corrói a possibilidade de as armas nucleares dissuadirem eventuais insurgentes contra seu uso porque, mesmo que se retaliasse nuclearmente um atentado atômico, o país retaliado seria destruído fisicamente, mas não necessariamente o grupo terrorista, cuja rede é geralmente fluida, com facilidade de deslocamento entre vários Estados. Um dado que ilustra essa característica é o de que, entre os trezentos guerrilheiros talebans que foram presos em Guantánamo, verificaram-se 28 nacionalidades distintas ${ }^{31}$.

Por isso, mesmo que fosse possível superar os grandes obstáculos práticos para que um grupo terrorista reunisse as condições de perpetrar um ataque atômico, ainda assim a manutenção das armas nucleares pelas principais potências não seria justificável. Na eventual hipótese de um grupo interceptar uma arma que seja, e utilizá-la sem apoio ou incentivo de qualquer Estado, não se verificaria a possibilidade de a dissuasão nuclear

29 LANGEWIESCHE, William. O bazar atômico - a escalada do poderio nuclear. Tradução de J. Viegas. São Paulo: Cia das Letras, 2007, p. 25.

30 Ibidem, p. 25.

31 MARTINS, Luciano. A (des)ordem mundial. In: DUPAS, Gilberto; LAFER, Celso; SILVA, Carlos Eduardo Lins da (Orgs.). A nova configuração mundial do poder. São Paulo: Paz e Terra, 2008, p. 205. 
funcionar, simplesmente porque esse grupo terrorista geralmente não possuiria "nenhuma instalação permanente de infraestrutura para proteger, nenhuma cidade capital, nem mesmo um país a que possam chamar de terra natal"32.

Não fossem esses elementos que refutam a possibilidade de a dissuasão nuclear operar adequadamente contra o terrorismo internacional, seria muito difícil a superação de entraves jurídicos para permitir uma retaliação nuclear contra um atentado terrorista dessa natureza, como descreve More:

O primeiro entrave jurídico seria proporcionalidade da resposta (da retorsão), já que armas nucleares, assim como as armas químicas e biológicas, não distinguem entre terroristas e civis. O segundo seria a identificação dos responsáveis, nomeadamente governos, não Estados, em conexão ou não com terroristas, como foi o caso do governo Taleban no Afeganistão em relação aos terroristas da Al-Qaeda: como punir o Governo sem punir o Estado? ${ }^{33}$

Esses aspectos que tornam altamente questionável a legitimidade do discurso norteamericano com relação à manutenção de seus arsenais atômicos para conter o risco posto pelo terrorismo internacional são reconhecidos inclusive por outras potências nucleares. É digno de nota o questionamento cínico de Putin, feito à época da suspeita de terem sido usadas armas químicas na guerra civil síria que se desenrola nos últimos anos:

Mas surgem outras perguntas. Se ficar demonstrado que a guerrilha usou armas químicas, o que os EUA farão com os guerrilheiros? Que farão com os guerrilheiros seus patrocinadores? Deixarão de fornecer-lhes armas? Lançarão operações militares contra eles? ? $^{34}$

32 MARTINS, Luciano. A (des)ordem mundial. In: DUPAS, Gilberto; LAFER, Celso; SILVA, Carlos Eduardo Lins da (Orgs.). A nova configuração mundial do poder. São Paulo: Paz e Terra, 2008, p. 22. Vale ressalvar que existem grupos insurgentes de liberação nacional, os quais teriam, efetivamente, aspectos geopolíticos, como território e população, que eventualmente os situariam num plano funcional da dissuasão nuclear.

33 MORE, Rodrigo Fernandes. O desarmamento no sistema de segurança coletiva da ONU. 2005. Tese (Doutorado) - Faculdade de Direito, Universidade de São Paulo, São Paulo, 2002, p. 31.

34 RÚSSIA diz aceitar ação militar na Síria se uso de armas químicas for provado. Folha de São Paulo. 4 set. 2013. Disponível em: <http://www1.folha.uol.com.br/mundo/2013/09/1336646-russia-diz-aceitaracao-militar-na-siria-se-uso-de-armas-quimicas-for-provado.shtml>. Acesso em: 4 set. 2013. 
Torna-se extremamente suspeita, portanto, a retórica adotada nos níveis doméstico e internacional depois dos atentados terroristas de 2001, aparentemente numa lamentável e oportunista intenção de utilizá-los como instrumento para encontrar um novo fundamento ideológico, capaz de justificar o reiterado descumprimento norte-americano da obrigação de se desarmar conforme estabelecido no TNP, assim como as demais condutas alinhadas a esse descumprimento, anteriormente descritas ao longo da presente dissertação.

A adoção propagandística de discursos das autoridades sobre ameaças generalizadas é usual para a obtenção da legitimação de atos que, sem o medo que acaba autorizando abusos num "mundo em que as pessoas perdem a capacidade de julgar, pois tudo tem uma explicação", não passariam ilesos perante a opinião pública ${ }^{35}$. Nesse sentido, é precisa a lição de João Bernardo:

Os jornais, não só os de escândalos, mas também muitos dos que se pretendem sérios, a televisão e o cinema prosseguem sistematicamente uma indústria acerca da qual não são reunidas estatísticas, mas que decerto atinge cifras astronômicas, e cujo objetivo é apenas provocar uma sensação de medo. É curioso verificar - um exemplo entre muitos - que na Grã-Bretanha, nos últimos anos, o declínio do número de crimes realmente cometidos tem sido acompanhado de inquéritos de opinião pelo aumento da percentagem de pessoas convictas de que os crimes se têm generalizado. No início da época romântica o terror havia constituído o elemento determinante do sublime, mas ele assume agora funções mais prosaicas, legitimando a omnipresença de uma polícia oculta. [...]

Em resumo, os acontecimentos de 11 de setembro de 2001 forneceram o pretexto para legitimar a rede de fiscalização eletrônica dos trabalhadores nas empresas e dos cidadãos comuns durante os ócios, que estava já montada antes daqueles atentados e que, aliás, em nada serviu para impedi-los. Continuando possivelmente a ser tão inoperante como até agora foi relativamente aos terroristas - quem quer que seja assim classificado - a fiscalização eletrônica terá como primeiro, e talvez único, resultado submeter a população a níveis de controle cada vez maiores. ${ }^{36}$

Acompanhando o quadro destacado pelo cientista político luso sobre o uso distorcido de estatísticas para fomentar esse discurso do medo, torna-se espantoso identificar que "houve muito mais mortes de americanos em desastres de automóvel provocados por

35 Elemento importante para o cenário internacional, como descrito no capítulo 3 da primeira parte do trabalho.

36 BERNARDO, João. A democracia totalitária. São Paulo: Cortez, 2004, p. 155-162. 
veados, em 2013, do que pela ação de terroristas" ${ }^{\text {37 }}$. Se, no lugar da retórica do terror, esse dado fosse estampado em manchetes, no mínimo se poderia esperar uma maior reflexão em torno da efetividade das justificativas norte-americanas para sua política nuclear.

Muito mais eficaz do que a exacerbação do medo e do ódio, calcados no maniqueísmo da guerra contra o terror, é recorrente a percepção de que, para a redução do risco de um ataque terrorista nuclear, seria muito mais produtiva a adoção de medidas mais profundas no que concerne à cooperação internacional, diametralmente oposta ao unilateralismo descrito nestas páginas.

Essa cooperação pode ser compreendida mesmo nos esforços bilaterais pela redução e corte de armamentos, especialmente as armas classificadas como táticas ${ }^{38}$. Ainda que seja considerado pequeno o "risco de uma bomba nuclear vir a ser roubada ou comprada", para se reduzir ainda mais esse risco deveria haver uma diminuição, ou até banimento das armas táticas. Segundo Hans Blix, "os americanos e os russos deveriam desmontar a totalidade de seu arsenal de armas táticas nucleares de pequeno porte porque elas não são grandes a ponto de não poderem ser levadas, e estão espalhadas por um grande número de pontos de armazenamento" 39 .

Ao lado desse esforço bilateral, a cooperação internacional multilateral representaria, no lugar do acirramento do unilateralismo, um modo muito mais efetivo de encarar a ameaça terrorista. Essa constatação decorre da percepção franca de que é quase impossível garantir a segurança completa contra terroristas suicidas que não têm limites em termos de audácia, imaginação e crueldade. Não se deve, por isso, privilegiar uma luta irreal e desenfreada pela segurança sacrificando valores tão caros como liberdade e justiça, razão pela qual uma coalizão global para combater o terrorismo não deveria restringir-se apenas

37 FRIEDMAN, Thomas L. O presente eterno. O Estado de São Paulo, São Paulo, 4 dez. 2014, A19.

38 Há inúmeras referências que destacam o perigo que essas armas táticas representam, uma vez que, por possuírem menor potencial destrutivo, acabam tendo considerações mais plausíveis de uso efetivo em combate. Ocorre que, em todas as simulações de guerra, seu uso sempre acarreta escalada generalizada que culmina no conflito catastrófico para a humanidade. Por isso, o desmantelamento das 'tactical nukes' é um objetivo concreto e viável que, ademais, vai ao encontro da obrigação prevista no art. VI, do TNP. Cf. BUNDY, McGeorge; CROWE JR., William J.; DRELL, Sidney D. Reducing Nuclear Danger - The Road Away from the Brink. New York: Council on Foreign Relations Press, 1993, p. 31; ZUCKERMAN, Solly. Nuclear Illusion and Reality. New York: The Viking, 1982p. 67-68; e Committee on International Security and Arms Control - National Academy of Sciences, The future of the U.S. - Soviet nuclear relationship. Washington: National Academy, 1991, p. 22-23.

39 BLIX, Hans. Questões sobre a Guerra do Iraque: o uso de força, armas de destruição em massa e as Nações Unidas. In: DUPAS, Gilberto; LAFER, Celso; SILVA, Carlos Eduardo Lins da (Orgs.). A nova configuração mundial do poder. São Paulo: Paz e Terra, 2008, p. 338. 
a metas punitivas e retaliatórias, mas sim se envolver numa causa mais ampla de robustecer a segurança em escala mundial ao fortalecer estruturas de cooperação em longo prazo, as quais poderão ter o efeito de auxiliar Estados frágeis a superarem desafios em termos de desenvolvimento ${ }^{40}$.

Essa mesma visão é defendida pelo já citado Hans Blix, que afirma que

o caminho para evitar o terrorismo internacional passa pela cooperação entre os Estados em diversos aspectos - policial, sistema bancário, serviços de inteligência - sendo que a providência mais básica é tentar evitar o surgimento de um território fértil para o terrorismo. A ação política e social é de vital importância para reduzir as queixas que sirvam de estímulo ao terrorismo".

Como argumento definitivo, o ex-diretor da AIEA reconhece que "a ação armada no Iraque, em 2003, pretendia ser um golpe no terrorismo, mas, lamentavelmente, acabou por incentivá-1o",41.

Essas breves considerações sobre o terrorismo internacional permitem identificar o erro de se prestigiarem apenas o medo e a busca por garantias de segurança para lidar com essa ameaça. Tais garantias são difíceis ou mesmo impossíveis de serem obtidas, e o meio mais eficaz de confrontar o terrorismo, como foi visto, é justamente o fortalecimento dos Estados falidos e de estruturas extremamente frágeis, aprimorando-se suas condições sociais e econômicas para, assim, reduzir drasticamente as condições mais férteis para o surgimento de movimentos insurgentes.

Além disso, parece evidente a fragilidade do discurso que tenta justificar a manutenção de arsenais atômicos numa tentativa de replicar a dissuasão nuclear contra o terrorismo internacional. Como foi observado, a ameaça de retaliação é esvaziada pela ausência de um Estado a ser atacado em resposta, e há barreiras jurídicas muito difíceis de se contornarem para autorizar uma represália nuclear a ser realizada por eventual vítima ou por aliança de proteção internacional a que eventualmente pertença.

40 THAKUR, Ramesh. An International Perspective on Global Terrorism in War in Our Time - Reflections on Iraq, Terrorismo and Weapons of Mass Destruction. Tokyo: United Nations University, 2007, p. 1314.

41 BLIX, Hans. Questões sobre a Guerra do Iraque: o uso de força, armas de destruição em massa e as Nações Unidas. In: DUPAS, Gilberto; LAFER, Celso; SILVA, Carlos Eduardo Lins da (Orgs.). A nova configuração mundial do poder. São Paulo: Paz e Terra, 2008, p. 339. 
Por essas razões, diferentemente da prática verificada atualmente, deveria haver uma verdadeira guinada nas políticas de defesa para conter o terrorismo internacional, que seria enfrentado de modo muito mais eficaz caso adotadas medidas de cooperação positiva internacional, a qual propiciaria inclusive a evolução para patamares mais elevados de confiança entre os Estados, um passo essencial para a construção da paz, como propugnado por Kant em seu ensaio sobre a paz perpétua.

Essa mesma necessidade de uma alteração qualitativa deve ser aplicada no modo como os Estados vêm tentando lidar contra as recentes ameaças de proliferação nuclear, sendo muito interessante notar que as respostas usualmente dadas, em vez de lograrem êxito para conter âmbitos nucleares de proliferadores ou potenciais proliferadores, acabam empurrando-os para aprofundarem suas iniciativas. É o que será analisado no próximo tópico.

\subsection{As respostas contra proliferadores incentivando a proliferação nuclear}

\subsubsection{Sanções com questionável utilidade}

Ao lado do terrorismo internacional, conforme observado na introdução deste capítulo, um aspecto contemporâneo que compõe o quadro de ameaças no cenário do pósGuerra Fria é um crescente número de países com intuitos voltados ao desenvolvimento de programas nucleares, às vezes declaradamente com fins estratégicos militares.

Assim como observado nas respostas dadas pelos Estados contra a ameaça do terrorismo internacional, o risco posto por esses países rotulados como proliferadores também é usualmente confrontado por meio de medidas que privilegiam quase que exclusivamente os aspectos da segurança internacional. Quando aqui se alude ao conceito de segurança, imediatamente convém relembrar as críticas feitas contra essas medidas, uma vez que as dúvidas sobre "a quem pertencia a segurança em questão, e à custa de quem ela é obtida"42 não pendem a favor dos Estados menos poderosos no tabuleiro internacional.

42 WIGHT, M. A política do poder. Tradução de C. S. Duarte. Brasília: Editora Universidade de Brasília, 1985 , p. 32. 
Nesse prisma, as respostas dadas internacionalmente contra os Estados proliferadores têm sido pautadas sempre por sanções e embargos econômicos e de tecnologia, acompanhadas de enorme isolamento e retórica difamatória, quando, não raro, de ameaças de ataques militares propriamente ditos.

Caso esse conjunto de medidas se mostrasse eficaz, ainda que criticável sob o ponto de vista do viés discriminatório do TNP e do regime de não proliferação que engendra, poder-se-ia aceitá-lo sob o argumento da segurança internacional, já que, como foi visto na primeira parte desta dissertação, se a dissuasão já era falha e instável quando praticada apenas entre poucos atores nucleares, o espraiamento de arsenais atômicos para diversos Estados ampliaria enormemente os riscos da falência dessa prática.

Entretanto, tampouco o teste da eficácia apresenta algum argumento favorável a esse conjunto de respostas internacionais meramente punitivas. $\mathrm{O}$ mundo pouco pode fazer contra o desenvolvimento dos programas nucleares indiano, paquistanês e israelense e, mais recentemente, vem colecionando dificuldades e contratempos na luta para evitar que a Coreia do Norte e o Irã ingressem no clube atômico.

Pelo êxito da iniciativa norte-coreana, esta será utilizada para descrever a dinâmica de encontros e desencontros que culminou com sua retirada do TNP, sucedida da realização de testes atômicos que demonstrou sua conquista de armas nucleares.

Apesar de seu isolamento internacional, a postura da Coreia do Norte em relação às armas nucleares poderia ser considerada como alinhada ao regime da não proliferação, tendo se tornado parte do TNP em $1985^{43}$, e se afirmado muito contrariamente às armas atômicas durante os trabalhos preparatórios perante a Corte Internacional de Justiça por conta da opinião consultiva sobre a legalidade do uso ou da ameaça de uso de armas nucleares, conforme observado no capítulo anterior.

Entretanto, em 1994, diante da descoberta de que aquele país possuía um reator nuclear movido a grafite, cuja tecnologia permite mais meios de se ludibriarem os

43 UNODA (United Nations Office for disarmament affairs). Treaty on the Non-Proliferation of Nuclear Weapons. Opened for signature at London, Moscow and Washington: 1 July 1968. Disponível em: http://disarmament.un.org/treaties/t/npt. Acesso em: 9 dez. 2014. 
mecanismos de inspeção da AIEA, foram realizadas negociações em Genebra que culminaram num acordo com os Estados Unidos ${ }^{44}$.

Segundo o entendimento alcançado pelas partes, seria abandonado o plano de desenvolvimento de um programa nuclear nacional em troca de ampla assistência internacional, incluindo o envio de 500 mil toneladas de petróleo por ano, o abrandamento de restrições comerciais e, até 2003, para substituir o reator nuclear pivô do burburinho internacional, a construção e instalação de dois reatores nucleares de $1000 \mathrm{MW}$, cuja tecnologia poderia ser adequadamente submetida ao sistema de salvaguardas da AIEA.

Esse acordo, mesmo constituído por medidas cooperativas que poderiam propiciar um desenvolvimento daquele país, meta que, se atingida, poderia abrandar a avaliação estratégica que atribuía à posse de armas nucleares um elemento de afirmação internacional, foi bastante criticado. Num primeiro aspecto, porque, sendo a Coreia do Norte membro do TNP, sua ameaça de descumprir as obrigações previstas no tratado, no lugar de ser reprimida, foi recompensada, o que poderia motivar outras nações a seguirem o mesmo caminho.

Além disso, como o prazo para a entrega dos dois novos reatores era de quase uma década, esse seria o tempo até que fosse possível a imposição do sistema de salvaguardas da AIEA, prazo em que o país poderia desviar material físsil (plutônio) de seu reator em operação, mantendo seu programa nuclear bélico. Nesse sentido, era preocupante observar as constantes dificuldades impostas pelo país na verificação do respeito aos termos do acordo celebrado com os americanos, conforme resumido em registro dos desdobramentos desenvolvido pela $\mathrm{BBC}^{45}$.

Não por coincidência, um ano antes do prazo previsto no acordo para o término da construção dos dois reatores "salvaguardáveis", os Estados Unidos denunciaram que a Coreia do Norte teria admitido a existência de um programa secreto de armas nucleares, na mesma ocasião em que o país declarou sua intenção de se retirar do TNP. Foi quando a

\footnotetext{
${ }^{44}$ IAEA. Information circular. Agreed framework of 21 October 1994 between the United States of America and the Democratic People's Republic of Korea. Disponível em: <http://www.iaea.org/sites/default/files/publications/documents/infcircs/1994/infcirc457.pdf>. Acesso em: 17 nov. 2014.

45 Disponível em: <http://news.bbc.co.uk/2/mobile/asiapacific/7265679.stm>, Acesso em: 17 nov. 2014.
} 
Coreia do Norte expulsou inspetores nucleares da AIEA do país, afirmando suas intenções de reabrir sua planta de reprocessamento de combustível nuclear para a obtenção de plutônio compatível com as necessidades militares num período de poucos meses ${ }^{46}$.

Em 2006, as aspirações nucleares norte-coreanas foram confirmadas, quando oficiais da inteligência americana anunciaram que amostras de ar coletadas no local onde teria sido feito um teste atômico continham materiais radioativos, confirmando que o país havia realizado uma explosão nuclear subterrânea de aproximadamente um quiloton ${ }^{47}$.

A reação imediata do Conselho de Segurança da ONU foi aprovar uma resolução determinando à Coreia do Norte o abandono de seu programa nuclear de modo completo, verificável e irreversível, o respeito a suas obrigações assumidas sob o regime do TNP e às condições do acordo de salvaguardas da AIEA, e impondo pesadas sanções, como o embargo financeiro-econômico de materiais para armamentos convencionais e nucleares, e o congelamento de fundos e aplicações financeiras mantidas por pessoas físicas e instituições ligadas ao programa armamentista ${ }^{48}$.

Diante da insistência norte-coreana em se manter fora do regime do TNP, em 2009, o Conselho de Segurança aprovou a Resolução 1887, a qual apontava a experiência daquele país como motivo para determinar mudanças no tratado, especialmente para alterar as formalidades para sua denúncia, tornando mais difícil o exercício do direito de retirada ${ }^{49}$.

A partir daí foram renovadas e ampliadas as sanções contra a Coreia do Norte, mas, ainda assim, apenas o que se viu foi um aprimoramento de seu programa nuclear. Em ferreiro de 2013, o país realizou seu terceiro teste nuclear em sete anos, refletindo o fracasso da tentativa internacional,

a começar dos EUA, de travar a longa marcha de Pyongyang rumo ao clube atômico. As três rodadas de sanções já impostas pelo Conselho de Segurança da ONU, talvez por se concentrarem nas atividades nucleares e

46 Disponível em: <http://news.bbc.co.uk/2/mobile/asiapacific/7265679.stm>, Acesso em: 17 nov. 2014.

47 Ibidem.

48 UNITED NATIONS. Resolution 1718 (2006). Adopted by the Security Council at its 5551st meeting, on14 October 2006. Disponível em: <http://www.un.org/ga/search/view_doc.asp?symbol=S/RES/1718\%20(2006)>. Acesso em: 6 dez. 2014.

49 UNITED NATIONS. Resolution 1887 (2009). Adopted by the Security Council at its 6191st meeting, on 24 September 2009. Disponível em: <http://www.un.org/en/ga/search/view_doc.asp?symbol=S/RES/1887(2009)>. Acesso em: 6 dez. 2014. 
missilísticas norte-coreanas, não retardaram, muito menos bloquearam o desenvolvimento de sua tecnologia bélica. Pior ainda, deram ao regime pretexto para persistir nas mesmas ações que tentam reprimir. [...] $\mathrm{O}$ próprio argumento em favor de sanções mais abrangentes tem contra si a força dos fatos ${ }^{50}$.

A combinação das sanções com as ameaças cada vez mais concretas de ataque militar contra o país apenas o empurrava cada vez mais para seu isolacionismo nuclear. Basta verificar que, poucos meses depois desse teste e das ameaças feitas por diversos Estados em razão dele, em abril de 2013 se noticiava o acirramento do contexto político da península coreana, depois da aplicação, pela ONU,

de duras sanções contra o governo norte-coreano após o país ter realizado seu mais recente teste nuclear, às quais o governo norte-coreano respondeu com ameaças de usar armas nucleares contra o sul-coreano e os americanos, depois de os Estados Unidos terem enviado aviões de guerra para a nação vizinha ${ }^{51}$.

Vê-se, pela experiência norte-coreana, que as sanções que passaram a se enrijecer gradativamente desde o descumprimento, pelo regime de Pyongyang, do acordo celebrado com os americanos em 1994 não surtiram o efeito de demover o país de sua pretensão nuclear. Menos de uma década depois, ele havia adquirido capacidade atômica, a qual o autorizava inclusive a deflagrar retórica de ameaça de ataques com armas nucleares contra a vizinha Coreia do Sul, o Japão e os próprios Estados Unidos, algo não muito diferente do que ocorre na prática da dissuasão nuclear entre as principais potências.

É possível afirmar, a partir dessas considerações, que a aplicação de sanções punitivas sem o acompanhamento de medidas de inserção de pretenso proliferador ao regime internacional por meio da cooperação social política, que poderia reinseri-lo no regime de não proliferação, apenas possui o efeito deletério de reforçar o seu interesse estratégico de obter armas nucleares, funcionando como pretexto para sua persistência nos mesmos atos que as sanções tentam reprimir.

\footnotetext{
50 A provocação de Pyongyang. O Estado de São Paulo, São Paulo, 14 fev. 2013, A3.

${ }^{51}$ COREIA DO NORTE é acusada de estar preparando teste nuclear. BBC Brasil. 8 abr. 2013. Disponível em: <http://www.bbc.co.uk/portuguese/ultimas_noticias/2013/04/130408_coreia_ataque_bg_rn>. Acesso em: 4 dez. 2014.
} 
Esses pretextos tornam-se ainda mais evidentes quando se identifica que tem sido cada vez mais recorrente a retórica permissiva em relação ao direito à autodefesa previsto no artigo 51 da Carta da ONU, numa tentativa de ampliá-lo para compreender também a prerrogativa de um Estado agir preventivamente contra possíveis proliferadores. Essa ameaça, especialmente quando se lembra o que ocorreu com o Iraque, que se submeteu às inspeções da AIEA, se desarmou e ainda assim foi invadido sob a alegação de possuir armas de destruição em massa, apenas tem o efeito de reforçar o interesse de pretensos proliferadores a de fato adquirirem capacidade atômica bélica o quanto antes.

\title{
4.2.2 Autodefesa e guerra preventiva - mais incentivos à proliferação
}

A questão da guerra preventiva, segundo Bull, ilustra perfeitamente o "choque entre imperativos derivados do direito internacional e exigências relacionadas com o princípio de que um equilíbrio de poder deve ser mantido". Segundo o autor,

\begin{abstract}
a maior parte dos textos sobre o direito internacional sustentam que a guerra preventiva é ilegal. [...] No entanto, as exigências do equilíbrio de poder indicam a possibilidade de que seja necessário fazer a guerra contra um estado cujo poder relativo esteja crescendo de modo a ameaçar esse equilíbrio, ainda que ele não seja responsável por qualquer agressão cometida contra um membro da sociedade internacional $^{52}$.
\end{abstract}

A guerra preventiva, nesse aspecto, pode ser considerada como a manifestação mais recente da prática internacional que tenta relativizar a estrita hipótese em que o conflito armado é autorizado pela Carta da ONU, interpretando o direito do exercício à autodefesa como um conceito elástico, conforme descreve Louka:

A prática dos Estados tem demonstrado que o direito à autodefesa vem sendo interpretado expansivamente para incluir mais do que uma resposta contra um ataque armado imediato; tem sido interpretado também para incluir a autodefesa antecipatória e preventiva ${ }^{53}$.

Vale ainda acrescentar que a autora descreve a autodefesa preventiva como um lado escorregadio da dissuasão, presente quando esta falha. Esse lado escorregadio tem sido

52 BULL, Hedley.A sociedade anárquica. Tradução de Sergio Bath. Brasília: UnB/IPRI, 2002, p. 165-166.

53 LOUKA, Ellie. Nuclear Weapons, Justice and the Law. Cheltenham: Edward Elgar, 2011, p. 194. 
verificado em diversas estratégias de segurança nacionais contra Estados e atores não estatais que dificilmente são persuadidos pela dissuasão, especialmente depois dos ataques de 11 de setembro, fomentando inclusive ataques e operações como precaução mesmo antes de que proliferadores se tornem ameaças reais ${ }^{54}$.

Ainda que se compreenda a justificativa desses ataques preventivos como um meio de manutenção do atual estado do equilíbrio de poder, segundo Ott, aceitar a legitimidade dessa reivindicação demanda, indispensavelmente, que o país que venha a efetuá-los esteja agindo com uma base inatacável de honestidade e boa-fé. Não apenas devido à subjetividade que sempre marca esse tipo de avaliação, mas também ao viés discriminatório do regime de não proliferação, que se torna mais inaceitável diante da recusa dos Estados nuclearmente armados de cumprirem sua contrapartida de desarmamento prevista no TNP, a autodefesa preventiva se revela não confiável, e, como demonstrado historicamente, perigosamente aberta a abusos por Estados que apenas buscam uma desculpa para atacar nações mais fracas em vez de negociar com elas. Esse comportamento não apenas excede os limites do artigo 51 da Carta da ONU, mas ainda representa violação dos artigos 2(3) e 2(4), que afastam a possibilidade de os Estados resolverem controvérsias por meio de ataques $\operatorname{armados}^{55}$.

Por isso, Soares afirmava que

a partir do exame das normas do Direito Internacional atualmente vigentes, não há qualquer possibilidade de existir uma guerra preventiva que seja legítima, entendendo-se guerra, na sua acepção mais corrente, como um uso efetivo ou uma ameaça de uso das Forças Armadas por um Estado ou por um grupo de Estados, nas relações internacionais da atualidade ${ }^{56}$

Essa incompatibilidade com as normas internacionais é ainda mais deletéria para o fomento de uma convivência pacífica e harmônica, por sua combinação assustadora com

54 LOUKA, Ellie. Nuclear Weapons, Justice and the Law. Cheltenham: Edward Elgar, 2011, p. 35-37.

55 OTT, David H. Public International Law in the Modern World. Londres: Pitman, 1987, p. 312.

56 SOARES, Guido Fernando Silva. Legitimidade de uma guerra preventiva? In: DUPAS, Gilberto; LAFER, Celso; SILVA, Carlos Eduardo Lins da (Orgs.). A nova configuração mundial do poder. São Paulo: Paz e Terra, 2008, p. 276. 
serviços de inteligência que funcionem mal, ou que estejam manipulados por interesses específicos inconfessáveis ${ }^{57}$.

Apesar dessas críticas, houve recentes ataques de tal natureza. Em 2007, Israel atacou e destruiu o que, à época, suspeitava-se um pretenso reator nuclear na Síria, localizado em Al Kibar. Israel não admitiu nem negou a responsabilidade pelo ataque, conduzido de maneira secreta. No ano seguinte, foram coletadas amostras ambientais por inspetores da AIEA, cuja análise revelou a presença de urânio manipulado pelo homem, fortalecendo as suspeitas de que a Síria estivesse desenvolvendo um programa secreto de $\operatorname{armas~nucleares~}^{58}$.

Não se tratava da primeira investida israelense dessa natureza, sendo notório o ataque cometido em 1981 contra o reator situado em Osiraq, no Iraque. À época, depois de efetuado o ataque, o país foi alvo de diversas reprimendas internacionais, tendo sido aprovada, nesse sentido, a Resolução 487 Conselho de Segurança ${ }^{59}$. Uma década depois, na guerra do Iraque de 1991, esse ataque provavelmente foi lembrado, e, ainda mais provável, celebrado pelas forças da coalizão que agiram sob os auspícios da ONU.

Há algumas diferenças notáveis entre os dois ataques. O reator de Osiraq era submetido ao regime de inspeções da AIEA, circunstância que certamente contribuiu para a condenação internacional de Israel. Já o reator de Al Kibar era clandestino, nunca tendo sido declarada sua existência para a AIEA ou qualquer outro órgão internacional, elevando as suspeitas quanto às efetivas intenções sírias. Além disso, diferentemente do ataque de 1981, Israel, conforme observado, não declarou nada a respeito do ataque contra a Síria, talvez para tentar evitar uma retórica condenatória no plano internacional.

Essa vagueza israelense em relação à responsabilidade pelo ataque foi seguida do espantoso fato de que não houve condenação pública internacional, não existindo sequer registro de repúdio por qualquer Estado árabe, ou mesmo pelo Irã, o que pode ser lido como um alívio internacional frente à paralisação de uma tentativa nuclear clandestina da

57 BLIX, Hans. BLIX, Hans. Questões sobre a Guerra do Iraque: o uso de força, armas de destruição em massa e as Nações Unidas. In: DUPAS, Gilberto; LAFER, Celso; SILVA, Carlos Eduardo Lins da (Orgs.). A nova configuração mundial do poder. São Paulo: Paz e Terra, 2008, p. 348.

58 LOUKA, Ellie. Nuclear Weapons, Justice and the Law. Cheltenham: Edward Elgar, 2011, , p. 151.

59 UNITED NATIONS. Resolution 487 (1981). Adopted by the Security Council at its 2288st meeting, on 19 June $1981 . \quad$ Disponível em: <http://unispal.un.org/unispal.nsf/d744b47860e5c97e85256c40005d01d6/6c57312cc8bd93ca852560df00 653995>. Acesso em: 7 dez. 2014. 
Síria $^{60}$. Ainda mais espantoso foi verificar que, se algum país passou a sofrer sanções ou ameaças de sanções, este país foi a própria Síria, já que, com a revelação de sua iniciativa clandestina, foi aberta severa investigação internacional contra suas atividades proliferadoras, com a imposição da transparência integral descrita no capítulo 2 da terceira parte da dissertação ${ }^{61}$.

A reação internacional contra esse ataque, diametralmente oposta à condenação que se tinha seguido na década de 1980, permite considerar que esse tipo de ataque secreto cirúrgico, com reduzidíssimas baixas civis ou mesmo militares, se tornará cada vez mais comum, em que os ataques preventivos, mesmo ilegais, serão tolerados como algo razoável e legitimado.

Esse dado recente representa uma perigosa mudança no plano das relações internacionais com elevadíssimo potencial de incentivar a aquisição de armas nucleares por diversos países, especialmente quando se verifica que esses ataques foram realizados por um Estado que se acredita possuir capacidade nuclear bélica. Essa consequência negativa assume contornos mais preocupantes à medida que o ataque israelense ocorreu numa região do globo em que as relações políticas sabidamente hostis entre o Irã, os Estados Unidos e Israel alimentam a necessidade iraniana de adquirir, o quanto antes, capacidades de dissuasão, inclusive nuclear ${ }^{62}$.

No caso iraniano, somam-se a esse temor de ataques, que foram objeto de ameaças explícitas por Israel em mais de uma ocasião, os efeitos negativos da aplicação de severas sanções e embargos contra o país, cujo resultado, conforme observado na experiência norte-coreana, acaba contrariando os objetivos de sua imposição. Não é de espantar que o Irã apenas permaneça convicto da necessidade de adquirir armas nucleares que o capacitem mais assertivamente no plano da dissuasão internacional.

Esse reflexo já é perceptível, conforme se arrastam há anos rodadas de negociações até o momento infrutíferas no que concerne às suspeitas da natureza do programa nuclear

60 LOUKA, Ellie. Nuclear Weapons, Justice and the Law. Cheltenham: Edward Elgar, 2011, p. 383-389.

61 Ibidem, p. 399.

62 LOPEZ, George A.; CORTIRIGHT, David. United Nations Sanctions and Nuclear Weapons. In: BOULDEN, James; THAKUR, Ramesh Chandra; WEISS, Thomas George (Coords.). The United Nations and Nuclear Orders.Tokyo: United Nations University, 2009, p. 123. Ver ainda: JOHNSTONE, Ian. The Use of Force. In: BOULDEN, James; THAKUR, Ramesh Chandra; WEISS, Thomas George (Coords.) The United Nations and Nuclear Orders. . Tokyo: United Nations University, 2009, p. 132. 
iraniano. Na Conferência de Revisão do TNP realizada em 2010, Mahmoud Ahmadinejad, então presidente do Irã, formulou discurso cujas críticas são difíceis de serem refutadas pelos Estados Unidos e pelos organismos centrais responsáveis pela gestão e execução do regime internacional de não proliferação, e cujas proposições devem ser consideradas muito seriamente como um meio de se fortalecer, significativamente, o regime de não proliferação e a luta pelo desarmamento ${ }^{63}$ :

A bomba nuclear é um fogo contra a humanidade muito maior do que qualquer arma utilizada para defesa. A posse de bombas nucleares não deve ser fonte de orgulho; deve ser muito mais fonte de vergonha e desgosto. Ainda mais embaraçosa é a ameaça de uso desse tipo de arma, que não se compara a nenhum crime cometido ao longo da História. [...]

Valendo-se de privilégios especiais perante os principais organismos globais de segurança internacional e a AIEA, alguns Estados nucleares exploram amplamente essas armas contra Estados não nuclearmente armados, contrariando o espírito do TNP. Essa prática injusta, repetida sucessivamente, tornou-se um padrão. [...]

O governo dos Estados Unidos, que é o principal suspeito de produção, armazenagem e uso e ameaça de uso de armas nucleares, insiste em assumir um papel de liderança na revisão do TNP. A administração norteamericana, na sua recentemente anunciada Revisão da Postura Nuclear, anunciou que não irá produzir novas armas nucleares nem irá atacar com armas atômicas Estados não nuclearmente armados. [...]

Os EUA têm destacado a questão do terrorismo nuclear como parte de seus esforços para manter e aprimorar seus arsenais nucleares, desviando a opinião pública mundial da questão do desarmamento, enquanto se esquecem de que capacitar terroristas com armas nucleares apenas é possível para os Estados que possuem esse tipo de armamento, que já o utilizaram e que possuem um longo histórico de apoiar grupos terroristas quando isso convém aos seus interesses. [...]

O TNP deveria evoluir para um Tratado de Desarmamento e Não Proliferação (DNPT) e o desarmamento nuclear deveria ser inserido no núcleo de suas obrigações como algo transparente, vinculante, obrigatório e com mecanismos efetivos para imposição baseados em garantias internacionais. [...].

A introdução de garantias de segurança abrangentes e legalmente vinculantes sem caráter discriminatório é uma precondição para que se obtenha um desarmamento nuclear completo por parte dos Estados nuclearmente armados. [...]

${ }^{63}$ UNITED NATIONS. Statement by His Excellency Dr. Mahmoud Ahmadinejad President of the Islamic Republic of Iran before the 2010 Review Conference of the Parties to the Treaty on the Non-Proliferation of Nuclear weapons (NPT) United Nations, New York, 3 May 2010. Disponível em: <http://www.un.org/en/conf/npt/2010/statements/pdf/iran_en.pdf>. Acesso em: 19 nov. 2014. 
Deve inclusive haver a suspensão da participação no Conselho de Governos da AIEA pelos Estados que usem ou ameacem o uso de armas nucleares. [...]

Deve ainda ser considerado que a ameaça de uso de armas nucleares contra qualquer instalação nuclear pacífica representa uma violação da paz e segurança internacional, impondo uma rápida reação das Nações Unidas e a cessação de qualquer cooperação dos demais Estados membros do TNP com o Estado agressor.

Como antecipado, essa fala, além de apontar a raiz das principais críticas que se podem fazer contra o regime de não proliferação, contém propostas muito pertinentes para a consecução dos objetivos que, ao menos no discurso de todos os Estados membros do TNP, são comuns a todos eles. O fortalecimento das normas existentes e a criação de um tratado que inclua previsões como as apontadas no discurso de Ahmadinejad robusteceriam significativamente o ideal do desarmamento. A recusa desse tipo de proposição apenas legitima a recusa do regime iraniano de se submeter ao regime vigente.

É a pintura do quadro clássico do embate entre o direito e o poder, especialmente acirrado no nível internacional. A resultante desse embate, historicamente, tem revelado a fragilidade das normas internacionais para propiciar um progresso qualitativo quando interesses de nações poderosas se colocam como obstáculos. Esse viés pessimista é bem resumido por Koskenniemi:

\begin{abstract}
A fé no progresso internacionalista pode ter se tornado impossível de ser articulada de um modo intelectualmente respeitável. Poder e direito sempre se relacionaram de uma maneira mais complexa do que se verifica no imaginário convencional: se a segurança coletiva na Liga das Nações falhou devido à falta de apoio político, o sistema das Nações Unidas aparentemente padece justamente da circunstância de ser indistinguível do poder político. ${ }^{64}$.
\end{abstract}

É natural que a análise do comportamento internacional em relação ao desarmamento e à não proliferação nuclear propiciasse a constatação de obstáculos de natureza política

64 KOSKENNIEMI, Marti. The Gentle Civilizer of Nations - the Rise and Fall of International Law. Cambridge: Cambridge University, 2001, p. 514. 
que tendem a esvaziar a utilidade de todo o arcabouço de normas, instituições e decisões de organismos como o Conselho de Segurança elaborado para se lidar com a questão nuclear.

Quando se analisaram cada uma dessas normas e demais iniciativas relacionadas ao tema ao longo desta dissertação, esse viés negativo foi lembrado, em diversos momentos. Não se poderia avaliar adequadamente e de modo útil a questão, caso a análise desse arcabouço ocorresse em abstração das características que marcam a vida social dos $\operatorname{Estados}^{65}$.

Entretanto, como já foi exposto principalmente na primeira parte deste trabalho, a constatação dessas dificuldades de natureza política não pode invalidar o reconhecimento de que o ideal de desarmamento nuclear remanesce como algo necessário de ser defendido e buscado, nos moldes da proposição kantiana que enxerga na história as experiências negativas como representação do que não deve ser feito, e as quais não afastam a necessidade de se manterem, como uma baliza referencial, valores mais elevados que, mesmo impraticáveis no momento, propiciem amadurecimento qualitativo gradual.

Nesse sentido, mesmo as normas e organizações que são imperfeitas possibilitaram um sensível avanço na questão nuclear, como se verifica no próprio TNP, aquele que é tão criticado por seu caráter discriminatório, cujo mecanismo de revisões periódicas se revelou um dos principais instrumentos de elaboração do regime de não proliferação e do fomento de proposições muito relevantes para se propiciarem as bases de um mundo futuramente livre da ameaça nuclear.

Ainda que se aceitem as críticas, elas devem ser tomadas como algo a ser superado, não como um meio de deslegitimar tudo o que já foi realizado nessa busca. Como defendia Rousseau, "se a despeito de tudo isso o projeto não for executado, não o será por utópico, mas pela loucura dos homens; porque ser razoável em mundo marcado pela insanidade é em si mesmo uma forma de loucura"66.

65 KOSKENNIEMI, Marti. From Apology to Utopia. Cambridge: Cambridge University, 2005, p. 1-4.

66 ROUSSEAU, Jean-Jacques. Extrato e julgamento do projeto de Paz Perpétua. In: . Rousseau e as relações internacionais. Tradução de Sérgio Bath. São Paulo: Imprensa Oficial do Estado, 2003, p. 100. 


\section{CONCLUSÃO}

Ao longo do presente trabalho foi possível constatar que é altamente problemática a prática internacional de fundamentar as estratégias de segurança em torno das armas atômicas, atribuindo-lhes papel central na definição das políticas de defesa.

Apesar da sensação de segurança propiciada àqueles que possuem tais armamentos de poder destrutivo inigualável, paradoxalmente eles constituem fator de desestabilização e insegurança, à medida que outros Estados identifiquem neles o mesmo papel, e busquem seu desenvolvimento.

Essa dinâmica foi verificada durante a chamada primeira era nuclear, com a imediata corrida armamentista deflagrada a partir dos ataques contra Hiroshima e Nagasaki, que não pôde ser contida pelas propostas de controle internacional desenvolvidas pelos EUA e pela URSS. Essas nações buscavam atender aos seus próprios interesses, sem efetivamente propor bases sólidas para a concretização daquelas propostas, como foi observado na contextualização histórica exposta no capítulo 1 da segunda parte da dissertação.

A corrida armamentista desenvolveu-se de modo irrefreável até meados dos anos 1960, quando as principais potências identificaram que já possuíam arsenal suficientemente amplo para que pudessem se dedicar de modo mais incisivo às iniciativas em torno do interesse na contenção do espraiamento das armas nucleares, especialmente ao verificarem o crescente número de países que conseguiam desenvolver capacidade atômica militar. Essas iniciativas culminaram na celebração do Tratado de Não Proliferação Nuclear.

O TNP, assim, mesmo constituindo-se na primeira conquista em termos internacionais por um controle das armas nucleares, sofre muitas críticas por ter sido a representação legal do contexto político da época, especialmente por ter absorvido o desequilíbrio internacional marcado pela contraposição entre as potências nucleares e os demais Estados, o viés discriminatório do tratado.

Nesse sentido, o TNP pode ser considerado um exemplo perfeito do quanto descrito por Cassese sobre a conformação do Direito Internacional ser marcada pelo favorecimento 
dos Estados "mais poderosos", com o jurista italiano afirmando que, "de fato, ele é modelado de maneira a codificar e legitimar os interesses desses Estados" 1 .

Nesse mesmo período foi consolidada a política da dissuasão nuclear, a qual se baseava na ameaça de destruição recíproca pela perspectiva de que qualquer ataque com esse tipo de armamento seria respondido da mesma forma. No cenário, então, de uma "guerra sem vencedores", a avaliação dos comportamentos adotados pelos rivais impedia o acirramento de conflitos, perenizando uma estabilidade calcada no risco da destruição mútua.

A repetição dessa prática acabou tornando-a um elemento dado como perene da política internacional, havendo inclusive aqueles que a defendem como uma quase instituição, conforme observado na segunda parte desta dissertação. Entretanto, foi possível constatar que essa avaliação é falha, e apenas descreve uma faceta das relações internacionais, mas não a avalia criticamente.

De início, para uma avaliação sob o prisma jurídico que tenta se colocar num plano prescritivo e não meramente notarial da conduta dos Estados, deve-se questionar a compatibilidade das armas nucleares com o Direito, já que, por sua natureza, elas se constituem na própria negação do Direito e da Humanidade ${ }^{2}$.

Além disso, como foi possível concluir da análise crítica da política baseada na dissuasão nuclear, ela é instável, "altamente subjetiva, extremamente condicional, um artefato da primeira era nuclear que coincidia com a Guerra Fria" ${ }^{3}$. Esse subjetivismo pôde ser deduzido das recorrentes percepções das imperfeições e precariedades nos levantamentos efetuados pelos serviços de inteligência sobre as efetivas intenções dos adversários, como ficou evidente no episódio da Crise dos Mísseis.

Complicando ainda mais o funcionamento da política baseada na dissuasão nuclear, devem ser acrescidas as lembranças das imperfeições dos sistemas de informação e cadeias de alerta para a tomada de decisões sobre como responder a possíveis ataques em curso, assim como dos mecanismos automatizados de identificação de agressões em andamento, sujeitos a falhas técnicas de operação e interpretação. Uma decisão que seja, tomada a

CASSESE, Antonio. International Law in a Divided World. Oxford: Oxford University, 1986, p. 25.

Ibidem. p. 263.

CIMBALA, Stephen J. Nuclear Weapons and Cooperative Security in the 21st Century - the New Disorder. New York: Routledge, 2010, p. 8. 
partir de um erro pequeno nessa cadeia de alertas e sistemas de segurança, seria o estopim para escaladas de consequências globais devastadoras.

Se essas fragilidades eram verificadas quando a dissuasão era praticada apenas entre EUA e URSS, depois do fim da Guerra Fria, com a perspectiva de uma ampliação na proliferação nuclear caso mantidas as atuais políticas assentadas na manutenção dos arsenais atômicos ${ }^{4}$ (parte I, capítulo 2), esse cenário torna-se ainda mais preocupante, já que o subjetivismo é um fator a ser considerado para o funcionamento da dissuasão entre um número muito mais amplo de países, a grande maioria sem qualquer experiência com ela.

Os riscos impostos por uma realidade com vários atores nucleares são facilmente identificados por um exame das consequências de um mundo em que qualquer Estado, mesmo aqueles institucionalmente instáveis, fosse equipado com armas nucleares. Um mundo com essa realidade fatalmente seria menos seguro, em termos de possíveis acidentes ou detonações arbitrárias e injustificadas, consequentes de um verdadeiro pesadelo logístico imposto sobre os Estados despreparados para geri-lo, que terão de lidar com os difíceis desafios para a manutenção segura das armas em sua posse e seus vetores, assim como os temas de segurança e proteção associados ${ }^{5}$.

Depreende-se, dessa breve descrição, que a dissuasão, caso mantida a existência de armas nucleares e sua consequente proliferação generalizada que se acredita inevitável em médio prazo, terá difíceis, se não impossíveis, chances de operar exitosamente como ocorreu até hoje. Ao lado dessa realidade, ficou evidente também que as doutrinas desenvolvidas ao longo da Guerra Fria são ineficazes contra novas ameaças impostas pelas redes terroristas que não possuem nações nem cidadãos para defenderem, ou mesmo pelos ditadores que possuem meios de efetuarem ataques com armas de destruição em massa, ou secretamente dispô-las a aliados terroristas ${ }^{6}$.

Essas percepções decantadas ao longo do trabalho, especialmente em sua primeira parte, impõem a necessidade de se tentar alterar as bases em que se assenta a convivência

4 Havendo, como observado naquele capítulo, análises que apontam certeza matemática para a ocorrência de uma catástrofe nuclear nesse novo contexto.

5 LOUKA, Ellie. Nuclear Weapons, Justice and the Law. Cheltenham: Edward Elgar, 2011, p. 205-206.

6 JOHNSTONE, Ian. The Use of Force. In: BOULDEN, James; THAKUR, Ramesh Chandra; WEISS, Thomas George (Coords.). The United Nations and Nuclear Orders. Tokyo: United Nations University, 2009, p. 133. 
internacional, especialmente no que toca às políticas de segurança nacionais. Segundo o auspicioso estudo desenvolvido pela Academia Nacional de Ciências norte-americana, desenvolvido no ano da derrocada da URSS,

à medida que a confrontação bipolar fenece, o relativo significado dos perigos associados à proliferação nuclear deve aumentar. $\mathrm{O}$ novo ambiente deveria induzir a comunidade internacional a adotar medidas mais profundas de cooperação para preveni-la e reduzir suas consequências. [...] Com a tecnologia sendo mais amplamente conhecida e associada a componentes não nucleares que se encontram facilmente à disposição no comércio internacional, a chave é reduzir os aparentes incentivos de segurança que motivam Estados não nucleares a buscarem as armas atômicas ${ }^{7}$.

Por esse motivo é que há um reconhecimento doutrinário marcante no sentido de que "ao invés do controle da proliferação das armas atômicas, o melhor seria a proscrição desse tipo de arma, o que dissiparia qualquer dúvida quanto à possibilidade de eclosão de um não-desejado conflito nuclear" ${ }^{8}$.

É certo que se trata de objetivo que impõe uma mudança radical nos paradigmas em que se fundamenta a realidade internacional, especialmente porque, como já observado, um dos principais elementos que obstaculizam o banimento completo das armas nucleares, passo necessário para que seja possível ocorrer essa "indução para demover novos proliferadores", é justamente o comportamento dos Estados nuclearmente armados.

Nesse sentido, quando geralmente se pensa em desarmamento nuclear e seus desafios, logo acorrem ao pensamento máximas midiáticas como a ameaça do terrorismo nuclear, a inaceitável condição atômica norte-coreana, a percepção da incapacidade do regime estabelecido no tripé TNP-AIEA-Conselho de Segurança de fazer frente à Índia, Paquistão e Israel, a cada vez mais concreta possibilidade de um Irã nuclearmente armado, com potencial efeito catalisador de novos Estados nucleares no Oriente Médio e no mundo árabe etc.

7 Committee on International /Security and Arms Control - National Academy of Sciences. The future of the U.S. - Soviet nuclear relationship. Washington: National Academy, 1991, p. 21-22.

8 MAGALHÃES JÚNIOR, Japy Montenegro; MARQUES, Fernando Mário Rodrigues. A proliferação nuclear. Revista de Administração Pública, Rio de Janeiro, v. 12, n. 4, p. 173-197, out./dez.1978. Disponível em: <www.spell.org.br/documentos/download/15540>. Acesso em: 15 nov. 2014, p. 174. 
Indubitavelmente, todas essas circunstâncias compõem um plexo preocupante de novas ameaças, mas é necessário compreender que todas elas situam-se muito mais no plano das consequências, do que das causas que complicam se pensar num desarmamento nuclear concreto.

Foi possível identificar ao longo deste trabalho que esses novos riscos de proliferação decorrem justamente da crescente condenação internacional do comportamento dos Estados nuclearmente armados, que insistem em se manter como tais mesmo tendo assumido obrigação expressa de se desarmarem há quase cinquenta anos, por ocasião da assinatura do TNP, em 1968, e nunca deram passos concretos nessa direção.

O contumaz descumprimento da obrigação prevista no art. VI do tratado, o qual intencionalmente foi redigido sem cronogramas e mecanismos específicos para seu cumprimento certamente para propiciar esse comportamento vago, é motivo de críticas e condenações cada vez mais contundentes que, em última análise, não têm como ser refutadas, especialmente porque essa conduta perpetua o caráter discriminatório do tratado, o qual apenas fora aceito pelos demais Estados num caráter provisório.

É emblemático perceber que quando essas críticas partem de pivôs de alguns dos considerados maiores riscos contra o regime de não proliferação, elas apenas se tornam ainda mais concretas e legítimas, como na carta de Abdul Qadeer Khan enviada à Der Spiegel (primeira parte, capítulo 2), ou no pronunciamento de Ahmadinejad por ocasião da Conferência de Revisão do TNP, de 2010 (quarta parte, capítulo único) - o "telhado de vidro" dos Estados nuclearmente armados, nessas ocasiões, fica muito mais evidente.

Além de na recusa de obedecerem à obrigação central de se desarmarem, inserida no TNP, o comportamento dos Estados nuclearmente armados como principal obstáculo para refrear a proliferação e propiciar uma luta mais robusta pela obtenção da meta do desarmamento nuclear ficou evidente em diversos outros pontos tratados ao longo do trabalho.

De modo correlato, é muito negativa a vagueza desses Estados no que diz respeito a compromissos assumidos em contrapartida a reformas e adequações do TNP, como por ocasião de sua extensão por prazo indefinido apenas depois de sinalizarem positivamente para as exigências dos demais Estados, com a celebração do Tratado de Proibição completa de Testes Nucleares (CTBT) e o Tratado de Proibição de Materiais Físseis (FCMT). O 
projeto desses dois tratados apenas tomou força depois de 1995, por meio da barganha resumida nesse parágrafo. Como resultado, o TNP teve sua extensão indefinida aprovada, mas, passados quase vinte anos, nenhum dos dois tratados CTBT e FCMT está em vigor ${ }^{9}$, em grande parte devido à relutância dos Estados nucleares em apoiá-los de modo efetivo.

Ao mesmo tempo, suas ressalvas e mesmo recusas em assinarem protocolos anexos aos diversos tratados que instituem zonas livres de armas nucleares apenas impedem o pleno cumprimento desses tratados, dificultando a concretização de objetivos relacionados à não proliferação.

Essas constatações, todas elas graves, assumem contornos mais preocupantes quando se relembra a prática desses Estados nucleares não apenas com relação aos compromissos jurídicos que assumiram, mas no que toca ao seu comportamento na área política das relações internacionais.

Vale destacar, mesmo que brevemente, a absoluta falta de confiança que resultade seu discurso para que outros Estados se desarmem, ou não busquem armas nucleares, quando se relembram os episódios iraquiano ${ }^{10}$, ucraniano e líbio, países que, depois de serem desarmados, ficaram à mercê do jogo político dos principais Estados, e sofreram duras consequências por isso, com intervenções externas, perda de território e subjugação contundente imposta pelos Estados nucleares (segunda parte, capítulo 2).

Além disso, suas insistências no reforço da atuação político-institucional da AIEA e do Conselho de Segurança tornam-se insustentáveis à medida que os Estados nucleares, pela perenização do viés discriminatório do regime de não proliferação, situam-se fora do escopo de atuação desses dois órgãos. Assim, justifica-se a recusa de diversos Estados em aderirem, por exemplo, ao Protocolo Adicional dos acordos de salvaguarda de 1997, modelado pela AIEA, como meio de fortalecimento do sistema de inspeções, cujo robustecimento tornou-se necessário a partir da experiência iraquiana.

9 BLIX, Hans. Questões sobre a Guerra do Iraque: o uso de força, armas de destruição em massa e as Nações Unidas. In: DUPAS, Gilberto; LAFER, Celso; SILVA, Carlos Eduardo Lins da (Orgs.). A nova configuração mundial do poder. São Paulo: Paz e Terra, 2008, p. 340.

10 O caso do Iraque assume contornos ainda mais preocupantes porque o ataque que sofreu em 2003 ocorreu mesmo depois de não ter sido aprovada pelo Conselho de Segurança a proposta de Resolução que autorizaria uma intervenção no país. A não aprovação de uma ação, necessariamente, deve ser interpretada como uma decisão contra essa ação. Cf. FRANCK, Thomas M. Fairness in International Law and Institutions. New York: Oxford University, 1995, p. 273. 
Há ainda que se recapitular que esses mesmos Estados nuclearmente armados, que relutam em aderir aos mecanismos desenvolvidos multilateralmente, são os principais responsáveis por iniciativas voluntárias que desagregam os esforços de cooperação e retiram a crença no funcionamento desses mecanismos negociados. A aprovação de resoluções do Conselho de Segurança que tornam vinculantes obrigações de tratados, como a Convenção contra atos de terrorismo internacional, mesmo para Estados que não aderiram a esses tratados, é um exemplo claro, especialmente pelo controle das nações nucleares sobre o mecanismo de aprovação de resoluções por aquele órgão.

Outra ilustração dessa faceta danosa ao regime de não proliferação é o crescente apoio a ataques preventivos contra pretensos proliferadores, numa interpretação elástica e ilegal do direito à autodefesa estabelecido na Carta da ONU. Esses ataques, à medida que se tornem mais frequentes, apenas reforçarão a sensação de medo e de necessidade de incrementos bélicos por parte dos Estados classificados como párias internacionalmente.

Paradoxalmente, há ainda que se destacar que, enquanto insistem em adotar esses comportamentos totalmente contrários aos objetivos da não proliferação e do desarmamento nuclear, esses Estados destacam-se por adotar iniciativas para-institucionais de questionável legalidade, como a Proliferation Security Initiative, medida que já conta com sensível número de adesões e que, ao fim e ao cabo, apenas representa o exercício da musculatura americana em águas internacionais interceptando navios e embarcações para impor um controle e uma fiscalização contra o tráfico de armas e equipamentos para programas nucleares.

Ainda com relação a essa postura pouco inspiradora dos Estados nucleares, há que se destacar uma recorrente insatisfação dos demais países, que enxergam em diversas das condenações e dos discursos contra a possibilidade de desenvolverem programas nucleares manifestamente pacíficos apenas o interesse financeiro das principais potências em manterem um mercado cativo de equipamentos e combustíveis nucleares.

A insatisfação gerada por esse tipo de discurso apenas acirra ainda mais a resistência de países que, mesmo pacíficos, não aceitam subjugar-se aos regimes criados, ou às iniciativas de reforçá-los.

É digno de nota o exemplo brasileiro na questão, país que nunca teve uma pretensão nuclear bélica concreta e ameaçadora, que (i) é um dos membros fundadores da AIEA, (ii) 
membro do Tratado de Tlatelolco, (iii) celebrou acordo bilateral de controle nuclear com seu rival regional e (iv) possui previsão constitucional sobre uso exclusivamente pacífico da energia nuclear (art. 21, XXIII, 'a').

A despeito dessas características, o desenvolvimento de seu programa nuclear civil ${ }^{11}$ foi marcado pela recusa nacional em se submeter a um regime considerado desequilibrado e discriminatório, o que o levou a negar a assinatura do TNP até o fim da década de 1990. Nesse contexto, preferiu estabelecer um relacionamento de cooperação com a Alemanha, por meio de acordo que além da compra de reatores nucleares, previa também a transferência de tecnologia, um interesse estratégico do país para não se tornar mais um comprador eterno de produtos e combustível nuclear dos EUA.

Essa decisão foi duramente questionada pelos Estados Unidos devido aos seus interesses financeiros, mas sob a alegação do risco de proliferação de armas nucleares ${ }^{12}$, assim como em razão de uma visão paternalista acerca do Terceiro Mundo, cujos países, para muitos senadores e deputados em Washington, não teriam maturidade suficiente para implementar um projeto daquela natureza ${ }^{13}$.

Mesmo em se tratando de um país pacífico, que não tem pretensões de proliferação nuclear bélica, considerado parceiro das principais potências nucleares, diferentemente do Irã, da Coreia do Norte ou do Paquistão, o país viu-se sob críticas similares às feitas contra aqueles países, motivando necessária reação contundente, com a eloquência de Soares:

Se, à vista de todos os tratados que o Brasil assinou, se, ademais, à vista do sistema de salvaguardas da AIEA que o País contribuiu para tornar realidade, seja como membro fundador da Agência seja por ter incorporado tais regras nas suas relações bilaterais com os EUA e Alemanha Federal, ainda a se pretender que o Brasil venha a ser o perturbador da paz, porque busca fontes de energia de fissão nuclear, fabricando o ciclo completo do combustível, sem depender de uma

11 Para uma compreensão de como se deu o desenvolvimento nuclear brasileiro: BARBOSA, José Alberto Maia. Direito nuclear - tecnologia nuclear: uma Estratégia Nacional de Defesa. Campinas: Millenium, 2011, p. 7-9. Ver ainda: COIMBRA, Guilhermina L. A história e o desenvolvimento da energia nuclear no Brasil. In: GOMES, Fabio Luiz (Coord.). Direito internacional - perspectivas contemporâneas. São Paulo: Saraiva, 2010; GOLDEMBERG, José. Um programa nuclear alternativo. In: SIMON, David N. Energia nuclear em questão. 2. ed. Rio de Janeiro: Instituto Euvaldo Lodi, 1981; FERREIRA JÚNIOR, Geraldo Miniuci. O acordo nuclear Brasil-Alemanha. In: DANESE, Sergio França (Org.). Ensaios de História diplomática do Brasil. Brasília: Fundação Alexandre de Gusmão, 1989. (Cadernos do IPRI, n. 2)

12 GOLDEMBERG, José. Um programa nuclear alternativo. In: SIMON, David N. Energia nuclear em questão. 2. ed. Rio de Janeiro: Instituto Euvaldo Lodi, 1981, p. 20.

13 FERREIRA JÚNIOR, op. cit. p. 161. 
indústria mundial monopolística de urânio enriquecido, é, no mínimo, mostrar má-fé ou, o que é pior, grosseira ignorância dos fatos. ${ }^{14}$

Não seria de espantar, portanto, a aversão do país contra novas iniciativas adotadas ou planejadas pelos Estados nuclearmente armados, como se verifica pela recusa na adoção do Protocolo Adicional da AIEA de $1997^{15}$, não porque pretenda romper com o regime de não proliferação, mas porque o Brasil se nega a apoiar a manutenção de uma realidade desequilibrada e inaceitável.

Vistos em conjunto os exemplos dos comportamentos contraditórios e inconsistentes dos Estados nuclearmente armados, esses aspectos inspiram pouca confiança nos demais Estados, que não veem motivos para aderir a novos tratados e convenções de não proliferação e desarmamento, reação mais do que justificada e compreensível. É importante essa constatação, porque permite encarar de modo correto o problema do desarmamento, não mais punindo, mesmo que em discurso, os Estados que apenas estão, a bem da verdade, reagindo a essa prática internacional lamentável das nações nuclearmente armadas.

Ao se identificar com mais objetividade o principal foco de problemas e dificuldades para o desarmamento nuclear, ainda que remanesçam as dificuldades para sua consecução, podem-se abordá-las de maneira mais consciente e, portanto, com maiores chances de êxito do que se forem atacados os sintomas, e não as causas.

Constatando-se que a raiz do problema situa-se no comportamento dos Estados que, bem ou mal, compõem o centro das tomadas de decisão das principais iniciativas na questão da segurança internacional, facilmente se percebe a enormidade do obstáculo que se busca enfrentar, tornando-se ainda mais evidente o idealismo que marca a questão.

Com efeito, trata-se de Estados com capacidade inquestionável de resistirem às tentativas de imposição de tratados e normas ${ }^{16}$, e que não enxergam motivos para

14 SOARES, Guido Fernando Silva. As salvaguardas nos acordos nucleares. São Paulo: Bushatsky, 1977, p. $157-158$.

15 IAEA. Additional Protocols. Disponível em: <http://www.iaea.org/safeguards/documents/AP_status_list.pdf>. Acesso em: 9 dez. 2014.

16 MORE, Rodrigo Fernandes. O desarmamento no sistema de segurança coletiva da ONU. 2005. Tese (Doutorado) - Faculdade de Direito, Universidade de São Paulo, São Paulo, 2002, p. 324. 
mudarem o comportamento desenvolvido de acordo com o que acreditam ser suas prioridades, mesmo inconfessáveis ${ }^{17}$.

A dificuldade da questão emerge da análise de Koskenniemi sobre os entraves para o desenvolvimento do Direito Internacional:

O internacionalismo legal sempre flutuou perigosamente entre o humanismo cosmopolita e a apologia imperialista, revelando-se como um dos dois no momento em que era identificado como necessário para apoiar um arranjo normativo ou institucional em particular. Nas condições postas durante a Guerra Fria, pode ter sido possível pensar que isso resultava de interpretações políticas dos protagonistas na luta que se projetava sobre o Direito. Atualmente, tornou-se muito mais difícil acreditar que existe uma racionalidade arraigada no direito internacional que seja independente das perspectivas políticas de como ele é visto ${ }^{18}$.

De fato, não se pode ignorar o peso dessa visão, que destaca com realismo um dado concreto do contexto verificado atualmente. Contudo, e aí se coloca de modo determinante a utilidade do projeto kantiano na questão, diante de uma realidade marcadamente imperfeita, cujas bases não propiciam uma convivência harmoniosa e, pior, como foi possível observar, apontam para o incremento inaceitável da ocorrência do desastre nuclear global, não se deve sucumbir às experiências negativas apresentadas pela História.

Verifica-se, então, com ainda mais força, a utilidade de se valer do projeto kantiano À Paz Perpétua com o intuito de extrair dele o exemplo necessário para fomentar a continuidade da luta pela obtenção da meta do desarmamento nuclear, ainda que a ideia da preponderância da justiça entre os Estados, interligada com a noção de justiça mundial ou cosmopolita, "por ora só exista como um mito" 19.

17 Apesar da retórica do terrorismo como ameaça que justifique a manutenção dos arsenais atômicos, especula-se que o lobby industrial bélico americano constitua um dos principais motivos para a insistência nessa política. Segundo BANDEIRA, Luiz Alberto Moniz. A segunda guerra fria. Rio de Janeiro: Civilização Brasileira, 2013, p. 162: “Em 1986, as corporações empreiteiras do Pentágono na Califórnia receberam 20\% do orçamento de Departamento de Defesa, enquanto Nova York, Texas e Massachusetts apropriaram-se de $21 \%$. Os imensos custos dos Estados Unidos com a produção de armamentos não decorrem tanto de fatores de segurança quanto de incoercíveis necessidades econômicas".

18 KOSKENNIEMI, Marti. The Gentle Civilizer of Nations - the Rise and Fall of International Law. Cambridge: Cambridge University, 2001, p. 513.

19 BULL, Hedley. A sociedade anárquica. Tradução de Sérgio Bath. São Paulo: UnB, 2002, p. 100. 
Justamente com o comportamento pautado coerentemente nesse mito, ainda que por meio de pequenos avanços, modestas conquistas, não por uma pretensa e impossível imposição artificial de uma realidade utópica, é que se torna mais plausível enfrentar o desafio de superar uma realidade imperfeita. Abranches, nesse sentido, reconhecia que a "abolição da guerra era inconcebível sem rígido controle multilateral ou constituição de uma força de polícia supranacional”. Mesmo confessando que era uma meta extremamente remota, ele afirmava que as dificuldades "não dispensam o cientista do direito de enfrentar pelo menos as questões básicas dela oriundas no complexo quadro das repercussões que os usos bélicos da energia nuclear tiveram sobre o Direito das Gentes." ${ }^{20}$

Ou, como estabelece Bobbio,

enquanto um ideal moral, para nós não deve importar se ele poderá ser realizado e quando será realizado. Nós queremos tender para ele porque, sendo um ideal moral, o agir em conformidade constitui um dever nosso, independentemente do fato de que os nossos esforços sejam premiados pelo sucesso ${ }^{21}$.

É exatamente nesse prisma, conforme exposto na primeira parte desta dissertação, que se poderia utilizar o projeto kantiano, um referencial moral que impõe padrões de comportamento a serem somados numa escala evolutiva, permitindo o rompimento de amarras realistas que tendem a impedir um avanço qualitativo na luta pelo desarmamento nuclear.

Não se trata de uma proposição desarrazoada, nem de se tentar inventar a roda. Já há manifestações recorrentes sobre a necessidade de se lutar pelo objetivo do completo banimento das armas nucleares por meio de objetivos muito mais modestos, mas que, em conjunto, propiciariam cada vez mais uma aproximação daquela meta ambiciosa.

Em interessante artigo de Ednan Agaev publicado sob os auspícios da UNIDIR (Instituto De Pesquisa Sobre Desarmamento Das Nações Unidas ${ }^{22}$ ), há uma descrição de

20 ABRANCHES, C. A. Dunshee de. Proscrição das armas nucleares. São Paulo: Freitas Bastos, 1964, p. $17-18$.

21 BOBBIO, Direito e Estado no Pensamento de Emanuel Kant. Tradução de Alfredo Fait. 3. ed. Brasília: Universidade de Brasília, 1995, p. 157-158.

22 UNIDIR. (United Nations Institute for Disarmament Research.) Disponível em: <http://www.unidir.org/>. Acesso em: 20 dez. 2014. 
passos necessários para o desarmamento que se alinham, de certo modo, ao quanto aqui exposto $^{23}$, prevendo-se um processo lento e gradual de redução do peso atribuído ao poder militar na definição das estratégias nacionais, acompanhado do fortalecimento gradativo de alternativas políticas e institucionais para a dissuasão como garantia de segurança, num processo longo e demorado para a consolidação de novo patamar qualitativo para as relações internacionais.

A adoção desses passos poderia ser catalisada por uma previsível e crescente pressão financeira mundial para a contenção de orçamentos públicos, impondo uma racionalização dos gastos que passaria especialmente pela reavaliação das estruturas de defesa, ainda mais se essa reavaliação constituir uma meta comum em escala internacional, a qual imporia o desenvolvimento de aparatos de verificação e monitoramento necessários para assegurar a confiança recíproca do desarmamento em todos os países.

Mais à frente, Agaev resume essas etapas para concluir que

o desarmamento constitui um processo passo-a-passo que se implementa por meio de uma série de estágios objetivos e consecutivos. Enquanto isso, em cada um desses estágios, medidas concretas, dependendo de seu conteúdo e do grau de aplicabilidade, devem ser implementadas simultaneamente em diferentes níveis multilateral, bilateral e unilateral - com uma escrupulosa atenção aos interesses de todos os participantes.

Reforçando esse aspecto de que o desarmamento, mesmo representando uma meta ambiciosa, deve ser buscado passo-a-passo, é relevante identificar, na declaração de abertura dos trabalhos do Comitê Preparatório para a Conferência de Revisão do TNP prevista para 2015, que enquanto o desarmamento nuclear completo tem sido considerado o objetivo principal dos Estados, os objetivos mais modestos para o desarmamento nuclear permanecem como prioridade urgente ${ }^{24}$.

23 AGAEV, Ednan. Approaches to Guaranteeing National and International Security at the Present Juncture and the Role of Disarmament. New York: UNIDIR, 1992, p. 15-17. Disponível em: <http://www.unidir.org/files/publications/pdfs/disarmament-and-limitation-of-armaments-en-425.pdf>.

Acesso em: 12 jun. 2013, tradução livre do original em inglês.

24 THIRD Session of The Preparatory Committee (PrepCom) for the 2015 Review Conference of the Parties to the Treaty on the Non-Proliferation of Nuclear Weapons (NPT). 28 April - 09 May 2014, New York. 
Não se trata, contudo, de um caminho fácil, no qual as "perspectivas são totalmente incertas, e a sombra remanesce presente; padrões mais elevados devem ser buscados; eles persistem primeiro para serem atingidos e depois implementados - se algum dia...". 25

Independente das dificuldades, esse caminho é válido mesmo pela tentativa, um meio de ao menos buscar o cumprimento do compromisso da humanidade com as vítimas de Hiroshima, conforme exposto no memorial da paz, e que constitui a epígrafe deste trabalho - “descansem em paz, porque não deveremos repetir o terror”.

Disponível em: http://www.un.org/disarmament/WMD/Nuclear/NPT2015/PrepCom2014/ Acesso em: 17 nov. 2014.

25 CASELlA, Paulo Borba. Pax Perpetua - a Review of the Concept from the Perspective of Economic Integration. In: CASELLA, Paulo Borba (Coord.). Dimensão internacional do Direito - Estudos em homenagem a G. E. do Nascimento e Silva. São Paulo: LTr, 2000, p. 88, tradução livre e simplificada do original em inglês: "Perspectives are not necessarily bleak; they are totally uncertain. The shadow remains present; higher standards may be looked for; they remain to be first achieved and then implemented - if ever..." 


\section{REFERÊNCIAS}

ABRANCHES, C. A. Dunshee de. Proscrição das armas nucleares. São Paulo: Freitas Bastos, 1964.

ACCIOLY, Hildebrando; NASCIMENTO E SILVA, Geraldo E. do; CASELLA, Paulo Borba. Manual de Direito Internacional Público. 16. ed. São Paulo: Saraiva, 2008.AFONSO DA SILVA, José. Curso de direito constitucional positivo. 20. ed. São Paulo: Malheiros, 2002.

AGAEV, Ednan. Approaches to Guaranteeing National and International Security at the Present Juncture and the Role of Disarmament. New York: UNIDIR, 1992, p. 15-17. Disponível em: <http://www.unidir.org/files/publications/pdfs/disarmam ent-andlimitation-of-armaments-en-425.pdf >. Acesso em: 12 jun. 2013

AHLSTRÖM, Christer. Proliferation Security Initiative: International Law Aspects of the Statement of Interdiction Principles. Disponível em: <http://www.sipri.org/yearbook/2005/pressrl/SIPRIYB2005PRfinal.pdf>, p. 23. Acesso em: 20 nov. 2014.

AKEHURST, Michael. Introdução ao Direito internacional. Tradução de F. Ruivo. Coimbra: Almedina, 1985.

ALVES PEREIRA, Antonio Celso. O recurso à força pelos estados e a legítima defesa no direito internacional contemporâneo. In: MENEZES DIREITO, Carlos Alberto; CANÇADO TRINDADE, Antonio Augusto; ALVES PEREIRA, Antonio Celso (Orgs.). Novas perspectivas do Direito internacional contemporâneo - Estudos em homenagem ao Professor Celso D. de Albuquerque Mello. São Paulo: Renovar, 2008.

AMARAL JUNIOR, Alberto do. $O$ direito de assistência humanitária. São Paulo: Renovar, 2003.

ANNAN, Koffi. Message at the Peace Memorial Ceremony. Hiroshima, 2004. Disponível em: 〈http://www.un.org/News/Press/docs/2004/sgsm9441.doc.htm>.

ARENDT, Hannah. Lições sobre a filosofia política de Kant. Tradução de André Duarte de Macedo. Rio de Janeiro: Relume-Dumará, 1993.

ASADA, Masahiko. The Challenge Inspection System of the CWC. In: THAKUR, Ramesh; HARU, Ere (Orgs.). The Chemical Weapons Convention. Tokyo: United Nations University, 2006, 
BANDEIRA, Luiz Alberto Moniz. A segunda guerra fria. Rio de Janeiro: Civilização Brasileira, 2013.

BARBAS HOMEM, Antonio Pedro. História das relações internacionais. Coimbra: Almedina, 2003.

BARBOSA, José Alberto Maia. Direito nuclear - tecnologia nuclear: uma Estratégia Nacional de Defesa. Campinas: Millenium, 2011.

BARBOSA, Rui. A Grande Guerra. Rio de Janeiro: Guanabara, 1932.

BERNARDO, João. A democracia totalitária. São Paulo: Cortez, 2004.

BIDART CAMPOS, German J. El aporte del derecho internacional de los derechos humanos al derecho constitucional argentino. In: Los derechos humanos del siglo XXI. Buenos Aires: Ediar, 2005.

BLIX, Hans. Questões sobre a Guerra do Iraque: o uso de força, armas de destruição em massa e as Nações Unidas. In: DUPAS, Gilberto; LAFER, Celso; SILVA, Carlos Eduardo Lins da (Orgs.). A nova configuração mundial do poder. São Paulo: Paz e Terra, 2008.

BOBBIO, Norberto. Direito e Estado no pensamento de Emmanuel Kant. Tradução de Alfredo Fait. 3. ed. Brasília: Editora UnB, 1995.

BOULDEN, James; THAKUR, Ramesh Chandra; WEISS, Thomas George. The United Nations and Nuclear Orders: Context, Foundations, Actors, Tools, and Future Prospects. In:___(Coords.). The United Nations and Nuclear Orders. Tokyio: United Nations University, 2009.

BROODY, Reed. As Nações Unidas: direitos humanos, paz e segurança. In: VILHENA VIEIRA, Oscar (Coord.). Direitos humanos - Estado de Direito e a construção da paz. São Paulo: Quartier Latin, 2005.

BULL, Hedley. A sociedade anárquica. Tradução de Sergio Bath. Brasília: UnB/IPRI, 2002 .

BUNDY, McGeorge; CROWE JR., William J.; DRELL, Sidney D. Reducing Nuclear Danger - The Road Away from the Brink. New York: Council on Foreign Relations Press, 1993.

BUZAN, Barry; HANSEN, Lene. A evolução dos estudos de segurança internacional. São Paulo: Unesp, 2012. 
BYERS, Michael. A lei da guerra - direito internacional e conflito armado. Rio de Janeiro: Record, 2007.

CACHAPUZ DE MEDEIROS, Antonio Paulo. O direito internacional e o terrorismo. In: MENEZES DIREITO, Carlos Alberto; CANÇADO TRINDADE, Antonio Augusto; ALVES PEREIRA, Antonio Celso (Orgs.). Novas perspectivas do Direito internacional contemporâneo - Estudos em homenagem ao Professor Celso D. de Albuquerque Mello. São Paulo: Renovar, 2008.

CANÇADO TRINDADE, Antonio Augusto. Princípios do Direito internacional. Brasília: Editora UnB, 1981.

CARVALHO RAMOS, André. Teoria geral dos direitos humanos na ordem internacional. 2. ed. São Paulo: Saraiva, 2012.

CASELlA, Paulo Borba. Direito Internacional, terrorismo e aviação civil. São Paulo: Quartier Latin, 2006.

Fundamentos do direito internacional pós-moderno. São Paulo: Quartier Latin, 2008.

Pax Perpetua - a Review of the Concept from the Perspective of Economic Integration. In: CASELLA, Paulo Borba (Coord.). Dimensão internacional do Direito Estudos em homenagem a G. E. do Nascimento e Silva. São Paulo: LTr, 2000.

União Europeia - instituições e ordenamento jurídico. São Paulo: Ltr, 2012.

CASSESE, Antonio. International Law in a Divided World. Oxford: Oxford University, 1986.

CHOUKR, Fauzi Hassan; AMBOS, Kai. Tribunal penal internacional. São Paulo: RT, 2000.

CÍCERO. Dos deveres. Tradução de A. Marins. São Paulo: Martin Claret, 2002.

CIMBALA, Stephen J. Nuclear Weapons and Cooperative Security in the $21^{\text {st }}$ Century the New Disorder. New York: Routledge, 2010.

COIMBRA, Guilhermina L. A história e o desenvolvimento da energia nuclear no Brasil. In: GOMES, Fabio Luiz (Coord.). Direito internacional - perspectivas contemporâneas. São Paulo: Saraiva, 2010. 
Committee on International /Security and Arms Control - National Academy of Sciences. The Future of the U.S. - Soviet Nuclear Relationship. Washington: National Academy, 1991.

COMTE-SPONVILlE, André. Pequeno tratado das grandes virtudes. Tradução de Eduardo Brandão. São Paulo: Martins Fontes, 1995.

DALLARI, Dalmo de Abreu. As Nações Unidas: Direitos humanos, paz e segurança. In: VIEIRA, Oscar Vilhena (Coord.). Direitos humanos - Estado de Direito e a construção da paz. São Paulo: Quartier Latin, 2005.

. Elementos de Teoria geral do Estado. 20. ed. São Paulo: Saraiva, 1998.

DALLARI, Pedro Bohomoletz de Abreu. A experiência constitucional brasileira na transição árabe. Política Externa (USP), v. 21, p. 91-94, 2012. Disponível em: <http://politicaexterna.com.br/660/experiencia-constitucional-brasileira-transicao-arabe/>. Acesso em: 30/11/2014.

DAMROSCH, Lori Fisler. Codification and Legal Issues. In: BOULDEN, James; THAKUR, Ramesh Chandra; WEISS, Thomas George (Coords.). The United Nations and Nuclear Orders. Tokyo: United Nations University, 2009.

DAVENPORT, Kelsey; KIMBALL, Daryl G. Nuclear-Weapon-Free Zones (NWFZ) at a Glance. Disponível em: 〈http://www.armscontrol.org/factsheets/nwfz〉. Acesso em: 18 nov. 2014.

DOLINGER, Jacob. Os Estados Unidos perante o direito internacional - A decadência jurídica de uma grande nação. In: MENEZES DIREITO, Carlos Alberto; CANÇADO TRINDADE, Antonio Augusto; ALVES PEREIRA, Antonio Celso (Orgs.). Novas perspectivas do Direito internacional contemporâneo - Estudos em homenagem ao Professor Celso D. de Albuquerque Mello. São Paulo: Renovar, 2008.

DUPAS, Gilberto; Lafer, Celso; SILVA, Carlos Eduardo Lins da. A nova configuração do poder mundial. São Paulo: Paz e Terra, 2008.

DUPUY, René-Jean. O Direito internacional. Tradução de Clotilde Cruz. Coimbra: Almedina, 1993.

EINSTEIN, Albert. Como vejo o mundo. Tradução de H.P. Andrade. Rio de Janeiro: Nova Fronteira, 2011.

EVANS, Gareth. A meia-noite do desarmamento. O Estado de S. Paulo, São Paulo, 3 mar. 2012 . 
FERREIRA JÚNIOR, Geraldo Miniuci. O acordo nuclear Brasil-Alemanha. In: DANESE, Sergio França (Org.). Ensaios de História diplomática do Brasil. Brasília: Fundação Alexandre de Gusmão, 1989. (Cadernos do IPRI, n. 2)

FINLAY, Brian; GROSSMAN-VERMAAS, Rita. Technology Proliferation, Globalization and the Role of the United Nations. In: BOULDEN, James; THAKUR, Ramesh Chandra; WEISS, Thomas George (Coords.). The United Nations and Nuclear Orders. Tokyo: United Nations University, 2009.

FISCHER, David. History of the International Atomic Energy Agency: the First Forty Years. Vienna: The Agency, 1997. Disponível em: <http://wwwpub.iaea.org/MTCD/publications/PDF/Pub1032_web.pdf>. Acesso em: 30 jun. 2013.

FONSECA Jr., Gelson. As múltiplas dimensões do pensamento de Rousseau. (Primeira parte do Prefácio). In: ROUSSEAU, Jean-Jacques. Rousseau e as relações internacionais. São Paulo: Imprensa Oficial do Estado, 2003.

FRANCK, Thomas M. Fairness in International Law and Institutions. New York: Oxford University, 1995.

FRIEDMAN, Thomas L. O presente eterno. O Estado de São Paulo, São Paulo, 4 dez. 2014, A19.

FURLAN, Fernando de Magalhães. Supranacionalidade nas associações de Estados repensando a soberania. Curitiba: Juruá, 2008.

GADDIS, John Lewis. The Unexpected John Foster Dulles: Nuclear Weapons, Communism and the Russians. In: IMMERMAN, Richard H. John Foster Dulles and the Diplomacy of the cold War. New Jersey: Princeton University, 1990.

GINGER, Ann Fagan. Nuclear Wepons are Illegal - The Historic Opinion of the World Court and How It Will Be Enforced. New York: The Apex, 1998.

GOLDEMBERG, José. Um programa nuclear alternativo. In: SIMON, David N. Energia nuclear em questão. 2. ed. Rio de Janeiro: Instituto Euvaldo Lodi, 1981.

GONÇALVES, Alcindo; FONTOURA COSTA, José Augusto. Governança global e regimes internacionais. São Paulo: Almedina, 2011.

HABERMAS, Jürgen. Kant's Idea of Perpetual Peace: At Two Hundred Years' Historical Remove. In: _. The Inclusion of the Other - Studies in Political Theory. Editado por C. Cronin. Cambridge: MIT Press, 1998. 
The European Nation-State. In: The Inclusion of the Other - Studies in Political Theory. Editado por C. Cronin. Massachussets: MIT Press, 1998.

HAMAI, Shinso. A-Bomb Mayor - Warnings and Hope from Hiroshima. Tradução de Elizabeth W. Baldwin. Hiroshima: Toppan, 2010.

HENCKAERTS, Jean-Marie; DOSWALD-BECK, Louise. Customary International Humanitarian Law. New York: Cambridge University Press / International Committee of The Red Cross, 2005.

HESSE, Herman. O jogo das contas de vidro. Tradução de L. A. Viotti e F. V. de Souza. 14. ed. São Paulo: Record, 2003.

HOBSBAWM, Eric. A ordem pública em uma era de violência. In: Globalização, democracia e terrorismo. Tradução de José Viegas. São Paulo: Companhia das Letras, 2007.

Era dos extremos. 2. ed. Tradução de Marcos Santarrita. São Paulo: Companhia das Letras, 1995.

HUNTINGTON, Samuel P. A superpotência solitária. In: DUPAS, Gilberto; LAFER, Celso; SILVA, Carlos Eduardo Lins da (Orgs.). A nova configuração mundial do poder. São Paulo: Paz e Terra, 2008.

IMMERMAN, R. H. John Foster Dulles and the Diplomacy of the Cold War. New Jersey: Princeton University, 1990.

JOHNSTONE, Ian. The Use of Force. In: BOULDEN, James; THAKUR, Ramesh Chandra; WEISS, Thomas George (Coords.). The United Nations and Nuclear Orders. Tokyo: United Nations University, 2009.

KANT, Immanuel. À paz perpétua. Tradução de Marco Antônio Zingano. São Paulo: L\&PM Editores, 1989.

KELSEN, Hans. Derecho y paz en las relaciones internacionales. Tradução de Florencio Acosta. 2. ed. Cidade do México: Fondo de Cultura Económica, 1986.

KOSKENNIEMI, Martti. From Apology to Utopia. Cambridge: Cambridge University, 2005 .

The Gentle Civilizer of Nations - the Rise and Fall of International Law. Cambridge: Cambridge University, 2001. 
KUZNICK, Peter J. A Tragic Life: Oppenheimer and the Bomb. Disponível em: https://www.armscontrol.org/print/1851. Acesso em: 21 Dez. 2014.

LAFER, Celso. A reconstrução dos direitos humanos - um diálogo com o pensamento de Hannah Arendt. São Paulo: Companhia das Letras, 1988.

Comércio, desarmamento e direitos humanos: reflexões sobre uma experiência diplomática. 2. ed. São Paulo: Paz e Terra, 2006.

Paradoxos e possibilidades. Rio de Janeiro: Nova Fronteira, 1982.

LAMAZIÈRE, Georges. Desarmamento nuclear e hegemonia - em busca de um novo paradigma. Revista Estudos Avançados, Instituto de Estudos Avançados da Universidade de São Paulo. Disponível em: <www.iea.usp.br/artigos>. Acesso em: 9 dez. 2014, p. 7.

LANGEWIESCHE, William. O bazar atômico - a escalada do poderio nuclear. Tradução de José Viegas. São Paulo: Companhia das Letras, 2007.

LODGAARD, Sverre. Proliferation: Relevant Factors. In: Curbing the Spread of Nuclear Weapons - an Informal Panel Discussion on the Occasion of the 20th Anniversary of the Vienna International Centre. Outubro 1999. Disponível em: 〈http://www.iaea.org/newscenter/focus/npt/curbing_spread_nuclear_weapons.pdf $>$.

Acesso em: 20 jun. 2013.

LOPEZ, George A.; CORTIRIGHT, David. United Nations Sanctions and Nuclear Weapons. In: BOULDEN, James; THAKUR, Ramesh Chandra; WEISS, Thomas George (Coords.). The United Nations and Nuclear Orders. Tokyo: United Nations University, 2009.

LOSANO, Mario G. Sistema e estrutura no Direito. Tradução de Carlos Alberto Dastoli. São Paulo: Martins Fontes, 2008.

LOUKA, Ellie. Nuclear Weapons, Justice and the Law. Cheltenham: Edward Elgar, 2011.

MAGALHÃES, José Carlos de. Uma introdução. In: MERCADANTE, Araminta de Azevedo; MAGALHÃES, José Carlos de (Coords.). Solução e prevenção de litígios internacionais. São Paulo: NECIN - Projeto CAPES, 1998.

MAGALHÃES JÚNIOR, Japy Montenegro; MARQUES, Fernando Mário Rodrigues. A proliferação nuclear. Revista de Administração Pública, Rio de Janeiro, v. 12, n. 4, p. 173197, out./dez.1978. Disponível em: 〈www.spell.org.br/documentos/download/15540>. Acesso em: 15 nov. 2014. 
MARCOVITCH, Jacques. Um brasileiro na História do Mundo. In: MARCOVITCH, J. (Org.). Sérgio Vieira de Mello - pensamento e obra. São Paulo: Edusp/Saraiva, 2004.

MARTINS, Luciano. A (des)ordem mundial. In: DUPAS, Gilberto; LAFER, Celso; SILVA, Carlos Eduardo Lins da (Orgs.). A nova configuração mundial do poder. São Paulo: Paz e Terra, 2008.

McNAMARA, Robert S. In Retrospect - The Tragedy and Lessons of Vietnam. New York: Times Books, 1995.

MCINNIS, Edgard. História da II Guerra Mundial - sexto e último ano de operações. Tradução de Homero de Castro Jobim. Porto Alegre: Globo, 1962.

MEIRA MATTOS, Adherbal. Direito internacional público. Rio de Janeiro: Renovar, 1996.

MELlO, Celso D. de Albuquerque. Curso de Direito Internacional Público. 15. ed. São Paulo: Renovar, 2004. v. 2.

MELLO, Sérgio Vieira de. História filosófica e História real: atualidade do pensamento político de Kant. In: MARCOVITCH, J. (Org.). Sérgio Vieira de Mello - pensamento e obra. São Paulo: Edusp / Saraiva, 2004.

MIALHE, Jorge L. Considerações Sobre a História do direito das relações internacionais. In: MIALHE, Jorge L. (Org.). Direito das relações internacionais - ensaios históricos e jurídicos. Campinas: Millenium, 2007.

Direito das Relações Internacionais - ensaios históricos e jurídicos. Campinas: Millenium, 2007.

MORE, Rodrigo Fernandes. Direito internacional do desarmamento: o Estado, a ONU e a paz. São Paulo: Editora Lex, 2007.

. Fundamentos das operações de paz das Nações Unidas e a questão de Timor Leste. Dissertação (Mestrado) - Faculdade de Direito, Universidade de São Paulo, São Paulo, 2002.

O desarmamento no sistema de segurança coletiva da ONU. 2005. Tese (Doutorado) - Faculdade de Direito, Universidade de São Paulo, São Paulo, 2002.

MÜLLER, Harald. Verification and Compliance. In: BOULDEN, James; THAKUR, Ramesh Chandra; WEISS, Thomas George (Coords.). The United Nations and Nuclear Orders. Tokyo: United Nations University, 2009. 
MURPHY, John F. Force and Arms. In: SCHACHTER, Oscar; JOYNER, Christopher. C. (Eds.). United Nations Legal Order. Cambridge: American Society of International Law, 1995. v. 1.

NARDIN, Terry. Lei, moralidade e as relações entre os Estados. Rio de Janeiro: Forense, 1987.

NETTO, Andrei. Fracassa acordo entre Rússia e EUA; Moscou nega ação militar na Ucrânia. O Estado de S. Paulo, São Paulo, 15 mar. 2014, A18.

NOUR, Soraya. À paz perpétua de Kant: filosofia do direito internacional e das relações internacionais. São Paulo: Martins Fontes, 2004.

OTT, David H. Public International Law in the Modern World. Londres: Pitman, 1987.

PADILHA, Tarcisio Meirelles. Energia nuclear em questão. 2. ed. Rio de Janeiro: Instituto Euvaldo Lodi, 1981.

PELLEGRINO, Charles. $O$ último trem de Hiroshima: os sobreviventes olham para trás. Tradução de Angélica Freitas. São Paulo: Leya, 2010.

PIOVESAN, Flávia. Direitos humanos e o Direito constitucional internacional. São Paulo: Max Limonad,1996.

PROTOCOLO adicional ao TNP: duas visões contrastantes. Folha de S. Paulo, São Paulo, 10 abr. 2010.

RAMINA, Larissa; CUNHA FILHO, Valter Fernandes da. Segurança internacional. Curitiba: Juruá, 2013.

RANGEL, Vicente Marotta. Direito e relações internacionais. 7. ed. São Paulo: RT, 2002. Prefácio à edição brasileira de VATTEL, Emmer de. O Direito das Gentes. Brasília: UnB, 2004.

REALE, Miguel. Lições preliminares de Direito. 24. ed. São Paulo: Saraiva, 1999.

REGEHR, Ernie. The Security Council and Nuclear Disarmament. In: BOULDEN, James; THAKUR, Ramesh Chandra; WEISS, Thomas George (Coords.). The United Nations and Nuclear Orders. Tokyo: United Nations University, 2009.

REUTER, Paul. Direito internacional público. Lisboa: Editorial Presença, 1981. 
REZEK, Francisco. Direito internacional público - curso elementar. 13. ed. São Paulo: Saraiva, 2011.

RILEY, Patrick. Will and Political Legitimacy. Cambridhe: Harvard University, 1982.

ROSAS, Allan; STENBÄCK, Pär. The Frontiers of International Humanitarian Law. Journal of Peace Research, v. 24, n. 3, Special Issue in Humanitarian Law of Armed Conflict, sep. 1987, Stage Publications.

ROUSSEAU, Jean-Jacques. Rousseau e as relações internacionais. Tradução de Sergio Bath. São Paulo: UnB/IPRI, 2003.

SAGAN, Scott D.; WALTZ, Kenneth N. The Spread of Nuclear Weapons: A Debate Renewed. New York: W.W. Norton, 2002.

SALIBA, Aziz Tuffi. Conselho de Segurança da ONU - sanções e limites jurídicos. Curitiba: Juruá, 2008.

SAMPAIO, Maria Feliciana Nunes Ortigão de. O Tratado de Proibição Completa dos Testes Nucleares (CTBT): Perspectivas para sua entrada em vigor e para a atuação diplomática brasileira. Brasília: Alexandre de Gusmão, 2012.

SANTOS COSTA, Alex Barbosa; ALMEIDA XAVIER, Matheus da Silva; FERNANDES, Raísa Oliveira. Argumentos favoráveis e desfavoráveis à assinatura do tratado de não proliferação de armas nucleares: a questão do Brasil. Cadernos de Estudos das Aulas do Lea, n. 1, v. 1, 2012. Disponível em: Swww.uesc.br/revistas/calea/ edicoes/rev1_artigo1.pdf>. Acesso em: 17 nov. 2014.

SASAKI, Tadataka Asking Young People to Create a Peaceful Country. In: An anthology of the experiences of Hiroshima Atomic Bomb victims. Shimonoseki: Yoshimura, 2010.

SEITENFUS, Ricardo; VENTURA, Deisy. Direito internacional público. 4. ed. Porto Alegre: Livraria do Advogado, 2006.

SIDHU, Waheguru Pal Singh. Dealing with Extra-NPT Actors and Non-State Actors. In: BOULDEN, James; THAKUR, Ramesh Chandra; WEISS, Thomas George (Coords.). The United Nations and Nuclear Orders. Tokyo: United Nations University, 2009.

SOARES, Guido Fernando Silva. As salvaguardas nos acordos nucleares. São Paulo: Bushatsky, 1977.

Curso de Direito Internacional Público. São Paulo: Atlas, 2002. 
Legitimidade de uma guerra preventiva? In: DUPAS, Gilberto; LAFER, Celso; SILVA, Carlos Eduardo Lins da (Orgs.). A nova configuração mundial do poder. São Paulo: Paz e Terra, 2008.

SOUSA CHEREM, Mônica Teresa Costa. Direito internacional humanitário. Curitiba: Juruá, 2003.

STODDART, Kristan. Losing an Empire and Finding a Role - Britain, the USA, NATO and Nuclear Weapons, 1964-70. Hampshire: Pallgrave Macmillan, 2012.

SWINAERSKI, Christophe. O direito internacional humanitário como sistema de proteção internacional da pessoa humana. In: VIEIRA, Oscar Vilhena (Coord.). Direitos humanos Estado de direito e a construção da paz. São Paulo: Quartier Latin, 2005.

THAKUR, Ramesh. Chemical Weapons and the Challenge of Weapons of Mass Destruction. In: THAKUR, Ramesh; HARU, Ere (Orgs.). The Chemical Weapons Convention. Tokyo: United Nations University, 2006.

Has the Good Become the Enemy of the Best? In: BOULDEN; James, THAKUR, Ramesh Chandra; WEISS, Thomas George (Coords.). The United Nations and Nuclear Orders. Tokyo: United Nations University, 2009.

War in Our Time - Reflections on Iraq, Terrorism and Weapons of Mass Destruction. Tokyo: United Nations University, 2007.

TRUYOL Y SERRA, Antonio. La sociedad internacional. Madri: Alianza Editorial, 1994.

VAlENTE, Manuel Monteiro Guedes. Direito Penal do Inimigo e o Terrorismo - O 'Progresso ao Retrocesso'. Coimbra: Almedina, 2010.

VATTEL, Emmer de. O Direito das Gentes. Brasília: Editora UnB, 2004.

VIEIRA, José Ribas. O Direito Internacional Público nos seus aspectos político-jurídicos no século XXI. In: MENEZES DIREITO, Carlos Alberto; CANÇADO TRINDADE, Antonio Augusto; ALVES PEREIRA, Antonio Celso (Orgs.). Novas perspectivas do Direito internacional contemporâneo - Estudos em homenagem ao Professor Celso D. de Albuquerque Mello. São Paulo: Renovar, 2008.

WALTZ, Kenneth N. O homem, o estado e a guerra - uma análise teórica. Tradução de Adail Ubirajara Sobral. São Paulo: Martins Fontes, 2004.

WEIL, Prosper. O direito internacional no pensamento judaico. Tradução de M. K. Nóbrega. São Paulo: Perspectiva, 1985. 
WIGHT, Martin. A política do poder. Tradução de Carlos Sérgio Duarte. Brasília: Editora UnB, 1985.

ZUCKERMAN, Solly. Nuclear Illusion and Reality. New York: The Viking, 1982.

\section{Lista de páginas eletrônicas citadas ao longo da dissertação}

IAEA (International Atomic Energy Agency). About us. Atoms for Peace. Disponível em: https://www.iaea.org/about. Acesso em: 13 dez. 2014.

BERTRAND RUSSELL'S Message to the Future. BBC Face-to-Face 1959. Enviado em 5 out. 2010. Disponível em: https://www.youtube.com/watch?v=O8h-xEuLfm8. Acesso em: 13 dez. 2014.

UNODA (United Nations Office for disarmament affairs). Treaty on the Non-Proliferation of Nuclear Weapons. Opened for signature at London, Moscow and Washington: 1 July 1968. Disponível em: http://disarmament.un.org/treaties/t/npt. Acesso em: 9 dez. 2014.

SALT I. Interim agreement between the United States of America and the Union of Soviet Socialist Republics on certain measures with respect to the limitation of strategic offensive arms. May 1972. Disponível em: http://www.nti.org/media/pdfs/aptsaltI.pdf?_=1316712383. Acesso em: 15 dez. 2014.

JORNAL NACIONAL: EUA queriam usar armas nucleares em 2002. Jornal (da Rede Globo) de 9 mar. 2002. Enviado em 1 jul. 2011. Disponível em: https://www.youtube.com/watch?v=THm0Pe-Bwjs. Acesso em: 24 nov. 2014.

U.S.A. Department of Defense and Department of Energy of United States of America. National Security and Nuclear Weapons in the 21st Century. Feb. 2008. Disponível em: http://www.defense.gov/news/nuclearweaponspolicy.pdf. Acesso em: 16 nov. 2014.

U.S.A. Seal of the President of the United States. National Security Strategy. May 2010. Disponível em: http://www.whitehouse.gov/sites/default/files/rss_viewer/national_security_strategy.pdf. Acesso em: 16 nov. 2014. 
GOV.UK. History. Past Prime Ministers. Harold Macmillan. (Written by James Jink.) Disponível em: <https://www.gov.uk/government/history/past-prime-ministers/haroldmacmillan> Acesso em: 8 nov. 2014.

UNIDOS PELOS DIREITOS HUMANOS. Disponível em: http://www.humanrights.com/pt/what-are-human-rights/universal-declaration-of-humanrights/articles-01-10.html. Acesso em: $18 \mathrm{dez} .2014$.

BRASIL. Ministério das Relações Exteriores. Blog Diplomacia Pública. Desarmamento, desenvolvimento e descolonização: 50 anos do "Discurso dos 3 Ds". 19 set. 2013. Disponível em: http://diplomaciapublica.itamaraty.gov.br/onu/41-o-discurso-dos-tres-ds. Acesso em: 5 dez. 2014.

UNITED NATIONS. Treaty Banning Nuclear Weapon Tests in the Atmosphere, in Outer Space and under Water. Opened for signature at London (L), Moscow (M) and Washington (W): 8 Aug. 1963. Disponível em: http://www.un.org/disarmament/WMD/Nuclear/pdf/Partial_Ban_Treaty.pdf. Acesso em: 17 dez. 2014.

Atomic energy for military purposes (The Smyth Report). By Henry De Wolf Smyth. 1st July, 1945. Disponível em: <http://www.atomicarchive.com/Docs/SmythReport/>. Acesso em: 8 Nov. 2014.

http://daccess-ddsny.un.org/doc/RESOLUTION/GEN/NR0/032/52/IMG/NR003252.pdf?OpenElement Acesso em: 9 dez. 2014.

UNITED NATIONS. Resolution 1653 (XVI). Disponível em: <http://daccess-ddsny.un.org/doc/RESOLUTION/GEN/NR0/167/06/IMG/NR016706.pdf?OpenElement>. Acesso em:2 Dez. 2014.

UNITED NATIONS. International Day against Nuclear Tests. 29 August. Disponível em: http://www.un.org/en/events/againstnucleartestsday/history.shtml\#a21. Acesso em: $21 \mathrm{dez}$. 2014.

UNITED NATIONS. Resolution 255 (1968). Question relating to measures to safeguard non-nuclear-weapon states parties to the treaty on the non-proliferation of nuclear weapons. Disponível em: http://www.un.org/en/ga/search/view_doc.asp?symbol=S/RES/255(1968). Acesso em: 6 dez. 2014. 
UNODA (United Nations Office for disarmament affairs). Treaty on the Non-Proliferation of Nuclear Weapons. Opened for signature at London, Moscow and Washington: 1 July 1968. Disponível em: http://disarmament.un.org/treaties/t/npt. Acesso em: 9 dez. 2014.

BUDAPEST MEMORANDUMS ON SECURITY ASSURANCES, 1994. Publicado no site do Council on Foreign Relations (New York), seção Primary Sources, em 5 dez. 1994. Disponível em: http://www.cfr.org/arms-control-disarmament-andnonproliferation/budapest-memorandums-security-assurances-1994/p32484. Acesso em: 5 dez. 2014.

ARAB league vows to drop out of npt if Israel admits it has nuclear weapons. Haaretz, Israel, Mar. 5, 2008. Disponível em: http://www.haaretz.com/news/arab-league-vows-todrop-out-of-npt-if-israel-admits-it-has-nuclear-weapons-1.240728. Acesso em: 20 nov. 2014.

Treze passos concretos em relação ao desarmamento nuclear Disponível em: <http://www.un.org/disarmament/WMD/Nuclear/pdf/finaldocs/2000\%20-\%20NY\% 20$\%$ 20NPT\%20Review\%20Conference\%20-\%20Final\%20Document\%20Parts\%20I\%20and \%20II.pdf>. Acesso em: 7 Dez. 2014.

IAEA. The statute of the IAEA. Disponível em: <http://www.iaea.org/about/statute\#a112>. Acesso em: 29 nov. 2014.

IAEA. The IAEA Mission Statement. Disponível em: <http://www.iaea.org/about/mission>. Acesso em: 30 nov. 2014

IAEA. Additional Protocols. Disponível em: <http://www.iaea.org/safeguards/documents/AP_status_list.pdf>. Acesso em: 9 dez. 2014.

EUROPEAN COMMUNITY. News Release. Entry into force of Euraton - IAEA Agreement. 17 Feb. 1977. Disponível em: 〈http://aei.pitt.edu/53692/1/NR_(77)_4.pdf>. Acesso em: 12 dez. 2014.

EUROPEAN UNION. Consolidated Version of the Treaty establishing the European Atomic Energy Community (2012/C, 327/01). Official Journal of the European Union, 26 Oct. 2012. Disponível em: <http://eur-lex.europa.eu/legalcontent/EN/TXT/PDF/?uri=CELEX:12012A/TXT\&from=EN>. Acesso em: 20 nov. 2014.

IAEA. Information Circular. Infcirc/395. 26 Nov. 1991. Agreement between the Republic of Argentina and Federative Republic of Brazil for the exclusively peaceful use of nuclear energy. Disponível em: <http://www.iaea.org/sites/default/files/publications/documents/infcircs/1991/infcirc0395. pdf>. Acesso em: 20 nov. 2014. 
<http://www.iaea.org/sites/default/files/publications/documents/infcircs/2000/infcirc 435.pdf>. Acesso em: 20 nov. 2014.

UNITED NATIONS. 2010 Review Conference of the Parties to the Treaty on the NonProliferation of Nuclear Weapons. NPT /CONF. 2010/25. Disponível em: <http://www.un.org/ga/search/view_doc.asp?symbol=NPT/CONF.2010/25>. Acesso em: 9 dez. 2014.

<http://www.iaea.org/sites/default/files/publications/documents/infcircs/1997/infcirc0540. pdf>. Acesso em: 27 nov. 2014.

UNODA. Brazil: Accession to Treaty on the Non-Proliferation of Nuclear Weapons $\begin{array}{lllll}\text { (NPT). } & 18 & \text { set. } & 1998 . & \text { Disponível }\end{array}$ em: $<$ http://disarmament.un.org/treaties/a/npt/brazil/acc/washington>. Acesso em: 15 nov. 2014.

PROTOCOLO adicional ao TNP: duas visões contrastantes. (Chamada de 12 abr. 2010 de Paulo Roberto de Almeida, autor do blog, que a seguir reproduz dois artigos do caderno Opinião, do jornal Folha de São Paulo, de 10 abr. 2010.) Disponível em: <http://diplomatizzando.blogspot.com.br/2010/04/2082-protocolo-adicional-ao-tnpduas.html>. Acesso em: 28 nov. 2014.

HEINRICH, Mark. Exclusive: ElBaradei says West won't meet Iran atom demand. Reuters edition US, 25 Nov. 2009. Disponível em: http://www.reuters.com/article/2009/11/25/usnuclear-elbaradei-idUSTRE5AO3DJ20091125>. Acesso em: 17 nov. 2014.

IAEA. Treaty for the Prohibition of Nuclear Weapons in Latin America (Tlatelolco Treaty). (Reproduced from United Nations document A/6663.) Disponível em: <http://www.iaea.org/Publications/Documents/Treaties/tlatelolco.html>. Acesso em: 17 nov. 2014.

IAEA. Tlatelolco Treaty A Trailblazer for Non-Proliferation. 14 Feb. 2007. Disponível em: <http://www.iaea.org/newscenter/news/tlatelolco-treaty-trailblazer-non-proliferation>. Acesso em: 18 nov. 2014.

UNITED NATIONS. 2437th plenary meeting, 11 Dec. 1975. Disponível em: <http://www.opanal.org/Docs/UN/UNAG30res3472i.pdf>. Acesso em: 7 dez. 2014.

UNODA. Additional Protocol I to the Treaty for the Prohibition of Nuclear Weapons in Latin America and the Caribbean. Protocol to the Treaty of Tlatelolco. Disponível em: <http://disarmament.un.org/treaties/t/tlateloco_p1>. Acesso em: 12 dez. 2014. 
$<$ http://www.iaea.org/sites/default/files/publications/documents/infcircs/1986/infcirc0331. pdf>. Acesso em: 18 nov. 2014.

〈http://www.iaea.org/sites/default/files/publications/documents/infcircs/1986/331a1.PDF> . Acesso em: 18 nov. 2014.

UNODA. Protocol 1 to the South Pacific Nuclear Free Zone Treaty. Protocol to the Treaty of Rarotonga. Opened for Signature: 1 Dec. 1986. Disponível em: <http://disarmament.un.org/treaties/t/rarotonga_p1>. Acesso em: 15 dez. 2014.

UNODA. Protocol 2 to the South Pacific Nuclear Free Zone Treaty. Protocol to the Treaty of Rarotonga. Opened for Signature: 1 Dec. 1986. Disponível em: <http://disarmament.un.org/treaties/t/rarotonga_p2>. Acesso em: 15 dez. 2014.

UNODA. Protocol 3 to the South Pacific Nuclear Free Zone Treaty. Protocol to the Treaty of Rarotonga. Opened for Signature: 1 Dec. 1986. Disponível em: <http://disarmament.un.org/treaties/t/rarotonga_p3>. Acesso em: 15 dez. 2014.

UNODA. Treaty on the Southeast Asia Nuclear Weapon-Free Zone. Opened for signature at Bangkok: 15 Dec. 1995.1 Disponível em: <http://disarmament.un.org/treaties/t/bangkok/text>. Acesso em: 18 nov. 2014.

UNODA. Protocol to The Treaty on Southeast Asia Nuclear Weapon-Free Zone. Protocol to the Bangkok Treaty. Disponível em: <http://disarmament.un.org/treaties/t/bangkok_protocol\#>. Acesso em: 18 nov. 2014.

UNODA. African Nuclear Weapon Free Zone Treaty. Treaty of Pelindaba. Signed at Cairo: $11 \quad$ April $1996 . \quad$ Disponível em: <http://disarmament.un.org/treaties/t/pelindaba/text>. Acesso em: 18 nov. 2014.

Resolução 1652 (XVI) da Assembleia Geral da ONU. Disponível em: <http://daccess-ddsny.un.org/doc/RESOLUTION/GEN/NR0/167/05/IMG/NR016705 .pdf?OpenElement>. Acesso em: 6 dez. 2014.

UNODA. Protocol I to the Pelindaba Treaty. Protocol to the Pelindaba Treaty. Início das assinaturas: 11 abr. 1996.2 Disponível em: <http://disarmament.un.org/treaties/t/pelindaba_1>. Acesso em: 18 nov. 2014.

UNODA. Treaty on a Nuclear-Weapon-Free Zone in Central Asia (CANWFZ). Opened for signature at Semipalatinsk: 8 Sep. 2006. Disponível em: <http://disarmament.un.org/treaties/t/canwfz/text>. Acesso em: 18 nov. 2014. 
UNODA. Protocol to the Treaty on a Nuclear-Weapon-Free Zone in Central Asia (CANWFZ). Início das assinaturas: 6 de maio de 2014. Disponível em: <http://disarmament.un.org/treaties/t/canwfz_protocol>. Acesso em: 18 nov. 2014.

COMPREHENSIVE NUCLEAR-TEST-BAN TREATY. Disponível em: <http://www.ctbto.org/fileadmin/content/treaty/treaty_text.pdf>. Acesso em: 20 nov. 2014.

COMPREHENSIVE NUCLEAR-TEST-BAN TREATY (CTBT). Opened for Signature: 24 Sep. 1996. Site: NTI (The Nuclear Threat Initiative). Disponível em: <http://www.nti.org/treaties-and-regimes/comprehensive-nuclear-test-ban-treaty-ctbt/>.

Acesso em: 7 dez. 2014.

CBTO. Status of Signature and Ratification. CTBTO preparatory commission for the comprehensive nuclear test-ban treaty organization. Disponível em: <http://www.ctbto.org/the-treaty/status-of-signature-and-ratification/>. Acesso em: $7 \mathrm{dez}$. 2014.

UNITED NATIONS. International convention for the suppression of acts of Nuclear terrorism, 2005. Disponível em: <https://treaties.un.org/doc/db/Terrorism/english-1815.pdf>. Acesso em: 20 nov. 2014.

UNITED NATIONS. General Assembly. 17 Dec. 1997. Measures to eliminate international terrorism. Disponível em: <http://www.un.org/documents/ga/res/51/a51r210.htm>. Acesso em: 20 nov. 2014.

UNITED NATIONS. International convention on the Suppression of Acts of Nuclear Terrorism. Opened for Signature: 14 Sep. 2005. Disponível em: <http://www.nti.org/treaties-and-regimes/international-convention-suppression-actsnuclear-terrorism/>. Acesso em: 7 dez. 2014.

UNITED NATIONS. UN Documents. Resolution adopted by the General Assembly. 13 April 2005. 59/290. International Convention for the Suppression of Acts of Nuclear terrorism. Disponível em: <http://www.un-documents.net/a59r290.htm>. Acesso em: 7 dez. 2014.

UNITED NATIONS. International convention for the suppression of acts of Nuclear terrorism, 2005. Disponível em: <https://treaties.un.org/doc/db/Terrorism/english-1815.pdf>. Acesso em: 20 nov. 2014.

ZENKO, Micah. A Nuclear Site is Breached. Washingtonpost.com. (Opinions), Washington, DC, 20 Dec. 2007. Disponível em: z<http://www.washingtonpost.com/wpdyn/content/article/2007/12/19/AR2007121901857.html>. Acesso em: 16 nov. 2014 
PIPES, Daniel. Não há diferenças entre o EIIS e o EIIL. (p/ National Review Online. 12 set. 2014.) Disponível em: <http://pt.danielpipes.org/14939/eiis-eiil>. Acesso em: 23 set. 2014.

NICHOLS, Michelle. Iraq tells U.N. that 'terrorist groups' seized nuclear materials. Reuters edition US, 9 Jul. 2004. Disponível em: <http://www.reuters.com/article/2014/07/09/usiraq-security-nuclear-idUSKBNOFE2KT20140709>. Acesso em: 4 dez. 2014.

IAEA. Information Circular. Text of the convention on the physical protection of nuclear material. $\quad 1979 . \quad$ Nov. Disponível em: <http://www.iaea.org/sites/default/files/infcirc274.pdf>. Acesso em: 10 nov. 2014.

IAEA. Convention on the physical protection of nuclear material. (Todos os documentos correlatos.) Disponível em: http://www.iaea.org/publications/documents/conventions/convention-physical-protectionnuclear-material>. Acesso em: 15 Nov. 2014.

THE INTERMEDIATE-RANGE NUCLEAR FORCES (INF) Treaty at a Glance. Press Contacts: Kelsey Davenport and Daryl Kimball. (Posted 23 May 2014.) Arms Control Association. Disponível em: <http://www.armscontrol.org/factsheets/INFtreaty>. Acesso em: 13 dez. 2014.

Armas nucleares voltam à pauta. DefesaNet, 31 out. 2014. Disponível em: <http://www.defesanet.com.br/nuclear/noticia/17287/Armas-nucleares-voltam-a-pauta/>. Acesso em: 30 nov. 2014.

Conferência do Desarmamento. 〈http://www.nti.org/glossary/\#conference-disarmament>. Acesso em: 10 dez. 2014.

UNITED NATIONS. General Assembly. 17 Nov. 1997. General and complete disarmament. Letter dated 31 October 1997 from the Chargé d'affaires of the a.i Permanent Mission of Costa Rica to the United Nations addressed to the Secretary General. Disponível em: <http://www.un.org/ga/search/view_doc.asp?symbol=A\%2FC.1\%2F52\%2F7\&Submit=Se arch \&Lang=E>. Acesso em: 7 dez. 2014.

<http://www.nti.org/treaties-and-regimes/proposed-nuclear-weapons-convention-nwc/>. Acesso em: 7 dez. 2014.

UNITED NATIONS. Resolution 154 (2004). Adopted by the Security Council at its 4956th meeting, on 28 April 2004. Disponível em: <http://www.un.org/en/ga/search/view_doc.asp?symbol=S/RES/1540\%20(2004)>. Acesso em: 20 nov. 2014. 
UNITED NATIONS. Resolution 1977 (2011). Adopted by the Security Council at its 6518th meeting, on 20 April 2011. Disponível em: <http://www.un.org/en/ga/search/view_doc.asp?symbol=S/RES/1977\%20(2011)> Acesso em: 27 dez. 2014.

UNITED NATIONS. Resolution 2055 (2012). Adopted by the Security Council at its 6795th meeting, on 29 June 2012. Disponível em: <http://www.securitycouncilreport.org/atf/cf/\%7B65BFCF9B-6D27-4E9C-8CD3CF6E4FF96FF9\%7D/s_res_2055.pdf>. Acesso em: 6 dez. 2014.

UNITED NATIONS. Resolution 1267 (1999). Adopted by the Security Council at its 4051st meeting on 15 October 1999. Disponível em: <http://www.un.org/ga/search/view_doc.asp?symbol=S/RES/1267(1999)>. Acesso em: 6 dez. 2014.

UNITED NATIONS. Resolution 1373 (2001). Adopted by the Security Council at its 4385th meeting, on 28 September 2001. Disponível em: http://daccess-ddsny.un.org/doc/UNDOC/GEN/N01/557/43/PDF/N0155743.pdf?OpenElement. Acesso em: 6 dez. 2014.

CRAIL, Peter. Swiss Destroy Key A.Q. Khan Evidence. Posted: Aug. 7, 2008. Arms Control Association. Disponível em: <http://www.armscontrol.org/act/2008_0708/Swiss>. Acesso em: 18 nov. 2014.

PLOEGER, Patrick; SOMSEN, Marnix; LAMP, Roan. Worldwide: Export Control And Sanctions. 15 Feb. 2013. Mondaq connecting knowledge and people (site), Disponível em: <http://www.mondaq.com/x/221856/Export+controls+Trade+Investment+Sanctions/Expor t+Control +And+Sanctions\&email_access=on>. Acesso em: 21/06/2013.

U.S. Department of defense. Proliferation Security Initiative. Disponível em: <http://www.defense.gov/home/features/2014/0814_psi/>. Acesso em: 7 dez. 2014.

ABOUT SIPRI (Stockholm International Peace Research Institute). Disponível em: <http://www.sipri.org/about>. Acesso em: 20 nov. 2014.

U.S. Department of State. Proliferation Security Initiative: Statement of Interdiction Principles. The White House, Washington, DC. Sep. 4, 2003. Disponível em: <http://www.state.gov/t/isn/c27726.htm>. Acesso em: 20 nov. 2014.

NTI (The Nuclear Threat Initiative). About NTI. Disponível em: <http://www.nti.org/about/>. Acesso em: 25 nov. 2014. 
NTI Nuclear Materials Security Index. Disponível em: <http://ntiindex.org/>. Acesso em: 25 nov. 2014.

NTI Nuclear Materials Security Index. Video: Threat of Nuclear Terrorism. 7 Jan. 2014. Disponível em: <http://ntiindex.org/news-items/threat-nuclear-terrorism/>. Acesso em: 25 nov. 2014.

INTERNATIONAL COURT OF JUSTICE. Legality of the threat or use of nuclear weapons. Advisory opinion of 8 July 1996. Disponível em: <http://www.icjcij.org/docket/files/95/7495.pdf>. Acesso em: 3 jul. 2013.

UNITED NATIONS. General Assembly. 15 December 1994. $49 / 75$ General and complete disarmament. Disponível em: http://www.un.org/documents/ga/res/49/a49r075.htm. Acesso em: 12 nov. 2014.

INTERNATIONAL COURT OF JUSTICE. Déclaration de M. Bedjaoui. Ménace ou emploi d'armes nucléaires. Disponível em: <http://www.icjcij.org/docket/files/95/7499.pdf>. Acesso em: 3 jul. 2013.

INTERNATIONAL COURT OF JUSTICE. Dissenting opinion of Vice-President Schwebel. Threat or use of nuclear weapons (Ménace ou emploi d'armes nucléaires). Disponível em: <http://www.icj-cij.org/docket/files/95/7515.pdf>. Acesso em: 3 jul. 2013.

INTERNATIONAL COURT OF JUSTICE. Note Verbale dated 19 June 1995 from the Embassy of Mexico, together with Written Statement of the Government of Mexico. Disponível em: <http://www.icj-cij.org/docket/files/95/8694.pdf〉. Acesso em: 3 jul. 2013.

INTERNATIONAL COURT OF JUSTICE. Letter dated 16 June -1995 from the Minister for Foreign Affairs of Bosnia and Herzegovina. Disponível em: <http://www.icjcij.org/docket/files/95/8708.pdf>. Acesso em: 15 jul. 2013.

INTERNATIONAL COURT OF JUSTICE. Letter dated 19 June 1995 from the Ambassador of the Russian Federation, together with Written Comments of the Government of the Russian Federation. Disponível em: <http://www.icjcij.org/docket/files/95/8796.pdf>. Acesso em: 3 jul. 2013.

INTERNATIONAL COURT OF JUSTICE. Letter dated 18 May 1995 from the Permanent Representative of the Democratic People's Republic of Korea to the United Nations. Disponível em: http://www.icj-cij.org/docket/files/95/8668.pdf. Acesso em: 1 jun. 2013.

INTERNATIONAL COURT OF JUSTICE. Note Verbale dated 19 June 1995 from the Embassy of the lslamic Republic of Iran, together with Written Statement of the 
Government of the Islamic Republic of Iran. Disponível em: http://www.icjcij.org/docket/files/95/8678.pdf Acesso em: 1 jun. 2013.

RÚSSIA diz aceitar ação militar na Síria se uso de armas químicas for provado. Folha de São Paulo. 4 set. 2013. Disponível em: <http://www1.folha.uol.com.br/mundo/2013/09/1336646-russia-diz-aceitar-acao-militarna-siria-se-uso-de-armas-quimicas-for-provado.shtml>. Acesso em: 4 set. 2013.

IAEA. Information circular. Agreed framework of 21 October 1994 between the United States of America and the Democratic People's Republic of Korea. Disponível em: $<$ http://www.iaea.org/sites/default/files/publications/documents/infcircs/1994/infcirc457.p df>. Acesso em: 17 nov. 2014.

<http://news.bbc.co.uk/2/mobile/asiapacific/7265679.stm>, Acesso em: 17 nov. 2014.

UNITED NATIONS. Resolution 1718 (2006). Adopted by the Security Council at its 5551st meeting, on14 October 2006. Disponível em: <http://www.un.org/ga/search/view_doc.asp?symbol=S/RES/1718\%20(2006)>. Acesso em: 6 dez. 2014.

UNITED NATIONS. Resolution 1887 (2009). Adopted by the Security Council at its 6191st meeting, on 24 September 2009. Disponível em: <http://www.un.org/en/ga/search/view_doc.asp?symbol=S/RES/1887(2009)>. Acesso em: 6 dez. 2014.

COREIA DO NORTE é acusada de estar preparando teste nuclear. BBC Brasil. 8 abr. 2013. Disponível em: <http://www.bbc.co.uk/portuguese/ultimas_noticias/2013/04/130408_coreia_ataque_bg_rn $>$. Acesso em: 4 dez. 2014.

UNITED NATIONS. Resolution 487 (1981). Adopted by the Security Council at its 2288st meeting, on 19 June $1981 . \quad$ Disponível em: <http://unispal.un.org/unispal.nsf/d744b47860e5c97e85256c40005d01d6/6c57312cc8bd93 ca852560df00653995>. Acesso em: 7 dez. 2014.

UNITED NATIONS. Statement by His Excellency Dr. Mahmoud Ahmadinejad President of the Islamic Republic of Iran before the 2010 Review Conference of the Parties to the Treaty on the Non-Proliferation of Nuclear weapons (NPT) United Nations, New York, 3 May 2010. Disponível em: <http://www.un.org/en/conf/npt/2010/statements/pdf/iran_en.pdf>. Acesso em: 19 nov. 2014. 
UNIDIR. (United Nations Institute for Disarmament Research.) Disponível em: <http://www.unidir.org/>. Acesso em: 20 dez. 2014.

THIRD Session of The Preparatory Committee (PrepCom) for the 2015 Review Conference of the Parties to the Treaty on the Non-Proliferation of Nuclear Weapons (NPT). 28 April - 09 May 2014, New York. Disponível em: http://www.un.org/disarmament/WMD/Nuclear/NPT2015/PrepCom2014/ Acesso em: 17 nov. 2014. 